\title{
Christ in the Margins: Confronting Racism through the (Written) Word in Post-Civil War America
}

\author{
Cara L. Snider
}

Follow this and additional works at: https://researchrepository.wvu.edu/etd

\section{Recommended Citation}

Snider, Cara L., "Christ in the Margins: Confronting Racism through the (Written) Word in Post-Civil War America" (2015). Graduate Theses, Dissertations, and Problem Reports. 6679.

https://researchrepository.wvu.edu/etd/6679

This Dissertation is protected by copyright and/or related rights. It has been brought to you by the The Research Repository @ WVU with permission from the rights-holder(s). You are free to use this Dissertation in any way that is permitted by the copyright and related rights legislation that applies to your use. For other uses you must obtain permission from the rights-holder(s) directly, unless additional rights are indicated by a Creative Commons license in the record and/ or on the work itself. This Dissertation has been accepted for inclusion in WVU Graduate Theses, Dissertations, and Problem Reports collection by an authorized administrator of The Research Repository @ WVU.

For more information, please contact researchrepository@mail.wvu.edu. 


\title{
Christ in the Margins: \\ Confronting Racism through the (Written) Word \\ in Post-Civil War America
}

\author{
Cara L. Snider \\ Dissertation submitted to \\ the Eberly College of Arts \& Sciences \\ at West Virginia University \\ in partial fulfillment of the requirements \\ for the degree of \\ Doctor of Philosophy \\ in \\ English
}
Timothy Sweet, Ph.D., Chair
John R. Ernest, Ph.D.
Cari Carpenter, Ph.D.
Michael Germana, Ph.D.
Edward J. Blum, Ph.D.

Morgantown, WV
2015

Keywords: race reform, postbellum fiction, Mark Twain, Charles Sheldon, Frances Harper, Sutton Griggs

Copyright 2015 Cara L. Snider 


\section{Abstract: \\ Christ in the Margins: Confronting Racism through the (Written) Word in Post-Civil War America}

\section{Cara L. Snider}

This dissertation examines fictional texts of the late nineteenth century in order to recover the response of progressive Christian writers facing a growing tide of racial violence, injustice, and segregation in the postbellum decades. By investigating the works of Mark Twain, Charles Sheldon, Frances Harper, and Sutton Griggs, I argue that we gain access to a cadre of writers who sought to translate emerging strains of New Theology into practical means of race reform. They regarded their novels as sermons to the masses and saw writing as a sacred practice of communicating the Word to fellow believers; and their brand of Christian Liberalism was rooted in Incarnational theology, prized the humanity of Christ, insisted on a social gospel, and exhorted others to adopt a self-sacrificial and costly form of discipleship.

Throughout the late nineteenth century both white and black ministers turned toward storytelling in the pulpit, and so the era's prolific writers paralleled this movement by embracing homiletic realism in literature. The resulting narratives were often bestsellers that captivated wide audiences even while exposing the false process of racial categorization, revealing race as a social construct, and depicting tangible acts of social Christianity among disenfranchised and violently oppressed African-American communities. By returning to these narratives, then, we are able to reconstruct the period of race reform in the postbellum years-one that bridges Protestant abolitionist zeal with progressive Civil Rights activism - and we draw closer to a more complex and accurate understanding of America's racial and theological past. 


\section{Acknowledgements}

Take not, oh Lord, our literal sense. Lord, in Thy great

Unbroken speech our limping metaphor translate.

-- C. S. Lewis ${ }^{1}$

Our lives are built on stories, and scholarship is a form of storytelling that values the past in an effort to make it meaningful to the present. In the course of completing this project I've come to value the many family members, friends, mentors, professors, colleagues, and students who have shared my personal and scholarly story. You've listened to me talk endlessly about nineteenth-century literature and race (whether you wanted to hear it or not), you asked questions that grounded my argument in significant and detailed ways, and you've sustained me with your encouragement when the road seemed far, far too long. The following pages are dedicated to our collective, blessed story.

This project is very much a testament to the guidance of Dr. John Ernest, whose courses in nineteenth-century literature and critical race theory exposed me to stories both captivating and horrifying. Our readings and discussions through the years re-oriented my conception of American literature at its core, taught me what kinds of questions to ask, and reinforced the importance of a nuanced understanding of history, race, and theology. Above all, John taught me to truly listen to the voices of the past and to do so with reverence. I am grateful for his close reading of my work, for his generous encouragement throughout this project, and for his commitment to leading by example as a scholar, mentor, professor, and friend. Quite simply I am not the same scholar or person I was before I began working with you, John. Thank you.

Also while at West Virginia University, I benefited from the careful and sincere guidance

\footnotetext{
${ }^{1}$ C.S. Lewis, "Footnote to All Prayers." The Cambridge Companion to C.S. Lewis. Ed. Robert MacSwain and Michael Ward. New York: Cambridge University Press, 2010. 300.
} 
of Dr. Timothy Sweet whose early American literature courses honed my research and writing ability, who taught me always to keep a skeptical audience in mind (especially when writing about theology), and who rejoiced with me as my project came together. Tim, your feedback on my early drafts and your enthusiasm for my work has been such an encouragement during my time away from WVU. Bring on the hooding!

I would like also to thank the other members of my dissertation committee-Dr. Cari Carpenter, Dr. Michael Germana, and Dr. Edward J. Blum—-for their careful reading of this project, for the ideas and connections their comments generated, and for the resources they suggested. You've have given me much to pursue in the coming year. I'll be in touch.

Other members of the WVU community who were integral the process of this degree and project include professors Gwen Bergner, Tom Sura, and Lisa Weihman; graduate directors Dennis Allen and Adam Komisaruk (thanks for keeping everything on track!); English Department staff members Amanda Tustin, Michelle Marshall, and Mary Vasquez; and my fellow graduate student colleagues, in particular Joel and Emily Christenson, Jake Ivey, Lauren Thompson, Ginny Young, Courtney Novosat, Andrea Bebell, and Kwabena Opoku-Agyemang. To the esteemed Copper Beech crew, David Goldberg and Joe Rizzo: I would never have made it through without our endless political debates, family dinners, and "award" ceremonies. And to Yvonne Swartz, whose moved from colleague status to friend-for-life: I am grateful for your generosity, your family who always welcomes me, and your ability to produce amazing and homemade food while working a hundred hours a week.

While dissertating, I spent the last two years away from WVU as a full-time lecturer at Shepherd University, and there my colleagues in the Department of English and Modern Languages quickly became like family. They encouraged me to press on in my writing, supplied 
me with countless cups of coffee and numerous home-baked goods, and lavished me with celebration when I finished. In particular I wish heaping blessings upon Drs. Heidi Hanrahan, Carrie Messenger, Christy Wenger, Jon Elmore, Betty Ellzey, Tim Nixon, Jim Lewin, Mark Cantrell, Chad Loewen-Schmidt, Denis Berenschodt, Rachel Krantz, and Eva-Maria SuárezBüdenbender. To Dr. Dow Benedict, Shepherd's Dean of the College of Arts and Humanities: Thanks for always asking, "How's the diss coming?” I promised you I'd finish! And finally to Brenda Feltner, our department's resident magician, professional whiz, and house mother: you're the best! I'll think of you all every time I look at "Dr. Dog."

As anyone who has completed a doctoral degree knows, it is the friendships along the way that sustain you. I've been fortunate to add some wonderful characters to my story over the years, and my cup overflows with their generosity, love, support, laughter, and conversation. My life is regularly shaped by my companions for life-Julie Hasson, Jill Hasson, and Amanda Downin — who remind me not to take myself too seriously, to always "count down" to the good times, to live through the questions into the answers, and to revel in the quiet moments... at least until the next outburst of laughter. Then there are my former college roommates and kindred spirits Stacey Shcolnik, Gina Henker, who are my fellow sojourners through the difficult questions and my adopted sisters for life. So many of our conversations live on in this project. There are also several former professor friends from my undergraduate years who have stayed in touch and who provided me a foundation in literary, theological, and philosophical study: Drs. Don Deardorff, Dave Mills, Kevin Heath, and Jeff Cook. I am indebted, too, to my University of New Hampshire crew_fellow graduate student friends who came into my life when I was a Masters student and (thankfully) never left: Meagan Rodgers, Abby Knoblauch, Nicola Imbrascio, Chrissy Healey, Beth Cooper, Jeff Ringer, Mike Garcia, Mike and Courtney 
DePalma, Charmaine Dull, Steve and Beth Simpson, Yassmeen Abdulhamid, and Rachael Berkey. Our years together were something special, indeed.

Of course, my family has borne the weight of this project for many years, and I thank them for helping me carry this load, praying me through the struggles, and rejoicing when I rejoiced. To my siblings and their families—Keith, Diana, Brian, Susan, Dave, Nathaniel, Alex, William, Sammy, Ben, and Austin: thank you for loving me in tangible ways and celebrating each milestone along this long journey. I respect your wisdom, marvel at your kindnesses, and consider it an honor to travel this life with you as my family. Above all, I have been fortunate to have parents who are truly my friends and models of selfless love and enduring faith. There were countless hours while working on this project that you reassured me, rushed to my aid, and provided necessary distractions with home cooking, Dick Van Dyke reruns, and basketball games. In my early days you taught me the foundational principles that still guide my life: to love God and love others, no matter what. Thank you for this eternal lesson. It is, after all, the greatest gift.

I feel I must also devote a few lines to the illiterate, furry members of my family, who have been by my side (well, ankles...) ever since the start my graduate school life. Thank you Jacques and Gus for logging countless miles as I walked to work through ideas, for lying at my feet as I typed away, and for running to greet me every single day. You're my boys.

Finally, to the most tireless champion of this project-my partner Brandon. Meeting you was the most rewarding part of going to WVU all those years ago, and you've kept me laughing, kept me grounded, and kept me moving forward ever since. Most importantly, you have evidenced your love by never giving up on me, even when I had, and this dissertation is dedicated to you. You astound me with your insights and compassion every day, to which I 
reply, “Thank yeeeww!" Now, let's go West and write the next chapter! 


\section{Table of Contents}

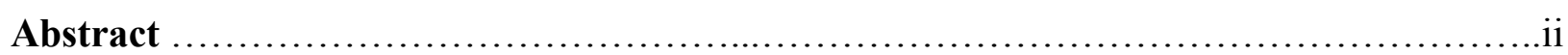

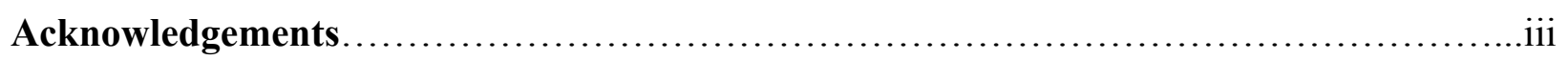

Introduction: "I Love to Tell the Story" ..............................................

\section{Chapter 1: The Gospel of Mark:}

Twain on Race, Liberal Theology, and the Homiletic Story..............................16

\section{Chapter 2: "The Christ In Us":}

Charles Sheldon's Social Gospel for Racial Redemption

Chapter 3: Reading and Writing the Black Nazareth:

Blood Identity and Bodies as Sacred Texts in Frances Harper's Iola Leroy.....

Chapter 4: To Follow the "Suffering Savior":

Sutton E. Griggs, God's Kingdom, and the Struggle of Race Reform....................... 170

Conclusion: Still Searching for the "Divine Spark"

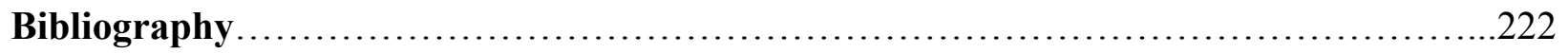




\title{
Introduction: "I Love to Tell the Story"1
}

\author{
"Why shall not our special symbol be Jesus of Nazareth- \\ not as the second person of a divine Trinity, not as an \\ Atoning Sacrifice, not as a superhuman being, but as a man, \\ in whom, I repeat, the divine possibilities of our nature have \\ been realized as never before nor since?" \\ -Rev. William Furness ${ }^{2}$
}

If the Civil War is best regarded as a "theological crisis," the latter decades of the nineteenth century were its culmination. ${ }^{3}$ The nation had been ravaged by the conflict, and four million new citizens were in need of education and jobs, social protection and legal representation. Believers from a host of denominations and doctrinal backgrounds responded to the War's upheaval by examining their faith for practical, social teachings, and there they found and embraced the person of Christ, touting his message for society's salvation. On the whole, antebellum theological debate had maintained a focus on God's Providence over earthly affairs, the inerrancy and accessibility of Scripture, and the transcendence of the Father who had forged a special covenant relationship with his chosen nation. But after the War, writers, theologians, and laypersons grew weary of discerning God's Providential plan and many turned instead to the fiercely practical gospel of Jesus Christ. The transition is everywhere apparent in religious periodicals of the era: a writer for The Christian Index lauded the "Practical Savior," social reformer Anna L. Dawes hailed “Jesus Christ's Method of Social Regeneration,” the Rev. William H. Furness celebrated "Jesus, the Only," and Presbyterian minister A.S. Weber penned

1 This phrase is taken from the Methodist hymn of the same title, written by English evangelist Katherine Hankey in 1866. It was part of a series of writings by Hankey, who composed a long poem to tell the life of Jesus. Excerpts from the poem were set to music by William G. Fisher in 1867, and the hymn was published in the Methodist Episcopal Book Room in Philadelphia. The famous refrain states, "I love to tell the story, / "twill be my theme in glory. / To tell the old, old story / of Jesus and His love." See C. Michael Hawn, "History of Hymns: 'I Love to Tell the Story," United Methodist Church Discipleship Ministries. Web. 2015. 2 William Henry Furness. “Jesus of Nazareth.” The Unitarian Review 32.1 (July 1889):47. 47.

3 Mark A. Noll, The Civil War as Theological Crisis. Chapel Hill: University of North Carolina, 2006. 
an article titled, "Jesus Christ, the Greatest Reformer.",

But this theological pivot toward Jesus's reformist gospel also proved to be transformational and transitional for Christian reform fiction of the late nineteenth century. From about 1870 to the turn of the century, a chorus of Christian writers responded to a variety of social ills by transforming Protestantism through the Person and Example of Jesus, and they worked in their literature to transition liberal theology into an accessible and compelling social gospel. More specifically, what united these writers was their embrace of emerging theological teachings regarding Christ's humanity, higher criticism of Scripture, and the radical notion of what they saw as "costly" discipleship. To them, God was no longer a distant, paternal being, but the Incarnate One who had suffered as an outcast and brought a gospel devoted to love and justice on earth, as well as eternal redemption. Exhortations from liberal Christian ministers, "New Theology" seminaries, and progressive religious periodicals filtered into reformist fiction and soon popular literature took on the role of sermons to the masses. Everywhere publishing houses produced novels of Christian reformist fiction-from successful writers like Charles Sheldon's In His Steps (1896) to Elizabeth Stuart Phelps's Gates Ajar (1868) and The Silent Partner (1871), Washington Gladden's The Christian League of Connecticut (1883), Albion Tourgée's Murvale Eastman, Christian Socialist (1890), William T. Stead's If Christ Came to Chicago (1894), and Charles Gordon's Black Rock (1898). And then there were more provocatively titled novels that weren't as popular: Milford W. Howard's If Christ Came to

4 “A Practical Saviour." Christian Index 65.52 (24 Dec. 1885). 8.; Anna L. Dawes, "Jesus Christ's Method of Social Regeneration." The Independent. 42.2187 (30. Oct. 1890):3.; William H. Furness, "Jesus, the Only.” The Unitarian Review and Religious Magazine. 4.1 (July 1875):1.; A.S. Weber, "Jesus Christ, the Greatest Reformer." Reformed Quarterly Review. 3 (July 1892):389. Weber explicitly connected the issue of slavery with Christ's salvation, writing, "When Jesus was born vast multitudes were in the bondage of slavery.... Behold now what Christ has wrought! The legal and social status of these multitudes has been changed. The lofty wall, which seemed strong enough for all ages, to separate the classes, has yielded to the leveling, equalizing power of the Gospel" (389). 
Congress (1894), Isaac G. Reed Jr.'s From Heaven to New York (1894), Edward Everett Hale's If Jesus Came to Boston (1895), Olla P. Toph's Lazarus (1895), and Cortland Myers's Would Christ Belong to a Labor Union? (1900).

For a number of progressive Christian reformist writers, however, the issue of race and the legacy of slavery cast a deep shadow over any discussion of Jesus's practical message of social redemption. To these writers, very much on the margins of American culture and American Protestantism, the story of Christ's liberation had been re-enacted in the nineteenth century but certainly was not complete. If Jesus had set the "captives" free with the Civil War, they reasoned, it was the duty of all Christians to ensure that black citizens were treated with compassion, defended as equals, and elevated through self-sacrificial concern for "the least of these" who Christ had welcomed into his kingdom. This message united black and white reform writers in a conversation over how to proceed in a (supposedly) Christian society and, to them, writing on behalf of racial justice was sacred work. The unjust American landscape had become a site for conscious and ardent ministry, and, as Frances Harper wrote, "if any lover of Christ wants a field for civilizing work, here is a field." ${ }^{5}$

In many ways race was at the center of postbellum life, and after the War racial exclusion and preservation of whiteness became the basis for legal declarations, educational policies, social customs, and even religious practice. Without the institution of slavery, social hierarchies of the past became much more ambiguous and "race had to be authenticated on a daily basis between strangers in a modernizing, geographically fluid South." ${ }^{\circ 6}$ Indeed, nineteenth-century discourse reflected a growing fear among whites that "blackness was in danger of becoming whiteness"

5 Harper, qtd. in Foster, 142. Frances Smith Foster. A Brighter Coming Day: A Frances Ellen Watkins Harper Reader. Ed. Frances Smith Foster. New York: City University of New York, 1990.

6 Mark M. Smith, How Race is Made: Slavery, Segregation, and the Senses. Chapel Hill: University of North Carolina, 2006. 7. 
because as 'the number of visually ambiguous 'black' people increased (the great age of 'passing' was $1880-1925) \ldots$ sight became ever less reliable as an authenticator of racial identity. ${ }^{, 7}$ Hoping to make racial classifications tangible and Segregation complete, southern states began banning interracial marriage as early as 1867 , Black Codes drew color lines between black and white bodies in public spaces, the Klan and vigilante groups attacked black men and women with legal impunity, the Supreme Court declared the 1875 Civil Rights Act unconstitutional, and "legal, state-sanctioned segregation triumphed in the 1890s," culminating in the Plessy v. Ferguson decision of $1896 .{ }^{8}$ Reformist minded writers had to navigate this chaotic, hostile, and even violent landscape to challenge the very basis of racial categorization. For white, liberal Protestants, the challenge of bringing Christ's gospel to bear on racial policy was a formidable one; for African-American writers, such attempts meant risking personal safety. In the end, both agreed that the nation needed what Charles Sheldon called "a Christ for the common people," one who "bids us all recognize the Brotherhood of the race, who bids us throw open this room to all. ${ }^{9}$

Amid this fraught racial discourse, literature became central, not ancillary, to race reform endeavors and writing itself was a sacred act connected to the mission of the Practical Savior. For progressive and evangelical believers alike, storytelling's theological significance in the late

7 Ibid, 7.

8 While the Black Codes were dismantled by Congress in 1867, Smith reminds us that "Congress could not erase the cultural imperatives that gave rise to the Codes in the first place. Unspoken protocols of racial segregation prevailed during Reconstruction. It seemed to matter little who had political control in these years, for even with Republicans and black voters in control, schools were segregated and the races increasingly kept apart" (51). Additionally, while the Plessy v. Ferguson ruling did not come til 1896, many states had already passed laws mandating segregation between black- and white-skinned citizens, such as Louisiana, which passed a law in 1890 that segregated railroad cars (72-73). In the case of Plessy v. Ferguson, there was also a good deal of "blood" talk, which parallels Harper's own writings, but cannot be detailed (due to length) here. For more, see Smith, 72-76.

9 Charles Sheldon, qtd. in Miller, 23. Miller, Timothy. Following in His Steps: A Biography of Charles M. Sheldon. Knoxville: University of Tennessee, 1987. 
nineteenth century echoed Jesus's practice of speaking in parables in his earthly ministry. And, further, the very power of language was rooted in a theological reckoning that harkened back to the ultimate referent- the Word of God, Christ himself. This typological link to biblical storytelling existed much earlier in American literature, of course, but its reformist angle-with Christ at the center-was certainly unique to the late nineteenth century. Even Harriet Beecher Stowe commented on the phenomenon, writing, "“'Hath any one in our day, as in St. Paul's, a psalm, a doctrine, a tongue, a revelation, an interpretation - forthwith he wraps it up in a serial story, and presents it to the public.... We have... High Church and Low Church and no Church, contending with each other in serial stories, where each side converts the other, according to the faith of the narrator." ${ }^{10}$ In regard to the narrative of American racial policy, writers knew that while the Civil War may have been the battleground against slavery, the war against racist ideology would be fought out in the journals, novels, and newspapers for many years to come. In this era, too, popular ministers like Dwight Moody, Phillip Brooks, and T. DeWitt Talmage pioneered the use of storytelling in the pulpit, and so literary storytellers created their own "pulpits" through publication and circulated carefully-crafted tales of Social Christianity and racial reform narratives. ${ }^{11}$ Writing —-the development of story—was theology, as it allowed a reformist-minded believer to prompt fellow citizens toward correct action; and in the case of race reformers, the hope was that readers would reject racial violence, uphold the rights of citizenship for black Americans, mend inter-denominational squabbling over the "color line," and unite as a powerful force—-black and white together-for brotherhood and social justice. Literature was the kernel of revolution, writers believed: a good story, a strong narrative turn could provoke

10 Harriet Beecher Stowe, My Wife and I. 1871. New York: Riverside, 1967. xi.

11 David S. Reynolds, "From Doctrine to Narrative: The Rise of Pulpit Storytelling in America." American Quarterly 32.5 (1980): 479-498. 480. 
activism on behalf of racial equality, just as it had in the fervid days of abolition. In ways that current literary studies has yet to appreciate, these late nineteenth century works of fiction provide a bridge between biblically-based anti-slavery literature of the antebellum period and the religiously-influenced Social Gospel or Civil Rights fiction of the twentieth century. By acknowledging the ways in which race was at the core of American society, many of these progressive Christian writers believed meaningful change could only come through interracial efforts at a practical gospel, and their texts provide a testimony to the growing spirit of race reform work that became more tangible in the early twentieth century, in places like New York, Chicago, and Atlanta. While Social Gospel race reformers such as Reverdy Ransom, Ida B. Wells-Barnett, and Nannie Boroughs gained national attention in the twentieth century, late nineteenth century writers were already laying the foundation by examining legal and religiously sanctioned white supremacy, the social construction of race, and the need for better schooling, employment, political representation, and material conditions.

But while vibrant, activist storytelling and liberal theology merged to create some of the most progressive literature of the nineteenth century, current literary scholarship on the era is shockingly anemic. There are exceptions, of course, such as the wonderful work being done by Harold Bush, John Ernest, Frances Smith Foster, and Carla Peterson; but on the whole late nineteenth-century writers are either ignored by literary scholars or, worse, the works of these decades are regarded as case studies in isolation, viewed narrowly as genre types (realism, local color), or generally discussed without the necessary nuance of racial and religious context. As I illustrate in subsequent chapters, literary scholars, too, are guilty of discounting "popular" works from the late nineteenth century, according to ill-defined (and often arbitrary) standards of quality. This unfortunate neglect means that writers from these decades are viewed singly and 
not part of a larger, fervid social movement; and white and black writers rarely are examined in conversation with one another, leading to a false "color line" in literary scholarship. Some recent scholars have investigated connections between race and American realist style—such as Henry Wonham's Playing the Races: Ethnic Caricature and American Literary Realism and Kenneth Warren's Black and White Strangers: Race and American Literary Realism. But Wonham focuses on visual depictions of race in comparison with literature - such as representations of minstrelsy—and while Warren brings together Mark Twain, George Washington Cable, W.E.B. DuBois, Albion Tourgee, Harriet Beecher Stowe, and Henry James, he never mentions any religious underpinnings for race reform, nor does he discuss the theological aspects of these writers' texts. As Claudia Stokes writes, "Religious novels occupied a central role in the literary late century, but have seldom received commensurate acknowledgement in the era's literary history, and omission that likely derives from a confluence of causes, foremost among them their marked divergence from the neat academic categories of periodization.." ${ }^{\prime 2}$ Ultimately, traditional generic labels fail to capture these public exchanges of ideas and have worked only to flatten, rather than enliven, scholarly inquiry.

What is necessary for literary studies, then, is an understanding of the confluence of race, liberal Christianity and popular storytelling that existed in the postbellum years, and a respect for the literature these discussions produced. It is a rich, diverse, and compelling catalog, indeed. To sort through the disorienting landscape of the late nineteenth century, white and black writers turned to literature to depict and interrogate the processes of racial codification and disenfranchisement. Into their fictional narratives, poems, pamphlets, sermons, columns, and articles they questioned the enactment of racist legal structures (Jim Crow laws, the Black Codes, 1940. Ed. Priscilla Wald and Michael A. Elliott. Vol. 6. Oxford: Oxford U.P., 2014. 168-184. 171. 
vigilante activities), the theological sanction of white supremacy, and the manipulation of the criminal justice system. They expertly blended genres to subvert traditional narrative patterns, to capitalize on realism's potential for activism, and blended sermonic storytelling from the pulpit with sentimentalism and even dystopian forms. In their novels, historic events are layered over with biblical allusion, and narrators, in turn, take on prescriptive voices or act as unstable, suspect guides through a linear narrative no longer possible amid such profound social chaos. Above all, these writers composed narratives to inspire tangible action on the part of practical Christianity and, as Sutton E. Griggs stated it, they encouraged their readers to "rally around the page," insisting that the reformist power of literature could be a fierce conduit in and catalyst for the struggle against racism. ${ }^{13}$ It is not surprising, of course, that individuals would turn to the power of narrative, both for its stabilizing impact and for its ability to envision changesomething Paul Ricoeur calls "the dialectic of sedimentation and innovation." ${ }^{, 14}$ Storytelling, in Ricoeur's characterization, permits writer and audience to return to (fragmented) traditions in a way that provides "sedimentation," or a firm grounding, for future "innovation." Indeed, a flourish of literature emerged in the 1880s and 1890s, narrating a spectrum of reformist perspectives each scaffolded around foundational principles of freedom, citizenship, and Christianity.

What follows in this study, then, is a return to the chaotic decades of the 1880 s and 1890 s to examine a chorus of reformist, theologically progressive narratives of prolific and often bestselling writers-Mark Twain, Charles M. Sheldon, Frances E.W. Harper, and Sutton E. Griggs. While variegated in their approach to theology and racial reform, together these writers represent

13 Sutton E. Griggs, Life's Demands; or, According to Law. Memphis, TN: National Public Welfare League, 1916. 33.

14 Paul Riceour, Figuring the Sacred: Religion, Narrative, and Imagination. Translated by David Pellauer. Ed. Mark I. Wallace. Minneapolis: Fortress Press, 1995. 240. 
the larger turn toward practical Christianity that took place after the failure of Reconstruction and before the implementation of a more secular Social Gospel in the early twentieth century. Together, too, they exemplify the typological figure of the biblical prophet—voices crying in the wilderness, who believed that the sacred could transform the profane and that the nation's shared Christian past could still speak to contemporary racial divisions. In significant ways, these writers converse with one another through themes of sacrificial Christianity, religious practice based on the person of Jesus, and the necessity of interracial reform work: Twain's attack on American Christianity and insistence on a doctrine of imitatio Christi find life in Sheldon's depiction of a church community transformed by making Christ their Example for religious practice; and both Twain and Sheldon adopted Christian Liberalism handed down from New School seminaries in the Northeast, but set their stories on the outskirts of American society, providing commentary from the literal and figurative margins. Similarly, Harper's and Griggs's novels can be read as a late century call-and-response, as Harper insists that her fellow black Americans identify with Christ the Nazarene and embrace his sufferings through their own denial of self, and then Griggs underscores this ideal of Christian self-sacrifice by illustrating the dangers of racial separation and militancy.

To fully comprehend these writers, it is important to acquaint oneself with the theology of Christian Liberalism, which had a multitude of iterations and filtered into Unitarian, Congregational, Baptist, Presbyterian, Methodist, and African Methodist Episcopal church practice by transforming individual thinkers who looked to embody its ideals. At its heart, Gary Dorrien writes that, "Liberal theology is a tradition that derives from the late-eighteenth- and early-nineteenth-century Protestant attempt to reconceptualize the meaning of traditional 
Christian teaching in the light of modern knowledge and modern ethical values." ${ }^{\prime 15}$ Often this meant rejecting Calvinist doctrines and embracing a broad definition of freewill, and embracing "modern" values meant adopting principles of higher criticism regarding the study of scripture and led believers to train their gaze on the humanity of Christ Incarnate. Further, Christian Liberalism was explicitly "reformist in spirit and substance," and "fundamentally it is the idea of a genuine Christianity not based on external authority." ${ }^{\prime 16}$ For this reason Unitarian minister and Father of Christian Liberalism Horace Bushnell encouraged congregants to go beyond the walls of church and into the community — to "take a large and vital interest in our fellow man." ${ }^{\text {In }}$ In regard to the specifics of church doctrine and individual religious practice, Dorrien states that this liberal theological approach is open to "the verdicts of modern intellectual inquiry" (especially those in the natural and social sciences), it is committed to "the authority of individual reason and experience," it focuses on the "moral concepts of atonement," and most importantly it seeks to "make Christianity credible and socially relevant to modern people." ${ }^{18}$ So while the movement privileged the subjectivity of religious experience-expressed in the varied and sometimes conflicting theology of individual fictional texts, writers who ascribed to Christian Liberalism insisted on an Incarnational, modern, transformative, and transitional faith. Second, because Twain, Sheldon, Harper, and Griggs translate Christian Liberalism into an accessible even prescriptive gospel of reform, their works are reflective of a cadre of other writers in the late nineteenth century, who focused on reorienting American society by placing Christ at the center of social reform—novelists like Lew Wallace, Albion Tourgee, Elizabeth

15 Gary Dorrien, The Making of American Liberal Theology: Imagining Progressive Religion, 1805-1900. Louisville: Westminster John Knox Press, 2001. xxiii. 16 Ibid.

17 Ibid, 264, 53. Bushnell writes, "Now you hold your church by the tenure of a robber's castle... within which you may gather the spoil; whereas, it should rather be a city without walls, whither all may come at pleasure" (264). 18 Ibid. 
Stuart Phelps, W.D. Howells, Edward Eggleston, George Hepworth, E.P. Roe, Edward Everett Hale, Washington Gladden, Henry Ward Beecher, and Harriet Beecher Stowe (later works). Once again, these novelists are often neglected by literary scholars as their writing resists simple categorization and instead is best characterized as Christian Liberalist fiction. Together these writers remind us of the immense power of liberal Protestantism in the late nineteenth century, reflect the era's theological focus on Jesus as social reform Example, and they reiterate the limits of conventional literary periodization. In short these writers illustrate the "faulty... enduring legacy of [the] literary historical narrative" which argues that religious novels declined after the Civil War, making way for "the ascent of realism and naturalism.",19

Third, just as denominational affiliations shaded the individual theologies of Twain, Sheldon, Harper, and Griggs, their geographic location, too, charts the movement of liberal Christianity throughout the American landscape. This challenges the prevailing assumption that Christian Liberalism was concentrated in New England or that social reformers focused their efforts solely on urban spaces. In contrast, Twain is the rough-and-tumble Midwestern writer who spent his most productive and contented years amid noted Christian liberals; Sheldon, by contrast, is the frontier minister who sought to bridge persistent racial divisions in Kansas churches and schools with an Andover-bred theology; Harper was born as a free AfricanAmerican woman in the Mid-Atlantic who participated in A.M.E. reform activities but maintained regular church attendance in a majority-white Unitarian congregation; and Griggs began and ended his career in Texas, but spent his most active, prolific years in racially-divided Virginia and Tennessee, rising among Baptist leadership and working with white and black Baptist organizations. Together these writers and their reformist activities reanimate and relocate

19 Stokes, 168. 
a narrative of America's past that has, for too long, has remained staid.

Fourth and finally, each writer hailed a Christological theology that would shape American Protestantism for many decades to come. To the writers in this study, Jesus was the ultimate reformer, and if America had a way to heal its racial divide, they believed, it was through Jesus's practical message of compassion, sacrifice, and justice. For Twain, the sometimes-skeptic, Jesus was the Sacred Personage whose teachings exposed the "sham" of the American Church - an institution that sanctioned racial divisions, enslavement, and violence against the very individuals Christ instructed his followers to protect. And Jesus could right the course of American Christianity, too, Twain believed, but doing so required a radical return to his costly gospel. Sheldon's teachings celebrated selfless discipleship as the only true way to follow Christ's practical gospel and, to communicate his exhortations, Sheldon refashioned the popular genre of sermon story to reflect Jesus's own parables - an expression of the possibilities of liberal theology. For her part, Harper wrote explicitly to a readership of black believers, aligning the suffering of African Americans with Christ's suffering and proclaiming the future rise of the "black Nazareth." Then, at the turn of the century, Griggs depicted the quagmire of race reform and insisted that self-sacrifice was the only right response to Christ's atonement, even in an era with horrifying violence and bitter division inside and outside the church.

Historically, then, Twain, Sheldon, Harper and Griggs stood at a unique, fraught moment in American history, hoping to salvage the country’s Protestant past, transform individuals, and raise up despondent communities. In the end, these writers were humans who grew tired, who felt daunted by the challenge ahead of them, who experienced hardship, and whose views on racial reform changed as the years past, just as their personal experiences altered their views on God. And yet, as one century ended and another dawned, there was a moment — a sliver of a few 
decades - where their voices harmonized, where they mused on the unique possibilities of Christ's gospel for the racial divisions of their age, where they composed literary "sermons" on practical Christianity and distributed theses stories to a wide "congregation" of readers. The stories they created were compelling and brave narratives, then and now. Most significantly these tales require us to delve beneath the placid surface and wade into the swift, dangerous currents of America's racial and theological past; but, as Frances Harper remarked while risking personal safety to tour the South during Reconstruction: "It is not worth while to show any signs of fear." 20

In Chapter 1, I argue that Mark Twain's Adventures of Huckleberry Finn should be read as a survey of the theological crisis occasioned by the Civil War and an instructional homiletic narrative that testifies to a dramatic shift in postwar Protestant theology. In the 1880s as Twain drafted Huckleberry Finn, he was surrounded by elite Hartford ministers who were also the leading voices in Christian Liberalism, such as Horace Bushnell. By charting Twain's iconic novel alongside this liberal theology—most specifically Bushnell's teachings on the moral influence theory of atonement-we can better understand Huck's positioning between genuine, selfless Christianity (a human enactment of the atoning sacrifice of Christ) and the apostasy of the American church. Here Twain steps into the role of minister to the masses, a role he relished, and both reveals the extent to which progressive theology influenced fiction writers of the era and illustrates the ways in which literature could challenge mainstream, apolitical Protestantism through the discursive practice of storytelling.

For Chapter 2, I examine best-selling novelist Charles Sheldon who famously crafted

20 Harper qtd. in Boyd, 123. Melba Joyce Boyd, Discarded Legacy: Politics and Poetics in the Life of Frances E.W. Harper, 1825-1911. Detroit: Wayne State University, 1994. 
sermon stories that did not merely point heavenward but attended to the needs of Christ's earthly kingdom by urging believers to ask, "What would Jesus do?" and follow in Christ's steps of service and sacrifice. I trace his endorsement of discipleship to his lesser-known novella, The Redemption of Freetown, and, in doing so, recast Sheldon as a part of the larger institutional church movement led by African-American church reformers and later expanded into the Social Gospel movement of the twentieth century. To examine the catalyst for Sheldon's progressive views on race and social reform, I draw connections to his theological training at the liberal Andover Theological Seminary and discuss the ways in which Sheldon was a complex religious thinker whose understanding of the gospel was not simplistic, as scholars often argue, but merely advocated simple, radical fidelity to Christ.

Chapter 3 turns to Frances Harper as a prolific and revolutionary voice on race reform who experienced, first-hand, the ways in which the late century's preoccupation with whiteness created false division and who used her novel Iola Leroy, or, Shadows Uplifted to display the elevating potential of black believers aligning themselves with Christ's sufferings. Harper boldly questions the codification of race in the nineteenth century and then subverts her society's preoccupation with blood identity to reclaim the marked, non-white body as a site of power. While scholars have discussed her connection with A.M.E. churches and publishing houses, I argue that Harper's liberal theology is a product of her connection to Unitarian teachings about Christ as the ultimate example of suffering. Harper characterizes individual black believers as "living epistles" and refers to the black Christian community as the "black Nazareth"-important rhetorical moves that prefigure black liberation theology and elevates the position of African Americans in a racially stratified society.

Finally, Chapter 4 explores the slippery and routinely misunderstood nature of Sutton 
Griggs's reform efforts and argues that his novel Imperium in Imperio provides a scaffold for activism predicated on the doctrine of the "suffering Savior" and an absolute undying loyalty to the "black race" through individual self-denial. I explore the ways in which Griggs's Baptist upbringing and lifelong commitment to the denomination exposed him to ecumenical racial divisions but also illustrated the need for reform efforts to be interracial and dynamic. Griggs's novel and later non-fiction writings give us access to a forgotten stratum of American literary history that challenges our concept of race reform and provides a more flexible, less binaristic account of the era. Ultimately Griggs wanted to expose the horrors of American racial policies in a way that would spur other black Americans to action, even while cautioning them of what happens when a quest for justice turns into a pursuit for unchecked vengeance. And his constant rallying cry was for black citizens to "rally around the page" and exploit the possibilities of literature for their own elevation.

Taken together, these writers remind us of the ways in which sacred and secular were intertwined, inseparable in the late decades of the nineteenth century, and their voices form a chorus that, in the words of Langston Hughes, are "bitter with the past and sweet with the dream," falling "without a sound... yet heard everywhere." We must listen still. 


\title{
Chapter 1: \\ The Gospel of Mark: Twain on Race, Liberal Theology, and the Homiletic Story
}

\author{
"Hath any one in our day, as in St. Paul's, a psalm, a doctrine, \\ a tongue, a revelation, an interpretation - forthwith he wraps it up \\ in a serial story, and presents it to the public. ... We have Romanism \\ and Protestantism, High Church and Low Church and no Church, \\ contending with each other in serial stories, where each side \\ converts the other, according to the faith of the narrator." \\ --Harriet Beecher Stowe (1871) 22
}

In the spring of 1876 , Dwight L. Moody led a series of widely-publicized revivals in New York's Hippodrome, each day attracting tens of thousands of new converts, faithful Christians, and curious citizens alike. As he had done many times before, Moody explicitly called for a return to the "old Gospel, the old story," and reminded his congregation that he had "not come with any new Gospel” but to proclaim liberty through God alone, who “'hath chosen the weak things of the world to confound the wise."'23 Moody, himself, hoped to confound the wise of his day with his charismatic sermons, providing spiritual exhortation through carefully-crafted stories and homespun tales. Indeed, one of Moody's signature anecdotes on God's liberty — a parable he recounted many times that spring_illuminates a prevailing debate among American Christians in the post-Civil War era. In "Forty Miles to Liberty," two young (white) men tease an "old sambo" by pointing out a road sign, which reads, "Forty miles to Liberty." They ask, "Why don't you go and get liberty, it's only forty miles away?” The former slave replies, “Ah, massa, it points down that road to Liberty, but it's all a sham; but if it pointed up there it would point to Christ, and it would be true."24

22 Harriet Beecher Stowe, My Wife and I. 1871. New York: Riverside, 1967. xi.

23 Dwight L. Moody, Glad Tidings: Comprising Sermons and Prayer-Meeting Talks Delivered at the N.Y. Hippodrome. New York: E.B. Treat, 1876. 11.

24 Dwight L. Moody qtd. in Edward J. Blum, Reforging the White Republic: Race, Religion, and American Nationalism, 1865-1898. Baton Rouge: Louisiana State UP, 2005. 136. Moody reportedly told this sermon anecdote many times during his revival meetings, and so another variation of the tale (with minor alterations in wording) appears in Glad Tidings, 279. 
On the surface, Moody's parable asserts that true liberty can only come from Christ's redemption; but on a deeper level, the racially fraught anecdote dissuades Christians from taking up social causes, especially racial equality. For this endorsement of apolitical Christian orthopraxy, Moody could easily find an audience. In the 1870s, Moody himself had faced pressure from southern whites to segregate his revival meetings, which he did, signaling that the cause of earthly liberty was a "sham," and that religious concerns must take precedent. ${ }^{25}$ The feeling was a popular one in American Christendom, where white Protestants had become fractured in the post-Civil War decades; in the North, churches vehemently debated the fate of the South and whether it should be punished or forgiven for its racist sins, and in the South, congregations splintered along the color line and racial policies were made and re-made.

Hanging in the balance was justice for the millions of blacks who had only recently secured a tenuous freedom. As historian Edward J. Blum notes, the period between 1865 to 1875 became a religious, social, and political battleground for northerners "as advocates of sectional punishment and racial justice squared off against proponents of sectional harmony and racial oppression." ${ }^{, 26}$ To do their part, Moody and other "apostles of reunion" used sermons to endorse forgiveness, encourage unity, and point toward soul-saving heavenly work. ${ }^{27}$ Moody explicitly employed the pulpit to whitewash Christianity of social activism, arguing, "A heart that is right with God and man seldom constitutes a social problem, and by seeking first the kingdom of God and His righteousness, nine-tenths of social betterment is effected by the convert himself and the other

25 For more on Moody's choice of popularity over racial integration, see Edward J. Blum, "'O God of a Godless Land': Northern African American Challenges to White Christian Nationhood, 1865-1906. Vale of Tears: New Essays on Religion and Reconstruction. Ed. Edward J. Blum and W. Scott Poole. Macon, GA: Mercer University, 2005. 99-101.

26 Blum, Reforging, 88.

27 Ibid. 
tenth by Christian sympathy."28

Even as the South erupted in race riots, Jim Crow laws invalidated the Reconstruction Amendments, mob violence sparked lynchings, and white supremacist groups like the Ku Klux Klan and White League held the South hostage to their ideologies, Moody and his contemporaries Henry Ward Beecher, Harriet Beecher Stowe, and others, silenced their earlier calls for racial equality. Instead, they hailed the Christian's duty toward "sectional and ecclesiastical reunion"-reunion at all costs. ${ }^{29}$ Previously Protestants had led the campaign to "advance a racially egalitarian ideology that viewed former slaves as full citizens" and had "called for a universal brotherhood to transcend racial parochialism." ${ }^{30}$ But after the war, a "growing number of Protestants abandoned their commitments to civic nationalism... and came to authorize, rationalize, and at times lead the process of racial and national formation that left people of color disenfranchised, segregated, and without legal protection." ${ }^{31}$ Reconciliation between the North and South trumped racial reform efforts, even for northern evangelicals who had advocated for their "brothers" and "sisters" in chains. Now the focus was on "personal piety" with a subsequent "decrease of interest in social conditions." 32

But while Moody crafted his sermons for spiritual liberation, another prominent storyteller was targeting American Christendom for the cause of social liberty, pioneering the use of homiletic storytelling for a much different end. Samuel Langhorn Clemens began his iconic

28 Qtd. in Bernard A. Weisberger, They Gathered at the River: The Story of the Great Revivalists and Their Impact Upon Religion in America. Chicago: Quadrangle, 1958. 224. Such statements were common at Moody's revivals, and the minister was well-know for his arguments against any involvement in "secular" concerns. Moody argued that deeds outside of the church's walls were also outside of the church's purview, and he stated that such activities could potentially degrade a believer's own spiritual condition: "I have noticed that when a Christian man goes into the world to get an influence over the world, he suffers more than the world does" (qtd. in Blum 128).

29 Ibid., 91.

30 Blum, Reforging, 6.

31 Ibid.

32 Mark A. Noll, God and Race in American Politics: A Short History. Princeton: Princeton UP, 2008. 80. 
novel, Adventures of Huckleberry Finn, the same year as Moody's New York revivals, and the work was a culmination of his "radical 'conversion' regarding relations with black Americans.",33 In his hometown of Hannibal, Missouri, slavery was commonplace; and yet, as Clemens witnessed the brutality of the institution and became closely acquainted with African Americans, he came to despise slavery and the racist ideology that supported it. ${ }^{34}$ In the early days of his literary career, Clemens - through his fictional voice as Mark Twain — used his pen to compose screeds on slavery and racist treatment, as well as to condemn otherwise moral, Christian Americans for their complacency on the issue. ${ }^{35}$ In 1874 Twain entered the national literary scene with an essay in The Atlantic Monthly, titled, "A True Story, Repeated Word-For-Word as I Heard It." ${ }^{36}$ The sympathetic essay is a powerful counterpoint to Moody's "Forty Miles to

33 Ibid., 152.

34 For a detailed examination of slavery in Twain's hometown of Hannibal, as well as the ways in which Twain's views on slavery progressed throughout his life, see Terrell Dempsey's Searching for Jim: Slavery in Sam Clemens's World. Columbia, MO: University of Missouri, 2003. See especially "Chapter 10: The Face of Domestic Slavery in Hannibal" and "Chapter 20: The Great Change." Dempsey's careful study explains the historical context of Twain's upbringing, regarding the social, economic, cultural, and religious justifications for and implications of slavery in the Missouri territory; and Dempsey ends the book's "Postscript" with a poetic and important reflection on Twain's own "great change" in how he regarded slavery. Dempsey writes: "I began looking for Jim by reading Adventures of Huckleberry Finn. In the end, that is where I find him, fully fitted with heart and soul. It is a wonder to me that Clemens was able to breathe life into him. If I have accomplished anything, it has been to show that Hannibal was never the white town drowsing in the sun of Clemens's childhood idyl, but instead a place of turmoil, which increased as the nation slid into civil war. Clemens was subjected to the same ideology of oppression that kept Jim a slave. Samuel Clemens was able to overcome his upbringing and realize the full humanity of Jim. With his genius and empathy, Clemens has done one thing no historian will ever be able to do - he has breathed life into a long-dead slave. Through the fictitious Jim, we can hear the real Jim speak. I know that Huckleberry Finn is flawed. It must be. Clemens was white. He never suffered as a slave. ... His gift is that he cared deeply and watched closely. ... At a time when most white people thought African Americans weren't quite as human as they, he knew better" (280-281).

35 As early as 1869 Twain composed a column for The Buffalo Express, titled "Only a Nigger," which employed sardonic humor to dismiss the death of a black man in Memphis - a man who was denied his Constitutional liberty as a citizen and instead lynched by a mob of "high toned" southern gentlemen. The column was unsigned and created a great deal of discussion, something Twain prized.

36 "A True Story" purports to be the genuine life story of Mary Ann Cord, a black servant at Twain's boyhood home. In the retelling, Twain situates himself as the young, autobiographical narrator, who listens to and then relays Cord's story about her life — from being "bawn down mongst de slaves," to being beaten, seeing her family sold away, serving Union troops during the Civil War, and finally being reunited with her son Henry when he was a grown man. The story's refrain — of "no trouble, an' no joy!"—echoes a slave woman's denial of and desire for earthly liberty, and, as Jon Powell has demonstrated, Twain rhetorically connects Aunt Rachel to the biblical Rachel and to the character of Jim in Huck Finn, where Jim echoes Rachel's claim to "no trouble, an' no joy." This move reveals "Twain's respect for Jim in a context outside Huckleberry Finn, the context of interracial 
Liberty" anecdote, utilizing the same laissez-faire style, but by voicing the experiences of a slave woman, Twain's story has a decidedly political end. The account is told without interpretation, without Clemens or Twain needed to draw out a moral-of-the-story, and yet the publication was a turning point for Twain's career, as he publicly embraced racial equality and staked his claim as a chronicler of injustice. Ironically, Twain's gift for storytelling also exemplified Moody's sentiments when the preacher reflected, "Many a time I have found that when the sermon-and even the text—has been forgotten, some story has fastened itself in the hearer's mind, and has borne fruit. Anecdotes are like windows to let light in upon a subject. They have a useful ministry. ${ }^{\not 37}$ In other words, both rhetorical titans knew that a well-told story could motivate action in a way explication never could; but it was their dramatically different approaches to religion and religious practice that kept them at odds.

Just as theological changes led Moody to adopt storytelling in the pulpit, Twain pioneered a distinct brand of religious storytelling himself, employing the theology of Christian Liberalism to engender social change and advocate for racial justice in the United States. More broadly, Twain's writing demonstrates the reciprocal and sometimes contested relationship between preaching and storytelling that characterized the second half of the nineteenth century. Harriet Beecher Stowe, herself an example of how pre-Civil War concern for African American justice became subsumed by post-War gospel zeal, stated in 1871 that, "Hath any one in our day, as in St. Paul's, a psalm, a doctrine, a tongue, a revelation, an interpretation - forthwith he wraps it up in a serial story, and presents it to the public.... We have Romanism and Protestantism,

respect," which "forces a broader perspective on the novel," Powell argues. Such a connection also demonstrates Twain's "knowledge and use of the Bible at the time of his writing Adventures of Huckleberry Finn" (146). See Jon Powell, "Trouble and Joy from 'A True Story' to Adventures of Huckleberry Finn: Mark Twain and the Book of Jeremiah. Studies in American Fiction 20.2 (1992): 145-154. 146.

37 Moody qtd. in Kevin Belmonte, D.L. Moody. Nashville: Thomas Nelson, 2010. 131. I found very few works of scholarship that draw parallels between Twain and Moody, but Belmonte's biography of Moody does speak of the two as united in their love of anecdote and story. See particularly 128-131. 
High Church and Low Church and no Church, contending with each other in serial stories, where each side converts the other, according to the faith of the narrator." ${ }^{, 38}$ At first this comment may seem like an innocuous statement about the dynamic flow of religious ideas in the public sphere during Stowe's time. But closer examination reveals a typological link between sermonic storytelling in the nineteenth century and in "St. Paul's" day, when pubic arenas were alive with religious and secular debate. Further, Stowe underscores the method of storytelling which had become so popular: that of "serial stories" which poured forth from "High Church and Low Church and no Church" alike. Indeed, David S. Reynolds writes about this explosion of "pulpit storytelling" in the second half of the century, and argues "an increasing number of nineteenthcentury American preachers and homiletic theorists did combine their abandonment of strict Calvinist doctrine with an adoption of many of the same devices that were contributing to the popularity of religious fiction." ${ }^{39}$ In other words, a dramatic shift in theology —away from strict Calvinism—led preachers to shift away from mere doctrinal explication and to a more literary approach. Simultaneously, liberally minded fictional writers were also shifting their own approaches to social issues by incorporating homiletic realism into their writing. Or, as Reynolds states, "theological change and innovation in rhetorical theory... [also] helped engender religious fiction at the same time that they prompted narrative sermon form." ${ }^{40}$

In recent years, Twain scholarship has produced valuable and complex examinations into the author's belief and unbelief, with some writers noting the trajectory of Twain's faith and

38 Stowe, xi.

39 David S. Reynolds, "From Doctrine to Narrative: The Rise of Pulpit Storytelling in America." American Quarterly 32.5 (1980): 479-498. 480.

40 Ibid., 481. Unfortunately space does not allow me to provide an in-depth explanation of Reynolds's superb examination of ministerial style in the nineteenth century, but he does provide specific evidence of the theological changes and rhetorical approaches that sparked a movement toward storytelling in the pulpit. $\mathrm{He}$ names Moody among those who led the change, but also notes that Phillip Brooks and T. DeWitt Talmage also were leaders in pioneering the shift. 
others applying his theological leanings to various works, including Huckleberry Finn ${ }^{41}$. This chapter does not propose to displace those examinations, nor set forth just another narrow explication of Huckleberry Finn the text. Instead, I claim that Twain is representative of a late century faith crisis, rather than as an exceptional figure, and argue that, by "playing double" inside and outside the ecclesiastical sphere, he was able to use Adventures of Huckleberry Finn to represent the schism of American Christianity and advocate for a progressive theological shift. Without delving into specific Protestant doctrines, Twain nevertheless begins his novel with a divided look at Providence, charts the digression of American Christianity, and ends with a sharp implication of the church as theologically and practically beholden to "an unknown god."42 Twain emerges, then, as a striking antidote to the apolitical trajectory of some factions in American Protestantism, voiced by the likes of Moody, Beecher, and Stowe; and Twain's novel represents a stripe of liberal Christianity, just beginning to gain ground in the post-Civil War era, that would prefigure the Social Gospel movement of the twentieth century. Adventures of Huckleberry Finn, then, was Twain's sermon to the masses - an incarnation of what he would view as his highest calling and a kind of tableau vivant that depicted the American church's failure to enact its most basic principles. In this way, Twain represents a number of writersmany forgotten by history — who, on the margins of American Christianity, advocated for theological change in order to win social justice for African Americans and redeem Christianity from itself.

41 As I note later in the chapter, my investigation of Twain has benefited from the expert work of Twain scholars who have gone before me, most notably Harold K. Bush, who has conducted careful research into Twain's religious associations and church membership, his personal expressions of belief or unbelief, and his interactions with other religious schools of thought in his day. My work builds from my predecessors by looking closer at the theological doctrines of Christian Liberalism and the ways in which Twain interwove Adventures of Huckleberry Finn with these teachings of humanist Christianity for political and social ends.

42 This phrasing is taken from the Bible, in Acts, and its significance to the novel is explained in the last section of this chapter. 
More specifically, this chapter argues for Huckleberry Finn to be read as a survey of the "theological crisis" occasioned by the Civil War and an instructional homiletic narrative that testifies to a dramatic shift in postwar Protestant theology. As Huck travels down the river of his water-borne Odyssey, he progresses through multiple vignettes of American Christianity—a physical and spiritual journey that increasingly moves him to the margins of Christian and cultural practice and to a more liberal interpretation of truth and the social implications of belief. In this way, Huck and Twain himself, become representative of a larger dilemma in American society in the latter decades of the nineteenth century, when, as Mark Noll states, "old Christian doctrines such as 'reconciliation' and 'atonement' began to take on new meanings, involved much more with the divine development of the human spirit than with supernatural or juridical views of God's activity over humanity." ${ }^{, 43}$ As Twain's contemporary, Congregationalist pastor and proponent of "New Theology" Theodore Munger put it, these new interpretations of Christianity would "replace the excessive individuality of the old theology by a truer view of the solidarity of the race. ${ }^{44}$ Read alongside the texts of Christian Liberalism, Twain's Huckleberry Finn not only testifies to the progressive theological influences on one of America's most celebrated authors, but it also provides a foundation for sustained study into a crucial intersection in American literary and theological history: that moment in the latter decades of the nineteenth century when believers on the margins challenged mainstream, apolitical Christianity through literature and when progressive theology was remade through the discursive practice of storytelling.

\section{Questioning Christian Practice, or, Puncturing “a Great Many Shams”}

43 Mark A. Noll, A History of Christianity in the United States and Canada. Grand Rapids: William B. Eerdmans, 1992. 374.

44 Munger qtd. in Noll, Ibid., 374. 
For any critic attempting to categorize Mark Twain's religious life, the task is much like Huck's experience on the river, listening for Jim's call: "I went tearing after it, listening sharp to hear it again. The next time it come, I see I warn't heading for it but heading away... for I was flying around, this way and that and t'other, but it was going straight ahead all the time." ${ }^{, 45}$ It is precisely this elusiveness that makes Twain's spiritual life a rich example that "mirror[s] many of the major trends and developments in American religion. "46 Twain was at once fascinated by the possibilities and implications of creation and Darwin's theories of evolution; he could quote the Bible, chapter and verse, but also proclaimed, "no god and no religion can survive ridicule. No church, no nobility, no royalty or other fraud, can face ridicule in a fair field and live." ${ }^{, 7,48}$ For many decades, then, critics have focused on Mark Twain the Skeptic, scouring his journals, notebooks, and fiction, and portraying him as "an old despair- and grief-ridden white-haired man, shaking his fist at a silent God, snarling in rage at the weak-minded and hypocritical American church, and writing devastating critical assaults against the contents of Holy

45 Twain, Adventures of Huckleberry Finn, 100.

46 Harold K. Bush, Mark Twain and the Spiritual Crisis of His Age. Tuscaloosa: University of Alabama, 2007. 4.

47 See Mark Twain, Mark Twain's Notebooks and Journals, vol. 4. Ed. Frederick Anderson. Berkeley: University of California Press, 1979. 411. Twain's religious beliefs were anything but orthodox, but he did assert belief in an original Creator. In his biography of Twain, Albert Bigelow Paine discusses, at length, Twain's musings on the Creator God. Throughout his life, Twain endorsed the notion of God's transcendence but not necessarily his imminence. In other words, Twain saw God as the creator of the universe and everything in it, but did not believe that God was at all times present in the workings of that creation. As Bigelow recorded it, Twain said, "No one who thinks can imagine the universe made by chance. It is too nicely assembled and regulated. There is, of course, a great Master Mind, but it cares nothing for our happiness or unhappiness. [...] Two things are quite certain: one is that God, the limitless God, manufactured those things [aspects of creation], for no man could have done it....The other conclusion is that God has no special consideration for man's welfare or comfort" (1353, 1356). See Paine, Albert Bigelow. Mark Twain: A Biography, vol. 4. New York: Harper Bros., 1912.

48 While much is made, historically, about conflicts of faith and science in the nineteenth century, it's worth noting that many of the era's progressive religious thinkers saw no inherent conflict between evolution and Christianity. Among them, Henry Ward Beecher, Theodore Munger, Newman Smyth, and John Fiske all urged the church to embrace the opportunities that evolutionary theories provided for the church. For a fascinating study on the ministers' public discussions of Darwinian theory and the church, see Gary Dorrien's The Making of American Liberal Theology: Imagining Progressive Religion 1805-1900. Louisville: Westminster John Knox, 2001. See specially 293-304. 
Scripture. ${ }^{, 49}$ But such interpretations cast Twain as the exception-as the brash but comic deviant who sought to expel religion in favor of science and empiricism; such carelessness establishes anachronistic bifurcations between belief and doubt, sacred and secular, personal and social that, in the context of the nineteenth century, would have been unthinkable.

Rather, Twain's religious wanderings are strikingly representative of what many historians have called the post-Civil War "crisis of faith" and the refashioning of Protestantism that followed. In the last decades of "public Protestantism" $" 50$ in the United States, German higher criticism threatened biblical infallibility, Darwinian theories overturned literal interpretations of the Genesis story, the experience of the War led to sustained doubts about God's Providence, and each discovery of the microscope and telescope uncovered deep questions about divine design. But on a more personal level, Twain can also be located, geographically and intellectually, at the center of a burgeoning Christian Liberalism in New England, a movement led by the friends and neighbors who surrounded him for two decades as a member of the Nook Farm community, outside Hartford, Connecticut. There Twain kept close company with a rich array of America's preeminent religious leaders including fellow Congregationalists Horace Bushnell, Henry Ward Beecher, Thomas K. Beecher, Nathaniel Burton, and Edwin Pond Parker, as well as Catholic Father David Hawley, a noted Hartford social worker who ministered to "the forgotten of nineteenth-century urban America." ${ }^{\circ 1}$ Twain's dearest, lifelong friend was the Reverend Joseph Twichell, Bushnell's protegé, who pastored the Asylum Hill Congregational Church that Twain and his family attended from 1872 to $1889 .^{52}$

49 Bush, Mark Twain and the Spiritual Crisis of His Age, 5.

50 Noll, A History of Christianity, 287.

51 Bush, 127. For more on Twain's lifelong association with members of the clergy, see Bush, Mark Twain and the Spiritual Crisis of His Age, 52-53, 92, 127. In his early years in San Francisco, Twain kept company with Presbyterian minister Henry Scudder and Unitarian pastors Henry Bellows and Horatio Stebbins.

52 For discussions on Twain's close relationship with Twitchell, see Bush's excellent chapter titled, "Mark Twain's 
Indeed, the Hartford years were the most joyous of Twain's life, in large part because of his associations and the "community intimacy" they achieved. ${ }^{53}$ One of Twain's most meaningful experiences in Hartford came through his membership in the Monday Evening Club, which Bushnell founded to unite the threads of religious and academic discussion. Twain became a member of the club in 1871 and remained a member throughout his time in Hartford, with his name on the group's roll for the rest of his life. ${ }^{54}$ These regular discussions with Hartford's intelligensia became a touchstone for Twain's literary and spiritual development, and while he ultimately rejected traditional, orthodox Christianity, he was "not contemptuous of Christianity as a basis for an equitable society." ${ }^{, 55}$ Part of what Twain admired most about the group from the

Pastor," 83-125; for another comparison between Twitchell and the character of Uncle Silas, in Huckleberry Finn, which I later examine, see Kaine Ezell, "Uncle Silas in Huck Finn: 'A Mighty Nice Old Man." Mark Twain Annual (2011): 98-110.

53 Kenneth R. Andrews, Nook Farm: Mark Twain's Hartford Circle. Cambridge: Harvard University Press, 1950. 78.

54 The Monday Evening Club was a gathering of Hartford's intelligentsia. Bushnell founded the group, along with Calvin Stowe (husband of Harriet Beecher Stowe) and James Hammond Trumbell (who later worked with Twain and Charles Dudley Warner, also a member of the group, when they wrote The Gilded Age). The Monday Evening Club gathered in a member's home every two weeks, October to May, and one of the men would deliver a short essay, followed by discussion. The topics included a host of issues pertaining to religion, current events, politics, science, and literature, and the lists of these topics have survived in a detailed compilation by Howell Cheney. For his part, Twain used the group to try out ideas for his upcoming novels and short stories, and he interacted with the most influential individuals in American progressive religion: Bushnell, Twichell, Edward Parker, Nathaniel Burton. For a more extensive discussion of the Monday Evening Club and its topics, see Bush, Mark Twain and the Spiritual Crisis of His Age, 114-117; and see Andrews, Nook Farm: Mark Twain's Hartford Circle, 102-109. For the original chronicling of the group: Howell Cheney, The List of Members of the Monday Evening Club, Together with the Record of Papers Read at Their Meetings, 1869-1954. Hartford: privately printed, 1954. Mark Twain Papers. University of California, Berkeley.

55 Twain qtd. in Andrews, 70. As for Twain's views of Calvinism and more traditional Protestant theology, Berkove provides an in-depth discussion in his chapter "Twain's Countertheology," the finer points of which cannot be represented here, due to space. I disagree with some of his conclusions about Twain's theologyparticularly his belief that Twain ascribed to Calvinist predestination, since Twain seemed to critique such laissez-faire theology in exchange for a focus on free will and moral agency. The entire novel Adventures of Huckleberry Finn seems in opposition to the idea that human action (specifically, salvation from sin) is predestined. Second, Berkove believes Twain held a more conventional notion of sin than his writing would suggest, and Twain was particularly critical of the church definitions of sin-from drinking and smoking, which he believed should be permitted, to more serious issues as are addressed in Huckleberry Finn. However, Berkove's theological examination of Calvinism and Twain's gospel should be praised for refusing generalization and acknowledging the debates about free will and predestination that swirled around Twain. Ultimately Berkove correctly argues: "Although there is much overlap between Twain's creed and that of traditional Calvinism, the 'spin' that Twain puts on his gospel renders it daringly heretical from the perspective of Calvinism. ... This gospel drives his fiction and is a distinguishing feature of it" (14). 
Asylum Hill Church and the Monday Evening Club was their ability to entertain a wide variety of issues - many contentious and ideologically opposed to one another, from race relations to scientific theories. This "modeled a progressive form of intellectual pursuit from a Christian perspective," that allowed Twain to voice his belief that Christian society must not enslave human beings or human minds. ${ }^{56}$ Speaking as part of a lecture series Twichell organized at Asylum Hill Church, Twain read from his not-yet-published manuscript of Huckleberry Finn and was received by the congregation with "tumultuous applause. ${ }^{, 57}$ In other words, it was in the 1870s and 1880s that Twain's moral sensibilities, spiritual quest, and creative talent came together in a community of Christian liberalism. Twichell and others defended Twain's sense of religion ever after-from his beliefs in heaven and the afterlife to his deep reverence for Christ's teachings. Henry Van Dyke said of Twain: "His sense of humor made him keenly aware of [Christianity's] perversions and literal misinterpretations. ... of genuine, simple Christian faith I never heard him speak without loving reverence." 58

Just a few years before beginning Adventures of Huckleberry Finn, Twain acknowledged his longing to become a minister, and he explained to his brother Orion that, as ministers are called to preach the gospel, his calling was to literature- his way of preaching a social gospel to a broader American congregation. In the letter ${ }^{59}$ Twain wrote that he "never had but two powerful ambitions" in his life: "One was to be a pilot, \& the other a preacher of the gospel.,60

56 Andrews, 70.

57 Bush, 113-114.

58 Van Dyke qtd. in Bush 279.

59 Twain's letter has been called his "suicide letter," because it was penned near to the time when Twain said he "put the pistol to my head but wasn't man enough to pull the trigger." Twain recalled the event as an "experience of 1866," though it wasn't until 1909 that Twain remarked on the incident in a marginal note to his copy of the Letters of James Russell Lowell. In January of 1866 Twain boasted to his mother and sister about his newfound literary success, so the suicide event must have happened sometime between the late days of 1865 and middle of January 1866.

60 Samuel Langhorn Clemens to Orion and Mary E. (Mollie) Clemens, 19 and 20 Oct 1865, San Francisco, Calif. (UCCL 00092). 
As for his decision to choose the Mississippi over the ministry, Twain writes, "I accomplished the one \& failed in the other, because I could not supply myself with the necessary stock in trade-i.e. religion." ${ }^{61} \mathrm{He}$ felt his "calling" was "to literature of a low order-i.e. humorous," but even in this explanation he goes on to incorporate a religious text, echoing a biblical parable from Matthew 25: Twain states that he would "listen to that maxim of stern duty which says that to do right you must multiply the one or the two or the three talents which the Almighty entrusts to your keeping." ${ }^{, 2}$ To be faithful to this duty, Twain would turn his "attention to seriously scribbling to excite the laughter of God's creatures," which he did until his death in $1910 .{ }^{63}$ But while Twain separates his ambition to be a preacher of the gospel from his "calling" as a humorous writer, as his life continued, the lines between these two occupations blurred in unconventional ways. It is important to note, too, that Twain points to his lack of religion, not of spirituality or faith, both of which Twain explored in great depth in his many discussions with the Hartford Circle and throughout his prolific writing career. ${ }^{64}$ Through his fictional voice as Mark Twain, Samuel Clemens found a mainstream arena in which to challenge American Christianity on its own grounds - all in a way that held Americans to the intellectual standard of morality expressed in the Hartford Circle and that distinguished between what his friend and contemporary Frederick Douglass deemed "the Christianity of this land and the Christianity of

61 Ibid.

62 Ibid.

63 Ibid.

64 In his carefully worded chapter on "Mark Twain's Roots," Bush urges caution for scholars who interchangeably use terms like "religion," "spirituality," "belief," "God," and the "gospel," stating that "To get serious about historical religion, one must begin by questioning and complicating what basic terms like these actually mean (36). Bush goes on to provide examples from Twain's own life and works that complicate nineteenth century Protestant belief which, historically, is often considered in monolithic terms: "An important clue to a reliance on limiting preconceptions is to be found in the tendency, for example, to generalize about the Calvinism of the early republic. In particular, the years of Sam Clemens's youth were marked by large controversies within the Calvinist Protestant churches of America, several of which were so crucial that they would literally end with schismatic separations. Furthermore, these issues were ultimately reflected in the major themes of Twain's writing career. Understanding the nature of humanity, and the opposition of free will versus determinism, for example, is arguably the primary burden of Mark Twain's writing as a whole" (36-37). 
Christ." 65

In the past decade a cadre of scholars has investigated the ebb and flow of Twain's spirituality, but none closely explicate the theology of Christian Liberalism to demonstrate how this shift in sacred perspectives initiated a broader, influential movement in American literary history. ${ }^{66}$ To understand the extent to which evolving theologies displaced long-standing Calvinist models after the Civil War, one must begin with Twain's friend and neighbor Horace Bushnell, the leading figure of Christian Liberalism in America. The two exchanged letters, discussed ideas during the Monday Evening Club sessions, and, while not close, Twain often remarked on his deep respect for Bushnell and his theology, calling him "that greatest clergyman that the last century produced."67 Twain's closest confidante, Joe Twichell, was trained and mentored by Bushnell, and while Twain maintained separate ideas about faith and theology, core teachings of Christian Liberalism certainly permeated his concept of religion and its practice. He embraced its focus on socially minded activism, especially in regard to slavery and racial discrimination, and he was intrigued by the ways in which liberal theology melded biblical

65 See Frederick Douglass, Narrative of the Life of Frederick Douglass, an American Slave. 1845. New York: Penguin, 1982, 152. While there appears to be no correspondence between Twain and Douglass, Twain was an admirer of Douglass and spoke favorably of him. In January of 1881, Twain wrote to then president-elect James Garfield, advocating that the retain Frederick Douglass in his present position of marshal of the District of Columbia. Twain wrote: "I offer this petition with peculiar pleasure and strong desire, because I so honor this man's high and blemishless character and so admire his brave, long crusade for the liberties and elevation of his race. He is a personal friend of mine, but that is nothing to the point - his history would move me to say these things without that. And to feel them, too" (Twain qtd. in "Was Mark Twain a Racist?" University of Virginia, last modified April 4, 1997, http://www.virginia.edu).

66 Such critics include Dwight Eutsey, Stanley Brodwin, Lawrence Berkove, Peter Messent, and Joe B. Fulton. Harold Bush, from whom I draw inspiration, does, in fact, claim Twain as historically representative, and argues that more work needs to be done to place Twain at the center of a movement in literature and theology. For this reason, I would argue that Bush's work is incredibly important for future scholars who wish to situate Twain within his spiritual and literary context, in order to address specific works in Twain's canon. It is also important to note that the 1960s and 1970s saw a rise of inquiries into Twain's belief and his representations of religion, illustrating that times of societal realignment often result in historical reflection. Many of these Twain scholars laid a foundation for future examinations of his spirituality, such as Louis Budd's Mark Twain: Social Philosopher, Allison Ensor's Mark Twain and the Bible, Maxwell Geismar's Mark Twain: An American Prophet, Caroline Harnsberger's Mark Twain's Views of Religion, Charles Neider's "Mark Twain: Reflections on Religion," and Hamlin Hill's Mark Twain: God's Fool.

67 Twain qtd. in Bush, 94. The quote is from 1902. 
scholarship with emerging theories of higher criticism and a Unitarian emphasis on the teachings of Christ (not his divinity).

As early as the 1840s Bushnell laid a theological foundation that supported Christian Liberalism for nearly a century. His systematic approach sought to transcend the deepening divide between Old School and New School Congregationalists in New England by offering a theological blueprint that would, in his words, "comprehend, if possible, the truth for both." Bushnell published his landmark Christian Nurture in 1847, added to his new theology with God in Christ in 1849 (a series of addresses given at Harvard, Yale and Andover), and challenged traditional views on the atonement in The Vicarious Sacrifice, published in 1866. Together, the works developed themes that came to dominate modernist religious thought in the latter half of the century: the immanence of God, the importance of Christian experience, the moral influence theory of atonement, and a poetic (rather than literal) nature of religious language.

Bushnell's theology was a dramatic departure from the prevailing Protestant teachings that blanketed the nation prior to the Civil War. In his slim but thorough study The Civil War as Theological Crisis, Mark A. Noll details the extent to which certain evangelical Protestant doctrines dominated the religious landscape prior to the War. He writes that fidelity to the Scripture, Enlightenment principles, teachings about Providence, Republican ideals, and America's "covenantal relationship with God" all "structured the national crisis, as well as the

68 The debates between Old and New School Congregationalists and Presbyterians are complex and span several decades from the evangelical revivals of the Second Great Awakening, through the Civil War, and into the early twentieth century. For a detailed examination of each denomination's doctrinal differences, see The Dictionary of Christianity in America. Ed. Daniel G. Reid. Also see Roger Finke's and Rodney Stark's The Churching of America, 1776-1999: Winners and Losers in Our Religious Economy. New Brunswick, NJ: Rutgers UP, 1992. 54-108. For a close examination of the Second and Third Great Awakenings, see William G. McLoughlin's Revivals, Awakenings, and Reform: An Essay on Religion and Social Change in America, 1607-1977. Chicago: University of Chicago, 1978. 98-178. 
theological crisis" of the era. ${ }^{69}$ Both Northerners and Southerners believed that they could read and interpret the Bible plainly and that God's will could be divined by anyone who faithfully examined the Scriptures as the Creator's inerrant communication with his creation. As for the nation's destiny, Protestants held to the teachings of God's Providential care for his chosen people, arguing — often from a typological belief — that America had been divinely established according to God's will and that He would guide the nation to success and prosperity. Viewing God's relationship to America as covenantal in origin, both North and South held to the Bible's promise of deliverance, as outlined in the Old Testament. Noll writes that Protestants throughout the nation understood themselves as part of a "time-honored pattern of covenant, as taken over from a reading of the Old Testament: repent and God may reverse evil days; give thanks and He may allow the propitious times to come." ${ }^{, 70}$ Surely, Americans believed, God would deliver those who upheld a righteous cause and thereby shield the nation from war, for its future purpose.

But wading through the troubled waters of slavery made murky God's Providential plan. Indeed, both Confederate and Yankee Protestants believed their cause to be divinely sanctioned, each touting theological justifications for or against slavery. At its heart the War was, itself, a religious endeavor, best characterized by the editor of the Army and Navy Messenger who, in an 1865 editorial, collapsed sacred and secular by reminding troops: "The character of the war is, with us, essentially and necessarily religion. ... In its simplest form, the war with us [is] for freedom of conscience-freedom to interpret the Bible and worship God according to the dictates of our own consciences." ${ }^{, 71}$ For many Americans, then, the Civil War functioned as a

69 Mark A. Noll, The Civil War as Theological Crisis. Chapel Hill: University of North Carolina, 2006. 1-29, 18, 28.

70 Ibid., 18.

71 “The Rev. C. C. Gillespie at Camp Chase," Army and Navy Messenger for the Trans-Mississippi Department, 2 March 1865, 1. Qtd in Kurt Berends, "'Thus Saith the Lord': The Use of the Bible by Southern Evangelicals in the Era of the American Civil War.” Dissertation. Oxford: Oxford UP, 1997. 236. 
theological reckoning after which few denominations, church congregations, or individual believers remained unaltered. Theologians and ministers across the nation sought to make sense of the War's outcome and what it meant for the United States and American Christianity itself. Charles Hodge of Princeton Theological Seminary argued that the end of slavery—a "system so fraught with evil" - was the "design of God," and he exhorted Christians to accept "the inevitable difficulties and sufferings consequent on such an abrupt change., ${ }^{, 72}$ But on the whole, American thinkers after the War were increasingly divided between those who continued to interpret Providential actions of God and those who grew weary of such interpretations. For most Christians the dilemma was "not trust in Providence as such but trust in Providence so narrowly defined by the republican, covenantal, commonsensical, Enlightenment, and — above all— nationalistic categories that Protestant evangelicals had so boldly appropriated with such galvanizing effects" earlier in the century. ${ }^{73}$

Into this contested social and theological space, where the dominant racialized order in American society and the dominant teachings of American Protestantism had withered, grew Christian Liberalism, sowed by Bushnell and his contemporaries and cultivated, in some form, by Twain and other storytellers in the twilight of the nineteenth century. For his part, Bushnell had grown frustrated with strict, Puritanical interpretations of theology and Calvinist doctrines, arguing in 1866 that, "through abstractive theology we are taken away from men, and become practically unsphered, or disabled." ${ }^{74}$ Pulled away from social and political causes at midcentury, Protestant theologians were "looked upon rather as abstract men than as men alivetheologic lay figures, sombre, introverted, dreary-looking faces, beholding always, sticking for

72 Hodge, qtd. in Noll, The Civil War as Theological Crisis, 83.

73 Ibid., 94.

74 Horace Bushnell, Pulpit Talent, Training for the Pulpit Manward, Building Eras in Religion, and Literary Varieties. London: Folkard \& Sons, 1882. 45. 
and as it were becoming the inevitable propositions." ${ }^{75}$ In other words, Bushnell believed theology and church practice had focused its attention too much on the heavens - on looking upward at God, rather than outward at creation — and in this way had failed to move beyond the church's "walls," into the needs of humanity itself. Religious leaders in America prized intellectual knowledge of Scripture, doctrine, and church history, Bushnell said, but they neglected to "take a large and vital interest in our fellow man."76

Bushnell's theology was modern, incarnational, and transformative-a fitting corollary to Twain's portrayal of "orthodoxy" and "apostasy" in Adventures of Huckleberry Finn. ${ }^{77}$

Bushnell's modernity belied American Protestantism's resistance to higher criticism, and his focus on Christ as incarnate God came from a personal experience of divine revelation. Bushnell emerged with a "new sense of the glory of Christ" and the transforming power He gave to believers. ${ }^{78}$ In particular Bushnell's discussion of the moral influence theory of Jesus's atonement would eventually inspire liberal Christianity to social action and encouraged parishioners, once again, to consider their "fellow man." According to the moral influence theory, the purpose of Christ's death was to inspire humankind to moral improvement, a belief that stands in contrast to more traditional views of Christ's death as satisfaction of divine justice. In other words, the atonement was not directed toward God but toward humanity. Bushnell, and others after him,

75 Ibid., 45.

76 Ibid, 264, 53. Bushnell writes, "Now you hold your church by the tenure of a robber's castle... within which you may gather the spoil; whereas, it should rather be a city without walls, whither all may come at pleasure" (264).

77 As will be discussed in the next section, Twain inverts traditional definitions of orthodoxy and apostasy in the character of Huck, and alludes to these inverted definitions with the character of Uncle Silas; in other words, Huck's actions depict apostasy (not turning Jim in, but setting him free) to be true Christianity (aligned with New Testament teachings of a common humanity), while orthodoxy (preserving slavery and racism to abide by earthly law) is revealed to be a sham.

78 Bushnell qtd. in Dorien, 141. Dorien also devotes space to describing Bushnell's "experience of revelation" in February of 1848, stating it was a "convicting mystical experience of Christ as a living, personal power" that "enabled him to link his themes of nurture and divine indwelling to a more explicitly supernaturalist Christianity" (141). For more discussion on how Bushnell's theology influenced the next generation of religious thinkers, see Noll's A History of Christianity in the United States and Canada, Chapter 6. 
would harness this theological approach to encourage social action, by emulating Christ's concern for "the least of these" and fighting against a host of social injustices from poverty to alcoholism, and from racism to xenophobia. ${ }^{79}$

Just as Twain's first national publication of "A True Story" exposed slavery as inhumane, Bushnell's first published sermon attacked Protestant political support of the same "peculiar" institution. Writing to condemn a mob attack against abolitionist leader William Lloyd Garrison in Boston, he devoted the 1835 sermon, "The Crisis of the Church," to identifying "principal dangers" to the nation—namely "slavery, infidelity, Romanism, and the current of our political tendencies. ${ }^{\prime 80}$ Bushnell's contemporary, Reverend Theodore Munger, summarized the sermon's "chief thought" as: "Protestantism in religion produces republicanism in government. ${ }^{81}$ In short, for Bushnell, the transformative, even mystical, power of Christ's spirit could and should influence believers to eradicate injustice throughout society — an aspect of lived theology he expounded from the early decades of the 1800 s until his death. Twain, too, "hated social injustice with the ardor of crusaders," though neither he nor Bushnell should be viewed anachronistically as "staunch advocates of equality and civil rights" on all fronts. ${ }^{8283}$ Rather, Bushnell and Twain

79 The phrase "the least of these" comes from Matthew 25, in which Christ teaches about the Last Judgement. In this telling, Christ as King of Creation and final Judge says to believers: "Come, ye blessed of my Father, inherit the kingdom prepared for you from the foundation of the world: For I was an hungered, and ye gave me meat: I was thirsty, and ye gave me drink: I was a stranger, and ye took me in: Naked, and ye clothed me: I was sick, and ye visited me: I was in prison, and ye came unto me. Then shall the righteous answer him, saying, Lord, when saw we thee an hungered, and fed thee? or thirsty, and gave thee drink? When saw we thee a stranger, and took thee in? or naked, and clothed thee? Or when saw we thee sick, or in prison, and came unto thee? And the King shall answer and say unto them, Verily I say unto you, Inasmuch as ye have done it unto one of the least of these my brethren, ye have done it unto me." (Matthew 25.35-40, KJV). I have chosen to quote from the King James Version of the Bible, when referencing specific biblical teachings and texts, as it was the most popular version of the late nineteenth century. The English Revised Version debuted in the U.S. in 1881, which would have come after Twain's main period of writing for Huckleberry Finn. For a brief and useful discussion of the so-called "New Bible" and how it impacted Twain's circle, see Bush, Mark Twain and the Spiritual Crisis of His Age, 120125.

80 Qtd in Theodore T. Munger, Horace Bushnell: Preacher and Theologian. Boston: Houghton, Mifflin \& Co., 1899. 52.

81 Ibid, 52.

82 Guy Cardwell, Twins of Genius. Michigan: Michigan State College Press, 1953. 67. 
used their respective "pulpits" specifically to advocate for the eradication of slavery and racial persecution, while underscoring the need to affirm a common humanity under God. Bushnell believed that the nation's wealth and moral prosperity depended on "the total value of the persons of the people [the Republic]," and that the transformational work of the Incarnate God was essential, not ancillary, to this improvement. ${ }^{84}$ Similarly, Twain ardently asserted that all people were created by one God and that a sense of one common humanity should prevail above all theological, national, political, and especially racial differences.

For Twain, then, this new stripe of liberal Christianity, while not entirely dedicated to racial justice, did restore a sense of the individual believer's duty to humanity, something he insisted many of his contemporaries, like Moody, had forgotten. In his view, this moral code came not from an incarnate God but the "Sacred Personage" of Jesus. In 1878, Twain wrote to his brother that "Neither [William Dean] Howells nor I believe in hell or the divinity of the Savior but no matter, the Savior is none the less a Sacred Personage, and a man should have no desire or disposition to refer to him lightly, profanely or otherwise than with the profoundest reverence." 85 This profound "reverence" for "the Savior" suffused Twain's convictions about responsibility to society's weakest, neediest members, and he would have agreed with Bushnell's

83 While space does not allow me to parse out the specifics of this statement, there are certainly ways in which Twain harbored what Bush calls "frontier racism" until the end of his life and Eric Lott has provided extensive (and at times misguided) analysis of Twain's fraught portrayals of race. But, from a historical perspective, it must be noted that Twain's enlightened views on race were strikingly liberal in his time. As for Bushnell, early in his ministry he argued against slavery, but did so with an assumption of Anglo-Saxon superiority. He claimed slavery brought down the entire race because blacks were an "uncultivated race" bound for logical extinction at some point in history. After the War, however, Bushnell's social views became more liberal, as he embraced more fully the teachings of the incarnational Christ and the transformative power of a theology bent toward social betterment. For more on Bushnell's racial views, see Dorien, Chapter 3; see also David Torbett, "Horace Bushnell and 'Distinctions of Color': Interpreting an Ambivalent Essay on Race." Prism 14.2 (1999): 3-24.

84 Qtd. in Howard A. Barnes, Horace Bushnell and the Virtuous Republic. Metuchen, N.J.: Scarecrow, 1991. 19.

85 Earlier in his writing career, Twain had confessed to his lack of religion-specifically his inability to find "that inner sense which tells me that what I do I am doing for love of the Savior"; later in life, he continued to search for what he called "the divine spark" that "confers upon us kinship with God." (Mark Twain Archives. Letter. 27 Dec.1868; qtd also in Bush, Mark Twain and the Spiritual Crisis of His Age, 269.) 
assertion of the same in an 1882 sermon: "[We] must go into by-places and dark neighborhoods, seeking out Christ's poor and sick, drawing others out of the wrecks of fortune and the more appalling wrecks of vice... teaching the ignorant, and especially bending [ourselves] upon the neglected little ones of the street. ... Mercies are greater things than notions, and here is the place to learn the mercies. ${ }^{" 86}$ In Twain's view, too, American audiences were receptive to discussions of religious duty and justice, if couched in relatable, sometimes humorous stories. By crafting vignettes of American Christianity, Twain not only "plants the seed of religious skepticism," but also critiques religious practice the same way Bushnell exposed the church for its inability to translate their "notions" into "mercies." ${ }^{, 87}$ For both Hartford firebrands, moral action was at the center of any lived theology. Incarnationalism, with its focus on Christ's teachings, had the potential to return Christianity to the "Sacred Personage" and stamp out the version of Christianity that extolled the sham of slavery and racist practices.

Finally, Bushnell's modern theology included a poetic definition of preacher-scholar that questioned the stability of language and widened the scope of theological knowledge. In writings that prefigure twentieth-century debates about the referential nature of language and Derridean discussions of "transcendental signifieds," Bushnell insisted language was figurative, slippery, and unspecific. In his opening essay in God in Christ, Bushnell described language as "instruments of thought" that could be shaped and molded, but were not infallible when communicating theological truth. ${ }^{88}$ Only the Word as Divine Logos could be a pure representation of God's truth, Bushnell believed, and the physical and intellectual "departments" of language fail to consistently represent concepts like sin, heaven, or hell. Even scripture was an

86 Bushnell, Pulpit Talent, 54-55.

87 Lawrence I. Berkove and Joseph Csicsila, Heretical Fictions: Religion in the Literature of Mark Twain. Iowa City: University of Iowa, 2010. 56. 88 Bushnell, God in Christ, 13. 
imprecise representation, he said, which angered conservatives and liberals alike, but connected to the currents of higher criticism emanating from Europe. Language was a tool useful for communication, but it was subjective and unreliable and, thus, should be interrogated as any scientific discovery or intellectual theory. Although words, knowledge, and thoughts had been imparted by the Creator, but their meaning was subjective and shaped by individuals.

Decades after Bushnell published his theories, Twain himself argued for God as the "Originator of thoughts; thoughts suggested from within not from without. . . He made the materials of all things... by which only man may combine them into machines and other things which outside influence may suggest to him. ${ }^{, 89}$ For both Bushnell and Twain, language and knowledge, science and observation, experience and intuition, were all raw materials that could be transformed with a message. In this vein, Bushnell and Twain were most united in their intellectual endeavors, embracing the subjectivity of modernist belief in order to transform social practice. To this end, Bushnell's thoughts are most instructive, and reveal a characterization of "preacher" that extends to Twain himself:

[The preacher's duty] is to be universal; to be out in God's universe, that is, to see, and study, and know every thing, books and men and the whole work of God from the stars downward; to have a sharp observation of war and peace ... to have bored into society in all its grades and meanings, its manners, passions, prejudices, and times; so that, as the study goes on, the soul will be getting full of laws, images, analogies, and facts, and drawing out all the subtlest threads of import to be its interpreters when the preaching work requires. ... [Above all the sermon must be] a living observation of men and [the preacher] must see the men, the women, the children, the neighborhood, the nation, the

89 Qtd. in Geismar, "Mark Twain's God,” 154. 
times, dramatizing themselves in what is called society. ${ }^{90}$

If a preacher could harness a broader sense of higher design, based on lived experience and attuned to social needs, then the transformational work of Christ's sacrifice could begin. For Twain, this transformation had to start with the eradication of racial injustice, and the model for change was Christ's teachings, divinity or no.

Against this dynamic religious backdrop, Mark Twain penned Adventures of Huckleberry Finn - as the Civil War's end converged with new theories of language and theology, as he walked and talked with prominent theologians who sought to remake the American church, and as he questioned his own views on God and infused his social commentary with critiques of Christian practice. For all of these reasons, it is reductionist and anachronistic to say that Twain "ruled out all theology" or to consider Huckleberry Finn a "comic and emancipatory view of secularization. ${ }^{91}$ Rather, Twain's concepts of racial justice took shape because of the deep and sustained influence of Protestant doubt and Christian Liberalism in his everyday life. Despite his own belief or unbelief, he was convinced that, in a Christian nation, Christianity could operate as a powerful rhetorical tool for social change. In its historical context, then, Huckleberry Finn reflects the late-century chaos of faith and, as a reporter stated in 1885, it reveals Twain's own desire to "puncture a great many shams"- the most egregious being the hypocrisy of American Christianity. ${ }^{92}$ The Hartford intellectual knew the best way to convict a "Christian" audience was to create a "Christian" story_ one that painted a vivid picture of American society in slavery's aftermath, and one that brought current theological discussions to bear on the problem of racism. Twain lamented what he called "the lie of silent assertion," by which "whole races and peoples

90 Ibid., 6.

91 Andrews, 70; Tracy Fessenden, Culture and Redemption: Religion, The Secular, and American Literature. Princeton: Princeton UP, 2007. 139. Emphasis added.

92 San Francisco Evening Bulletin. 14 March 1885. University of Virginia. http://twain.lib.virginia.edu 
conspire to propagate gigantic mute lies in the interest of tyrannies and shams." In relation to slavery and racism in the U.S., he concluded: "The silent colossal National Lie that is the support and confederate of all the tyrannies and shams and inequalities and unfairness that afflict the peoples - that is the one to throw bricks and sermons at." ${ }^{93}$ His sermon was Huckleberry Finn.

\section{Homiletic Realism, Individual Action, and the Fight Against Racism}

In a well known essay by Flannery O'Connor, the twentieth-century fiction writer offered the following advice to novelists with "Christian concerns" who may encounter a "hostile audience": "Make your vision apparent by shock - to the hard of hearing you shout, and for the almost blind you draw large and startling figures."94 Such was Twain's approach in the pages of Huckleberry Finn, where years of simmering frustration with complacent Christianity and righteous outrage over the treatment of African Americans found irreverent expression. Twain knew his audience was deaf and blind to the ways in which "the text of slavery" still existed in 1885 , and they would have to be startled into admitting Christianity's complicity in the matter. ${ }^{95}$ But just as dramatic shifts in theology moved America's intellectual class in new directionsworking out their salvation through higher criticism and social involvement - so Twain's novel posited a modern theological challenge: was the "Christianity of this Land" at all related to the "Christianity of Christ"? ${ }^{96}$ And, by extension, was the American church a bastardized version of

93 Geismar, 212-213. From the essay "Lies and Civilization" published in 1900 in The Man That Corrupted Hadleyburg and Other Tales. New York: Harper and Bros., 1900.

94 Flannery O'Connor, The Correspondence of Flannery O'Connor and the Brainard Cheneys. Ed. C. Ralph Stephens. Jackson, MS, 1986. 192.

95 Twain qtd. in Geismar, 109. Twain originally penned the essay "Bible Teaching and Religious Practice" in 1890, and it was published posthumously by Albert Bigelow Paine in the collection Europe and Elsewhere (1923). The phrase "slavery text" certainly referred to the Bible, specifically, but in the essay Twain also attacks religious practice. He concludes the screed: "It does certainly seem to suggest that if man continues in the direction of enlightenment, his religious practice may, in the end, attain some semblance of human decency" (110).

96 Once again I am borrowing the phrasing from Douglass, 152. 
a "morality" that justified African American enslavement and held captive, rather than freed, the hearts and minds of believers? More specifically, while critics have hailed Huckleberry Finn's realism for over a century, it is more productive to view the novel as an example of "homiletic realism," which glanced backward at Calvinism's failings and forward to liberal Christianity's possibilities for racial justice. In this way, a broader understanding of nineteenth-century realism melds with the era's crisis of faith regarding the existence and representation of truth. Twain's approach to blending fiction with theology was a fitting corollary to liberal Christianity's embrace of modernity, its insistence on the transformative power of Christ's teachings, and its focus on eradicating social oppression.

In recent years, some scholars have questioned Twain's inclusion in the realist school of American literature, and the concept of "homiletic realism" both acknowledges Twain's contribution to the genre while taking seriously its critique of truth through "strategies of surprise and disruption, challenging cultural self-delusion and narrative convention." ${ }^{, 97}$ Gregory S.

Jackson's definition of homiletic realism is a useful entrance point into Twain's own liberal aims in Huckleberry Finn. Jackson writes that the genre "posited a radical, modern imitatio Christi as a transformative structure of identification with the oppressed. In so doing, it sought to weaken the link between the agent's capacity to represent social oppression and his or her moral complicity in it." 98 This identification with the oppressed in and through Christ is essentially a literary iteration of Bushnell's moral influence theory of atonement. In both-one from the

97 Bruce Michelson, Mark Twain on the Loose: A Comic Writer and the American Self. Amherst: University of Massachusetts, 1995. 6. For a more detailed discussion of Mark Twain's use of realism in Huckleberry Finn, see Michelson's chapter titled "The Quarrel with Romance." Also see: Michael David Bell, The Problem of American Realism: Studies in the Cultural History of a Literary Ideal. Chicago: University of Chicago, 1993. 44-57.

98 Gregory S. Jackson, The Word and Its Witness: The Spiritualization of American Realism. Chicago: University of Chicago, 2009. 8. This characterization of Adventures of Huckleberry Finn also speaks to the ways in which critics have haphazardly and incorrectly accused Twain of endorsing racism, simply by portraying it in a realist mode. To confuse representation with endorsement is simply poor scholarship, at best. 
pulpit, one from the pen - the focus is on Christ's transformative power over humanity as part of humanity. By identifying with Christ as a human, by participating metaphorically in his sufferings, believers were encouraged to move closer to their suffering members of society; and similarly, Jackson writes that Christian fictional texts utilized homiletic fiction to depict and process the "turbulent social change" and "suspicions of language's capacity to represent a stable, unified meaning" by calling for social change. ${ }^{99}$ Certainly Twain helped lead this movement. But unfortunately Jackson's selection of texts reveal a far too narrow definition of "religious" fiction, and exclude Twain while ignoring the unprecedented shifts in theology that took place in the late half of the nineteenth century.

However, if one broadens this definition of "religious" to accommodate writers who espoused Christian Liberalism—a growing movement at the time—Jackson's discussion of homiletic realism helps place Twain at the center, rather than on the margins, of the nineteenth century's movement toward socially minded texts. Toward this end, it is worth looking at his discussion of the three main components of homiletic realism, in detail: First, Jackson states, "homiletic texts employed allegorical frames to create social environments immediately present to readers... in which individuals imagined possibilities for personal transformation." ${ }^{, 100}$ These allegorical frameworks also sought to "transform individuals into communities of action" as the tales had "realities and consequences both in historical and eschatological time." ${ }^{.101}$ Second, homiletic texts "denied the reader the role of passive onlooker," instead demanding "their narrative participation and volition in moral choices." ${ }^{\text {102 }}$ The texts require, Jackson argues, that readers "identify with the subjects of the texts, to engage in a dialogue not only about his or her

99 Ibid, 9.

100 Ibid., 31.

101 Ibid.

102 Ibid., 31-32. 
decisions and choices but also about their implications for personal experience and social obligation." 103 And third, Jackson writes that "homiletic novels... illustrate the injunction that the faithful become Christlike by becoming a 'living sacrifice' for the social world — the homiletic catechism of muscular Christianity."

Certainly Adventures of Huckleberry Finn illustrates all three of these concerns of homiletic fiction and is an exemplary study of the homiletic mode in the post-Civil War era. Twain's tale is a powerful allegory for American society, for the church, and for the shadow of slavery as it pervaded the decades following the institution's end. As I will demonstrate, the novel also seeks personal and social transformation among America's Christian public by inviting readers to engage in Huck's various moral choices and dilemmas. Twain denies readers the passive role, Jackson speaks about, and, in doing so, Twain's text works to engender personal sacrifice on the part of racial equality. But because Twain's characterization of imitatio Christi adopts a more liberal theological vision —-focusing on the ability of human will to enact Christ's teachings, rather than requiring humans to summon God's divine power to act-Huckleberry Finn has not been included alongside other examples of homiletic fiction. The reality is, however, that Twain pioneered a form of homiletic realism that drew on Bushnell's doctrines of liberal theology and sought to challenge the "moral complicity" of American Christianity, one individual at a time. This "realism" was a both/and strategy that critiqued organized religion, which Twain despised and mistrusted, even while it visualized the social transformations possible through genuine faith. The genre of homily also allowed Twain to adopt the role of

103 Ibid.

$104 \mathrm{Ibid}, 31-32$. In this helpful introduction to his book, Jackson does discuss the link between homiletic fiction and the eventual development of the Social Gospel movement, to which I think Twain and others in this study were precursors. 
preacher - a role he so relished - to condemn the racial injustices of the Reconstruction Era. ${ }^{105}$

He was a Missourian transformed, living in the liberal conclave of Nook Farm in Connecticut, and bringing his "calling to literature" to bear on one of society's greatest forms of oppression. Slavery had been federally outlawed decades earlier, but its long shadow stretched out in deep, violent racism and systematic disenfranchisement of African Americans. According to Twain, American Christians were either directly sanctioning this discrimination or taking part in the "lie of silent assertion" by burying their heads in an apolitical Christianity easily propagated by Moody and his cohort. ${ }^{106}$ As Twain said years later, during a public reading of Huck Finn, a "sound heart is a safer guide than an ill-trained conscience [which] can be trained to approve any wild thing you want it to approve."107 America—Christian America—had lost its conscience and abandoned the centering morality it still purported to represent. Twain laid bare the paradox. There are myriad examples of homiletic realism in Adventures of Huckleberry Finn, but this study will address two primary ways that Twain's novel reflects and refracts the teachings of liberal Christianity in his fictional homily: his relentless interpolation of the doctrine of Providence and his veiled inclusion of the doctrine of atonement through two biblical texts (voiced through the characters of Jim and Uncle Silas) that actually scaffold Twain's overall

105 Twain often characterized his talks or lectures as "sermons." In a letter to his brother Orion in 1865, he began, "And now let me preach you a sermon..." (Mark Twain Project, 19 \& 20 Oct. 1865). Again, at a dinner in St. Louis in 1902, a reporter who attended the event stated that, "In a little speech at the end he [Twain] said that he wanted to preach a sermon, since he was as reverend as anybody" (Ensor, "A Clergyman Recalls Hearing Mark Twain," 6). Other such examples abound. In an 1871 essay, Twain also likened artistic professions (such as he was engaged in) to that of preaching, stating that "We are all instruments for the carrying out of God's purposes." The essay was a defensive of George Holland, who, as an actor, was denied a church funeral and burial. In response, Twain asked, "Where was ever a sermon preached that could make filial ingratitude so hateful to men as in the sinful play of 'King Lear'? ... Ministers are not the only servants of God upon earth, nor His most efficient ones either, by a very, very long distance! Sensible ministers already know this, and it may do the other kind good to find it out" ("The Indignity Put Upon the Remains of George Holland by the Rev. Mr. Sabine" 51$52,55)$.

106 Twain qtd. in Geismar, 212.

107 Twain qtd. in Gregg Camfield, "Mark Twain and Amiable Humor," A Companion to Mark Twain. Ed. Peter Messent and Louis J. Budd. Malden, MA: Blackwell, 2005. 506. 
message. Ultimately the liberalized versions of these two doctrines portray American Christianity as apostasy. True morality required one to "play double"- to deny prevalent church teachings on race and instead pursuing the morality of imitatio Christi. In true Twainian style, the novel is best understood from back to front, as Uncle Silas, himself a preacher, unwittingly and ironically pronounces judgment on the American church through his sermon text, and thereby provides the key with which to interpret Twain's tale. The glance backward also allows the novel to read like an updated biblical text—moving from Old Testament law to New Testament grace (both slanted but still identifiable representations), as Huck becomes the ultimate "Pilgrim" progressing through America's theological missteps. Throughout, the tale is brimming with examples of theology questioned and then remade. There are religious impersonators, revival meetings, sermons, and allusions to sin, heaven, and hell. Taken together with Twain's liberal, homiletic mode of realism, his critique of religion testifies to dramatic theological shifts in post-Civil War America and assails American readers for their backward, legalistic stance on a Christianity that endorses racial oppression.

In Huckleberry Finn's opening pages, Twain introduces the notion of American Christianity's "two Providences"- two outlooks on the nation's relationship to God, based on specific theological views of God's character and his desire for human morality. Huck's characterization of Providence provides not only a "thematic form" for the novel, as one scholar suggests, but also frames the tale as a pseudo-biblical text, where duty to the law is replaced with the freedom of living in an era of Christian grace. ${ }^{108}$ Huck comments: "Sometimes the widow would take me one side and talk about Providence in a way to make a body's mouth water; but maybe next day Miss Watson would take hold and knock it all down again. I judged I could see

108 Edgar M. Branch, "The Two Providences: Thematic Form in 'Huckleberry Finn."' College English 11.4 (1950):188-195. 188. 
that there was two Providences, and a poor chap would stand considerable show with the widow's Providence, but if Miss Watson's got him there warn't no help for him any more."109 Here, just as the "adventures" begin, Twain establishes the novel's main question, itself a direct echo of the era's theological debates: What is the essence of God's relationship to human beings and to human history? Does moral action emanate from loving devotion to a caring God, or is it a response to fear of divine wrath? Certainly, both Widow Douglas and Miss Watson take seriously the bible's exhortation to "train up a child in the way he should go," but they approach God's character in disparate ways. ${ }^{110}$ Through their training, Huck becomes a metaphor for how one's learned, moral instruction plants the seed for future moral action.

Represented are two theological stances on the nature of God: the juridic tradition and the philanthropic model. Miss Watson's stern conception of Providence is a mouthpiece for America's Calvinist past — an understanding of God and salvation that dominated church teaching prior to the Civil War (and constituted Twain's own theological schooling as a child). This was a view of God as righteous judge, as one who returns blessing for blessing, but also cursing for cursing: a God who demands strict adherence to his laws, or else. ${ }^{111}$ Conversely, the

109 Twain, Adventures of Huckleberry Finn, 14.

110 Proverbs 22:6, KJV. Child raising, in fact, becomes intertwined with discussions of Providence and morality in Adventures, and it seems quite possible that Twain was influenced by Bushnell's widely popular book Christian Nurture.

111 In many ways, nineteenth-century debates about God's Providence were inherited from earlier, Puritan notions about God's character and fell along Old Testament and New Testament divides. The concept of God as righteous judge traces its foundation to the books of Genesis, Exodus, Leviticus, and Deuteronomy, where God promises, in covenantal relationships, that he will bless those who follow him and curse those who turn away from his commandments. From America's founding onward, many Protestants believed themselves to be grafted into these Mosaic and Abrahamic covenants, as the United States was also a "chosen people" of God. Conversely, some American Christians, especially more liberal believers in the latter decades of the century, emphasized God's "new covenant" as expressed in Christ in the New Testament. This covenant of grace came through Jesus's sacrifice - the atonement — and provided a new understanding of God as one who dealt with humankind according to love, forgiveness, and mercy. A second, crucial nineteenth-century debate also emerged as a corollary to God's Providential design: disagreements about predestination and free will, which found expression in Calvinism and Arminianism, respectively. Twain ardently denied Calvinism's teachings of predestination and insisted that an emphasis on free will and individual moral choice was the only way to combat injustice. For broader discussions on American Calvinism and Arminianism, see Mark A. Noll, America's God: 
Widow Douglas's Providence represents liberal theology's emerging philanthropic understanding of God's character, where forgiveness and Christ's humanity are emphasized. Theologically, the former approach to Providence portrayed God as an "emotionally complex" being, whose ultimate goal was justice, and who dealt with humans according to his love and righteous anger; the latter emphasized God's love for his creation (as evidenced through Christ's sacrifice) and insisted humankind replicate this love for one another. Thomas Jenkins calls this move from the juristic tradition to philanthropism a "massive shift in how theologians understood... God's character," underscoring that "the middle of the nineteenth century was the crucial era of debate about this doctrine."112 The end of the Civil War intensified these questions, as Americans in the North and the South sorted out what victory or defeat meant in regard to God's divine purpose for the nation. Had He dealt with America according to justice, by sanctioning the war? Could his love for humankind have interceded on the part of the slaves? Was it still possible to collapse the nation's destiny into God's design and Providential plan? And could God's ways even be discerned by a nation so deeply flawed? In his 1865 commencement address at Yale, Bushnell himself asserted a somber notion of Providence, folding mid-century discussions about moral action into the conversation about divine design: "In these rivers of blood we have now bathed our institutions, and they are henceforth to be hallowed in our sight. Government is now become Providential — no more mere creature of our human will, but a grandly moral affair." 113 In this historical context Providence is not simply an ethereal reference to God's essence or his

From Jonathan Edwards to Abraham Lincoln. Oxford: Oxford UP, 2002; or, Holifield, E. Brooks. Theology in American: Christian Thought from the Age of the Puritans to the Civil War. New Haven: Yale UP, 2003. For discussions on Twain's own views of Calvinism, free will, and free thought, see: Berkove and Csiscila. "Twain's Countertheology," Heretical Fictions: Religion in the Literature of Mark Twain; Bush, "Mark Twain's Roots," Mark Twain and the Spiritual Crisis of His Age; and Noll, "The Crisis over Providence," The Civil War as Theological Crisis.

112 Thomas E. Jenkins, The Character of God: Recovering the Lost Literary Power of American Protestantism. New York: Oxford UP, 1997. 26-28.

113 Horace Bushnell, Building Eras in Religion. New York: Charles Scribner's Sons, 1881. 328-329. 
foreordained plan for the nation. Rather, in the post-War era, concepts of Providence reached down to every day human life on earth, shaping each individual's sense of morality and determining right action. Twain places Huck squarely in the center of this new theological landscape.

As Huck receives competing narratives on Providence, he is faced with his own crisis of belief. Miss Watson tells him to "pray every day" and he'll get whatever he wants; but Huck tries this technique and is quickly discouraged when he fails to get the new fish hooks for which he prayed. ${ }^{114}$ In response, Miss Watson deems him a "fool," but the widow corrects him gently, saying he must, instead, pray for "spiritual gifts" by which to help others. Huck states, "She told me what she meant-I must help other people, and do everything I could for other people, and look out for them all the time, and never think about myself." These dueling views on Providence create a conundrum for young Huck, as he goes to the woods to turn "it over in [his] mind a long time," and finally concludes: "I thought it all out, and reckoned I would belong to the widow's [concept of God], if he wanted me."115 This exchange may at first seem minor in the overall plot of the novel, but the model of "Providence" Huck chooses in this moment shapes his sympathy for Jim and justifies his moral actions later in the story. Not only does Widow Douglas espouse a philanthropic view of God, but her characterization of lived theology is one in which

114 Huck's innocent, if misguided, use of prayer is a reiteration of Twain's own experiences as a child. In his autobiographical dictation for August 15, 1906, he reflected on how his first schoolteacher, Elizabeth Horr, had instructed the children that "whosoever prayed for a thing with earnestness and strong desire need not doubt that his prayer would be answered." Twain reveals that he had prayed for gingerbread, and then, in Sherwood Cummings's words, Twain "gratefully accepted the gingerbread that a neighboring student had negligently left within reach." Twain then reflected that prayers were never "competent to life that gingerbread again [but] if a person remains faithful to his gingerbread and keeps his eye on it, he need not trouble himself about your prayers." But, privately, Twain expressed the pain of this moment of disillusionment, even as a child: "Why should one laugh at my praying for gingerbread when I was a child? What would a child naturally pray for?--a child who had been lied to by teachers and preachers and a lying Bible-text? My prayer failed. It was 65 years ago. I remember the shock yet. I was as astonished as if I had caught my own mother breaking a promise to me." See: Sherwood Cummings, Mark Twain and Science: Adventures of a Mind. Baton Rouge: Louisiana State UP, 1988. 18-19.

115 Twain, Adventures of Huckleberry Finn, 14-15. 
compassion, selflessness, and intercession on behalf of others is paramount. Hers is a practical Christianity, where one's own actions must be determined by subjective assessment of the needs of others and by a willingness to act—even to sacrifice—-for someone else.

Indeed it is this practical outgrowth of belief that demonstrates Twain's immersion in Christian liberalism, Unitarianism, and the Hartford Circle as he wrote the novel in the 1870s and early 80s. One can hear echoes of Bushnell's theory of atonement when the Widow instructs Huck to submit to "Providence," "help other people," "do everything [he] could for other people," and "never think about [himself]." Here also, is Twain's "Sacred Personage" at workwithout need for divine power or metaphysical interaction of the Spirit. Huck embraces a practical morality, where one's individual human will follows the selfless Example, on behalf of others and their wellbeing. This post-War desire for a "practical savior" was also heralded by an 1885 editorialist for the Christian Index, who argued, "The Lord Jesus was not a mere enthusiast, nor a mere theoriser. He was a practical man... He taught strange theories... but they were theories of great value in practical application. ${ }^{, 116}$ In name, such an outlook reflects Christian Liberalism's embrace on the "moral influence theory" of atonement—a concept made popular by Bushnell and heralded by Twichell. In what Twain called the "moral emergency" of post-Civil War America, there needed to be a standard by which racial injustice could be overcome, and practical imitation of Christ's sacrificial act often meant going against Church teachings. ${ }^{117}$ While Huck seeks to follow the Widow's exhortation always to "help other people," a concept that aligns (likely unbeknownst to Huck) with Jesus's teachings, its implementation could

116 "A Practical Saviour." Christian Index 65.52 (24 Dec. 1885): 8. Many other editorials and articles from the time use similar language to call for "practical" faith or "practical" Christianity.

117 Twain qtd. in Victor Fischer and Lin Salamo. "Foreward." Adventures of Huckleberry Finn. Berkley: University of California, 2001. xxi. Twain used this phrase in his "morals" lecture, given in 1895, in which he read from Chapter 16 of Huckleberry Finn and prefaced the reading with his own "proposition" for the book's message. He famously stated: "In a crucial moral emergency a sound heart is a safer guide than an ill-trained conscience" (qtd. in Camfield 506). 
potentially contradict church teachings. But, as Huck later illustrates, fidelity to Christ's Golden Rule could make a powerful stand against racist church dogma - a conviction Twain himself believed. Writing in an 1871 editorial, Twain argued, "All that is great and good in our particular civilization came straight from the hand of Jesus Christ, and many creatures, and of divers sorts, were doubtless appointed to disseminate it. ... Whosoever, in his way and according to his opportunity, sows the one and produces the other, has done high service and worthy." 118 Ultimately, Twain states, "We are all instruments for the carrying out of God's purpose." ${ }^{119}$ For Huck, the Widow Douglas's understanding of Providence is an expression of this practical message of Christianity, and he chooses to follow that path, rather than withstand the compulsory edicts of Miss Watson's Providence.

Huck's choice comes with an immediate cost. As he wends down the river to a new life, he soon encounters Jim and grasps the great paradox of American Christianity: if God desires for him to sacrifice his own wellbeing and "do everything he could" for others, he will be at odds with the supposedly Christian society that makes it illegal for him to help Jim, a runaway slave. Huck keeps his own code, regardless, and agrees not to report Jim, pledging, "People would call me a low-down abolitionist and despise me for keeping mum—but that don't make no difference. I ain't going to tell." ${ }^{\prime 20}$ Since Huckleberry Finn's publication, scholars too numerous to count have examined this and other episodes of what they call Huck's "moral dilemma" regarding Jim's escape - from his tender apology to Jim in Chapter 15, to the genuine affection he feels toward him in Chapter 19, and for his realization of Jim's emotions as a fellow human being in Chapter 23. But the moral dilemma of the novel cannot be understood fully apart from Twain's

118 Mark Twain, “The Indignity Put Upon the Remains of George Holland by the Rev. Mr. Sabine.” What is Man? And other Philosophical Writings. 1871. Berkley: University of California, 1963. 53, 51.

119 Ibid.

120 Twain, Adventures of Huckleberry Finn, 52-53. 
subversive deployment of Christian Liberalism to confront American Christianity's sham.

Rather than simply condemning Christianity in its entirely, Twain repeatedly lays out the "two Providences" in order to examine the ways that Christian moral action have been corrupted and ways it can be made right again. Without wading into denominational debates, weighing doctrinal scuffles, or even mentioning Jesus by name, Twain reminds his Christian audience of what Dietrich Bonhoeffer would many years later call the "cost of discipleship": the knowing acceptance of "costly grace" which "calls us to follow Jesus Christ. It is costly because it costs a man his life, and it is grace because it gives a man the only true life." ${ }^{\prime 21}$ For Twain, the example of the Sacred Personage was the heart of the Christian message and following it is man's ultimate task, as well as his strongest method of preaching to his fellow man. ${ }^{122}$ The philanthropic model of Providence is not a passive morality, the novel proclaims, but (in the words of O'Connor) is a "startling" commitment to those who are the least in society. Or, as Huck remarks in his most fraught moment of moral action: "As long as I was in, and in for good, I might as well go whole hog.,"123

To depict the ways in which the Sacred Personage's message had been muted by a loud, corrupt, and white supremacist American church, Twain continually draws attention both to speech and silence as two forms of moral intervention. Both are actions, Twain insistsreminding readers that the "lie of silent assent" is just as poisonous to freedom as the loudest verbalized "amen." 124 Heidegger writes that silence is "an essential possibility of discourse," and, while it includes no instructions or advice, it holds "the articulative discourse belonging to

121 Dietrich Bonhoeffer, The Cost of Discipleship. New York: Macmillan, 1959. 47.

122 In a 1902 address, Twain quoted a passage from St. Francis of Assisi, indicating that a life lived in joy and kindness is, itself, akin to preaching a sermon. The episode is recounted in Ensor's "A Clergyman Recalls Hearing Mark Twain," 6.

123 Twain, Adventures of Huckleberry Finn. 271.

124 Twain, "Lies and Civilization." 212. 
wanting to have a conscience." ${ }^{125}$ As a rhetorical tool, silence can obscure, close off, and redirect behavior, and realizing this is part of Huck's training in a socially-situated incarnationalist theology. In some scenarios, Huck finds that silence is a way to protect what is good, right, and precious to him. ${ }^{126} \mathrm{He}$ encounters slave catchers, townspeople, performers, preachers, and general acquaintances whose prejudices require him to "keep mum" about Jim's whereabouts. In one case, Huck protects Jim by keeping mum as slave catchers on the river incorrectly surmise that his traveling companion has smallpox and, therefore, neglect to check the raft for runaways. Huck goes along with their story and, by remaining silent, allows Jim to proceed down the river unharmed. ${ }^{127}$ In this scene of Chapter 16 , Huck wrestles with his decision to stay silent, at first chastising himself for not setting things straight with the slave catchers, but then acknowledging that he would "feel bad-I'd feel just the same way I do now" if he had verbalized the truth. ${ }^{128}$ Confused and seeing no clear iteration of Providence, Huck muses: "What's the use you learning to do right, when it's troublesome to do right and ain't no trouble to do wrong, and the wages is just the same? I was stuck. I couldn't answer that."129

At times silence is Huck's assent to immoral behavior, and, realizing this as an immoral action of its own, Huck says he feels "bad and low," "ashamed of the human race," and "ornery and low down and mean." ${ }^{130}$ In one such instance he understands that the Duke and Dauphin (the Royal Nonesuch) will swindle the Wilks family out of an inheritance, but fails, twice, to intervene. At first he simply states, "I see what he was up to; but I never said nothing, of

125 Martin Heidegger, Being and Time: A Translation of Sein und Zeit. Albany: State University of New York Press, 1996. 273.

126 For a good discussion on Huck's melancholia, loneliness, and self-isolation (though, surprisingly, not a discussion on Huck's literal use of silence), see: Forrest G. Robinson, "The Silences in Huckleberry Finn." Nineteenth-Century Fiction 37.1(1982): 50-74.

127 Twain, Adventures of Huckleberry Finn. 125-127.

128 Ibid., 127.

129 Ibid., 127.

130 Ibid., 127, 210, 225. 
course." ${ }^{\prime 31}$ And then, when the Wilks discover they have actually been "fooled and lied to," Huck keeps quiet about his own decision to "steal" the money and return it to them, saying that, at the time, he could find "no safe way to chip in and change the general tune."132 Later, in Chapter 42, when Jim is recaptured and treated harshly by the townspeople, Huck indulges his fear and states, "I reckoned it warn't best for me to mix in." ${ }^{, 133}$ Here, again, Twain reminds readers of the danger of "silent assent" - of allowing injustice to proceed without interruption. Just as Huck refuses to "mix in," apolitical Christians were shirking their duty to intervene on the part of their black brothers and sisters being mistreated and denied their rights in the South.

Two of Twain's most striking uses of silence come in response to Jim's escape and they illustrate an active rejection of American "Christian" morality in exchange for a higher order: first, when Huck debates whether or not to disclose Jim's whereabouts and, second, when Jim is abused by the townspeople who have recaptured him. In what is likely the most scrutinized scene of Adventures of Huckleberry Finn, Huck learns that Jim has been betrayed by the Dauphin for forty dollars and is being held as a runaway slave. Huck debates writing a note back to Miss Watson, Jim's owner, to disclose his whereabouts, reasoning that if he had "got to be a slave" it was better for him to be with his family. ${ }^{134}$ But doing so will mean "everything [is] all busted up and ruined" for their journey, and he knows Jim will be denied the freedom he most desires. ${ }^{135}$ The scene is an agonizing one, and, while its realism may not resonate with current readers, in its historical context, as slavery had just ended and America's laws and social customs were still reeling to accommodate emancipated black Americans - now citizens - readers would have 
understood why Huck “couldn't see no way out of the trouble.",136

It is in this dilemma that Huck once again confronts the theological notion of Providence as the centering force of morality. He weighs his inclination to selfishness against his duty to be selfless, and he debates what decision would be "the right thing and the clean thing" to do. ${ }^{137}$ The passage echos Huck's early entanglement with "two Providences," but this time his quandary reveals a disturbing disconnect between what he feels is the right action (the moral influence) and what American Christian society tells him is the right action. Huck's compassion for Jim — a manifestation of Christ's love and the Widow's "do everything you can for others" view of Providence - only makes him feel guilty, as he believes this compassion to be a weakness and, worse, a sin:

At last, when it hit me all of a sudden that here was the plain hand of Providence slapping me in the face and letting me know my wickedness was being watched all the time from up there in heaven... and now was showing me there's One that's always on the lookout [...] I about made up my mind to pray; and see if I couldn't try to quit being the kind of boy I was, and be better. So I kneeled down. But the words wouldn't come. Why wouldn't they? It warn't no use to try and hide it from Him. Nor from me, neither. I knowed very well why they wouldn't come. It was because my heart warn't right; it was because I warn't square; it was because I was playing double. I was letting on to give up sin, but away inside of me I was holding on to the biggest one of all. I was trying to make my mouth say I would do the right thing and the clean thing, and go and write to that nigger's owner and tell where he was; but deep down in me I knowed it was a lie — and He

136 Ibid.

137 Ibid. 
knowed it too. You can't pray a lie-I found out. ${ }^{138}$

To this point in the novel, Huck has accepted the fact that moral action may sometimes require legal transgression, but in this moment he confronts a reality of Reconstruction era Christianity — that, at times, moral action may also require spiritual transgression. While he believes there's "One that's always on the lookout," Huck still wrestles with the concept of "sin," and vacillates between a subjective notion of morality and a prescriptive view of sin and righteousness. This is why he believes he is "playing double," with his efforts to "give up on sin" and his unwillingness to let go of "the biggest one of all"- - his enduring sense of duty toward Jim as a fellow human being.

Here again, we must note the influence of Christian Liberalism on Twain's concept of objectively perceived truth, or at least truth as defined by the American Church. Indeed Bushnell himself questioned the concept of sin as something so "perfectly unambiguous" as to be "regarded as literal." 139 In his discussion on the poetic nature of language Bushnell states that it is "impossible that mere use should have given [a word of thought] an exact meaning, or made it the literal name of any moral or intellectual state." ${ }^{140}$ To illustrate this point, in the next sentence he writes: "The word sin is of this description, and most persons seem to imagine that it names a given act or state, about which there is no diversity of understanding. Contrary to this, no two minds ever had the same impression of it." ${ }^{141}$ Instead, Bushnell says that such concepts as "words of thought" have very subjective meanings, culled through time and experience by each individual:

The whole personal history of every man, his acts, temptations, wants, and repentances;

138 Ibid., 269.

139 Horace Bushnell, God in Christ: Three Discourses. New York: Charles Scribner's Sons, 1876. 47. 140 Ibid., 47. 141 Ibid. 
his opinions of God, of law, and of personal freedom; his theory of virtue, his decisions of the question, whether sin is an act, or a state; of the will, or of the heart; in fact, his whole theology and life will enter into his impression of this word sin, to change the quality, and modify the relations of that which it signifies. ${ }^{142}$

In describing Huck's dilemma with sin, Twain demonstrates this signifying nature of words and the subsequent instability of truth. When Huck, at first, decides to betray Jim, he says he feels "good and all washed clean of sin for the first time I had ever felt so in my life."." But his notion of "sin" is not consistent with his "opinions of God, of law, and of personal freedom," in Bushnell's terms. Huck's theology, then, is a mosaic of beliefs and experiences. It is comprised of his notion of "do unto others" Providence, as well as the moments he spent with Jim on the raft, eating, sleeping, laughing, floating, and watching the moonlight over the river. While the definition of "sin" as handed to him by American Christianity implies that he should "go to hell" for helping Jim get his freedom, Huck appeals to what Twain, in 1906, called "the Christian code of morals" and stands up for Jim. ${ }^{144}$

For Twain, then, it was not only Huck who had "to decide, forever, betwixt two things," but also American Christianity which was caught between its promise to "look out for others" and its desire to forget the racial tumult that precipitated the War. As he penned the novel in the 1870s and 80s, African Americans were "effectively re-enslaved" through sharecropping,

\section{Ibid.}

143 Twain, Adventures of Huckleberry Finn, 269.

144 Twain qtd. in Bush, 159. The quote comes from a speech Twain gave at Carnegie Hall on January 22, 1906, in support of Booker T. Washington's Tuskegee Institute. Bush acknowledges that "Twain can be accused of merely giving the audience what they wanted to hear," but goes on to discuss Washington's warm impression of Twain and the novel Hucklberry Finn, itself. Washington remarked that one could not "read [Huck Finn] closely, however, without becoming aware of the deep sympathy of the author in 'Jim' . . I cannot help feeling that in this character Mark Twain has, perhaps unconsciously, exhibited his sympathy and interest in the masses of the negro people." As a result, Bush concludes that "perhaps, as Twain's 1906 speech suggests, it was this sympathy, a mystical social bond rooted in biblical theology, that should be understood as the center of Twain's version of the Social Gospel" (158-160). 
lynchings, the convict-lease system, and Jim Crow laws; through Huck's dilemma, Twain locates "both the dream and the denial of the dream, both the spectacular boldness of the promise of liberty and justice for all, and the nation's spectacular failure to make that promise a reality."145 The "dream" and the "promise" were, in essence, left to fail by so many white Christians who had, in the antebellum years, championed the end of slavery and ardently participated in the abolitionist movement. After the War, "many of the Protestants who had once guided national life retreated from efforts at shaping society in order to cultivate private gardens of inward spiritual development." ${ }^{, 146}$ Still other Christians flocked toward the reunionist gospel propagated by Moody and revivalists like him who "called for the rejection of the civic nationalist imagination," "denounced religious involvement in politics," and "accepted racial segregation." 147

For this reason, Twain places Christianity at the center of his invective and creates Huck as a stand-in similar to John Bunyan's Everyman. The "lie of silent assent" was the lie of American Christianity, particularly after the War: believers either clung to a corrupt view of Providence through which they continued to oppress, disenfranchise, and mistreat blacks, or, even more commonly, they remained silent on matters of race and, in doing so, were themselves "praying a lie" and abandoning African Americans in their time of need. Notably, it is "Providence" that slaps Huck in the face, as this reference allows Twain to pose the ultimate question to his post-Civil War readers, already attuned to Providential theology: was it "right" and "clean" for Huck to help an African American, and put Jim ahead of himself as his Christian moral duty, or was doing so actually a sin? Indeed, Twain even puts a finer point on his

145 Shelley Fisher Fishkin, Was Huck Black? Mark Twain and African-American Voices. New York: Oxford, 1993. 74. 146 Noll, 53. 147 Blum, Reforging, 119. 
indictment when Huck laments being "brung up wicked" then quickly and ironically adds that he could have gone to "the Sunday School" where "they'd a learnt you... that people that acts as I'd been acting about that nigger goes to everlasting fire."148 Only on the margins, as two scalawags floating down a river away from society and beyond the church's reach, could "Huck and his brown comrade share bed and grub with growing mutual trust" and thereby "resist the rising tide of Jim Crowism."149

To contrast the sham of American Christianity and its silent lies, Twain chooses to portray Jim's own silence as an iteration of the Sacred Personage. In an often overlooked passage in Chapter 42, Twain describes a group of local farmers who have formed a mob and call for Jim to be hanged for running away. Huck watches as they parade him into the house, where his subsequent abuse and treatment not only parallels that of late nineteenth-century lynch mobs, but is strikingly reminiscent of Jesus before his crucifixion: "They cusssed Jim considerable... and give him a cuff or two, side the head, once in a while, but Jim never said nothing. ... [They] chained his hands, too, and both legs, and said he warn't to have nothing but bread and water to eat." The image echoes a passage from Mark 15, in which Jesus is bound and taken before Pilate and the chief priests. In response to their accusations, Jesus twice "answered nothing." "150 Jim's silence, then, is more than the absence of speech or a refusal to speak on his own behalf. It is, rather, an acknowledgement of the skewed moral system which supports and justifies his accusers' attacks, and it points to their own wickedness and corruption. Further, Jim's willingness to "say nothing" aligns him with Jesus, who believed his own suffering and sacrifice was misunderstood by the mobs who surged against him. And just as Jesus gave up his life as a

148 Ibid., 269.

149 Budd, 103.

150 Mark 15:3-5. Later in the chapter, the description of Jesus being beaten and mocked also parallels the description of Jim's mistreatment. 
sacrifice for those who "knew not what they did," Jim had just sacrificed himself to help Tom, "resking his own freedom," as the doctor testifies, and perhaps his life for the incorrigible (white) boy. ${ }^{151}$

Jim's silence also signals his awareness of the situated and subjective nature of truth. As a black, runaway slave - as property - his word is essentially worthless against white citizens who make the laws, interpret the scriptures, and set social practice according to racist, whitesupremacist ideologies. This was true in the days of slavery, but just as true, Twain submits, in the postbellum years. Even a Christ figure like Jim, because he was black, would be tried and convicted by a bloodthirsty host of citizens and the American "chief priests" who make their own laws and meet out their own justice. As Ariela Gross notes, during and after Reconstruction - squarely in the time when Twain wrote and published Huckleberry Finnwhite Southerners continuously sought to "reduce ex-slaves to their prewar status of subjugation," since slavery itself "could no longer be relied on to maintain white supremacy.",152 Instead, "new practices such as vigilantism, terror, and lynching arose" to keep African Americans in a "subordinate position." ${ }^{153}$ Essentially, when it came to having a voice, there was little difference whether a black American was a slave or a citizen, because in either case he was overpowered and silenced by white "legal" proceedings. For this reason, it is the doctor, a white man, who must speak for Jim and declare that he "ain't a bad nigger," while proceeding to tell how Jim helped remove the bullet from Tom's leg and ferry him up the river to safety. ${ }^{154}$ Even in this moment of praise, however, Jim is commended for his silence, as the doctor states he "never

151 Twain, Huckleberry Finn, 353.

152 Ariela Gross, What Blood Won't Tell: A History of Race On Trial in America. Cambridge, MA: Harvard, 2008. 75.

153 Ibid., 75.

154 Twain, Huckleberry Finn, 352. 
made the least row nor said a word, from the start." ${ }^{155}$ Jim's recapture, then, exists in the novel almost outside of historical time, one of several scenes where Twain creates a dramatic moment of homiletic realism by linking biblical imagery to both pre-War and post-War racial injustice.

\section{Uncle Silas: Twain's Prophet of American Apostasy}

In an 1845 public debate over slavery, Andover-trained Presbyterian minister Jonathan Blanchard declared: "Abolitionists take their stand upon the New Testament doctrine of the natural equity of man: the one-bloodism of human kind." Blanchard was referring to a verse in Acts 17, which states, “And [He] hath made of one blood all nations of men for to dwell on all the face of the earth." ${ }^{\prime 156}$ The passage was also famously employed by another Presbyterian minister decades earlier, in 1802, when Alexander McLeod included an exegesis of Acts 17 in a sermon that "became a classic biblical antislavery argument. . . regularly utilized by abolitionists." 157 This claim to the "one bloodism" of humanity was, in fact, echoed throughout the American antislavery movement in sermons, essays, poetry, and sentimental fiction alike. In the nineteenth century, Acts 17 became synonymous both with theological endorsement of universal brotherhood and condemnation of chattel slavery. It is no surprise, then, that lifelong, self-identified Presbyterian Mark Twain includes Acts 17 in his own antislavery (or, more accurately, antiracism) "sermon."158 Twain's contemporaries would have understood the reference to Acts 17 in Chapter 37 of Adventures of Huckleberry Finn; and, most importantly, they would have easily perceived the irony in having Uncle Silas Phelps, a minister of the gospel

155 Ibid., 354.

156 Blanchard qtd. in Noll 42-43; Acts 17:26 (KJV).

157 Mason I. Lowance Jr., ed. A House Divided: The Antebellum Slavery Debates in America, 1776-1865. Princeton, N.J.: Princeton UP, 2003. 103. McLeod's sermon "Negro Slavery Unjustifiable: A Discourse" became a touchstone of early nineteenth-century debates surrounding biblical teachings on slavery.

158 Bush writes that, despite Twain's skepticism of organized religion, he carried his church upbringing with him and "throughout the rest of his career, he regularly self-identified as Presbyterian" (26). 
and a slaveowner, say he was "a-studying over my text in Acts seventeen" to prepare for a sermon. $^{159}$

But the significance of Silas's presence in the novel goes far beyond irony, and just a handful of scholars have attempted to address his role in Twain's homiletic tale. For the few critics who have devoted space to Silas's sermon text, there is placid agreement with Allison Ensor's claim that Twain likely alludes to Acts 17:26, which includes the "one blood" discussion abolitionists so favored. Pressing a bit further, Robert D. Arner suggests that Twain may have "meant us to read on, at least to verse 29" where Paul cautions "we ought not to think that the Godhead is like unto gold, or silver, or stone." 160 This, Arner says, was Twain's “indictment against those professing to be Christians who have replaced God with a gold idol, money," and he goes on to name economic gain as the "chief reason" Southerners support slavery in the novel. Each of these assessments are useful, but only on a limited scale. Neither explain why Twain has Silas cite the chapter of Acts 17, nor do they explain why Twain-a man well-versed in scripture, who read the bible through and often made mention of specific passages - so precisely identifies this section of the New Testament by name, as the only direct bible reference in the entire, sprawling novel.

I argue that understanding Silas's role in the context of Acts 17 actually encapsulates Twain's most damning assertion in Adventures of Huckleberry Finn: that American Christians have forgotten their own spiritual emancipation and, by following an "unknown god" have turned their faith into apostasy. This notion undergirds Twain's portrayal of Huck, who struggles to square Christian teaching of Providence with Christian practice, and it casts Jim and other

159 Twain, Huckleberry Finn, 316.

160 Robert D. Arner, “Acts 17 and Huckleberry Finn: A Note on Silas Phelps' Sermon.” Mark Twain Journal 16.2(1972): 12. 12. Phrasing from verse taken from Acts 17.29 (KJV). 
newly freed blacks as most resembling the struggles and hardships of first-century disciples.

While his biblical namesake was enslaved for his faith, it is Silas's faith that justifies his enslavement of other men. For a late nineteenth-century audience this illustrates a distinct characteristic of both antebellum and postbellum Christianity: both had strayed from God's original design, proving that when "slavery fell" the "slavery text remained; the practice changed, that was all." ${ }^{161}$ In other words, because of Silas's (and the nation's) skewed reading of scripture, Jim Crow laws could exist just as easily as slavery; both were based on the same text. Twain's inclusion of Acts 17, then, is a clever hearkening back to biblical exegesis, salvaging what Twain thought was useful to promote social equality. Incorporating the bible text is also a reversal of the popular sermonic style popularized by Moody, Beecher and others in the late nineteenth century, which ventured away from scripture and embraced anecdote, "rhetorical illustrations," and "pulpit stories."162 If Huckleberry Finn is Twain's sermon, Acts was its biblical prooftext.

To illustrate this ultimate message of Twain's novel, some context is required to bring modern readers in line with how his contemporaries would have understood Acts 17. Largely believed to have been penned by Luke, the Apostle, Acts is a compilation of missionary accounts, each detailing the disciples' efforts to spread the gospel in the first century; included are various persecutions they suffered, as well as their encounters with governments and leaders who were hostile to their "radical" message. ${ }^{163}$ The book begins with Jesus's ascension into

161 Twain, "Bible Teaching and Religious Practice," 109.

162 Reynolds, 494 \& 497. The phrase "rhetorical illustrations" is taken from Henry Ward Beecher, while the other two phrases are from Reynolds.

163 Like most biblical texts, there are deep discrepancies regarding the purpose of Acts, and scholarly approaches are often divided into four main camps: that Acts served as an apology (or justification) for the Christian faith in order to spread the gospel, legitimated the Christian faith as compatible with allegiance to the Roman Empire (lest they be accused of conspiring against the authorities, equipped the saints to stand against persecution, and/or extended an apolitical message of redemption which rose above (and was therefore not threatened by) any 
heaven and ends with Paul's dramatic preaching ministry under supervision of a Roman guard. In the chapters between, Acts reveals the cost of bringing the gospel message to "the ends of the earth," but it also depicts a diverse cross-section of new converts, including Jews and Gentiles, men and women, cripples and slaves, Ethiopian eunuchs and Roman soldiers. ${ }^{164}$ Peter gives linguistic expression to this egalitarianism in chapter 10, when he tells a large gathering: "Of a truth I perceive that God is no respecter of persons. But in every nation he that feareth him, and worketh righteousness, is accepted with him." ${ }^{" 165}$ Those who were not accepted—and are struck down, killed, or overpowered in the biblical account —are often those in power, from the Sanhedrin (the highest ruling religious body in Israel) to King Herod. Thus, the book's underlying focus is on what Bushnell called the "transformative" power of Christ, which could triumph over any adversary to save, empower, and bring into fellowship a diverse community of believers. ${ }^{166}$

At its core the book of Acts proclaims a message of freedom — for the slave girl who had been possessed by a spirit, for prisoners in a Roman jail, and even for disciples Paul and Silas, themselves. Oftentimes freedom comes in the form of spiritual emancipation from sin, but in other instances the text references literal, physical freedom, as in Chapter 16 when Paul and Silas are beaten, shackled, and thrown in prison. The two are eventually freed, but only after a miraculous turn of events: God causes a violent earthquake to throw open their cell doors, which causes the prison guard to repent and believe. Then the newly-converted guard washes the Apostles's wounds, brings them to the magistrates, and explains that Paul and Silas are Roman

earthly government or powers.

164 In Acts 1:8, Jesus instructs his disciples that they "shall be witnesses unto me both in Jerusalem, and in all Judaea, and in Samaria, and unto the uttermost part of the earth" (KJV). In more recent translations, the latter phrase was changed to "the ends of the earth" (NIV).

165 Acts 10:34-35 (KJV).

166 See Acts 2:42-47, which describes the "fellowship of believers" in the early days of Christianity. 
citizens and, therefore, have been mistreated under the law. The missionaries are freed, with apologies from the Roman government. In this account, Christ's message and citizenship laws combine to set the captives free.

In Huckleberry Finn's plot, however, it is Uncle Silas who imprisons Jim (though, thanks to Tom's design, the events leading to Jim's freedom are almost as dramatic as the biblical account). For Jim there is no miraculous earthquake from heaven that opens the door of his leanto, nor does his status as citizen protect him from this unlawful mistreatment. ${ }^{167}$ Instead, Silas himself detains Jim, considering him property and proving, yet again, that even the most dedicated follower of Christ could be corrupted by the sham of American theological teachings. Surprisingly, Twain does not harangue Silas Phelps for his role as a slaveowner, but instead portrays him as a genuine Christian whose faith is touched but not invalidated by slavery. Huck calls Silas a "mighty fine old man" whose long prayers before dinner are "worth it," and we learn Silas visits Jim each day to check on him and pray with him. ${ }^{168}$ In fact, Twain's description of Phelps is exceptional in a novel that burlesques Christian practices and parades through a cast of false believers (the Grangerfords, Miss Watson, the Royal Nonesuch who imitate preachers at a revival). It is the character of Silas who quietly illustrates "a more nuanced assessment of those who represent religion." ${ }^{169}$ One gets the sense that Twain, along with Huck, reveres Silas Phelps, and yet even his brand of Christianity cannot set the captives free. Herein lies Twain's radical movement from preacher to prophet. Not only does Twain take "himself seriously as an overseer of the public conscience and [yearn] to set it straight," he also begs Americans to take seriously

167 While Twain sets Adventures of Huckleberry Finn in pre-Civil War days when such "mistreatment" would have been allowed, under property laws, Twain implies that the story could have taken place even after the war, when the Civil War Amendments to the Constitution declared that former slaves were free and equal citizens before the law. The scenario of abuse happened countless times after the War, as blacks were treated much worse than Jim, and lynched throughout the South.

168 Twain, Huckleberry Finn, 316, 288 \& 309.

169 Ibid., 109. 
the doctrines of love and sacrifice the New Testament proclaims. ${ }^{170}$ Without such a radical "reconstruction" of the faith, Silas is the best that Christendom can hope for-a picture of kindness on the surface, but constantly assenting to the lie of silence and inaction regarding racial freedom.

All of this context builds to the most heralded part of Acts - chapter 17, which includes St. Paul's address to the Aeropagus, at Mars Hill. ${ }^{171}$ This location was the cultural and intellectual center of the ancient world — a place significant in Greek mythology and the site where the most gifted orators debated ideas. Paul was brought to these "men of Athens" by Stoic and Epicurean philosophers who were intrigued by his "new doctrine" of "strange things" regarding Jesus and the resurrection. ${ }^{172}$ Paul's subsequent speech is longest of his sermons contained in the New Testament, and here we read his familiar reference to the "one blood of all nations," as well as his condemnation of those who "think the divine is like gold or silver or stone." But just as Twain's phrasing and ideas on race cannot be cherry-picked without context, neither should Paul's words be quoted without a full sense of his message. He opens by acknowledging the Athenians' sensitivities to the divine, but says he finds himself troubled by their altar inscribed "To An Unknown God." Rather, Paul says that, "Whom therefore ye ignorantly worship, him declare I unto you." What follows is a bold outline of who God is and who he is not, and much of the text aligns with Twain's own philosophies about the Creator. ${ }^{173}$ Most importantly, it denies any earthly ownership of God, as Paul argues, "[The] Lord of heaven and earth, dwelleth not in temples made with hands; Neither is worshipped with men's hands, as

170 Budd, 17.

171 Aeropagus is the Greek term for the hill, meaning “Ares's hill," for Ares, the god of war. The location's name was later Romanized to Mars Hill. Its location is near the Acropolis, overlooking Athens.

172 Acts 17:19-20 (KJV).

173 For more on Twain's beliefs about the Creator in relation to science, see Cummings, particularly "Chapter 2 : Strata." 
though he needed any thing, seeing he giveth to all life, and breath, and all things." ${ }^{, 174}$ In other words God exists above any human efforts to encapsulate and own him, something Twain persistently underscored for much of his writing career-from tragic misinterpretations of Christian morality and Providence in Huckleberry Finn to his satirical depiction of heaven in “Captain Stormfield's Visit to Heaven." In each case, Twain "rebuke[d] the smallness of the American concept of God and His Heaven," just as Paul insisted God could not be made by human hands or contained in their houses of worship. ${ }^{175}$

The remainder of Paul's address focuses on humankind's right relationship with God, asserting that "all nations of men" are the "offspring of God." He states that the Creator fashioned from "one blood all nations of men for to dwell on all the face of the earth," and that God did this "That they should seek the Lord, if haply they might feel after him, and find him, though he be not far from every one of us; For in him we live, and move, and have our being; as certain also of your own poets have said, For we are also his offspring." ${ }^{176}$ If allowed to color our understanding of Twain's novel, this passage further elevates any notion of brotherhood between Huck and Jim, because not only are they of "one blood" corporeally, but they are also united as the descendents of God himself. This argument echoes a pervasive abolitionist emblem, which circulated in the first half of the nineteenth century, depicting a slave in chains and asking the question, “Am I not a slave and a brother?" In this context, Twain's allusion to Acts 17 reaffirms the doctrine of Christian brotherhood-something Silas is unwittingly violating. At issue is not whether Twain himself believed that Christians were the brothers and sisters of Jesus and joint heirs of God's salvation; Protestants did. And all across the North and Midwest preachers like

174 Acts 17:24-25 (KJV).

175 Bush, 124.

176 Acts 17:26-28 (KJV). 
Moody called believers "brothers" and trumpeted the need for unification under Christ, but simultaneously "dealt a powerful blow" to "racial inclusiveness" by preaching apolitical sermons and even mandating segregated seating at his revivals. Twain, in contrast, did embrace the concept of racial unity, grounding his belief on the "metaphysical view of all peoples having been created equally by one God." ${ }^{, 177}$ Later in life, Twain would characterize all humans as possessing a "divine spark" which God imparts to man and thereby "lifts us far above the other creatures, \& confers upon us a kinship with God... The divine spark! Think of it—it is ours!ours!—ours! Without it, we're poverty; with it, who can estimate our wealth!" ${ }^{178}$ Taken this way, the divinity infused in each human life would make all races and backgrounds of equal worth and inseparably linked to God himself. Huck and Jim were not just bonded as friends or comrades, Twain suggests, but each harbored a spark of the divine and were, therefore, granted immeasurable and eternal worth.

The final section of Acts 17 could be Twain's ultimate message to American Christianity, as Paul states that, in the past, God merely overlooked such "ignorance," but "now commandeth all men every where to repent: Because he hath appointed a day, in the which he will judge the world in righteousness by that man whom he hath ordained." ${ }^{179}$ Indeed, Huckleberry Finn itself seems like a novel that urges repentance and perhaps even threatens judgment—for a nation that endorsed slavery, for a church that twisted "Providence" in order to abuse blacks, for a "priesthood" of clergy who proclaimed brotherly love and yet were racially divisive, and especially for Protestant Christians who fought for the cause of abolition, then abandoned former slaves just as they attained their freedom. Likely this is why Huck chooses to "light out for the

177 Bush, 151.

178 Twain qtd. in Bush 269.

179 Acts 17:30-31 (KJV). 
Territory," at the novel's close. To stay among "civilization," would be to submit to the code of morality he has come to abhor, and he states, "Aunt Sally she's going to adopt me and sivilize me and I can't stand it. I been there before." ${ }^{180}$ Huck can only hope, like Twain, that "if a good man continues in the direction of enlightenment, his religious practice may, in the end, attain some semblance of human decency." ${ }^{181}$ In the meantime, Twain himself would offer his jeremiad, his homiletic tale of warning, hoping to right the course of a corrupted and nearly unrecognizable Christianity.

\section{Conclusion}

Just as Moody hoped a sermon anecdote would "fasten itself in the hearer's mind, and [bear] fruit," so Twain's Adventures of Huckleberry Finn has done throughout American literary history. Perhaps more than any other novel, it boldly and vividly challenged the landscape of American Christianity in an era when most Northern Protestants were more willing to attend revivals than rallies and believed their work on the part of the slave was complete. But, through Huck, Jim, and Uncle Silas, Twain at once questions America's notion of Providence, asserts the need for a more incarnationalist moral system that emulates Christ's teachings, and laments the corrupt marriage of Christianity and slavery, which laws alone could not tear asunder. Liberty, Twain proclaimed in contrast to Moody's sermon illustration, was neither a sham nor reserved for heaven, but was a very earthly concern—one that should attract the involvement of every Christian who heard Jesus's teachings. Inaction was the real sham, and Christians had fallen into a drowsy post-War slumber.

In his later years, Twain would face unimaginable hardship and express great doubt in

180 Twain, Huckleberry Finn, 362.

181 Twain qtd in Geismar, 110 
God's goodness. But during those burgeoning years in the Hartford Circle, among the founders of Christian Liberalism and in the warmth of his family and friends, the Missouri skeptic found himself in an unlikely role — as preacher to the masses, extolling the possibilities for a racially equitable society. Adventures of Huckleberry Finn must be understood in this context, as Twain's attempt to carve a space of possibility he believed existed for liberal Christianity in the late decades of the century. Like the apostle Paul insisted in Acts 17, Twain held that Americans must face their, as-of-yet, "Unknown God" and reorient themselves to the gospel they so ardently proclaimed. As he wrote in the margins of a book in the late 1880s, even Twain the unbeliever knew that Christianity could be "the very invention of Hell itself," but if lived out in genuine commitment to Jesus's teachings, could be "the most precious and elevating and ennobling boon ever vouchsafed to the world." ${ }^{, 182}$

182 Twain qtd. in Bush, "A Moralist in Disguise," 55. 


\title{
Chapter 2: \\ "The Christ In Us": Charles Sheldon's Social Gospel for Racial Redemption
}

\author{
"To know men at a distance is not to love them as \\ Christ did, for the multitudes thronged him.... \\ The world will be converted by personal touch \\ of soul on soul." \\ — Charles M. Sheldon ${ }^{1}$
}

In 1993, an 84-year-old, African-American Kansas resident named Charles Sheldon

Sudduth was recognized before the United States House of Representatives as an alumnus of the first black kindergarten west of the Mississippi. ${ }^{2}$ Sudduth had been born in 1909 in the frontier state of Oklahoma, then traveled with family to Kansas, to live as part of an enclave of "Exodusters" - slaves who had come West, hoping to find safety from racism, cheaper land, and a chance to start over as citizens. ${ }^{3}$ The transition from Southern slave to Kansas citizen was rife with difficulty, however, and as black emigrants poured into the state, they were met with racial prejudice and a staggering lack of employment, education, and material necessities. But Sudduth's life at the turn of the century also corresponded with an historic melding of progressive reform and social Christianity in his Tennessee Town neighborhood of Topeka. Slowly, incrementally, the community was being transformed, as black and white citizens worked together to establish schools, coordinate job-skill training programs for adults, and orchestrate a variety of "village improvement" initiatives. Sudduth was afforded a space in the local kindergarten, where the teachers "took an interest" in him and "it felt just like home did.", Thanks in part to this early educational foundation and his community's support, Sudduth went

1 Charles Sheldon. "Practical Sociological Studies." The Andover Review 14.82 (Oct. 1890):369.

2 U.S. Congress. House of Representatives. 16 June 1993. 100th Anniversary of the First Black Kindergarten West of the Mississippi River. 103rd United States Congress. H3694-H3695.

3 In an explanatory footnote to her article, Judith L. McConnell writes: "It is not certain where the term 'exodusters' originated. According to Robert Richmond, author of Kansas, A Land of Contrasts (Arlington Heights, IL: Forum Press, 1989), its earliest reference is found in Harper's Weekly, July 5th, 1879. Because the migration of former slaves westward was then at its peak, 1879 became known as the 'Exodus Year'" (20).

4 Sudduth qtd. in McConnell, 15 \& $16 .$. 
on to a life of success and influence himself, making history as the first black foreman on the Santa Fe Railway and, later, owning his own business and serving as Chairman of the Board of Directors at Bayridge College in Texas. On the day Sudduth rose for Congressional recognition, he was not simply a representative of the Tennessee Town Kindergarten, but an embodiment of a forgotten, yet nation-altering chapter in American race relations.

The Tennessee Town Kindergarten Sudduth had attended was founded by his namesake, the Reverend Doctor Charles Monroe Sheldon, early in his pastorate in Topeka. In the passing century, Sheldon's tireless work on behalf of race reform has been largely forgotten, distilled down to the slight size of his religious best seller, In His Steps. But, in truth, Sudduth's life is a more fitting testament to Sheldon's insistence that practical Christian service on behalf of the gospel would "go a long way towards reclaiming a whole community.", As a minister, writer, sociologist, speaker, editor, and reformer, all of Sheldon's efforts were aimed at translating Christian belief into practical social action. He saw his writing "either as something to be used for spiritual uplift" or, more often, "as marching orders for social reform;" he had no interest in lasting literary fame. ${ }^{6}$

But Sheldon did understand the power of the written word, and until the day he died he worked tirelessly to distill the transcendent Word into human stories of transformation. Sheldon

\footnotetext{
5 Charles M. Sheldon, “A Social Experiment.” New York Observer and Chronicle 75.38 (Aug. 1900): 260. Judith McConnell interviewed Sudduth at Washburn University in 1995 and included partial transcripts of the interview in her article published later that year. She tells that, in his thirty-year career on the Santa Fe Railway, Sudduth made history as its first black foreman; afterwards, Sudduth was owner and operator of his own janitorial business forty-seven years. Like his mentor, he also invested his time in educational and ecclesiastical endeavors: Sudduth served as the Chairman of the Board of Directors and on the Board of Trustees at Bayridge College in Kendleton, Texas, he was an ordained deacon in the Church of God, and he toured the country for years as the member of a gospel quartet, singing mostly in white churches and subsequently performing, as he described it, "a lot of race relations programs and [meeting] many instances of segregation" (qtd. in McConnell 18-19). Sudduth hoped his work and service in the community would continue to bring changes to racial inequity - a way of continuing on the path Sheldon helped blaze. For more on Sudduth's life and legacy, see: Judith McConnell, "Kindergarten in Kansas: A View From the Beginning." Journal of Education 177.3 (1995):9-22. 6 Miller, 36.
} 
articulated his vision for progressive, practical Christianity in newspaper columns, journals, sermons, lectures, poems, novels, and conversation with anyone who would listen. Of course the Kansas minister was not alone in employing the entertaining and anticipatory power of literature to draw congregants into a "higher" truth, and many of Sheldon's contemporaries also turned to pulpit storytelling, as discussed in Chapter 1, regarding D.L. Moody. But Sheldon's aim was earthly as well as spiritual, and in his sermon stories he spun extravagant tales of individuals and communities transformed by simple, powerful fidelity to the teachings of Jesus. These aspirational anecdotes were meant to challenge the breadth and depth of his parishioners' vision for their church and community, and the stories were always a call to practical action. To Sheldon, word and deed were inseparable. And like other liberal theologians at the time, Sheldon felt that practical Christianity was only successful if the message of sacrifice and redemption went forth into the world; believers had to venture beyond the church walls to assist their communities—-something liberal theologian Horace Bushnell asserted decades earlier. ${ }^{7}$

Sometimes the printed word could serve as such a mediator as well, and on occasion Sheldon printed his sermons ahead of time to pique interest in an upcoming sermon series. ${ }^{8}$ Or, to spark dialogue on a subject, he would distribute outlines of a sermon and solicit questions from parishioners, promising to answer their inquiries at that Sunday night's service. Most notably during his lengthy tenure at Central Church in Topeka, Sheldon crafted, read, and distributed

7 Horace Bushnell, discussed at length in Chapter One of this study, was in many ways the father of Christian Liberalism from the 1840s and onward, and his writings shaped liberal theology (particularly Unitarianism) for more than a century. He writes, "your church... should be a city without walls," and where congregants "go into by-places and dark neighborhoods, seeking out Christ's poor and sick; drawing others out of the wrecks of fortune and the more appalling wrecks of vice, by his Christian sympathy" $(264,54)$. Horace Bushnell, Pulpit Talent, Training for the Pulpit Manward, Building Eras in Religion, and Literary Varieties. London: Folkard \& Sons, 1882.

8 Sheldon first began this practice as a young pastor in Waterbury, Vermont, when he decided to print his sermons to aid parishioners who were hard of hearing. Soon he appreciated this new reach and was printing and distributing his sermons at the local post office and village stores (Miller 17-18). 
sermon-stories that told dramatic tales of social uplift and individual improvement — complete with love interests and even cliff-hangers that would bring back the faithful on the following Sunday. The minister saw no false division between creative use of print culture and Christ's work on behalf of the kingdom. If God was the Author of all things, he could certainly work through a well-told story to motivate believers into Christian service.

And there was much work to be done as the nineteenth century drew to a close and a new century dawned. When Sheldon looked out on his frontier parish, he saw crushing need, lack of opportunity, and an community of black citizens who were experiencing hardship as debilitating as slavery. White Christians were largely isolated from the struggle of black Americans, and, just as often, were uninterested in getting involved. But Sheldon reserved his most ardent compassion for the black residents of the nearby Tennessee Town neighborhood, where he believed the need was greatest and, therefore, the calling of Christ was strongest. Sheldon stood at the crossroads of an era of American religious history and American race relations that is easily misunderstood and repeatedly oversimplified; most often, it is not addressed at all. But amid the convergence of turn-of-the-century issues involving race, reform, theology, and literature, there exists a cache of narratives that echo throughout the century to today: the experiences of black Americans who struggled in their first half-century of freedom to find education, opportunity, and acceptance; the efforts of reformers like Sheldon, who used literature to call for and implement tangible improvements in poor, working class, and African-American communities; and liberalized strains of Protestantism that led theologians, ministers and lay people to debate what it meant to follow Christ in regards to service, sacrifice, and brotherhood.

For most historians and American literature scholars, Charles Sheldon's decades of ministry and prolific writing career hold no connection to late-century racial reform and bear no 
resemblance to high-theology debates coming out of the nation's divinity schools. Rather, Sheldon — who was hailed in 1902 for helping construct "the gospel for the modern age"-has quietly faded into the past, despite his overwhelming national celebrity at the turn of the century. ${ }^{9}$ Those who are loosely familiar with Sheldon know him as the author of a best-selling moralistic novel with a subtitle that became an evangelical catchphrase-In His Steps: What Would Jesus Do? Literary critics who reference Sheldon do so as an afterthought or even reluctantly, such as Paul Boyer who, after lamenting that scholars "have not generally examined the book [In His Steps] itself with the care which it deserves," proceeds to impugn the text for its “abysmal literary quality."10 Boyer's 1971 article is routinely cited in examinations of Sheldon's bestseller, but its weak and apologetic argument is a testament to the anemic scholarship on Sheldon, the man and the writer. ${ }^{11}$ In general, scholars seem to regard Sheldon as a kind of "folk theologian," ignoring his years of training at Andover with the nation's best theological minds and flattening his contribution to one of Protestantism's most enduring concepts of the Savior. In short, Sheldon has become not only popular, but a popularizer of social Christianity —a term that implies a certain lack of intellectualism, a status of "mouthpiece" rather than originator of a new and radical gospel. ${ }^{12}$

\footnotetext{
9 Eberman, 201.

10 Paul Boyer, "In His Steps: A Reappraisal." American Quarterly 23.1 (Spring 1971):60-78. 61.

11 While my interest lies in Sheldon's novel The Redemption of Freetown, it is worth noting how scholars have treated his most well-known book in their work. As one of the leading "experts" on Sheldon, Boyer's simultaneous embrace and dismissal of In His Steps is perplexing. Demonstrating a lack of Sheldon's aims in his specific cultural and historical moment, Boyer holds that In His Steps is "concerned only minimally with religion, social injustice or reform, but ... is concerned, almost obsessively, with certain psychological and emotional problems troubling the American middle class at the turn of the nineteenth century" (62). Most remarkably he even asserts that, "The standard interpretation of In His Steps as a radical Christian critique of post-Civil War industrial America, and a visionary call for its transformation, simply does not stand up under scrutiny" (66-67).

12 For scholars who characterize Sheldon as a "popularizer," see Wendy Miller Roberts, "In His Steps in the Context of Regionalist Fiction." Rocky Mountain Review of Language and Literature 61.2 (2007):44-53; Susan Curtis, A Consuming Faith: The Social Gospel and Modern American Culture. Columbia MO: University of Missouri, 2001.; and Robert Glenn Wright, The Social Christian Novel. New York: Greenwood Press, 1989. Miller also refers to Sheldon with this term, but his respect for Sheldon's "untheological" yet theological approach
} 
By divorcing Sheldon from historical nuance and religious history, scholars neglect his revolutionary message and overlook his part in fashioning the Social Gospel movement. My work focuses on reconnecting Sheldon to the larger currents of debate and reform in his era—on which his writing had great influence - rather than evaluating his fiction according to an abstract (and quite honestly ill-defined) standard of literary quality. ${ }^{13}$ As one of the most popular novels in all of American literary history, Sheldon's novel In His Steps initiated new conversations among American Protestants. When it came to everyday actions and social issues, what would Jesus do? How were Christians to act, amid the questions and challenges of the century's end? What was required of them politically, spiritually, communally, and economically, as followers in Christ's steps? These practical theological questions, established in Sheldon's text, extend into and are complicated by his other novels (30 in all), many of which he wrote, like In His Steps, as sermon-stories for his congregation. In these subsequent texts Sheldon particularized his social gospel message, advocating fair treatment of African Americans, Native Americans, Jews, Catholics, criminals, immigrants, and the poor. ${ }^{14}$ As a result, scholars who decry Sheldon for the

comes through clearly in the biography. In short, Miller does not seem to regard Sheldon as merely a mouthpiece for the movement, but instead writes that the peak of Sheldon's career "coincided with the peak of the social gospel movement, and... Sheldon's contribution to the movement was an important one" (137).

13 Critics who dismiss Sheldon's novel, even while mentioning its popularity, seem to have no real standard for what literature of the era should be or what makes Sheldon's work so unsatisfactory. In His Steps is certainly a didactic tale and the characters are thinly-veiled representations of societal "types" for whom the novel is intended - a local newspaper owner, an heiress, a railroad executive, a talented but directionless young woman. Each of the characters is privileged economically or holds a position of influence, and the book draws on sentimental tropes to communicate Sheldon's message (which will be later discussed in this chapter). The characters are emotional, dramatic voice pieces for his religious beliefs, but one could easily indict other popular novels of the second half of the nineteenth century for being guilty of the same "aesthetic" sins of form - novels widely studied and praised for their influence, like Harriet Beecher Stowe's Uncle Tom's Cabin (1852), Elizabeth Stuart Phelps's Gates Ajar (1869), or even Lew Wallace's Ben-Hur: A Tale of the Christ (1880). While it is not my indication to uncritically sing the praises of Sheldon's bestseller, it is unsatisfying to find such widespread and unarticulated scholarly disdain for a novel (and more importantly, a writer) so critical to the development of the social gospel movement and, subsequently, to an entire genre of popular American fiction.

14 McConnell notes that Sheldon's concern for the mistreatment of minorities could be traced back to his early years "among the Indians on the prairie" (10). Sheldon's family had moved from Rhode Island to the Dakota Territory, because his father, a Congregational minister, had health problems. Sheldon later wrote that he regretted "the wrongs inflicted on [native] people for years by brutal Indian agencies and land grabbers" (10). 
"absence" of "Roman Catholics, Jews, Negroes, and immigrants" in his work, simply have not read far enough in his catalog. ${ }^{15}$

More accurately, Sheldon was a revolutionary, with his fictional exhortations demonstrating an egalitarianism rarely seen in his time. Sheldon believed all human beings were equal, regardless of race, gender, class, or nationality, because all were precious in the eyes of Christ. ${ }^{16}$ A socially minded, Christocentric faith meant a genuine concern for "the least of these," and his beliefs about racial inequity were not passive nor did he avoid trudging into the mess of race relations (even while many of his contemporaries-Moody, Billy Sunday, and othersrefused to do so). Instead, Sheldon insisted that equality under God meant African Americans deserved educational opportunity, job training for men and women, domestic skills (including gardening, "neighborhood improvement," home care, hygiene), and equality before the law. ${ }^{17}$ Christians were responsible for ensuring this opportunity and assistance - even to the point of sacrifice - as part of their mandate from God to love their neighbors as themselves. The church, in Sheldon's mind, was not simply a meeting of believers on Sunday: the church was a dynamic

15 This critique proceeds from Allen Shepherd whose analysis of In His Steps is unfortunately representative of so many critical examinations of Sheldon and his novel. Shepherd seems to understand the aims of social Christianity, and he even devotes a paragraph to characterizing Sheldon as part of the larger Social Gospel movement. But because of his limited foray into Sheldon's fiction (mostly consisting of a skim of the novel's plot), he argues that Sheldon never explains, "just how these people knew what Jesus would do." He concludes, "Here is intimated a larger questions unanswered by most Social Gospel fiction: what precisely is the relation of a religion to the society in which it is practiced." As I argue in this chapter, Sheldon does answer this question in future works and, if not viewed anachronistically, his "brand" of Christianity incorporates staid theology of the Protestant tradition and translates it into practical, accessible messages of action. See Allen Shepherd, "The Social Gospel According to Charles Sheldon: In His Steps.” The Markham Review 10 (1980/81):1-4. 2.

16 See Timothy Miller, Following in His Steps: A Biography of Charles M. Sheldon. Knoxville: University of Tennessee, 1987. 156-159.

17 In "A Social Experiment" Charles Sheldon writes about his church's "Village Improvement Society" in the black neighborhood of Tennessee Town, in Topeka. A committee from Sheldon's Central Church instructed residents in "garden culture" and other neighborhood improvement projects, and later prizes were awarded for the changes. Sheldon writes that "scores of Negro families last summer raised enough produce on their little lots surrounding their cabins to supply them with vegetables all fall, and in several instances all winter. It is safe to say that in a neighborhood, which for years has been notorious for poverty and shiftlessness, garden produce worth hundreds of dollars have been raised by families that formerly allowed the soil about their homes to lie idle and grow weeds higher than their cabins" (260). 
community of disciples who were to engage in a variety of "parish social efforts" to help build the Kingdom in this life and the one to come.

Sheldon's work was truly an interracial effort, too, as he traveled to and learned from black ministers in the East who had established socially-minded churches (precursors to the institutional church, as I will show) to better reform their communities and to translate Christian beliefs into tangible action. While Sheldon should be understood as a revolutionary among white Christians and certainly in his rural frontier region, it is also essential to place him within the development of the institutional church, nationally — a movement led by black and white ministers who believed societal change would only come through a reconceived notion of church and its role in society. Once again, this reflects an ecclesiastical shift toward liberal Christianity in some Protestant communities, with crosscurrents of what would grow into black liberation theology and the Social Gospel movement in the next century. Sheldon's church's settlement house in Topeka, then, was literally on the geographic margins of America and also on the "frontier" of Protestant church culture, as it became a model for expanding the "institutional" church to impoverished and underprivileged areas and stood as a testament to what was possible when believers took the church into the world. ${ }^{18}$ Sheldon even organized and regularly participated in inter-race church services and encouraged his white parishioners to worship with black members of their communities. ${ }^{19}$

18 Sheldon endorsed both forms of church outreach, and after visiting institutional churches in cities back East he modeled his own Central Church on that model of outreach (Miller 143). He also believed settlement houses to be especially useful in large cities, a method he illustrates in The Redemption of Freetown. Miller writes that Sheldon even endorsed Ralph Albertson's social gospel commune, the Christian Commonwealth Colony, in Georgia (137). Similarly, Sheldon was likely aware of Reverdy Ransom's remarkable work with institutional churches in Chicago, something I will investigate in more depth later in this chapter.

19 Inter-racial worship services were quite uncommon in most Protestant churches after the war-North, South, or even on the frontier in Kansas. But not only did Sheldon encourage black and white believers to worship together-he took members of his white congregation into black neighborhoods and held church services there. Sheldon's Central Church also had a satellite church in the all-black Tennessee Town neighborhood of Topeka, where resident black ministers rotated with "visiting" white ministers from Central Church and other churches in 
To examine Sheldon's place in American religious and literary history, then, this chapter relocates Sheldon at the center of the deep theological shifts that ushered in the twentieth-century Social Gospel movement, and it connects his practical theology of spiritual and earthly redemption to the problem of racial inequity. To understand what he called "untheological Christianity," I will retrace Sheldon's own steps of spiritual formation to uncover how emerging "new school" liberalism forever shaped Sheldon's approach to Christian community. I illustrate, second, how Sheldon's goal of imitatio Christi permeated his approach to racial reformspecifically in the Tennessee Town neighborhood of Topeka—distinguishing him as one of the most progressive figures in American religious history. Finally, I demonstrate how the two paths converge, as Sheldon's reverence for the written and spoken word led him, time and time again, to take up his pen on behalf of practical Christianity.

I focus my examination on Sheldon's overlooked but dramatic 1898 novella The Redemption of Freetown, which explicitly outlines his vision for race reform and demonstrates his conviction that a Christian social gospel could conquer the mounting forces of racism. To my knowledge, the text has never been examined at length by any scholar, despite the fact that it saw multiple editions and printings, both across the country and abroad. ${ }^{20}$ Sheldon hoped the story would encourage young Christians, especially those of the international Christian Endeavor

the vicinity (Miller 59-60). This is in stark contrast to nationally known revivalists like Dwight Moody, who held segregated services through the early decades of the twentieth century. See also Mark Noll, God and Race in American Politics. Princeton: Princeton University, 2008. 79-80 and Edward J. Blum, "'O God of a Godless Land': Northern African American Challenges to White Christian Nationhood, 1865-1906. Vale of Tears: New Essays on Religion and Reconstruction. Ed. Edward J. Blum and W. Scott Poole. Macon, GA: Mercer University, 2005. 99-101.

20 It is difficult to pinpoint exact publication data on The Redemption of Freetown, but WorldCat shows multiple editions/printings in the U.S. and abroad, the first of which was through the United Society of Christian Endeavor in Boston and Chicago in 1898. The novel was reprinted in 1899 by Chicago Advance Publishing Company and published abroad by the Poole Print Company of Toronto in 1898 and 1899, by Frederick F. Warne \& Company in London in 1899, and by the Sunday School Union in London (multiple editions) in 1899. The book was authored just two years after Sheldon's In His Steps garnered best-seller status, and by then Sheldon had gained somewhat of a celebrity status among Congregational and progressive circles. 
Societies, to redeem their fractured communities and fashion a better future free of prejudice. But ultimately, I argue that Sheldon uses Redemption to call all believers to a turn-of-the-century Great Commission - to work for redemption that is both earthly and spiritual, to combat what he considered the evils of "race prejudice," and to convert unbelievers "by the personal touch of soul on soul." 21 The novel alludes to multiple scripture passages on discipleship and takes as its central text Isaiah 6, in which the voice of the Lord asks, "Whom shall I send? And who will go for us?" to which the prophet responds, "Here am I. Send me!"22 By employing this direct and dramatic encounter with the language of Commission, Sheldon sculpted a homiletic built on the sacred principle of sacrifice to usher in a new era for black and white Christians alike.

\section{Sheldon's Theology: Finding A “Christianity Appropriate to Each Age”}

When the Reverend George Harris succeeded Edward Park as Abbot Professor of

Christian Theology at Andover Theological Seminary in 1883, sitting in the audience for

Harris's inaugural address was a young Charles Sheldon, just beginning his seminary studies.

The transition from Park to Harris signaled, in effect, a changing of the guard for the

Congregational school and a tenuous embrace of New Theology. The "Andover Controversy," as

it is so often called, subsequently erupted into years of bitter disagreement among faculty, the establishment of The Andover Review by liberal professors, and seminary-wide debates about

21 Charles M. Sheldon, “Article 6: No Title.” The Independent 48.24 (14 May 1897):11; Sheldon, "Practical Sociological Studies," 369.

22 Taken from Isaiah 6.8, KJV. While the Reverend Clarence E. Eberman notes in a 1902 article on Sheldon that the minister "read the Word from the Twentieth Century New Testament," this passage from the Old Testament was most likely one that Sheldon would have read in the King James Version-the standard for that era. All biblical texts quoted here will be from the KJV, including New Testament verses, as the TCNT was not published until 1901. Interesting, as part of his article, Rev. Eberman provides an aside on the TCNT's merit, offering, "Whatever critics may say concerning the Twentieth Century New Testament, its literary value or otherwise, people will listen when it is read to them, for the modern setting illuminates the old truths in a most remarkable manner." See, Clarence E. Eberman, “A Sunday with Rev. Charles M. Sheldon.” Congregationalist and Christian World 87.6 (8 Feb. 1902):201. 
higher criticism, biblical fallibility, second probation, work of the Spirit, scientific rationalism, and evolutionary theory. ${ }^{23}$ The disagreements between "old" and "new" theology-between the orthodox Calvinism of Andover's founding and emerging, liberal theology-divided the entire Congregational community. Sheldon witnessed the tumult first-hand. ${ }^{24}$ The tensions culminated in 1886, when Andover's Board of Visitors brought accusations of heresy against the faculty editors of The Andover Review for what the Board believed were unorthodox teachings concerning the fallibility of scripture and second probation. In response, Andover's graduating seniors published a letter in the Christian Union, writing, "We emphatically and indignantly deny that the charges in question are true. [...] Our notebooks containing their lectures... show that Andover teaches today as faithfully as ever those doctrines which are fundamental in the evangelical faith." 25 All twelve of the 1886 class signed their names to the letter, including Charles M. Sheldon.

But what was Sheldon defending, just fresh from completing his seminary studies and a decade before publishing the best seller that gained him celebrity? How had his experiences with New Theology at Andover shaped him and the practical Christianity he would come to espouse?

To answer these questions, it is useful to look at the text of George Harris's inaugural address to the Andover community, which glimpses Andover's theological progressivism in the

23 The term "second probation" (also called "future probation") refers to the belief that those who were never exposed to the gospel will receive a "second chance" at salvation after they die. In the context of the Andover debates, Gary Dorrien explains: "They [the liberal professors at Andover] pressed hard for a New Theology that made peace with modern science, especially evolutionary theory, and for continued progress in theology and society. They called for a Christian appropriation of Darwinian theory that opposed orthodoxism and scientific rationalism alike, appealed for a morally acceptable understanding of Christ's atonement, and questioned the logic of substitutionary atonement. Most provocatively, they defended the doctrine of a future probation for those who did not hear the gospel in this life" (292). See Gary Dorrien, The Making of American Liberal Theology: Imagining Progressive Religion 1805-1900. Louisville: Westminster John Knox, 2001.

24 For a more extensive look at the Andover Controversy, see Cara L. Burnidge, "Charles M. Sheldon and the Heart of the Social Gospel Movement" (2009). Electronic Theses, Treatises and Dissertations. Paper 2731. Perhaps more than any other recent scholar, Burnidge seeks to return Sheldon to the context of the Social Gospel and, in doing so, investigates how his religious experiences shaped his message.

25 “Andover Theology." Christian Union 34.18 (October 1886):28. 
years of Sheldon's tenure. The address, boldly titled "The Rational and Spiritual Verification of Christian Doctrine," was a respectful yet bright manifesto, in which Harris denounced the church's intransigence in the face of modernism and outlined the exciting possibilities inherent in New Theology. Above all, Harris argued Protestantism must remain relevant and that "each generation must do its own thinking. Christianity, which is always the same, must be thought out into the forms appropriate for each age. ${ }^{.26}$ It was time for Congregationalists to seize the opportunities inherent in subjectivism and scientific rationalism, he insisted, and stop giving old answers to new, late nineteenth-century questions. ${ }^{27}$ Subjectivity, Harris noted, was not something to be feared, but it tailored the gospel to "each age... in accordance with existing knowledge and conscious need. ${ }^{.28}$ Truth was made vivid through this subjective experience, and therefore "experience is the grounds of certainty," not "merely historical or theoretical forms" to which the church clung. ${ }^{29}$ As if these proclamations were not dramatic enough, Harris went on to contend that, while the scriptures expressed the truth about Christ and his salvation, biblical interpretation could not "be separated from our intelligence illuminated by the Spirit of truth."30 In regard to the debate about scriptural infallibility, Christians must refuse to separate "sacred" truth from "secular" knowledge, experience, and understanding; such false separations and rejection of rationalism had, historically, resulted in the "partial failure of the church to translate truth into life." ${ }^{31}$

To overcome contemporary challenges to Christianity, then, Harris encouraged the young

26 George Harris, The Rational and Spiritual Verification of Christian Doctrine. Andover: Warren F. Draper, 1883. 36.

27 For more on the Andover school's twinned approach to theology and rhetorical education, see Michael-John DePalma, "Rhetorical Education for the Nineteenth Century Pulpit: Austin Phelps and the Influence of Christian Transcendentalism at Andover Theological Seminary." Rhetoric Review 31.1 (2012):1-20.

28 Harris, 8.

29 Ibid., $10 \& 9$.

30 Ibid., 27.

31 Ibid., 28. 
seminarians to turn their attention back to the Author and Perfector of their faith, declaring, "Now the person of Jesus Christ is the center of theology." ${ }^{32}$ In the past, Christians had been motivated by "Divine Sovereignty" or "Justification by faith," he said, but the dawning of a new century—with its gnawing questions and upheaval across civilizations—yearned for the Mediator between God and man, heaven and earth. It is significant, too, that Harris refers multiple times to "the person of Jesus Christ," emphasizing both the savior's humanity and the theological principle of kenosis, or the concept that Jesus "emptied Himself" of his divinity in order to submit to the Father's will and experience life on earth in human form. Christ then became the willing sacrifice, as a man capable of understanding and even empathizing with humanity. For Harris, Sheldon, and so many others of their age, Jesus would be the "center of theology" for individual Christians by being the perfect Example of self-sacrifice, compassion, and an earthly ministry that changed lives. Corporately, Christ-as-Example also provided a model for the church body, unifying individual believers, through brotherhood, in the community of God. ${ }^{33}$ Redemption no longer meant the "rescue of an individual here and there," Harris said, but rather the "solidarity of the kingdom... in the establishment of a purified society.",34

In short, Harris's proclamation signaled that a new Christological paradigm was energizing American Christianity, broadly, and the Congregational community, specifically. By freeing the gospel message to blend with modernist theories of truth and subjectivity, by elevating Jesus's humanity, and by portraying redemption as communal, the church would show itself

32 Ibid., 32.

33 While Harris refers several times to the "person of Christ" (7 \& 22), "God-man" (32), and the "historical Christ" ( $7 \&$ 22), this merely seems an emphasis of Jesus's humanity, in a way that is appropriate to the times, not a dismissal of his divinity. Similarly, Harris discusses the doctrine of the trinity in the context of its relevance to the Reformation era, but in doing so does not invalidate or contradict a belief in the trinity. Ultimately, Harris seems loyal to a "hypnostatic" view of Jesus - maintaining that Jesus possessed a full undiminished human nature and a full undiminished divine nature, which were not combined or confused into some new nature, but existed distinct and forever in the one person Jesus Christ.

34 Harris, 33. 
"appropriate" to the age. Today's readers may easily miss the provocative aspects of Harris's theological assertions, and certainly Andover was not the most radical of the New Theology schools; but truly, as Gary Dorrien notes, "the liberalization of Andover Seminary was an historical watershed" in American theological teaching and in Congregationalism. ${ }^{35}$ In ways not yet appreciated by scholars, these theological positions came to dominate Sheldon's own Christocentric vision — expressed through his writings and sermons and in his practical work in the community on behalf of the gospel. ${ }^{36}$ This is not to say one can simply transfer Harris's views to Sheldon; rather, by locating Sheldon at Andover, during the time of a momentous shift in Protestant thinking, we can finally appreciate the molding influences of New Theology on Sheldon's social gospel.

In many ways Sheldon's liberalism superseded the New Theology he had encountered at Andover. ${ }^{37}$ As he went about his ministry, first in Waterbury, Vermont, then in Topeka, Sheldon

35 Dorrien, 292. Dorrien also notes that, despite its publicity, the "Andover Controversy" was still quite mild compared with turn-of-the-century upheavals experienced at Union Theological Seminary, Boston University, and the University of Chicago.

36 While Gregory S. Jackson provides a theologically-grounded examination of homiletic novels, his characterization of Sheldon's time at Andover never mentions the late century "Controversy." This oversight is curious, as Jackson notes the school's "Calvinist pedagogical strategies" and says Andover was "still a center of conservative theology and homiletic technique" when Sheldon attended.

37 Once again, critics who only skim the surface of Sheldon's work fail to understand his liberal theological persuasions. For example, Allen Shepherd incorrectly states, "Among Social Gospel theologians, Sheldon held a more conservative perspective, more closely allied, for example, to that of Washington Gladden than to that of Walter Rauschenbusch" (1). Shepherd never defines what he means by conservative or liberal, nor does he account for Sheldon's more progressive treatment of race, compared to Rauschenbusch's only casual mentioning of prejudice. But that may be because Shepherd's examination fails to read beyond In His Steps. The same is the case with William C. Graham's otherwise useful discussion of In His Steps, when he writes that Sheldon is "more closely aligned with the more conservative wing of the [Social Gospel] movement," because he believes regeneration is a "return to the Gospel" (71). Liberally minded Social Gospel leaders, according to Graham, believed that the "Kingdom [of God]" was the "force which rejuvenates society" (71). This may seem a minor point, but in other areas of Sheldon's writing, he clearly endorses a belief in Kingdom building. In his 1898 essay "The Law of Christian Discipleship," he writes that, when Christians truly follow Jesus and act sacrificially in society "the kingdom of God is established." In an 1899 interview, Sheldon remarks on "advance[ing] the Kingdom" of Jesus (qtd. in Devins 69). And over and over again in The Redemption of Freetown Sheldon exhorts Christian readers to consider whether they were building the "best society" on earth (and who they may exclude). See Jackson; Shepherd; William C. Graham, Half Finished Heaven: The Social Gospel in American Literature. Lanham, Maryland: University Press of America, 1995.; and John Banoroft Devins, "With the Author of 'In His Steps." New York Observer and Chronicle. 77.29 (20 July 1899):69. 
retained the principles Harris proclaimed, but stripped them of denominational labels in favor of Christian unity. Other liberal theologians began to do the same in the late decades of the nineteenth century, believing that "America would never be Christianized as long as the churches perpetuated" a competitiveness among denominations and doctrines. ${ }^{38}$ Because Sheldon held ultimate reverence for Jesus's teaching, early in his Topeka pastorate he argued, "There is no good reason today why the Congregational, Presbyterian, Methodist, Baptist, Lutheran, Episcopal, and Christian churches should not be one church in name and reality. ${ }^{39}$ He held that the basis of this unity would be "the creed of Christ. And what was that? Supreme love for God and supreme love for man. ${ }^{, 40}$ This sentiment, of course, echoes Jesus's proclamation in the New Testament that the two greatest commandments are to love God and love one's neighbor. For Sheldon, these commandments were the goal and thesis of every Christian life, and Christians could do more together than they could bickering over each "jot and tittle" of scripture. ${ }^{41}$

In practice, Sheldon demonstrated his belief in ecumenicalism at every turn: soon after taking over Central Congregational Church in Topeka, Sheldon dropped the denominational moniker and simply referred to his institution as "Central Church." In 1899 Sheldon devoted a full-length sermon-story to ecumenicalism, with the publication of his novel The Miracle at Markham: How Twelve Churches Became One-a fictional parable of an Ohio town who unified its churches under a common cause of service to society. ${ }^{42} \mathrm{He}$ also worked closely with ministers

38 Gary Dorrien, The Making of American Liberal Theology: Imagining Progressive Religion, 1805-1900.

Louisville: Westminster John Knox, 2001. 323.

39 Sheldon qtd. in Miller 180.

40 Sheldon qtd. in Miller 180 (emphasis in the original).

41 The phrase "jot... and tittle" comes from Matthew 5.17-18, where Jesus declares the enduring nature of God's law, stating, "Think not that I am come to destroy the law, or the prophets: I am not come to destroy, but to fulfil. For verily I say unto you, Till heaven and earth pass, one jot or one tittle shall in no wise pass from the law, till all be fulfilled" (KJV).

42 The sermon story told of Markham, Ohio - a small town with nineteen churches. Each church suffers from financial woes and the congregations disagree and are divided throughout the town. After a fire destroys one of the church buildings, two congregations begin worshipping together and, soon, ecumenicalism spreads and many 
of all denominations in his vicinity, combining church functions, inviting guest preachers, and working on community projects with other churches. Sheldon even regularly shared pastoral duties with a Presbyterian pastor at an adjoining church, and stated, "the sight of two brethren of differing denominations, going together throughout their parishes... is a sight which will do more in a short time to break down denominational lines, and build up a true federation of Christ's disciples, than possibly any other thing. ${ }^{, 43}$ When it came to the gospel, Sheldon believed in operating with unity and singularity of purpose toward practical ends. It was of no importance, to him, whether his methods placed him in the category of "orthodox," or "liberal," or even "heretic"; rather, Sheldon sought to erase these categories altogether, under the motivating banner of Christ's redemption.

At the ultimate center of Sheldon's life, writing, and teaching was Christ. For his entire ministry, Sheldon's endeavors reflected Harris's prescient declaration, "Now the person of Jesus Christ is the center of theology." The church had its faults, Sheldon acknowledged, but Jesus was the one pure hope for all of humanity. Discussing his interaction with parishioners, Sheldon wrote in an 1890 editorial for the Andover Review, "Many a man sneered at the church, and found fault with the preacher, but not one had a word to say against the Carpenter of Nazareth."44 This led Sheldon to an even "firmer belief in the power of an applied Christianity to reach men everywhere." 45 Christ's redemptive power would change the believer into a "new man," and this "regeneration" could transform whole communities to address issues of depravity, poverty, or

churches unite to make real progress for the town. It is difficult to ascertain whether Sheldon based the novel on actual events, but in my searches I found no such direct link. See: Charles M. Sheldon, The Miracle of Markham: How Twelve Churches Became One. Chicago: The Church Press, 1899.

43 Miller, 182. In 1901 Sheldon spoke in a lecture at Cobb Divinity School in Lewiston, Maine, about his work with his "brother" at the neighboring Presbyterian church. 44 Sheldon, "Practical Sociological Studies." 369. 45 Ibid. 
racism. ${ }^{46}{ }^{47}$ For Sheldon, Christ's love and example was the answer to any question, no matter how complex. In this way, it is fitting for Sheldon to be known according to his bestseller, In His Steps, which asked, as Sheldon so often did in his own ministry: "What would Jesus do?” Of course, to some in Sheldon's time (and today), this message appeared too underdeveloped, too glib. But Sheldon insisted placing Jesus "on the throne of a man's life" was not an easy task and would not result in the "nominal Christianity of the world"; it meant the "imitation of Jesus" even to the point of "self-denial" or death. In an essay for Zion's Herald in 1898, Sheldon insisted that being a Christian meant a willingness to "surrender anything to the Master's service" - a "test of discipleship" that was not without challenges, and certainly not without cost. $^{48}$ Times had changed, Sheldon acknowledged, but the message of Jesus had not.

Often scholars mistake Sheldon's simple message for a simplistic one, believing him incapable of theological complexity. But it is an error to think Sheldon's decades of ministry were truly "untheological" - he who grew up with a Congregational minister as his father, who attended Andover during the pinnacle of its transition from Calvinism to liberalism, who spoke extensively on returning to Christ's Greatest Commandments, who hailed the necessity of ecumenicalism, who embraced evolution and higher criticism, and who preached extensively on the brotherhood of man. Rather, when Sheldon praised "untheological Christianity" in a Christian Century article, he was really distanced himself from the doctrinal (and, as he saw them, inconsequential) squabbles that pervaded Protestantism at the time. Denominational particularity had convoluted Christ's simple, powerful message, he said, and evolved into "a system of forms and ceremonies about the thing called Christianity that are as far removed from

46 Sheldon, "The Law of Christian Discipleship." 265.

47 For an insightful discussion of Sheldon's theology of the Incarnation, as it relates to In His Steps, see Wayne Elzey, “'What Would Jesus Do?' In His Steps and The Moral Codes of the Middle Class." Soundings 58.4 (Winter 1975): 463-489.

48 Charles M. Sheldon, “The Law of Christian Discipleship.” Zion's Herald 76.9 (2 March 1898):265. 
the teaching of Jesus as He was removed from the scribes and Pharisees of His own time."49 That is not to say that Sheldon ignored contemporary debates or kept his religious beliefs separate from his politics; rather, he chose to address issues of tangible, everyday import, not elusive doctrinal entanglements. When Sheldon did speak, his belief in Christian brotherhood, equality, and purity motivated his endorsements: he crusaded passionately against liquor (it didn't matter that Jesus drank wine; times had changed, Sheldon said, with the invention of the saloon), he championed women's rights (far beyond the right to vote), he was pro-union, he deplored the injustice suffered by Indians, and he vehemently condemned the Ku Klux Klan when it appeared in Kansas. ${ }^{50}$

Ultimately, Sheldon's theology was radical in its simplicity, liberal in its fidelity to the ancient principle of imitatio Christi. Through this theology, Sheldon launched a social gospel that would reach millions, all while working locally to "[plow] new ground in pastoral counseling, liturgical reform, and the role of theology in church life." ${ }^{, 51}$ Most importantly, Sheldon's insistence on unity and his practical Christocentric theology led him to the doorstep of society's most forgotten members: the black citizens of Tennessee Town who would teach him Christ's love in both word and deed.

\section{Sheldon's Social Vision: "Christianizing the Negros" by "Christianizing the Anglo-Saxons"}

When Sheldon embarked on his pastorate at Central Church in 1889, Topeka was more than thirty percent black - a higher percentage than New Orleans. ${ }^{52}$ Racist sentiments were

49 Sheldon qtd. in Miller 183.

50 Miller, 156-157. Sheldon did not fear a conflict between his modern times and his faith. At one point, later in his career, he remarked, "Evolution? I believe in it. It dignifies the work of God. I believe in radio and the miracles, in airplanes and the divinity of Christ. I believe in all those wonderful things" (193).

51 Miller, 179.

52 Sheldon came to Topeka in January of 1889 and so the most recent census data, quoted here, comes from the 
escalating, and, according to historian Thomas C. Cox, local officials and many white residents blamed the city's shifting racial composite for its social ills. Citywide, there was a burgeoning if stratified class of African Americans, with the "black press claim[ing] that Negroes were in accord with the 'interests of the average citizen... in schools and good streets' and... in the reform concerns common to the period." ${ }^{, 53}$ But, Cox notes, "As in most areas of Negro life, their efforts at reform emerged under conditions of racial discrimination." ${ }^{54}$ Speaking of the 1890s, Cox writes that, "black-white relations eroded" further, as resentment toward the influx of "Exodusters" led to crushing prejudice, restricted public funds for relief efforts, rising crimes rates, discriminatory employment practices, and increasing alcoholism and violence. Some "Negro enclaves," as Cox refers to them, did include prosperous black citizens-educated, middle class persons of color who were well established in Topeka, owned businesses, and helped organize a myriad of black organizations and committees in the city. But the Tennessee Town "enclave," specifically, was comprised mainly of the destitute, uneducated "Exodusters," or formers slaves, who had fled the Mississippi Valley after Reconstruction. By all measures, living conditions in Tennessee Town were "substandard." Cox writes that unemployment had "created serious economic dislocations. Juvenile crime was rampant, as was vice, and there was a lively traffic in liquor." ${ }^{, 55}$ At the edge of Tennessee Town's unofficial border stood Central Church, with an ambitious new minister who boldly declared that there was, in fact, no "Negro"

federal census in 1880 (Miller 47). As Miller writes, blacks emigrated to cheaper lands in the West after the Compromise of 1877 ended Reconstruction, and Kansas "was as logical a place to stop as any... widely known as a bastion of antislavery sentiment" (46). By 1880, "some forty thousand Exodusters had passed through Topeka. About three thousand of them stayed," despite the protestations of many white Topeka residents (Miller 47). The next federal census was conducted in 1890, but according to the Kansas State Historical Society, that data was lost in a Washington D.C. fire in 1921. See "1890 Kansas Federal Census," Kansas State Historical Society. Topeka, KS. 2014.

53 Thomas C. Cox, Blacks in Topeka, 1865-1915. Baton Rouge: Louisiana State University, 1982. 104. Cox's study of Topeka's black leaders, organizations, and class diversity is a rare find and reflects the diversity of experiences of the African American community in the decades following the Civil War.

54 Ibid.

55 Ibid, 145. 
problem, but rather a "human problem" borne of and sustained by radical prejudice.

In a service to christen Central Church's new downtown building — one block from the Tennessee Town slum — newly installed minister Charles Sheldon proclaimed that the church would preach "a Christ for the common people," emphasizing Jesus at the center and insisting on unity in all parish endeavors. Sheldon spoke warmly of a Savior who "belongs to the rich and poor, the ignorant and learned, the old and young, the good and bad. A Christ who knows no sect or age... but a Christ who bids us all recognize the Brotherhood of the race, who bids us throw open this room to all." 56 This would be Central Church's creed: a Christ for all, a commitment to brotherhood, a church without borders. As Sheldon biographer Timothy Miller writes, Sheldon preached a "Jesus so human that he could have been sitting in the next pew, accessible to the day laborer and the aristocrat alike." ${ }^{57}$ And Central Church was uniquely situated to reach a varied swath of Topeka's citizens, as its new stone edifice was located in the heart of the city, adjacent both to Washburn College and Tennessee Town. So when Sheldon declared that the congregation must "throw open this room to all," congregants had a good idea of who would come in; the prospect was likely daunting.

But to Sheldon, every challenge to Christ's kingdom was an opportunity, and he believed fervor was gaining, nationally, for this new social Christianity. He wrote of feeling a "growing shame" that the church was regarded as a place to "be avoided by those who need it most" and, to bridge the gap, he urged believers to go out into the community and "acquaint [themselves] with the life of the world" in order to better minister to the needs of humanity. ${ }^{58}$ Sheldon practiced what he preached, conducting several social "experiments" to get to know Topekans-

56 Miller, 23.

57 Miller, 34-35.

58 Sheldon, "Practical Sociological Studies," 369. 
to live and walk among them just as Jesus interacted with the masses in his earthly ministry. The most extensive of Sheldon's studies lasted nearly three months and exposed Sheldon to a crosssection of citizens: "the horse car and electric car men, the Washburn College students, the negroes, the railroad men, the lawyers, the doctors, the business men, and the newspaper men." 59 He pledged to spend a whole week with each of the eight groups, "living as nearly as [he] could to the life they lived." 60 And as he would so often do during his ministry, Sheldon took up his pen to share his experiences, publishing a reflective, yet rousing article in The Andover Review in $1890 .{ }^{61}$ Sheldon wrote that the experience made him "less inclined to judge men harshly or hastily," and that it forced him to "constantly put [himself] in the other man's place... to quicken [his] sensitiveness to the man's actual need." He argued for a Christian community not only aware of its surroundings and problems, but intimately acquainted with its neighbors. Concluding his essay he urged: "To know men at a distance is not to love them as Christ did, for the multitudes thronged Him. [...] To know mankind is not enough for the preacher. He must know men. [...] The world will be converted by personal touch of soul on soul.",62

On a personal level, Sheldon's ecclesiastical vision had also been forever changed, largely due to his time getting to know the African American residents of Topeka. No other group in the study impacted him as deeply. His week-long stay in the black community stretched to three, as he visited their homes, ate dinner with families, helped them find work, inspected their schools, and interviewed both impoverished families and "the most intelligent and

59 Ibid.

60 Ibid.

61 The Andover Review was a religious and theological journal published from 1884-1893 and branded itself as a voice for "thoroughly progressive orthodoxy." Most contributors were faculty at Andover Theological Seminary, but former graduates also published in the periodical. See Andover Review. Vol. 18. Boston: Houghton, Mifflin \& Co., 1892. 649-650.

62 Sheldon, "Practical Sociological Studies," 369 
prominent public negro men in the city." ${ }^{\text {,63 }}$ Most importantly, Sheldon glimpsed the profound racial divide in Topeka and, in Tennessee Town, the lack of meaningful assistance from white churches. ${ }^{64}$ The (white) press had attributed Tennessee Town's deplorable conditions to the "incompetence" of its residents, being former slaves and descendants of slaves. Sheldon boldly countered these claims, being the first white resident of Topeka to publicly identify racism as the main factor keeping Tennessee Town blacks in menial jobs (or unemployed), with little access to medicine, education, or other basic services. ${ }^{65}$ Insisting that, "sociology is not alone a study of books and principles," but "is a study of hearts and lives," Sheldon embarked on a second, more extensive visit to the all-black neighborhood a few months later to gain more insight into the racial divide. This time he stayed two weeks. He accompanied black men to various places of business (restaurants, shops) to see how they were received (generally well), and he went with them as they inquired about jobs. Most striking, however, was a visit to the Topeka YMCA, where Sheldon's black companion was refused membership and told to "have his own association and so avoid the racial difficulty." ${ }^{66}$ Sheldon described the experience in an 1896 column in The Kingdom, lamenting that, "the Young Men's Christian Association proved less Christian than the restaurant." In the end, Sheldon concluded that reforming the black communities meant first reforming the attitudes of white Christians. He wrote, "I do not have much hope of Christianizing the negro until we have Christianized the Anglo-Saxon. It is a

\footnotetext{
63 Ibid.

64 Miller writes that Sheldon did witness some "Congregational and other Protestant missionary activity" in Tennessee Town, but these "small missionary outposts" were "feeble, unable to combat the area's towering social problems" (49). There were also four black churches in Tennessee Town, that Sheldon said were "controlled by negro preachers, and exercising considerable influence, but not very much that could be called Christian influence" (Sheldon qtd. in Miller 49).

65 Miller, 48. Miller goes on to state that these impoverished conditions eventually led, in the 1890s to a "fair amount of illegal activity." There were "frequent police patrols [that] tried to contain rampant juvenile crime and gambling, and even such police duty was dangerous" (48).

66 Sheldon, “A Local Negro Problem,” 828.
} 
present question with me now, sometimes, which race needs it more.",67

In the coming years Sheldon published and preached vociferously on the issue of social and ecumenical Christianity, with the goal of properly "Christianizing the Anglo-Saxons" and spurring practical action on behalf of their black neighbors. Sheldon's editorials - each one an exhortation for Christian involvement in social issues - appeared in an array of leading journals: The Kingdom, Christian Endeavor World, The Independent, Atlantic Monthly, Advance, The Andover Review, Outlook, The Congregationalist, New York Observer and Chronicle, and Zion's Herald, to name only a few. But the writing most important to Sheldon was his sermon-stories. On Sunday mornings Sheldon's sermons were fairly traditional in style, but early in his ministry at Central Church he dedicated evening services to reading moral tales that he, himself, had composed - narratives he called "sermon-stories." Each week, starting in 1891, he read a chapter of a book-length story on Sunday evening, usually ending with a cliffhanger that would bring his audiences back. Within three weeks of his first story's debut—titled "Richard Bruce, or The Life That Now Is"- the church was packed on Sunday evenings, with people coming from nearby churches and communities to hear Sheldon's tales. Miller writes that, "Interest never flagged; the church remained packed throughout the thirty years" Sheldon read installments of his booklength stories. ${ }^{68}$ Indeed, as the nineteenth century came to a close, the "whole world," according to Harriet Beecher Stowe, was "running mad for stories," and many popular presses would print sermons (especially those that included appealing anecdotes or sentimental tales). ${ }^{69}$ Sheldon's new homiletic approach, then, was also part of a larger movement of turn-of-the-century

67 Charles M. Sheldon, “A Local Negro Problem.” Kingdom 8.52 (10 April 1896):828.

68 Miller, 67. Miller also provides interesting details of Sheldon's carefully planned reading schedule: "The normal pattern was to begin a story in September and read it in twelve installments, ending it just before the Washburn College students were due to leave for the holidays" (67).

69 See David S. Reynolds, "From Doctrine to Narrative: The Rise of Pulpit Storytelling in America." American Quarterly 32.5 (Winter 1980): 479-498. 479 
ministers who employed the power of stories to reach a wider audience. Henry Ward Beecher, Sam Jones, D.L. Moody, and many others embraced the secular press for sacred aims. ${ }^{70}$

One of Sheldon's sermon-stories, his seventh, eclipsed all the rest in popularity; he drafted the sentimental tale in response to the great need he witnessed in his community, and he hoped its narrative power would spark "a revival of the Christianity of Christ."," "In His Steps: What Would Jesus Do?” told of a Reverend Henry Maxwell who, after an encounter with a destitute man, challenges the members of his church to live for one year, acting only as Jesus would. Sheldon composed the tale in 1896, then published it in 1897, making Sheldon's name "almost a household word" and unifying the social gospel into a movement. ${ }^{72}$ Locally, the series reflected a growing fervor for social outreach among Central Church congregants, as fundraising and plans for revitalizing the Tennessee Town neighborhood had already begun in earnest. In His Steps extended Sheldon's vision and nationalized efforts for each Christian to ask, in regard to their community, "What would Jesus do?” And while much scholarship disparages Sheldon's writing, Miller credits the minister's "narrative technique" for this success, commending "his ability to leave stories hanging at the ends of chapters, hinting of future developments; his consistent inclusion of a happy love story in each tale; his clear social commitment, hinting at the social gospel radicalism he could never bring himself to advocate in the nonfiction world; and his ability to communicate simply and clearly."73

While many other ministers used sermon stories - anecdotes told to make tangible various complex theological "truths"—Sheldon's messages had a communal and earthly focus

70 Reynolds, 497.

71 Charles M. Sheldon, In His Steps: What Would Jesus Do? 1897. Uhrichsville, OH: Barbour, 2005. 249. This quote comes from the closing sermon preached by the fictional Rev. Henry Maxwell, but certainly reflects the sentiments of Sheldon, himself (just as the character of Maxwell is a stand-in for Sheldon throughout the story).

72 “Rev. Charles M. Sheldon.” James L. King, Ed. History is of Shawnee County, Kansas, and Representative Citizens. Chicago: Richmond \& Arnold, 1905.

73 Miller, 67. 
even more than an individual, heavenly focus. As a scholar of progressive theology, the Kansas minister scaffolded his sermon stories around an interpretation of the New Testament that he deemed Christian Socialism, an iteration of practical Christianity he believed would revolutionize American society and transform communities like Tennessee Town. His message was aimed at pointing souls to Christ, while also tangibly improving the neighborhood, the residences, the schools, and the general experience of those who lived right beyond the church property. It was in an 1895 newspaper article that Sheldon endorsed Christian Socialism by name - a bold decision for someone living in a conservative state and town. But if the terminology was likely to cause a stir, his definition was not; he wrote, "Christian Socialism is no more, no less than the answer to the Lord's Prayer in an attempt to make the kingdom of God a reality in the every day life of the world." ${ }^{74}$ That fall, he would go on to author In His Steps, a fictional rendering of this new paradigm. In many ways Sheldon's ideology echoed emerging strains of liberal theology, such as the sentiments of his friend Lyman Abbott, who in 1890 provocatively suggested: "Jesus Christ is sometimes called the first Socialist. If every man who desires the social improvement of his fellows is a Socialist, Jesus Christ certainly should receive from a grateful humanity that honorable designation." "75 Sheldon likely agreed with Abbott's stance, but always pressed beyond the theoretical or philosophical to insist on practical work for the kingdom. "Most of us do not know enough to help out the solution of social questions by writing or debating along lines of intellectual economies," Sheldon also wrote in 1890. "But the preacher may live, and a church may live, a socialism that may prove a practical demonstration

74 Qtd. in Miller 107.

75 Lyman Abbott, "What Is Christianity?" The Arena 13 (Dec. 1890):36. After college, Sheldon's first full-time job offer came from Abbott, who was then editor of the socially-minded journal Outlook. Abbott had been acquainted with Sheldon's prolific contributions to Youth's Companion and admired his stance on social issues (Miller 15-16; Hopkins 142). Sheldon declined Abbott's offer, however, choosing instead to enter the ministry, but the two remained in correspondence and, in the last years of his life Sheldon spoke fondly of his "old friend Lyman Abbott" (Miller 219). 
of its possibility."

Sheldon composed In His Steps as a modern-day allegory of imitatio Christi, hoping to demonstrate exactly how a church could live out a socially minded Christianity. Sentimental and ambitious, the tale of Reverend Maxwell and his church did, in fact, motivate Christians in the United States and beyond to examine the fruits of their faith and consider how belief should be lived out in action. Space does not permit me to address the voluminous scholarship on In His Steps - a novel that some sources estimate to have had a readership equivalent to Stowe's Uncle Tom's Cabin. ${ }^{77}$ Nor could one likely improve upon the research conducted by Timothy Miller, John W. Ripley, Gregory S. Jackson, and John P. Ferré. ${ }^{78}$ But it is worth noting the widespread popularity and foundational role of In His Steps, both for Sheldon's personal vision and for the national Social Gospel movement. Publication of the novel corresponded with a rise in social Christian literature from Elizabeth Stuart Phelps's The Silent Partner (1871) and Washington Gladden's The Christian League of Connecticut (1883), to Albion Tourgée's Murvale Eastman, Christian Socialist (1890), William T. Stead's If Christ Came to Chicago (1894), and Charles Gordon's Black Rock (1898). ${ }^{79}$ But no other social gospel text was as successful at reaching a wide and diverse audience as In His Steps. First published in serial form in 1896 by The Advance (a Congregationalist weekly magazine), a faulty copyright made the text public domain and,

76 Sheldon, "Practical Sociological Studies," 369.

77 See Eric F. Goldman, "Books that Changed America," Saturday Review 36.27 (4 July 1953): 9, 38. Also see Wright, 108-109; Graham, 57

78 See John W. Ripley, “The Strange Story of Charles M. Sheldon's In His Steps.” The Kansas Historical Quarterly 34.3 (Autumn 1968):241-265.; Gregory S. Jackson, “'What Would Jesus Do?': Practical Christianity, Social Gospel Realism, and the Homiletic Novel.” PMLA 121.3 (2006):641-661.; John P. Ferré, A Social Gospel for Millions: The Religious Bestsellers of Charles Sheldon, Charles Gordon, and Harold Bell Wright. Bowling Green: Bowling Green State University, 1988.

79 After Stead's and Sheldon's novels, there was a firestorm of similar publications - more provocatively titled, but not nearly as successful: Milford W. Howard's If Christ Came to Congress (1894), Isaac G. Reed Jr.'s From Heaven to New York (1894), Edward Everett Hale's If Jesus Came to Boston (1895), Olla P. Toph's Lazarus (1895), and Cortland Myers's Would Christ Belong to a Labor Union? (1900). For more titles, see Ferré, Wright, and Miller 69-71. 
within a year, at least sixteen publishers had printed editions of the novel. The book was even more popular in England, and was eventually translated into more than 15 languages, with tens of millions of readers. ${ }^{80}$

Most significantly for this study, In His Steps was Sheldon's main conduit for "Christianizing the Anglo-Saxons" - of returning white Christians to the central tenets of belief, in order to transform how they lived out their faith. The novel's simple narrative belies a sophisticated distillation of New Theology, with a focus on Christ at the center, an emphasis on subjective interpretations of faith, and an insistence that redemption must be communal. Sheldon's subsequent novels extend this depiction of liberal, social Christianity in action, focusing in on specific sub-groups of American society but always echoing the refrain, "What would Jesus do?" In His Steps, itself, testifies to Sheldon's own conviction that American Christianity had become "nominal," resulting in the growing calamities of urban life, in enmity between races, and in widespread immorality on many levels. In the novel, Sheldon refers to society's depravity as a "crisis," a "genuine crisis," and a "crisis of feeling" that pervades the town of Raymond; but he also argues that this crisis is the fault of an anemic, misguided Christianity that has hidden behind the walls of the church and failed to take ownership for its community. ${ }^{81}$ Surrounding the church there is great need, extraordinary depravity, and multitudes of the unredeemed, Sheldon reminds readers. The fictional Reverend Maxwell (a

80 See Miller 71-92. Miller's account of Sheldon's bestseller appears to include the most in-depth research, and he acknowledges, while other scholars simply recount unverified assumptions about the novel. Miller states, "The story of the writing, publication, and circulation of In His Steps has been told many times... Rarely has the story been told accurately. Many exaggerations and myths quickly grew up around the book, and many of those who have written accounts marveling at its great success have never stopped to separate fact from fiction" (66). The novel was enormously successful, however, and while tens of millions of copies were likely sold, readership went beyond that figure. Among Christian circles, the story became a cultural phenomenon, not unlike Uncle Tom's Cabin half a century earlier. The tale was turned into a play, a radio adaptation, a comic book, a "lantern-slide" photo play, and was even used to advertise everyday items, such as a pair of "Men's Very Fine Blue Serge Suits" at a shop in Topeka (Miller 87-91).

81 Sheldon, In His Steps, 19, 22, and 55. 
thinly veiled Sheldon) admits to being "conscious of a great upheaval in his definition of Christian discipleship," and takes as his sermon text 1 Peter 2.21, which states, "For hereunto were ye called: because Christ also suffered for us, leave us an example, that ye should follow his steps. ${ }^{.82}$ Christ's teachings, Maxwell decides, are to be the center of this new era of discipleship - a practical way for believers to reform the city and win souls for Christ. ${ }^{83}$ The next Sunday, Maxwell solicits volunteers from his congregation "who will pledge themselves, earnestly and honestly for an entire year, not to do anything without first asking the question, 'What would Jesus do?' And after asking that question, each one will follow Jesus as exactly as he knows how, no matter what the result may be. ${ }^{\prime 84}$ The subsequent chapters examine their challenges and victories in living this new Christian Socialism, and the story details how the humble efforts of a few churchgoers transform the city's slum and spark a movement that reaches all the way to Chicago.

If In His Steps became a kind of modern New Testament for Christian Socialism, its first role was to establish the movement's cardinal principles of discipleship and sacrifice. The power of practical Christianity, as evidenced in In His Steps rested on each individual's commitment to living sacrificially, according to what Sheldon called the "test of discipleship." Taken directly from Jesus's teachings, which Sheldon believed were the blueprint of the Christian life, the concept of discipleship separated what he called "nominal" Christians from those who were truly modern disciples of the Savior. In an essay written for Zion's Herald in 1898, Sheldon reproduced a discussion on discipleship that echoed and, in fact, pulls direct quotes from, the final chapter of In His Steps. Likely Sheldon reiterated this extended definition of discipleship

82 Ibid, 7.

83 Ibid, 22.

84 Ibid., 21. 
because it was the crux of his entire vision for Christian Socialism. He writes: "Christian discipleship means no less today than it did in Christ's own time. [...] That discipleship called for the willingness to surrender anything to the Master's service." ${ }^{85}$ This meant "tak[ing] up the cross daily to be His disciple" and following wherever Jesus leads, no matter what the cost. ${ }^{86}$ Sheldon quotes and paraphrases multiple New Testament passages, essentially arguing that, for Christianity to be effective in the world and for Christ to continue to expand his kingdom, believers must put all their resources, relationships, power, and even their very lives into his service. Here is Sheldon's theological vision and training on display, as he extends a typological definition of disciple from the early Apostles to modern day believers, testifies to God's immutability (consistency over time), reflects on Paul's teaching on reconciliation ("if any man be in Christ, he is a new creature"), and underscores the role of individual will in responding to Christ's call. But, to Sheldon, such theological exposition does not have mere intellectual aims. Rather, if American Christians are willing to meet with the "test of discipleship," the implications will be felt throughout society. In the final pages of In His Steps, Rev. Maxwell asks, "Are the Christians of America ready to have their discipleship tested? [...] Is it not true that the call has come in this age for a new exhibition of Christian discipleship? [...] Would it not be true, think you, that if every Christian in American did as Jesus would do, society itself... would be so changed that human suffering would be reduced to a minimum?" 87

Second, in addition to discipleship and sacrifice, In His Steps illustrated that Christian Socialism would have a greater effect if it focused on training the next generation in the ways of practical Christianity. By participating in the church's social mission, young people could, at

85 Sheldon, "The Law of Christian Discipleship," 265.

86 Ibid.

87 Sheldon, In His Steps, 246-247. 
once, throw off America's tendency toward "nominal Christianity" and steer their generation toward equality, morality, and opportunity. This focus on youth permeates In His Steps, as various young men and women grapple with how, exactly, to dedicate their lives to Christ and how to reach the downtrodden who live in The Rectangle. Throughout the story it is youth from Endeavor societies who take the lead in pledging to "do as Jesus would do," leading to a "life and a power" in their churches that was "like a new birth for the members." ${ }^{\text {}}$ Each believer interprets Christ's leading individually, a reminder of George Harris's insistence that subjectivity could connect the next generation of believers to the leading of the Spirit, resulting in new, invigorated interpretations of objective truth. The novel ends with Reverend Maxwell experiencing a vision that includes "Endeavor Societies all over the world carrying in their great processions at some mighty convention a banner on which was written, 'What would Jesus do?'” Then, "in the faces of the young men and women" Maxwell believes he can see "future joy of suffering, loss, self-denial, martyrdom" as "the Son of God" beckons to them in the distance. ${ }^{89}$ As the real life Reverend Maxwell, Sheldon's own years of ministry reflect a commitment to young people: he worked fiercely to establish the Tennessee Town Kindergarten (after visiting kindergartens in the Northeast to study their role in child development); he closely oversaw the Christian Endeavor Society at Central Church and traveled nationally and internationally on the part of Christian Endeavor; he established a library in Tennessee Town; he supervised a variety of groups and clubs at Central Church which provided spiritual guidance, skill training and even food and clothing to families in the community (black and white); he edited an accessible version of the bible called The Everyday Bible to appeal to high school and college students; and he even tailored his sermon-stories to follow the academic calendar, so

88 Ibid., $182-183$.

89 Ibid., 254. 
Washburn College students would attend Sunday evening services. ${ }^{90}$ Perhaps the greatest evidence of Sheldon's commitment to all youth, white or black, was reflected in his genuine affection for the children of Tennessee Town. Through the years he was a frequent visitor at the Tennessee Town kindergarten and, as Charles Sheldon Sudduth later attested, he was "held in near-reverence" by the children. At one point, when Sheldon became ill, the students sent him a gift to raise his spirits. Sheldon responded by writing a short, but powerful, verse in their honor:

"My brother of whatever tongue or race,

Whatever be the color of thy skin;

Tho' either white or black or brown thy face,

Thou art in God's great family-my kin. ${ }^{91}$

Through a variety of genres and arenas, then, Sheldon allowed his writing to advocate for a more compassionate and sacrificial Christianity that mirrored the disciples' call to service. Nowhere is this message more evident than In His Steps, as the novel celebrates what is possible when believers fuse the social and the spiritual into practical, earthly ministry. But In His Steps does not explicitly address race, just as the majority of social gospel fiction broadly addressed issues of poverty, vice, and discrimination without explicitly naming race. Perhaps for this reason, among others, In His Steps has long been criticized for being "decidedly unrepresentative of American society as a whole," with characters who are "all well fed, well educated, well off, middle or upper class mid-western small town WASPs."92 But in most cases, that was Sheldon's

90 Miller, 35, 67, 173. In regard to Christian Endeavor, a December 1900 Congregationalist article discusses Sheldon's tireless work for the Christian Endeavor movement "on both sides of the Atlantic." Sheldon's "eight month campaign" included speaking at the London Endeavor Convention then traveling from Eastport, Maine, to Savannah, Georgia, with many stops in between. The article notes that, "since September he has been speaking constantly, sometimes three or four times on a week day and occasionally as often as seven or eight times on Sundays." See “Mr. Sheldon's Eight Months' Campaign.” Congregationalist 85.52 (29 Dec. 1900):967. 91 Sheldon qtd. in Miller, 56.

92 Shepherd, 2. 
audience - the very people whose faith he hoped to revive in order to reach the underprivileged in society who surrounded them. If he was to "Christianize the Negros by Christianizing the Anglo-Saxons," he had to first convince white, Protestant Christians of some means to join his movement. Sheldon's actions at the time (as well as the activities of his church), however, reveal that Central Church was very much a congregation dedicated to racial equality and to the crossing of racial borders. To them, practical Christianity meant facing the challenges of discrimination and inequity in nearby Tennessee Town, hoping to ensure that the next generation of believers—-white or black or brown"-would work together to realize Christ's kingdom on earth. To tell of their work, Sheldon would write The Redemption of Freetown, a culmination of his goal to "Christianize the negro by Christianizing the Anglo-Saxon." Like In His Steps, the novel was first read as a sermon-story, but this time, reflecting Sheldon's commitment to youth, he read the tale directly to Central Church's "Young People's society of Christian Endeavor." It is his most radical and exciting call for racial equality, and Redemption portrays Christian Socialism as a crucible for race relations, refining Christ's gospel into meaningful social and spiritual transformation.

\section{From Tennessee Town to Freetown}

To define the Social Gospel Movement, many scholars quote one of the its leading visionaries, Shailer Mathews, who characterized its approach as "the application of the teaching of Jesus and the total message of the Christian salvation to society, the economic life, and social institutions... as well as to individuals." ${ }^{94}$ Certainly this is a good starting point, yet this

93 Sheldon, "Introduction," The Redemption of Freetown. 1898. Celebration, FL: Kincaid Books, 2014. v. 94 Shailer Mathews, "Social Gospel." A Dictionary of Religion and Ethics. Ed. Shailer Mathews and Gerald Birney Smith. New York: Macmillan, 1921. 416. For a helpful overview of Social Gospel scholarship, as well as its 
definition fails to include, directly, any concern with race relations and racial reform. The assumption is that the Social Gospel focused on larger agendas (economy, labor, poverty) and any impact on racial justice was a byproduct of these aims. But, in fact, social Christianity, especially in its early days, evolved in direct response to racial inequality—something Ralph Luker demonstrates with impressive historical detail in his groundbreaking work The Social Gospel in Black and White. Initially, the movement took shape in outposts and small communities across the nation, where grassroots church initiatives (in white and black congregations) responded to the challenges of racial inequality with practical reforms. They educated children, trained adults in job skills, provided food and other necessities, and even established "missionary" settlements within black neighborhoods. In short, these believers sought practical ways to apply Christian principles to the persistent American racial divide. But, in scholarship, a disconnect between Social Gospel and race reform histories has persisted. James McPherson argues that the Social Gospel Movement was caught between competing strains of racial reform - the radical and gradualist approaches — so that after 1875, the Social Gospel movement, itself, "reflected these kaledescopic patterns," and historians either "fail to understand the complexity" or ignore the issue of race altogether. ${ }^{95}$ By reexamining Sheldon's pioneering approach, then, the strains of Social Gospel and race reform can be brought into harmony.

In 1892, just after Sheldon's “sociological experiment” living with the residents of

intersections with racial reform, see also Ronald C. White Jr. and C. Howard Hopkins. The Social Gospel: Religion and Reform in Changing America. Philadelphia: Temple University, 1976.

95 James McPherson, "Foreword.” Liberty and Justice for All: Race Reform and the Social Gospel, 1877-1925. By Ronald C. White Jr. Louisville: Westminster John Knox, 1990. ix-x. Few scholars have directly addressed the Social Gospel Movement's racial focus, but explorations by Luker and Ronald C. White Jr. provide useful starting points. See Ralph E. Luker, The Social Gospel in Black and White: American Racial Reform 1885-1912. Chapel Hill: University of North Carolina, 1991.; and Ronald C. White Jr. Liberty and Justice for All: Race Reform and the Social Gospel, 1877-1925. Louisville: Westminster John Knox, 1990. White's brief discussion of Sheldon appears on pp. 30-35. 
Topeka, he undertook to fundraise for a new kindergarten in Tennessee Town. ${ }^{96}$ There already existed many kindergartens throughout Topeka, with the earliest one founded during the Civil War, and kindergartens were largely believed to be "the most hopeful form of social regeneration. ${ }^{.97}$ But while missions, institutional churches, and other charitable organizations established kindergartens throughout the frontier state (some integrated), there were no all-black kindergartens - not in Topeka nor anywhere else west of the Mississippi. Sheldon lamented this oversight, believing that "the great hope for the negro, as for any other man, lies in the children of the race," and, in response to the need he established a kindergarten as the first of many efforts to confront the "local negro problem in [his] own parish. ${ }^{98}$ The school was a boon to the community and benefited children who attended; they engaged in creative projects, learned order and focus, played games, formed a band, and even grew a garden with produce they could sell or take home to their families. At first, residents of Tennessee Town were reticent to accept white workers into their community, but in just a short time the school was a success and "Sheldon had gained a foothold in Tennessee Town. ${ }^{, 99}$ Sheldon and his congregation built relationships with members of the community—part of Sheldon's commitment not to know "mankind" but to know "men"-and because residents were in great need, Central Church responded with what Miller

96 Miller writes that one of Sheldon's first contacts with Tennessee Town residents involved a run-in with Jordan. Sheldon, "the self-described 'rabid prohibitionist' had urged raids on Andy Jordan's speakeasy." But just a year later, Jordan agreed to lease his space for Sheldon's kindergarten (49).

97 Patty Smith Hill. History and Theory of Early Childhood Education. Samuel J. Braun and Esther P. Edwards, Eds. Belmont, CA: Wadsworth, 1972.

98 Sheldon, "A Local Negro Problem," The Kingdom 8 (10 Apr. 1896):828.

99 Miller, 51. In Liberty and Justice for All, White mentions that by 1896, enrollment at Sheldon's kindergarten reaching 210 children, and the school continued on for twenty years until it was taken over by the city school board. White also laments what he calls "the language of paternalism, yet such a term seems disingenuous and anachronistic for a reformer whose Tennessee Town work "didn't just provide gifts, but seriously promoted selfhelp. It wasn't just a palliative program, but an integrated mix of relief and educational endeavors, with a strong emphasis on helping people get jobs in a time and situation where they were hard to come by." Still, Miller acknowledges, "the program certainly had its naïve moments and some relative weaknesses," but he concludes, "on the whole it was more coherent, and did a lot more good, than a great many more costly and elaborate programs do today" (Mille r65). 
calls a "balanced social gospel." Congregants conducted educational programs for the children's parents (sewing classes for the mothers and older daughters; basket weaving and gardening for the men), taught residents to grow gardens, hosted a library and reading room in the classroom space after school hours, and offered music and other cultural entertainment (the Fisk University Jubilee Singers performed a series of concerts to interracial audiences). ${ }^{100}$

The relationship between Sheldon's white congregation and the all-black neighborhood was truly remarkable in its time and, in fact, as Ralph Luker has shown, much of the early foundation for institutional churches - pre-1900 — came from black churches "in denominations outside the mainstream." ${ }^{101}$ These churches in New York (Harlem), Philadelphia, Atlanta, and so on prefigured the broader institutional church movement, which was later espoused by African Methodist Episcopal (A.M.E.) pastor Reverdy Ransom in Chicago in 1900 and onward. Ransom's ministry, like Sheldon's, was an interracial and interdenominational endeavor, as Ransom worked with white reformers Jane Addams, Bishop Samuel Fallows, Robert Ingersoll, Shailer Mathews and others to remind American Christians that "the problem of racial discrimination and inequality should not exist in a nation founded on the teachings of Christ. ${ }^{102}$ Similarly, Sheldon placed an emphasis on the gritty service of laypersons, and at his Central Church white and black Christians worked together to lead social programs, and, on Sundays, worshipped together in interracial services (Sheldon's church welcomed black

100 Miller, 50-62.

101 Luker, 171.

102 Gary Scott Smith, The Search for Social Salvation: Social Christianity and America, 1880-1925. Lexington: Lexington Books, 2000. 218. Smith goes on to quote Ransom, who wrote that Jesus "lived in the midst of the most bitter and intense antagonisms of race and class, and yet he ignored them all, dealing alike with Jew, Samaritan, Syro-Phoenician, Greek and Roman." Jesus had died, Ransom reasoned, "to break down the middle wall of partition" between people, and he argued that if the segregation endorsed by American "Christianity" in the twentieth century was supposed to be "the spirit of Jesus. . then give us Mohammed or any other redeemer." (qtd. in Smith 218). For more on Ransom and his social gospel writing, which came after Sheldon's early writing, see Anthony B. Pinn, Making the Gospel Plain: The Writings of Bishop Reverdy Ransom. Harrisburg, PA: Trinity Press International, 1999. See also Luker, especially 170-178. 
congregants and was likely one of the first to integrate services after the War). ${ }^{103}$ In keeping with the spirit of ecumenicalism, many of the programs at Central Church included volunteers from nearby churches of differing denominations. Overall the settlement approach to Tennessee Town was organic in structure, with room for each person to act as they were called, meeting needs as they arose. When Sheldon noticed the lack of medical care in Tennessee Town, the group from Central Church located physicians who agreed to treat patients free of cost. Lawyers gave free legal advice, and Sheldon's own father-in-law issued interest-free loans for needy individuals. As for home ministry, committees of individuals visited the elderly and shut-ins, distributed food and clothing throughout the neighborhood, provided a nursery for busy mothers, and assisted residents in cleaning up their yards or growing gardens in the summer that would feed them through the winter. ${ }^{104}$

By 1898 the Tennessee Town ministry was such an overwhelming success that Sheldon decided it would make a fitting and, this time, historical fiction-based sermon-story-a way to show the world what true discipleship could accomplish, even in a contentious racial landscape. He crafted The Redemption of Freetown first to read to his Christian Endeavor group, and, second, to speak to his then-widespread and eager reading public. The slim novel is, in message, a retelling of Central Church's work in Tennessee Town, as it focuses entirely on one (white) community's relationship to the neighboring (black) slum. The tale testifies to Sheldon's lifelong commitment to racial equality and illustrates the local efforts of his parish to work with and for the African Americans in Tennessee Town; but it also reveals the state of race relations in

103 Sheldon also shared ministerial duties with black pastors in Tennessee Town, and Central Church supported the work of the neighborhood's Second Colored Congregational Church, which had been established years prior (Miller 62).

104 Miller, 50-62. In "A Social Experiment," Sheldon writes of the Village Improvement Society his church formed with Tennessee Town residents, to rid their yards of trash and overgrowth and even grow produce. Various prizes were offered for the most transformed segments of the neighborhood. 
America at the turn-of-the-century — the fears sparked by racial integration, the deep racial divide that kept whites and blacks in separate social spheres, and the growing sense that Christianity must somehow address this inequity, for the good of the society and for the furtherance of the kingdom. Most importantly the novel is a succinct culmination of Sheldon's vision for Christianled racial reform movements.

Due to the novel's obscurity, a brief overview of its plot is likely useful. The story opens in a packed district court room, as Judge John Vernon pronounces a twenty-year sentence on a "young negro not more than twenty years old" who has just been convicted for "a shooting affray" in the black neighborhood of Freetown. ${ }^{105}$ The young man, Burke Williams, protests his conviction, saying the shooting "was accidental" and counters, "If I'd had a fair trial, I'd been let off. But everything's against me here." 106 The incident haunts Vernon, who is troubled by the "condition of affairs" in Freetown, a black slum where "the hardest, worst elements in the city are crowded." 107 The area sits next to the "best residence part of the city," and Vernon's own son Claude has been drawn into its drunkenness and lawlessness - to the point that Vernon fears one day his own son will appear before his court. ${ }^{108}$ From the opening, then, Sheldon immediately presents a battleground of race relations: a society where individuals perceive a distinct border between whites and blacks, the redeemed and unredeemed. But while Vernon's wife and daughters fear that black depravity is tainting their lily-white existence, the Judge insists that the inhabitants of Freetown, too, are suffering and that their impoverished conditions are a burden to be borne by the whole community. Vernon's minister, the Reverend Howard Douglass, of the

105 Sheldon, The Redemption of Freetown. 1898. Celebration, FL: Kincaid Books, 2014. 1-3.

106 Ibid., 2.

107 Ibid., 3.

108 Space does not permit a thorough discussion of the book's critique of alcohol, but the novella certainly reflects Sheldon's prohibitionist stance. Alcohol never passed through the minister's lips, and he believed the saloon was the breeding ground for much of society's lawlessness and immorality. For more on Sheldon's endorsement of prohibition, see Miller, 164-172. 
aptly-named Emmanuel Church, comes to a similar conclusion about Freetown's need after spending time with the residents of Freetown in a Sheldonesque sociological experiment. Douglass enlists Vernon's help and the two set out to rally the rest of the congregation to establish a settlement presence in the neighborhood. In his Sunday sermon, Douglass tells his white congregation, "I believe the Judge of all the earth will condemn the Christian disciples of Merton in the last great day if they do not... personally throw the strength of their lives into the solution of this problem." ${ }^{109}$ Soon after Douglass issues his challenge, Williams escapes from prison and, while he eludes authorities, Vernon's lawless son dies after a late-night assault. Public opinion immediately condemns Williams who, seeing no way out, commits suicide. The remainder of the book details Emmanuel Church's efforts working for and with their black brothers and sisters for social and spiritual redemption, as the tragic deaths of two young men become a rallying sacrifice. After just sixty-four pages of narrative, the book ends fifteen years in the future, with a journalist remarking on the changes in Freetown and asking, "Shall the world ever be redeemed in any other way?"110

As a simply crafted and straightforward novella, The Redemption of Freetown extends Sheldon's vision for Christian Socialism in three main ways: by emphasizing the discipleship principle of self-sacrifice, by channeling the power of Christ as Emmanuel (meaning God was with his followers in their social endeavors), and by reconceptualizing salvation as communal. Sheldon's brief introduction to the novel speaks to each of these teachings, as he writes that modern day disciples must be willing to follow Christ's example of sacrifice in their own lives, accessing God's power through Emmanuel, and bringing a "miracle of redemption" to the whole community. To encourage sacrifice, specifically, Sheldon tells readers (and, originally, the youth 
of Christian Endeavor), "There is nothing impossible in the story, which is largely founded on actual facts. What seems to be miraculous or impossible in the redemption of humanity seems so because too often the Christian disciple does not give himself for the solution of the human problem." ${ }^{111}$ Sheldon is not asking for believers just to contribute resources or time to the cause of racial equality, but argues for believers crossing literal and figurative racial boundaries: "The moment the churches, the Endeavor societies, the Christian disciples everywhere, put themselves into any unredeemed spot in any town or city or place, the miracle of redemption will begin."112 In other words, the act of sacrifice collapses distance, bringing each disciple closer to his brother, just as the original Sacrifice brought God closer to man.

Susan L. Mizruchi writes that, in the late nineteenth century, there was a "preoccupation with sacrifice" not only among believers but also in a variety of texts that addressed the "idea of society" (social science texts, literary narratives, and "renovated theology" alike). She links this to the root term for "sacrifice" in Hebrew, which is korban, meaning "to bring near." In relation to the divine, Christ's sacrifice enables a redemptive relationship between God and man—it "brings near" the believer by atoning for sin. But in the late century "atmosphere of spiritual crisis," "waning doctrinal commitment" and challenges "posed by science to the social dominance of religion," sacrifice could also "fortify social bonds." ${ }^{113}$ In her study Mizruchi finds that, "sacrificial rites are often identified with periods of social instability in general" and with "social heterogeneity in particular." ${ }^{\text {. } 114}$ At the turn-of-the-century, American society faced such instability on a variety of fronts, not the least of which were issues regarding race. In the $1890 \mathrm{~s}$, as Sheldon's career took off, lynching and other acts of racial violence were reaching their

111 Ibid., v (emphasis mine).

112 Ibid., v (emphasis mine).

113 Susan L. Mizruchi, The Science of Sacrifice: American Literature and Modern Social Theory. Princeton: Princeton University, 1998. 26.

114 Mizruchi, 26. 
zenith—not just in Jim Crow south, but throughout the Union. Closer to Sheldon, the state of Kansas had mandated school segregation from 1859 on, and by the 1880s and 90s race violence struck home in Topeka specifically, with multiple lynchings and "a pattern of deliberate race oppression" in the city. ${ }^{115}$ Sacrifice, then, as Mizruchi defines it, contextualizes and clarifies Sheldon's endorsement of Christian Socialism - a blend of Christocentric sacrifice that would unite man with God as well as unite humankind in a community of believers. Followers of Jesus could enact spiritual and social redemption if they were willing to "give of themselves" just as Christ gave of himself.

In Redemption, Sheldon directly addresses why some of the townspeople are not willing to "give of themselves" to help Freetown: racial prejudice has led white Christians to distance themselves from African American need, rather than viewing blacks as fellow citizens or as fellow brothers and sisters in Christ. Judge Vernon, pensive after doling out a twenty-year sentence to Burke Williams and fearful of his son's own reckless behavior, says to his wife, "I cannot help but thinking of the people in Freetown. In the very heart of our Christian (as we call it) city there is a condition of lawlessness and impurity that very few realize... Eliza, somehow I cannot help connecting the crime in Freetown, the dissipation and immorality in that district, with the same thing in what we call our best society." 116 She responds, "It is horrible, as you say... But I do not see what connection there can be between the condition of things among the negroes in Freetown and that of the white people in the society we know." To put a finer point on it, after the family learns that Claude has been assaulted late one night, the Vernon daughters, Isabel and Winifred, lash out in racist anger and assume Williams has committed this crime as well: "Who else could have done it?," Isabel asks. "We all know the colored people have done 
just such things repeatedly. They are simply awful. They ought to be punished. I for one believe they were a good deal better off in slavery. It's where they belong." Winifred extends this desire for even more distance, by adding, "I feel the same. I think every negro in Freetown ought to be transported to Africa, so we could get Merton forever rid of them." ${ }^{, 117}$ Elsewhere in the novel, Sheldon's phrasing testifies to white perceptions of distance between them and the black community. Williams is deemed an "awful wretch," Freetown is considered the "lost part of [the] city" and "unchristian," and black residents of are referred to as "miserable creatures," "that class," and the "people who caused [Claude's] death." ${ }^{, 18}$ To further highlight the racial divide, Sheldon characterizes the skewed legal system as eager to put Williams in a "cage." ${ }^{.119}$ When Williams breaks free from prison, he "seeks refuge in his old haunts in Freetown," indicating the larger "cage" of black existence in the city and the fact that no amount of distance will truly create a refuge.

Sheldon called such racism "the prejudice of caste" in an essay for The Kingdom, and stated, "I have never been able to get any person with this caste prejudice against the negro to give me a good reason for it. When everything has been said, all that is left is the statement, 'I don't like the nigger." He resolved that, "the only answer to this local negro problem... is the same answer which must be given to the Human Problem everywhere. A true Christian cannot draw a color line to shut a human being out of any avenue of progress and existence. A black man is made in God's image as much as any white man." ${ }^{120}$ In other words, only by convincing white Christians to see the humanity of blacks - to see them as human beings created in God's

117 Ibid., 20.

118 Ibid., 32, 38, 37, 20, $11 \& 32$.

119 Ibid., 4-5. Sheldon is purposeful with this term, using the word "cage" three times to refer to Burke Williams's confinement in prison. The minister believed wholeheartedly that every person should be treated equally before the law-men, women, black, white, Protestant, Jew, or Catholic — and any political enactment of prejudice. See Miller, 156-158.

120 Sheldon, “A Local Negro Problem,” 828. 
image and imbued with the same rights and value of any other person—could he illicit their help in countering racism. There was no answer for racism, Sheldon found; instead, he had to shift the focus to ask Christians what the Example of humanity, Jesus Christ, would do in their place. In this way, Redemption acts as a sequel to In His Steps, answering the question "What would Jesus do?" with the answer "give of himself."

Sheldon uses the phrase "give himself" (or an equivalent) eleven times in Redemption, and at often reminds readers that dedicating oneself to Christ means giving of certain talents and resources, as well as giving up certain earthly comforts. When Reverend Douglass enlists members of Emmanuel Church to aid Freetown, he proposes that the best way to help the community is to have members of the church relocate there - to live and work alongside, and to really get to know, intimately, the black residents. The settlement house must contain Christians year-round, he says, who will "give their talents, their strength, their wisdom personally to a solution of the terrible problems over there." ${ }^{\prime 21}$ As Douglass continues to gain recruits for the Freetown mission, Deacon Culver promises to "give all he can," the Douglasses themselves agree to "reside in the [settlement] house part of the time and give [their] personal attention" to the work there, and soon even the Hon. William Brooks (a lawyer) sheds his initial skepticism to "give himself, where for so many year he had simply given his opinions." 122 This willingness to give initiates a flurry of practical activity that brings the members of Emmanuel Church closer to one another and closer to regarding Freetown residents as worthy of sacrifice. Their actions begin to unify area churches by bringing in a Mr. Carlton, who "was almost a stranger, and belonged to another denomination." 123

121 Sheldon, The Redemption of Freetown, 40.

122 Ibid., 24, 42, and 45.

123 Ibid., 35 . 
This message of self-sacrifice in Redemption may have been influenced, in part, by Sheldon's connection with Social Gospel leader George Herron-one of the movement's most intellectual theorists. Sheldon read Herron's works and corresponded with him in the 1890s, and Sheldon certainly would have agreed with Herron's insistence that that, "The redemption of society would come only through sacrifice on the part of individual Christians." ${ }^{124}$ In 1894 Herron hailed a "new Christian order," in which the "political and social apostles of Christ must be as truly dedicated to be sacrificed for the coming of the kingdom of God as were the primitive disciples of Christ." 125 Such sentiments reverberate in Sheldon's essay "The Law of Discipleship," where he writes, "The discipleship of Jesus now is bound by the same law that bound the first Christians... I do not mean to say that every disciple must be a martyr... but be a loser of property, in order to follow Him. I say only that if the test of discipleship results in martyrdom or earthly loss, we are not to resent such a result." ${ }^{126}$ In Redemption, Douglass's sermon communicates a similar exhortation to personal sacrifice, when, in regard to Freetown, he asks, "How much money have we ever spent over there? How much time have we ever given from our receptions and parties and entertainments to teach Freetown the way to eternal life?" Douglass then insists the "Judge of all the earth will condemn the Christian disciples of Merton in the last great day" if they fail to "give up their endless round of pleasure-seeking and waste of God's wealth, and personally throw the strength of their lives into the solution of this problem."127 Once again, Sheldon asserts that disciples must choose the way of sacrifice-a calling that has been the same from the first century of Christendom onward.

From cover to cover Redemption echoes a refrain of self-sacrifice but, while the focus is

124 Herron qtd. in Miller 140-141.

125 George Herron, “The Great Oration.” Wealth Makers. 21 June 1894. 1-8. 8.

126 Sheldon, "The Law of Discipleship," 265.

127 Sheldon, The Redemption of Freetown, 17. 
on earthly ministry, the believer must acknowledge the power of redemption comes from Emmanuel — the incarnate Savior who brought God to man. In the introduction, Sheldon states that the "one great truth" he "wished to impress by the telling of this history" was the "truth that it is God with us, Emmanuel, who is redeeming the world, and it must be ourselves, the Christ in us, with the unredeemed humanity near us, that must redeem it." ${ }^{\prime 28}$ As "God with us," the concept of Emmanuel held immense power for Sheldon, because work of social reform and redemption was not a mere human endeavor, nor was it subject to the whims and turmoil of human history. Instead, Sheldon insists that he and all believers who worked for social and spiritual betterment were working with God and through God's power. The creator had come to earth as Emmanuel (the incarnation), had given his life as a sacrifice (the act of atonement), and was continuously working in the lives of believers (the process of sanctification) to bring Christ's redemption to the world. Here again, Jesus is the focus of Sheldon's theology, as it is Christ who provides a direct line to God and it is "Christ in us" who enacts change in the world.

As Sheldon wrote in "The Law of Christian Discipleship," the very definition of a Christian is "a new man in Christ." This implies that, as the Apostle Paul writes in Galatians: "I am crucified with Christ: nevertheless I live; yet not I, but Christ liveth in me. ${ }^{, 129}$ Here the work of Christ's sacrifice through the atonement is complete, as distance collapses and Christ lives through the believer, in word and deed. So when Sheldon asks, "What would Jesus do?" Christians must answer the question with a life of service, allowing Christ to work through them in both earthly and spiritual aims. Finally, Emmanuel parallels New Theology's emphasis on the "person of Christ." As stated earlier, emerging liberal theologians focused on Christ's humanity

128 Ibid., v.

129 Galatians 2.19 (King James Version). In "The Law of Discipleship" Sheldon also quotes numerous verses from the New Testament regarding regeneration, including II Corinthians 5.17 ("if any man be in Christ, he is a new creature. Old things have passed away; behold all things have become new"). 
to illustrate that God could relate to human experience; they were encouraged to follow the Example and do the same, by identifying with those in need around them. As Sheldon writes in "Practical Sociological Studies," the church must "put into actual motion some of the unapplied power of Christianity... heartfelt sympathy for humanity, his identification with it, and his application of the Christ spirit to its needs." ${ }^{, 130}$ Indeed the spiritual and human power of Emmanuel weaves through Redemption, as Howard Douglass's church is named Emmanuel Church and the novel's final line quotes from the Annunciation in Matthew: "And they shall call his name Emmanuel, which being interpreted is, "God with us."'131

Perhaps the greatest lesson of The Redemption of Freetown, however, is Sheldon's insistence on Christian community, a hallmark of the Social Gospel. The Kansas minister believed, wholeheartedly, that one soul's redemption was the spark that could ignite a family, church, neighborhood, or town. The book follows this path as, one by one, the citizens of Merton re-examine their commitment to faith through sacrifice and join the effort to "redeem" Freetown. The congregation is an amalgam of believers - those with great financial resources like Mrs. Carlton who contributes thousands of dollars to the building of the settlement house; those with collective power, such as the unnamed women of the United Clubs of Merton, who, after some discussion, finally agree to do their part to raise funds; the town's youth, embodied in Inez, Claude's intended, who seeks to redeem his memory by volunteering for Douglass's "errand" in the Freetown wilderness; and there are those with means like William Brooks, a lawyer, who must put aside skepticism to answer the call. Ultimately Sheldon believed the church's work should center on changing society by changing individuals, as social structures were largely corrupt and immovable. And Redemption illustrates how the message of collective redemption 
spreads through meaningful relationships in Christ's kingdom, even as word of Freetown's transformation finds a national audience by the novel's close.

Remarkably, however, while Redemption's aim is to strengthen the community of believers, the novel ends just as the Freetown settlement is dedicated, closing readers off from any glimpse at Freetown's true redemption. Further, the novel neglects to incorporate black perspectives, which Sheldon so valued in his own ministry, and Burke Williams is the story's sole representative of Freetown (speaking his only words when he is out of Freetown and in Merton's courthouse). This exclusion of black voices, however, may be due to Sheldon's ultimate goal: he did not write Redemption to chronicle African-American experiences but to depict injustice and inequality so that his congregation and Christians as a whole would take action. For this reason he offers a brief account of the redeemed Christian community in the novel's final chapter, in a letter from journalist Alfred Harris, who has purportedly been asked to profile Freetown's settlement house work. Harris writes that Emmanuel Church's plans have been "carried out with the most remarkable results" and that "a volume might be written about" the success of the kindergarten alone. ${ }^{132}$ One by one, Harris remarks on the reforms enacted in Freetown, with careful attention to improvements made across the color line. He briefly notes how the changes have helped to improve conditions for black residents stating, "You would be astonished to see what has been done."133 And the letter details ways in which Emmanuel Church's congregants have experienced personal transformation by giving of themselves, illustrating the edifying effects of believers who truly live according to imitatio Christi. Finally,

132 Sheldon, The Redemption of Freetown, 56. Miller also discusses the effects of Sheldon's Tennessee Town settlement and describes a measurable decrease in crime, improvements to the community's appearance, and better resources for residents. He notes that, at various points in the settlement work, those involved represented "most of the major Protestant denominations in Topeka," and he concludes, "Tennessee Town provided an early, practical demonstration of social reform through ecumenical outreach." See Miller, 63-65.

133 Sheldon, The Redemption of Freetown, 57. 
Harris concludes with a challenge for all members of Christ's kingdom: "Fifteen years seems like a comparatively short time to redeem a place such as Freetown was. But it is the personal life going into the heart of the great need that has done it. Don't you think it is because Christian people do not generally do the work on a large enough scale that the results are so small?"134 For Sheldon, it was time to re-envision what was possible through a socially-engaged faith in Christ and he places the burden squarely on white Christian audiences who must realize this is "no miracle, unless we call the love for lost souls a miracle."135

In addition to unifying outreach efforts, Sheldon argued that the notion of Christian community should elevate believers to a higher standard of conduct, based on shared responsibility in Christ's family. Both Judge Vernon and Reverend Douglass argue that the citizens of Merton have been entrusted with Freetown's care- that the district is not a scourge to be eradicated, but an opportunity to demonstrate Christian love through sacrifice and mutual ownership. Nowhere is this sentiment clearer than in Reverend Douglass's to Judge Vernon that, "Something ought to be done over there, or we shall have a heavy account to answer for at last, when the deeds of the body are summed up for judgment. The Christian people of Merton will be held largely responsible, I believe, for failure to help Christianize that spot." ${ }^{136}$ Following this statement, a group of police officers arrives at Vernon's door and announce that his son Claude has been found in Freetown, the victim of a horrible and violent assault. Clearly the need for redemptive action is urgent and, quite literally, on his doorstep. Earlier in the novel Vernon remarks that "a judgment is hanging over this city, so fair in its outward appearance, yet so wrong in much of its human life" and presciently states, "Crime and immorality never can be

134 Ibid, 60. 135 Ibid., 61 . 136 Ibid., 13. 
confined to one spot in a city." ${ }^{, 137}$ In other words, the lives of Merton's citizens are already intertwined with Freetown and their responsibility to "the least of these" brothers and sisters cannot be ignored by erecting false racial boundaries.

In the end, Sheldon's vision of Christian community in Redemption aspires to a "best society" model of social uplift that celebrates communal salvation. This includes practical improvements to Freetown, so that the settlement can teach sewing, cooking, and trades. There are plans for a library and reading room, a dispensary, a day-nursery, a kindergarten. And workers will incorporate "village improvement" and "Sunday work" in Freetown-just like in Sheldon's Tennessee Town reforms. Contributions, therefore, are not gifts, but part of a holistic plan to elevate the level of opportunity for Freetown residents. But of course, the idea of white congregants building up their vision of the "best society" in a black neighborhood seems to imply a paternalist instinct, at least in part. And the phrase "best society" appears early on with distinct (and sometimes ironic) racial overtones, such as when Judge Vernon denounces "fathers and mothers of Merton" who allow their boys to pick up wreckless habits even while living "in the best society." Mrs. Vernon counters: "Do you think it is the best society, John?"138 Later, when Douglass is finalizing plans to start the settlement in Freetown, he says the "success of [the] plan is the voluntary residence in the heart of Freetown of some of the best men and women in Merton." Repeating the same phrasing, he goes on to ask, "Can we get people, the best and best-known... to go over there and live? [...] not a few weak, uneducated, unequipped good people, but the best we have in the social and literary and political life of Merton."

The statements are surprising, coming from the egalitarian Sheldon-a man who insisted

137 Ibid., 11.

138 Ibid., 9.

139 Ibid., 37 (emphasis in original). 
on racial equality, despised the effects of greed, placed little emphasis on material wealth or power, and once stated he thought "the human race needs to be reminded that the lack of things is not in itself a curse." ${ }^{140}$ But Sheldon knew his white audience held the power in their communities, had the resources to share with black neighborhoods, and could take the lead in reconciling both sides of the racial divide. As evidenced in Redemption, it is essential for Reverend Douglass to win over the city's most talented individuals and citizens of means, because doing so assured success of expensive programs and initiatives. Mrs. Carlton contributes a large sum of two thousand dollars to the settlement house, and the Reverend Douglass states, "I have suggested that she use her influence to get other society people in Merton to share in the work. In fact, the redemption of Freetown ought to be part of the whole city's life... If we can only get the help of all the people who have means, we can do wonders in Freetown." ${ }^{, 141}$ In some ways this is Sheldon's way of asserting that "To whom much is given, much is required," and such a stance aligns with the aims of the Social Gospel Movement, which criticized society's powerful and wealthy for not doing enough to alleviate suffering and inequity. In his ministry Sheldon insisted that everyone be "willing to do the humblest Christian work." "142

Finally, The Redemption of Freetown issues a new, modern Great Commission. Through In His Steps Sheldon issued a challenge for social Christianity by asking, "What would Jesus do?" and he hoped believers would respond with deep reflection on how Jesus, himself, would live on earth and respond to the challenges of society. But in regard to the racial divide, Sheldon posed a new question to believers: "Who will go?" Through the voice of Douglass, Sheldon lays out the need for practical intervention in neglected black communities like Freetown (or

140 Sheldon qtd. in Miller 151.

141 Sheldon, The Redemption of Freetown, 34.

142 Sheldon qtd. in Devins, 69. 
Tennessee Town), and encourages his audience to consider the Christian life of self-sacrifice.

But here again it is the power of Emmanuel that motivates believers to go-to move beyond their sphere and channel Christ's power in human form. In Chapter VI, when Douglass asks members of his congregation "Who will go?" the question is a practical one-who will be willing to move into and be a part of the Freetown settlement, a decision that requires (white) individuals and families to relocate to a crime-ridden area of town, where they will live as the minority and need to work tirelessly to educate, train, and assist needy black residents. But the question also acts as a typological connection to biblical believers, from the commissioning of the Old Testament prophet Isaiah to the Great Commission issued by Christ in the New Testament. Both passages are instructive to Sheldon's vision for race reform, and both emphasize a willingness to expand the kingdom through toil and sacrifice.

In Isaiah 6, the prophet explains that he "heard the voice of the Lord, saying, 'Whom shall I send, and who will go for us?"” to which Isaiah replies, "Here am I; send me."143 This is sometimes referred to as Isaiah's Commission, and it comes after he glimpses the power of Yahweh and experiences forgiveness from the Most High. Isaiah volunteers himself for God's service, then, out of humility and gratitude - a willing sacrifice to be used by God in a tumultuous time in Israel's history. Isaiah's willingness to follow God's leading also delivers him to the promise of Emmanuel, as God entrusts him with the Messianic prophesy: "Therefore the Lord himself shall give you a sign; Behold, a virgin shall conceive, and bear a son, and shall call his name Emmanuel."144 This God incarnate, or God with us, is the very person who issues the Great Commission of the Christian era, continuing the line of humble sacrifice and a willingness to follow God's leading. When Jesus appears to his disciples following his death and 
resurrection, he exhorts them to "Therefore go and make disciples of all the nations, baptizing them into the Faith of the Father, the Son, and the Holy Spirit" $" 145$ The commandment is the same - to go — and the promise that follows again echoes the concept of Emmanuel, as he states, "remember, I myself am with you every day until the close of the age." 146 In a small, yet not insignificant way, Sheldon has the Reverend Douglass follow in this line of prophets, asking "Who will go?" on behalf of this modern Great Commission. To heal racial inequity, it was not enough to act as Jesus would in one's own sphere of influence; instead, as the success of the settlement house in Redemption illustrates, believers need to go out into the world and "give of themselves" so Christ, in and through them, can redeem the world.

\section{Conclusion}

If one were to examine The Redemption of Freetown in isolation, it would be remarkable for its brevity, for its simple (some may say simplistic) interpretation of Christianity, and for its honest acknowledgement of the turn-of-the-century racial divide in America. But in the context of Sheldon's liberal theology and his own extraordinary work in Tennessee Town, the novel becomes a culmination of his redemptive vision for American race relations. As Sheldon reflected in his autobiography, his sermon-stories did, indeed, "enlarge his parish" and "remove the feeling of limitations" he faced in the pulpit. The use of fiction allowed him the "latitude" to teach "certain vital lessons like love and the social side of life," and these homiletic stories

145 Matthew 28.19 (TCNT). All New Testament Scriptures are taken from the Twentieth Century New Testament, which Sheldon preached from in his Central Church in Topeka. For more on Sheldon's use of this translation, see Eberman, 201.

146 Matthew 28.20 (KJV) 
became powerful motivators for generations of Christians. The Redemption of Freetown is not a perfect story, but it is an instructive one that enlarges and particularlizes Sheldon's vision of social Christianity to include progressive views on race reform.

Second, as Sheldon crafted his sermon stories, he followed a larger Protestant trend of ministers addressing their congregations through narrative and anecdote, but while preachers like D.L. Moody and Billy Sunday told theological tales with an evangelical bent, to save individual souls, Sheldon adapted the genre for a "thoroughly progressive orthodoxy." ${ }^{147}$ What resulted, then, was a practical blend of liberal theology and popular literary device-a unification of the New Theology he learned at Andover and the everyday experiences in his frontier Kansas town. This cultural moment, just as the nineteenth turned into the twentieth century, signaled an ecumenical movement toward the institutional church as a way of addressing racism and inequity, and while reformers like Reverdy Ransom are more well-known for their social Christian endeavors, Sheldon was also on the forefront of this ministerial leadership. He sought a a wider audience than his pulpit would allow, and by turning to literature, Sheldon in a sense resurrected the sentimental tropes of pre-Civil War religious writing and hoped pathos would once again spur Christians to action.

Likely due to its radical vision, Redemption did not garner the readership of In His Steps, but its message testifies to the impact one frontier minister had on a racially-divided community, on regional and national conversations about race reform, and on decades of Social Gospel thought. In his last published article, printed posthumously in the Christian Herald, Sheldon reiterated his lifelong challenge to modern Christians, urging them to keep "making human beings better. Making them free from hatred, prejudice, greed, and selfishness." But even the

147 Phrase from Andover Review, 649. 
seeming simplicity of these words reverberates with a radical gospel message few could enact in Sheldon's lifetime and one that continues to elude believers today. 


\title{
Chapter 3: \\ Reading and Writing the Black Nazareth: Blood Identity and Bodies as Sacred Texts in Frances Harper's Iola Leroy
}

\author{
"What seemed to be a failure around \\ the Cross of Calvary and in the garden, \\ has been the grandest recorded success." \\ - Frances Harper ${ }^{1}$
}

Perhaps more than any other time in American history, the late nineteenth century was an era obsessed with blood, reflected even in the century's hymnody. Believers sang songs that spoke of "Calvary's stream" and its "cleansing wave," they hailed the "power in the blood" and "healing at the fountain," they were "saved by the blood," "washed by the blood" and "under the blood," and they even asked the unconverted, "are you washed in the blood?"2 At the same time, Americans were also obsessed with blood as a determiner of race-reflected in the wording of everything from legal documents to literature. Anyone with "contested racial identity" was assumed to be non-white and therefore faced a host of social and legal exclusions. ${ }^{3}$ The end of the Civil War fueled this preoccupation with blood identity and its limits, as white supremacist governments and communities fashioned laws, assembled vigilante groups, and established social practices that would codify race and "exclude African Americans and other people of

1 Frances E.W. Harper, "The Great Problem to Be Solved." A Brighter Coming Day: A Frances Ellen Watkins Harper Reader. Ed. Frances Smith Foster. New York: City University of New York, 1990. 222.

2 See, "Calvary's Stream is Flowing" (1891), "Cleansing Wave" (1871), "There is Power in the Blood" (1899), "Healing at the Fountain" (1885), "Saved By the Blood" (1875, Crosby), "Are You Washed in the Blood?" (1878), “Lord, Keep My Soul from Day to Day" (1899), and "Are You Washed in the Blood? (1878). There are also many other hymns, composed and sang in the late nineteenth-century, that employ blood imagery, including "Blessed Be the Fountain" (1881), "Come to Calvary's Holy Mountain" (1871), "Deeper Yet" (1896), "The Half Has Never Been Told" (1893), "It Cleanseth Me" (1899), "It is the Blood that Washes White" (1882), "Nothing But the Blood" (1876), "Saved Thru Jesus' Blood" (1899), and "Whiter than Snow" (1872). The imagery continued into the early decades of the twentieth century as well, with hymns such as "The Blood of Christ, the Spotless Lamb" (1901), "The Blood Will Never Lose its Power" (1912), "The Blood-Washed Throng" (1906), "Covered by the Blood" (1904), "His Blood Availed for Me" (1915), "I Have Found a Resting Place" (1918), "Saved By the Blood" (1902, Henderson), and "You Must Be Redeemed" (1902).

3 Ariela J. Gross, What Blood Won't Tell: A History of Race on Trial in America. Cambridge, Mass.: Harvard University, 2008. 5. 
color from public life."4 There were strict anti-miscegenation laws to restrict blood mixing, families barred non-white and mixed-race family members from inheritance, courts took on countless cases predicated on the criminal activity of a person with "negro blood," and Jim Crow laws summarily excluded African-Americans from white schools, white businesses, white communities, and white public spaces. By the latter days of the nineteenth century most white Christians believed Jesus's blood could symbolically cleanse and save, but "negro blood" could only corrupt and condemn.

It is fitting, then, that as an African American and Christian woman, Frances Ellen Watkins Harper would create a novel also focused on blood and its power over race and redemption. Indeed, Iola Leroy, or, Shadows Uplifted not only features a mulatta heroine, but references blood 68 times, including multiple stanzas of a nineteenth-century blood hymn titled “Drooping Souls No Longer Mourn” by Dr. Thomas Hastings. ${ }^{5}$ In a few cases, Harper's "blood discourse" alludes to the Civil War and the "blood of God's children" that was shed over slavery. ${ }^{6}$ At other times, blood is an animating feature, "stirring... with vigor," "rejoicing," or even "boil[ing]" through a person's veins. But most often, blood is used to demarcate a person's identity, rights, or status: "good blood," "Northern blood," "negro blood," "colored blood" "white blood," "mixed blood," "unmixed blood," "tainted blood," "outcast blood," "barbaric blood," "the best blood," "African blood," and of course, "the blood of Jesus." At once, Harper's discourse both reflects the century's quest to make race tangible — to fix racial categories in an effort to stratify society and assign rights—-while revealing that such categorization is

4 Ibid, 4-5.

5 According to John Julian, the hymn can be traced to 1831, when it appeared in a collection titled Spiritual Songs. Julian notes that it was "ascribed to Dr. Hastings, but without confirmation," yet argues that it is "in his style" and has "not been claimed by others" (495). See John Julian, A Dictionary of Hymnology, London: John Murray, 1892. 495.

6 Frances Harper, Iola Leroy, or, Shadows Uplifted. 1893. Mineola, N.Y.;Dover, 2010. 20. 
impossible, elusive, a myth.

But rather than dismissing the urge to codify, Harper offers her novel as a meditation on the process and performance of racial embodiment. What emerges is a "study of discursive systems" that is "intended to teach" and, as I argue, ultimately re-claims the non-white body as a site of power. ${ }^{7}$ In other words, all of that blood had to inhabit real bodies, and these corporeal markers of identity become texts that both conceal and reveal. While the marked body communicates a rich tale of oppression between those who, as Frederick Douglass describes them, are "within the circle," for those existing outside the experience of contested racial identity these texts are quite difficult to read (or may be read inaccurately) ${ }^{8}$ Iola Leroy, then, contains a diverse assembly of such texts: white bodies, black bodies, black bodies perceived as white, and mixed-race bodies for whom the categories of race are interchangeable and imprecise. This cast allows Harper to stage a dramatic tale of American race relations predicated on the nineteenth century's most pressing legal, political, and social question: how is race/ whiteness defined and made tangible? ${ }^{9}$

7 John Ernest, “From Mysteries to Histories: Cultural Pedagogies in Frances E. W. Harper's Iola Leroy.” American Literature 64.3 (Sept. 1992):497-518. 500.

8 Frederick Douglass, Narrative of the Life of Frederick Douglass. 1845. Mineola, N.Y.: Dover, 1995. In this early section of his narrative, Douglass provides an instructive example of reading slavery's "texts" by discussing the practice of slaves singing. According to Douglass, slaveowners and northerners would misinterpret slave songs as "evidence of their contentment and happiness" (9). Douglass explicitly condemns this as a misreading, stating, "It is impossible to conceive of a greater mistake. The song of a slave represents the sorrows of his heart; and he is relieved by them, only as an aching heart is relieved by its tears" (9). Here, slave songs, as texts, are read differently (correctly and incorrectly) by those inside and outside the slave system. Most poignantly, Douglass reflects, "I did not, when a slave, understand the deep meaning of those rude and apparently incoherent songs. I was myself within the circle; so that I neither saw nor heard as those without might see and hear" (8).

9 Here I combine race with whiteness because, for African Americans living in the post-Civil War South, discussions of "race" were always concerned with locating whiteness. As Charles W. Mills writes, categorizing race throughout history has been the process of labeling "whites" as "full persons," and of "categoriz[ing] the remaining subset of humans as 'nonwhite'... subpersons, so that they have a subordinate civil standing in the white or white-ruled polities." This "differential privileging of the whites as a group with respect to nonwhites as a group," allows for the "exploitation of their bodies, land, and resources, and the denial of equal socioeconomic opportunities to them" (11). Charles Mills, The Racial Contract. Ithaca: Cornell University, 1997. 
For non-white characters in the book, especially, the body becomes a palimpsest of racial policy, where rights and privileges depend on shifting categories and contradictions between blood line and visual markers of race. The novel tells the tale of Iola Leroy, who in her early years is unaware of the "cross in her blood" and lives as though she is white, the daughter of a well-to-do planter; but after her (white) father's death, Iola is "remanded to slavery" along with her black mother, and for the first time experiences the "the paralyzing power of caste." ${ }^{.10}$ Here, despite the "imperceptible infusion of negro blood in her veins," Iola's "negro" heritage becomes her primary identifier — the sole basis of her status before the law and society. ${ }^{11}$ Even more confusing is that, according to the perceptible markers of race, Iola evinces only her white heritage, having skin "just as white" as her fellow classmates at her northern boarding school. ${ }^{12}$ But with even one drop of "negro blood" Iola "must be colored, and she should be treated accordingly. ${ }^{" 13}$ The novel then traces Iola and her mixed-race brother Harry as they face the reality that they now inhabit a different symbolic space and stand disempowered before the law. As Anthony B. Pinn suggests, "The black body is shaped and defined through power dynamics. In a sense it is the cartography of power dynamics. The body, hence, is a story told to support the social system." ${ }^{14}$ In other words, in discussions of race, the body itself becomes a map that charts the non-linear course of American racial dynamics and a readable text that narrates the experience of individuals like Iola, Harper, and others who are caught in the unjust practice of racial categorization.

But Harper's tale of Iola Leroy is not what Zora Neale Hurston would later call a story of

10 Harper, Iola Leroy, 85, 89, and 79.

11 Ibid, 95.

12 Ibid, 85.

13 Ibid, 161.

14 Anthony B. Pinn, Embodiment and the New Shape of Black Theological Thought. New York: New York University, 2010. 4. 
"the tragically colored"15; instead, Harper appropriates the "shadowed" discourse of race and translates it into a source of light and power by rewriting marked bodies as sacred texts, which themselves narrate a distinct version of Christianity. Through the discourse of blood, explicitly, Harper reminds readers of "the blood of Jesus" that, through the Incarnation, provides redemption to all without discrimination. And as the novel progresses, Harper deepens her use of religious language and biblical allusion, ultimately concluding that, to pass "from the old oligarchy of slavery into the new commonwealth of freedom," black Americans must simultaneously embrace enlightenment and Christianity. ${ }^{16}$ But this is not just any Christianity; rather, Harper foregrounds the significance of "real, genuine religion" in her first few chapters, acquainting the reader with the Christianity of the slave community even before introducing Iola or the Leroy family. Here, it is identification with "Jesus the Nazarene" (a moniker that symbolizes rejection) that offers kinship through the experience of suffering and true, tested faith. In an easily overlooked passage, we learn of "a dear, old saint" named Aunt Kitty, who Robert Johnson, himself a slave, hails as "a living epistle.” As an allusion to II Corinthians, this metaphor connects Kitty to the early apostles and parallels her struggle under slavery with the trials of New Testament believers. As I will illustrate, this characterization is also a useful metaphor for Iola's own development in the novel and a useable exhortation that Harper communicates to the postbellum black community. For if the marked body can act as a text through its experiences of suffering and faith, and if it inherits a bloodline that marks them as descendants of the oppressed, then the black body itself can be a sacred referent, connected corporeally to the Incarnate Savior.

15 Hurston, Zora Neale. "How It Feels to Be Colored Me." I Love Myself When I Am Laughing. Ed. Alice Walker. New York: City University of New York, 1979. 153.

16 In the final scene of the novel, Harper insists that "the negro... enlightened and Christianized" will "sink the old animosities of slavery into the new community of interests arising from freedom" and "his influence up on the South will be as the influence of the sun upon the earth" (216). 
Ultimately, in Iola Leroy, or, Shadows Uplifted, Harper exploits the country's

preoccupation with bodily markers of race and blood discourse to point African Americans to the body and blood of Christ. Like the other progressive believers examined within this project, Harper insisted that it was the person of Jesus Christ who gave hope to the oppressed, as his humanity united believers with him in suffering. In this way, Iola Leroy testifies to the doctrine of the Incarnation and its implications for all Christians. But writing as an African-American woman in the latter decades of the nineteenth century, Harper projects her vision much further. In the novel, she extends her Unitarian theology into an early form of black liberal theology that was quite progressive for its time — deeming black Christians to be the "the black Nazareth" and considering their bodies as "living epistles" that testified to and bore the marks of the gospel. Because they were so closely aligned with Christ's suffering, Harper argued, black Americans could also hope to emerge from the "shadows" of racism into a "brighter coming day." And, most stunningly in the novel, it is a woman at the forefront of this liberatory movement. Through body and blood, then, Iola's life parallels that of Christ, and she chooses to identify with "the least of these" by sacrificing her position for the redemption of the black community. For these reasons, Harper's novel calls us to re-map the terrain of black liberal theology, to examine her practical iteration of Christianity that evolved from her membership in both Unitarian and A.M.E. churches, and to deepen our appreciation for Harper's own ministerial role as "a doer of the word." ${ }^{17}$ As one reviewer for the Christian Recorder noted in 1866, Harper was a writer and speaker who seized her public role as if "she had been ordained for this ministry—for the service

17 As I will detail later, I am indebted to Carla Peterson's work regarding black women writers, generally, and Frances Harper, specifically. She writes that Harper and others considered themselves "doers of the word" who "recognized the extent to which their efforts to 'elevate the race' and achieve 'racial uplift' lay not only in their engagement in specific political and social activities but also in their faith in the performative power of the word-both spoken and written" (3). See Carla L. Peterson, Doers of the Word: African-American Women Speakers and Writers in the North (1830-1880). New Brunswick: Rutgers, 1995. 
of the pulpit is not the only ministry that God had appointed."18

\section{Marked Bodies, Living Epistles}

In an 1893 poem titled "Simon's Countrymen," Frances Harper pays homage to Simon the Cyrenean who, according to the Synoptic Gospels, helped Jesus carry his cross on the way to Calvary. Careful to note his skin color Harper writes, "That helpful man came from the land / Kissed by the ardent sun." 19 A few stanzas later, Harper asks, "Can they who speak of Christ as King, / And glory in his name / Forget that Simon's countrymen / Still bear a cross of shame? / Can they forget the cruel scorn / Men shower on a race / Who treat the hues their Father gives / As emblems of disgrace?"20 The move is a somewhat familiar one for Harper, as a writer who often employed biblical typology in her poetry; but like many writers before her, Harper's allusions to the bible usually focused on the Old Testament. Her 1869 collection Moses: A Story of the Nile is the clearest example of this — a form of what Eddie Glaude Jr. calls "Exodus politics," by which African Americans "elevated their common experiences to biblical drama" and aligned themselves with the Israelites in their struggle to "create a free people and to live up to the moral principles that signify the best way of living." ${ }^{21}$ But when Harper published "Simon's Countrymen," she included with it four other New Testament-focused poems in a reprint of her Moses collection. The move was subtle, but significant. By melding the Old

18 Qtd. in Peterson, Doers of the Word, 132.

19 Biblical reference to Simon from Cyrene appear in Matthew 27:32, Mark 15:21, and Luke 23:26. Cyrene was an ancient Libyan city in North Africa, so most bible commentators agree that Simon was likely darkskinned or black. Commentators disagree, however, whether "Simon of Cyrene" was the same person as "Simeon called Niger" who is referenced in Acts 13:1 ("Niger" means black). See John F. Walvoord, Jr. and Roy B. Zuck, eds. The Bible Knowledge Commentary. Vol. 2. Colorado Springs: Dave Cook, 1983. 779.

20 Frances E. W. Harper, "Simon's Countrymen." A Brighter Coming Day: A Frances Ellen Watkins Harper Reader. Ed. Frances Smith Foster. New York: City University of New York, 1990. 333-334.

21 Eddie S. Glaude, Exodus! Religion, Race, and Nation in Early Nineteenth-Century Black America. Chicago: University of Chicago, 2000. 162. 
Testament Exodus account—so often referenced in slave narratives—with Christ's message of freedom in the gospels, Harper was able to transmute the black experience of exile and slavery into one of eternal victory and power. Further, Simon's presence in Harper's poetry provides a link between the Exodus and the Incarnation. In the words of Frances Smith Foster, "This time there is no mistaking the identification of African Americans as a new Israel. ${ }^{22}$

But for the purposes of this chapter, Harper's allusion to Simon is additionally instructive: it reveals her growing conviction that the marked, black body has a rightful place in sacred history and that the experience of black Americans symbolically parallel the story of Christ. Like Simon, African Americans participated in the suffering of Christ metaphorically, bearing a similar "cross of shame" in a nation that was only "Christian in name," as one character in Iola Leroy deems the United States. ${ }^{23}$ And so black skin color could actually be a referent to the Incarnation — a text written on by the "Father" himself, who "gives" blacks their "hues." 24 Indeed, in this same period of her career, Harper questioned, "Would not the vision of Christians grow clearer to see, beneath the darkened skin and shaded countenance... the human soul all written over with the handmarks of Divinity?" ${ }^{25}$ Similarly, in a poem titled "The Burdens of All" (1900) Harper unites "the black, the brown, and white" races under Christ's mandate to "ease the burdens of men" and "build the kingdom of God." ${ }^{26}$ In the concluding verse, Harper boldly argues, "The burdens will always be heavy, / The sunshine fade into night, / Til mercy and

22 Frances Smith Foster. A Brighter Coming Day: A Frances Ellen Watkins Harper Reader. Ed. Frances Smith Foster. New York: City University of New York, 1990. 326. The concept of the "new Israel" is most often taken from Galatians 6:16, where Paul connects Christians with the inheritance of the nation of Israel. In other words, as the Israelites were the chosen people of God, Christians of the modern era were "grafted in" and became heirs of the covenant under Christ.

23 Harper, "Simon's Countrymen," 334.

24 Ibid, 333.

25 Harper, "True and False Politeness," A Brighter Coming Day, 398.

26 Harper, "The Burdens of All," A Brighter Coming Day, 390. 
justice shall cement / The black, the brown, and the white."27

It would be easy for twenty-first century readers to miss the radicalism of Harper's commitment to interracial harmony in the late nineteenth century. Indeed, some scholars oversimplify her depictions of race (ironic, because Harper works to problematize such categories) or decry her fidelity to blackness (assuming, again, in twenty-first century terms, that she is being essentialist). For example, one scholar of Iola Leroy questions whether the novel is "entirely successful in its challenge to postbellum racism," citing that, at times, the narrative "dramatically demonstrates the arbitrariness of racial categories and the fluidity of racial identity," but that it ultimately "retains a commitment to race as an expression of bodily essence." 28 The writer goes on to say that the novel likely fails because it relies on "sentimental discourse to achieve its political objectives," which "put it at odds with its more radical potential. ${ }^{29}$ But such a reading misses, entirely, Harper's carefully-crafted explication of race in the late nineteenth century, while revealing a level of presentism that ignores the enormous racial barriers placed on individuals like Harper — a doubly-marked black woman, who was writing in an era of deep (legalized) racism and an era when women were denied basic political and social rights. $^{30}$

The reality is that Harper lived a courageous public life in slavery's aftermath, and with the failure of Reconstruction, Harper witnessed an unprecedented escalation in racial violence and legalized segregation. As early as 1867, some southern states had banned interracial

27 Ibid.

28 See Lori Robison, “An 'Imperceptible Infusion' of Blood: Iola Leroy, Racial Identity, and Sentimental Discourse." Genre 37 (Fall/Winter 2004): 433-460. 435

29 Ibid.

30 In her article "Further Liftings of the Veil: Gender, Class, and Labor in Frances E. W. Harper's Iola Leroy," Carla Peterson helpfully places Harper within the extraordinary layers of racial debate "preoccupying the black leadership during the Reconstruction period"-from African emigration and education, to labor issues and economic concerns facing blacks in the agrarian South and urban workers in the North. See "Further Liftings of the Veil: Gender, Class, and Labor in Frances E. W. Harper's Iola Leroy." Listening (1994):97-112 
marriage, Black Codes drew color lines between black and white bodies in public spaces, the Klan and vigilante groups attacked black men and women with legal impunity, the Supreme Court declared the 1875 Civil Rights Act unconstitutional, and "legal, state-sanctioned segregation triumphed in the 1890 s," culminating in the Plessy v. Ferguson decision. ${ }^{31}$ Harper saw this dramatic assault on black bodies firsthand, traveling throughout the South during Reconstruction. She lived in African-American communities, engaged in conversations with locals (black and white), and lectured at freedmen's schools, public halls, churches, and Sunday schools. Harper's letters reveal the scope of violence and suppression she and other lecturers faced in these endeavors. On one occasion she writes that "there had been some violence in the district" where she was to speak, but says, boldly, "I had promised, and, of course, I went." 32 In another encounter, Harper found herself surrounded by "a small congregation" on a train, while she talked with a former slave dealer. "We had a rather exciting time," Harper writes, noting, "I was traveling alone, but it is not worth while to show any signs of fear." 33 While lecturing with William Still in South Carolina in 1867 Harper wrote, "Next week, I am to speak in a place where one of our teachers was struck and a colored man shot, who, I believe, gave offense by some words spoke at a public meeting." But she concludes, "I do not feel any particular fear."34

31 While the Black Codes were dismantled by Congress in 1867, Smith reminds us that "Congress could not erase the cultural imperatives that gave rise to the Codes in the first place. Unspoken protocols of racial segregation prevailed during Reconstruction. It seemed to matter little who had political control in these years, for even with Republicans and black voters in control, schools were segregated and the races increasingly kept apart" (51). Additionally, while the Plessy v. Ferguson ruling did not come til 1896, many states had already passed laws mandating segregation between black- and white-skinned citizens, such as Louisiana, which passed a law in 1890 that segregated railroad cars (72-73). In the case of Plessy v. Ferguson, there was also a good deal of "blood" talk, which parallels Harper's own writings, but cannot be detailed (due to length) here. For more, see Smith, 72-76.

32 Harper qtd. in Melba Joyce Boyd, Discarded Legacy: Politics and Poetics in the Life of Frances E.W. Harper, 1825-1911. Detroit: Wayne State University, 1994. 123.

33 Harper qtd. in Boyd, 123.

34 Ibid, 124. Harper references the threat of violence throughout her letters, providing more examples than I can include here. In each case, her bravery evinces a spirit of defiance, such as when, at one lecture in Alabama, she encountered "some of the most noted rebels" and reflects, "If you had seen the rebs I had out last night perhaps 
Furthermore, during these tours in the South Harper's own "marked" body was attacked, symbolically, by audience members who accused her of being "a man" and "not colored [but] painted. ${ }^{, 35}$ In her letters, Harper also frequently references the great fatigue she experienced from her constant, unrelenting schedule, stating that her body is weary because her "work is wearing. ${ }^{36}$ In the end, Harper's actions were motivated by a belief that God had ordained her to "preach" to the "congregations" of the South and that this work on behalf of racial justice was sacred work — that "if any lover of Christ wants a field for civilizing work, here is a field." 37

It is in Iola Leroy, however, that Harper most vividly asserts the divine work of black bodies, symbolically depicting the Exodus through Iola's passage from slavery to freedom, South to North, and paralleling the power of the Incarnation through a vision of the liberatory "black Nazareth." But before proceeding with her vision, Harper first establishes the imprecision of race. By examining the practice of racial codification, Harper exposes the fraudulent notion that race can be detected through the senses - that one's blood ancestry is made visible through skin color, is audible through speech pattern, is tangible through touch, or is perceivable through any form of conduct. In this way, the novel is (rightly) as preoccupied with marked bodies and tainted blood as was the American society in the era of Segregation. Indeed, nineteenth-century discourse reflected a growing fear among whites that "blackness was in danger of becoming whiteness" because as "the number of visually ambiguous 'black' people increased (the great age of 'passing was 1880-1925)... sight became ever less reliable as an authenticator of racial identity." ${ }^{38}$ Iola, and many of Harper's cast of characters represent this "ambiguous" racial class,

you would have felt a little nervous for me. However, I lived through it, and gave them more gospel truth than perhaps some of them have heard for some time" (qtd. in Boyd 144).

35 Harper qtd. in Foster, 127.

36 Ibid, 140, 141, and 144.

37 Ibid, 142.

38 Mark M. Smith, How Race is Made: Slavery, Segregation, and the Senses. Chapel Hill: University of North 
and they posed a threat in post-slavery society, as "race had to be authenticated on a daily basis between strangers in a modernizing, geographically fluid South." ${ }^{39}$ Realizing that sensory indicators of race were unreliable, the white-supremacist South pursued new ways of assessing and codifying race. To understand this moment in America's racial past, Mark M. Smith's study is incredibly valuable, and according to his searing description: "The basis of informal and formal segregation was loathing, an almost unspeakable bitterness and stunned horror felt by Confederates who had lost a war at a terrific cost. Evidence of loss was permanent, insistent, forcing its way into all the sense of an angry white South, acidic hate puddling in its guts."40 Eventually, Jim Crow laws and the cultural practices of Segregation reimposed stability on the chaos of racial mixing and, to borrow Smith's phrase, "took the thinking out of life.",4

Into this space Harper introduces a troupe of characters with contested racial identities. Iola's mother, Marie, is black, but due to her beauty, fair skin, seminary education, and purity her husband says, "In the North, no one would suspect that she has one drop of negro blood in her veins." 42 Iola, who later finds out she is of mixed race (being the daughter of a white man and a black, manumitted slave woman) is visually "just as white” as her northern school friends. Iola's social status also "marks" her as white, because she occupies white social circles, attends an esteemed academy in the North, and generally conducts herself as the daughter of a southern slaveholder who defends the institution. ${ }^{43}$ Similarly Iola's mixed-race brother Harry grows up thinking of himself as white, "turns very pale" when he learns of his heritage, and knows

Carolina, 2006. 7.

39 Ibid.

40 Ibid, 56.

41 Ibid.

42 Harper, Iola Leroy, 59.

43 Ibid, 85 and 83. 
"nothing of colored people except as slaves." ${ }^{44}$ Later in the novel, Dr. Latimer is described as having a "blonde" complexion, with eyes "bright and piercing," "lips well moulded, his manner very affable, his intellect active and well stored with information"—a man (mistakenly) regarded by his colleague Dr. Latrobe as white. When Latimer's true identity is revealed, Latrobe's thoughts voice the wariness of post-Civil War white culture: "Dr. Latrobe had thought he was clear-sighted enough to detect the presence of negro blood when all physical traces had disappeared. [...] He could not help feeling a sense of vexation at the signal mistake he had made." 45 By depicting the "slipperiness of racial categories" in this way, Harper's characters expose as fraudulent the practice of segregation and the absurdity of race as a tangible, fixed category. $^{46}$

And yet, in the late nineteenth century and onward, Americans refused to abandon "race" as a bodily marker of difference; as a result, many African Americans, such as Harper's fictional characters, chose to adopt the marked body as a site of power. In the broader, white-supremacist U.S. culture, the terms of race were constantly being redefined and reconceptualized, but in the end black bodies always existed as the symbolic other, and mixed-race bodies were met with anxiety on the part of whites who could not neatly categorize them. States rushed to define what made a person "black," giving rise to the one-drop rule by which any connection to "negro" blood made a person legally black. ${ }^{47}$ In Iola Leroy, Alfred Lorraine (Eugene Leroy's cousin)

44 Ibid, 100 and 104.

45 Ibid, 185.

46 Ibid, 72. In his brief essay, Robert C. Nowatzki provides only a skim of Iola Leroy, but does include some helpful context regarding anti-miscegenation laws of the time. He writes that these laws were "particularly open to critique not only because [they] worked from untenable assumptions about race, but also because of [their] self-contradictory nature" (42). See Robert C. Nowatzki, "Miscegenation and the Rhetoric of Blood in Three Turn-of-the-Century African-American Novels." Journal of Contemporary Thought 6 (1996):41-50.

47 For a specific example of this legislation, Smith cites the shifting laws in Virginia, a state that "toyed with various fractions" of blood ancestry to establish its racial categories. Until 1910 "one quarter meant black; between 1910 and 1924 the fraction dropped to one-sixteenth; by the mid-1920s Virginia had gone to the onedrop rule" (75). But Virginia was not alone in its legislation of race. Instead, Smith notes that "all southern 
laments Marie Leroy's heritage, declaring, "One drop of negro blood in her veins curses all the rest. ${ }^{, 48}$ And it is Lorraine who sends a spy to verify Marie's ancestry after her husband's death, hoping to once again fix Marie (and her children) in their "proper" place, as black not white. Lorraine locates a neighbor from the past, who admits Iola called a "colored woman" Grandma and with that, "the story was sufficient" and Iola, with her brother, "must be colored." 49

But prior to Iola's inward transformation we meet Aunt Kizzy, who serves as a model for the marked, and therefore powerful, black body. In an easily overlooked passage in Chapter 6, Robert Johnson, a fair-skinned slave, is talking to a Union soldier and remarks he "never did take much stock in white folks' religion," but instead believes "in the real, genuine religion." ${ }^{50}$ As an exemplar of this true faith, he hails a "dear, old saint, named Aunt Kizzy," who as a slave had "seen hard times, but was what I call a living epistle." ${ }^{.1}$ Of course Johnson is arguing that real Christianity is lived out by his fellow slaves more faithfully than his "Christian" slaveowners, whose cruelty he describes in a prior passage. Much like Frederick Douglass distinguishes between "the Christianity of this Land" and the "Christianity of Christ," Johnson separates the fraudulent religion of his "ole Miss"-who was "as good as most of them. She said her prayers and went to church"- and the "genuine religion" of Aunt Kizzy. ${ }^{52}$

By deeming Aunt Kizzy a "living epistle" Harper is able to set up an important scaffold for the rest of the novel, so that the blood, flesh, and spirit of a black believer combine to produce a living sacred text. The phrase comes from Paul's second letter to the Corinthians, in which he tells new believers, "Ye are our epistle written in our hearts, known and read of all

states made mixed race marriages illegal and, in the process, described what made a black person 'black'" (75).

48 Harper, Iola Leroy, 60.

49 Ibid, 161.

50 Ibid, 45.

51 Ibid.

52 Douglass, 71; and Harper, Iola Leroy, 45. 
men: Forasmuch as ye are manifestly declared to be the epistle of Christ ministered by us, written not with ink, but with the Spirit of the living God; not in tables of stone, but in fleshy tables of the heart." ${ }^{, 53}$ In regard to enslaved Christians, the reference has two significant implications. First, Aunt Kizzy is a "living epistle" because her goodness and joy are illustrative of her faith in Jesus and her belief that "if I couldn't get justice here, I could get it in another world." ${ }^{, 54}$ And because Harper's novel is a "study of discursive systems," Harper reminds readers that slaves were legally barred from learning to read and write. ${ }^{55}$ Kizzy, as a bodily text, is likely the only "biblical” text many of her fellow slaves will ever "read." In fact, Harper juxtaposes Kizzy-as-text with other allusions to slaves learning to read, noting for example Tom Anderson's own quest for traditional literacy. Anderson is said to have risked his life to travel miles away, "carrying his library on his head" (in his hat) to "take [reading] lessons from a white gardener in Virginia." ${ }^{, 56}$ Also, when Iola becomes a school teacher, she realizes that her students who were technically illiterate had become skilled in learning from the living texts that surrounded them: "Ignorant of books, human faces were the scrolls from which they had been reading for ages." Here and elsewhere Harper proclaims reading as "the key to forbidden knowledge" and, in doing so, speaks to a perennial concern in many slave narratives and asserts a position she herself held - that education was the key to freedom and individual and communal uplift. ${ }^{58}$

Second, in describing Aunt Kizzy as a "living epistle" written upon "with the Spirit of the

53 See II Corinthians 3:2-3 (KJV). All biblical texts quoted here will be from the King James Version, the translation standard for the era and the version Harper herself quotes from in this novel and her other works.

54 Harper, Iola Leroy, 45.

55 Ernest, 500.

56 Harper, Iola Leroy, 43.

57 Ibid, 118.

58 Ibid. Throughout Harper's fiction, poetry, and correspondence she references the need for African Americans to be educated, stating, in one address that, "Society cannot afford to neglect the enlightenment of any class of its members" "We Are All Bound Up Together, 217). See also Harper's speeches "Coloured Women of America" and "The Great Problem to Be Solved," her article, "A Factor in Human Progress," and especially her letters from 1865-1875 during which time Harper made several trips to the South and wrote home of the great need for freed slaves to be educated. 
living God," Harper transforms the marked, black body into a site of power through spiritual victory. Indeed, it is this promise of a spiritual, heavenly victory that beckons Kizzy, who is said to sing of "one day" going "wid de angels" where she'll "walk dem golden streets, Hallelujah!,"59 Similarly, Robert says that John 14 was Kizzy's "favorite chapter" from the bible—a chapter that speaks of Christ preparing "many mansions" for believers in heaven. ${ }^{60}$ Kizzy-as-sacred-text, then, unites her—spiritually and corporeally—with a heritage of believers tracing their roots to the New Testament church and urges black Christians to "rest assured," as Harper once said, "that we all come from the living God and that He is the common Father." ${ }^{\text {"61 }}$ Or, in the words of one of Harper's contemporaries, the late-century Episcopalian minister Rev. Charles Briggs: "It was not the design of Jesus Christ that His one flock should be divided by racial difference." ${ }^{20}$ Most importantly for the novel, Kizzy's presence alludes to other black bodies as sacred referents and allows Harper to seize the era's blood discourse and racial categorization for redemptive ends.

Like Kizzy, Iola's body is also a text that is eventually transformed into a site of power. Upon siding with the black community Iola goes on to adopt the discourse of marked bodies and boldly declares, "The best blood in my veins is African blood, and I am not ashamed of it." this way, as I will illustrate, Harper chooses to appropriate this "one-drop" status and recast the black body as a site of power, as a sacred referent that embodied the Spirit of Christ. So, while the categories of race seek to "render the strange familiar so as to control it" and to "define exclusion and inclusion," Harper adopts the racial "other"-blackness—as a marker of the Most

59 Ibid, 45.

60 Ibid.

61 Harper qtd. in Foster, 220. The text is from a speech Harper gave during the Centennial Anniversary of the Pennsylvania Society for Promoting the Abolition of Slavery, held in Philadelphia on April 14, 1875. The speech is titled "The Great Problem to Be Solved" (219).

62 See Charles A. Briggs, "The One Flock of Christ.” Reformed Quarterly Review 3 (Jul 1896):302. 302.

63 Harper, Iola Leroy, 162. 
High. ${ }^{64}$ Her choice reflects what David Theo Goldberg aptly deems "discursive counteraction," in that she seeks to change a "constitutive feature" in the discourse by "assigning new meaning to some established term." ${ }^{65}$ By describing Kizzy as a "living epistle," a sacred text, Harper establishes a framework for the unfolding novel and a symbolic matrilineal heritage for Iola herself to follow. But before assessing Harper's vision for the black community, it is imperative to examine her own brand of Christian theology. Such an analysis has been regrettably absent from most scholarship on Iola Leroy; but Harper's progressive Unitarianism undergirds her view of the marked, sacred body and gives rise to her concept of the black Nazareth, which Iola embraces at the novel's close.

\section{Harper's Unitarian Christ}

In an 1899 column in the Friends Intelligencer the Unitarian minister Dr. Joseph May proclaimed: "Let us go back to the beginning [...] let us make religion practical and moral; let us make Jesus literally our pattern." ${ }^{, 66}$ Like the other Christians on the margins already discussed in this study, Rev. May had grown frustrated with the "whole community of nominally civilized Christians" in the United States - believers who lifted their voices to Jesus on Sunday mornings, but remained silent on the issue of racism and racial violence erupting throughout the country. ${ }^{67}$ For his part, May was reacting to a recent lynching in Georgia, where a man was "hack[ed] to pieces," then burned alive, while thousands (presumably many of them Christian) "flock[ed] to

64 See David Theo Goldberg, Racist Culture: Philosophy and the Politics of Meaning. Cambridge: Blackwell, 1993. 8.

65 Ibid, 10.

66 See Joseph May, “Address By Dr. Joseph May: Corruption in Our Politics.” Friends' Intelligencer 56.19 (13 May 1899):374. 374.

67 Ibid. 
the spectacle" hoping to gain a "disgusting relic" as a souvenir. ${ }^{68}$ In response May writes that he is "almost ready to despair" and condemns the "attitude and utterances — or silence — of [the] ministers." ${ }^{69}$ But May recovers, offering his exaltation of Jesus as a practical "pattern" for love and social justice, saying "our greatest error in the past has been that we have devoted too much the energies of our thought to the theological... and too little... to the side of philanthropic service. ${ }^{, 70}$ As the pastor of the First Unitarian Church in Philadelphia, May had inherited a discourse of Jesus from his predecessor, Rev. Dr. William Henry Furness, who ten years earlier similarly wrote, "'Behold the Man!' Why shall not our special symbol be Jesus of Nazareth?"71 Together, the two ministers extolled the humanity and the power of Christ, in answer to “manifold, appalling evils" of society, such as lynching, racist practices, white supremacist laws, and Christians who seemed ignorant of the injustice. And for 25 years they also served as Frances Harper's pastors and spiritual guides. ${ }^{72}$

Few scholars even remark upon the Unitarian influence of May and Furness on Harper's theological outlook; fewer still provide sustained discussions of how Harper's theology illuminates her literary contributions and her vision for the black community. There are notable exceptions, such Carla Peterson who, in Doers of the Word, briefly entertains Harper's early

68 Ibid.

69 Ibid.

70 Ibid. Once again this echoes the discussion of Horace Bushnell's liberal theology as noted in chapter 1 of this study. Bushnell reminds Christians to go into the neediest places in society through charitable sacrifice- $-\mathrm{a}$ major component of Christian Liberalism that laid the groundwork for the Social Gospel of the next century.

71 See William Henry Furness, “Jesus of Nazareth.” The Unitarian Review 32.1 (July 1889):47. 47. Furness's career spanned an impressive 50 years at the First Unitarian Church of Philadelphia, and he was a prolific writer, publishing many columns, essays, bible study guides, and his book-length A History of Jesus. In his writing, Furness argued vehemently for Christians to look to Jesus's humanity, to understand his suffering, and to advocate for fair treatment of black Americans, Jews, and those oppressed around the world. Similarly, in his "Address" May laments the war in the Philippines, stating it is an example of the "same contempt of an inferior race" that existed during slavery and has led to racial violence in the U.S. For more on the ministries of Furness and May, see "Our Legacy." First Unitarian Church of Philadelphia. 2014. Web.

72 Furness, 47. 
involvement with both congregations. ${ }^{73}$ Peterson writes that Harper "assiduously participated in activities of the A.M.E. church throughout her life," while "Evangelical Unitarianism enabled [her] to envision herself as a poet-preacher whose faith in the particular figure of Christ empowered her to promote social engagement in order to achieve the goal of universal harmony." 74 But Peterson's study reaches only to 1880 , so there is no analysis of Harper's theology through the lens of Iola Leroy and no discussion of how Harper's theology shifted and deepened later in life. Similarly, other scholars reference Harper's affiliations with A.M.E. schools in the South or her time at Union Seminary (run by the African Methodist Episcopal Church), but neglect any nuanced discussion of theology. ${ }^{75}$ As a result, Iola Leroy has not been adequately mapped alongside the terrain of late nineteenth-century progressive theology or charted against Harper's own movement toward black liberalism. Questions, therefore, persist: Why would Harper maintain a commitment to both denominations? Why would she, who grew up in the African Methodist Episcopal church and wrote extensively for its publications, including the widely-circulated journal the Christian Recorder, attend weekly services at a Unitarian church? And why would Harper, during the rise of the black church movement, and with family affiliations in A.M.E. congregations, choose to become a member at a predominately

73 Other notable scholars who do treat Harper's theology include Frances Smith Foster and Melba Joyce Boyd, both to whom I am much indebted, as they have collected a staggering amount of Harper's published and unpublished work. Both also give attention to Harper's faith and the ways in which it animated her political and social work.

74 Peterson, Doers of the Word, 124.

75 For discussion of Harper's work with A.M.E.-sponsored schools in the South, see Leslie W. Lewis, "Biracial Promise and the New South in Minnie's Sacrifice: A Protocol for Reading The Curse of Caste; or, The Slave Bride. African American Review 40.4 (2006):755-767. For analysis of Iola Leroy related to Harper's work in A.M.E. education, see Cassandra Jackson, "'I Will Gladly Share With Them My Richer Heritage': Schoolteachers in Frances E.W. Harper's Iola Leroy and Charles Chesnutt's Mandy Oxendine African American Review 37.4 (2003):553-568. And for a detailed analysis of Harper's extensive charity work and public service, see Terry D. Novak, "Frances Harper's Poverty Relief Mission in the African American Community." Our Sister's Keepers (2005):213-226. 
white church in Philadelphia in $1870 ?^{76}$

The answer to most of these questions lies in Harper's progressive Christology, through which she hails the humanity of Jesus and the immanence of God, while simultaneously highlighting the unique position of black believers in a society shadowed by racial injustice. And Harper's views are illustrative of late nineteenth-century Unitarian emphasis on the Person of Christ and the work of the Incarnation — views likely influenced by the teachings of Furness and May. By the time Harper joined First Unitarian in 1870, Furness had become well known in the region for his eloquence and his sermons on abolition. ${ }^{77}$ Furness preached his first anti-slavery sermon on July 4, 1839, and as it was quite the controversial topic at the time, even in the North, his message caused a stir in Philadelphia and within his own congregation. ${ }^{78}$ But Furness was unyielding, insisting that abolition was a "profoundly religious movement."79 Years later Furness gained national attention for his vociferous support of John Brown, with his name mentioned in national newspapers as the minister who accompanied John Brown's body through Philadelphia, on its way to New York. ${ }^{80}$

Harper, who read "the best magazines and ablest weeklies, as well as more elaborate work," would have been familiar with Furness's reputation as a Unitarian opponent of slavery and would have been likely to encounter his articles on Unitarian theology. ${ }^{81}$ And Harper

76 Harper became a member of the First Unitarian Church in 1870. See "Our Legacy." First Unitarian Church of Philadelphia. 2014. Web. For more on what Mark A. Noll calls "Black churches... coming into their own," see The Work We Have to Do: The History of Protestants in America. New York: Oxford University, 2000. 76-82.

77 Elizabeth May Geffen, Philadelphia Unitarianism, 1796-1861. Philadelphia: University of Pennsylvania, 1961. 196, 231.

78 Ibid, 190. Geffen also notes that, as a result of Furness's anti-slavery messages, a contingent in the congregation sought to have him removed as minister. But a majority supported him, and the effort to oust him failed (194).

79 Furness qtd. in Geffen, 207.

80 Geffen, 231. Additionally, according to First Unitarian Church, it is believed that Furness accompanied Brown's body through Philadelphia "under cover of darkness to avoid mobs seeking to desecrate the corpse" ("Our Legacy").

81 This remark about Harper comes from William Still, The Underground Railroad. Philadelphia: Porter and Coates, 1872. 797. Still and Harper toured the South together during Reconstruction, working to improve 
certainly aligned with his politics, being an ardent abolitionist and member of the Pennsylvania Abolition Society (as was Furness), and voicing public support for Brown after his raid on Harpers Ferry. ${ }^{82}$ Indeed, Harper's poetry references Brown "who made the gallows an altar high," and she wrote to him and his wife, following his conviction. ${ }^{83}$ In 1860 , Harper published an essay in tribute to Brown, titled, "The Triumph of Freedom-A Dream." ${ }^{\prime 84}$ As an allegory, the essay employs the prevalent blood discourse of the nineteenth century to situate Brown within the camp of the redeemed. Harper writes that the "aged man" (Brown) attempted to conquer the "blood-stained goddess" Slavery, but she killed him and "drained the blood from his veins." "85 Then Harper, like Furness, cast Brown's death as a rallying cry for the oppressed, writing, "It seemed as if his blood had been instilled into the veins of freemen and given them fresh vigor." ${ }^{\text {" }}$ The account closes by heralding this "new baptism of Liberty" and praising the sacrifice of "the old man and his brave companions. ${ }^{, 87}$ While it is impossible to know if Furness ever read this essay on Brown, it is quite likely that he would have read Harper's poetry, which was widelycirculated and even published in some of the same journals where his articles appeared. Additionally, an April 1875 account of a Pennsylvania Abolition Society locates Furness and Harper at the same meeting - the pastor and his then-congregant, together advocating for racial justice. On that day Furness recited the Lord's Prayer, amending the reference to "Thy kingdom" with the phrase, "the kingdom of Thy truth and justice," and Harper addressed the audience that

southern schools and draw attention to the extreme needs of freed black communities. Still also reviewed many of Harper's poetry collections and wrote the introduction for Iola Leroy. See Foster, for his reviews of Harper's works and for their correspondence.

82 See "The Pennsylvania Society for Promoting the Abolition of Slavery." Friends' Intelligencer 32.9 (24 April 1875):143. The account of the meeting names both "Wm. H. Furness" and Frances Harper as speakers that day.

83 Harper, "Then and Now" (Foster 371-374). And for Harper's letters see "To Mary Brown" and "To John Brown," both written in November of 1859, in Foster, 48-50.

84 Harper, "The Triumph of Freedom-A Dream," in Foster, 114-117.

85 Harper, "The Triumph," 116-117.

86 Ibid.

87 Ibid. 
was "equally divided between white and colored." 88

Like Furness, his successor Joseph May graduated from Harvard Divinity and made his reputation as a social reformer on behalf of African-Americans. May had inherited a legacy of liberalism and reform from his father, noted Boston Unitarian minster Samuel Joseph May, who dedicated his own career to emancipation, women's voting rights, and fair treatment of workers. The junior May, in turn, spent his years in the pastorate advocating for African-American education and against the violence and imperialism of the Filipino War. May was installed as minister of First Unitarian in 1876, and his writings overflow with a social Christianity that, he believed, was the only right response to an era of inequality and racial violence. Harper's personal letters hint at a close connection to May and his wife. In a 1903 letter to Francis Grimké, Harper writes that she would like additional copies of sermons he sent on lynching, so she might "have an opportunity to give at least one to Rev. Joseph May," who would likely be interested in distributing them to "larger audiences" and "women's clubs." 89 Indeed May was furious that so few Christians were responding to racial violence in the South-even worse, that they were participating in what he called "blood madness" - and lamented that "if the precepts of Jesus... had been our first and commanding law... we should not have been where we are now."90 In their interpretations of Christianity, then, both Furness and May stressed the social mandate of Christ's gospel and, as will be seen, they did so by focusing on Christ as the Word and Christ as the Incarnation. Harper, too, reflected this approach in her writing, translating what May called "the precepts of Jesus" into a modern-day Great Commission. ${ }^{91}$ In an 1870 letter to

88 "The Pennsylvania Society," 143.

89 Harper, "Count on Me as a Subscriber," qtd. in Foster, 322. Foster also notes that the letter is included in the Francis Grimké papers.

90 Joseph May “Address,” 374.

91 As I note in chapter 2, Charles Sheldon regarded Christianity as having a very similar mandate, and in The Redemption of Freetown he also uses the language of Commission to argue for white Christians to assist their 
William Still she remarked that, in their efforts at social uplift for African Americans, "whether we are hindered or helped, we should try to be true to the commission God has written upon our souls." 92 In Iola Leroy, Harper uses similar language, referencing what she calls the "divine commission" of racial uplift. ${ }^{93}$ I do not mean to imply that Harper merely derived her doctrinal outlook from Furness and May, as Harper was, herself, a mature student of theology. Rather, their theological congruity speaks to the ways in which, at some level, progressive Christians in the late nineteenth century were crossing racial boundaries - the very ones imposed on them by law - and gleaning truth from one another in order to address the senseless inequity and violence on their doorsteps. Furness and May were deeply committed to racial equality (and even more liberal than other Unitarians of the time) and Harper sat under their tutelage each Sunday, affirming her own claim that "We are all bound up together in one great bundle of humanity."94 Harper's poems and stories repackaged theological truths to reach and compel a wider audience, and for certain collections of poems, stories, and novels - Iola Leroy, for one-Harper sought out a black audience, specifically, to translate theology into action. Like her contemporary William Wells Brown, Harper believed that she should "influence others to higher associations" by giving her "principal encouragement to literature." 95 If God had chosen to send his Word to man, Brown wrote, then "every thought expressed, ennobling in its tendency and elevating to Christian dignity... God will reward." 96

black brothers and sisters in Christ.

92 Harper, "Here Is Ignorance to Be Instructed," qtd. in Foster, 125-126. The letter is also included in the William Still Papers.

93 Harper, Iola Leroy, 171.

94 Harper, "We Are All Bound up Together," 217. As I demonstrate in chapter 4, African-American writer, speaker, and minister Sutton E. Griggs also asserted that black Americans needed to "rally around the printed page." See Griggs, Life's Demands; or, According to Law. Memphis, TN: National Public Welfare League, 1916. 33.

95 William Wells Brown, "My Southern Home." 1880. From Fugitive Slave to Free Man: The Autobiographies of William Wells Brown. Columbia, MO: University of Missouri, 1993. 288.

96 Ibid, 289. 
For Harper, the "ennobling" thoughts of Unitarianism came through two specific teachings about Christ: Jesus as the Word of God and Jesus as the Incarnation. For the first, describing the Son of God as his Word had lasting implications for a people struggling to find a new narrative, a new story to tell itself about race and the dignity of humankind. One writer in the Unitarian Review expressed it this way: "The Word was in the beginning with God; but the Word was made flesh that we might see his glory. It needs to be made flesh continually in us, that that which was from the beginning may be declared. [...] Jesus is not here in the flesh; but the Word... ought to be here in our flesh." ${ }^{97}$ Believers were "co-incarnate with Christ," sharing in his message and taking it to the world. ${ }^{98}$ But the writer goes on to condemn the Church's tendency to follow "caste" and to "shut itself out from the great currents of the community's life," so that Christ's message was hidden from the world. ${ }^{99}$ The article ends by reminding fellow Unitarians "we are spirits in bodies" and that "the spirit without the body is impotent, being invisible and imperceptible." ${ }^{100}$ In other words, one's faith must also take on the flesh and be embodied in everyday, modern believers. In this way, the Word could work to transform the individual believer and indeed the whole Church, into a text to be read by the world. As noted earlier in this chapter, believers could become "living epistles" for their fellow man, and by casting Jesus as the ultimate Word, Christians followed in his footsteps, allowing their bodies (marked or otherwise) to refer back to and tell the story of their Savior who once "dwelt among" them. $^{101}$

Similarly, William Furness highlighted the connection between the Incarnate Christ and

97 “The Embodied Word.” The Unitarian Review and Religious Magazine 10.3 (Sept. 1878):334. 334. Emphasis added.

98 Ibid.

99 Ibid.

100 Ibid.

101 C.f. John 1:14, "And the Word was made flesh, and dwelt among us, (and we beheld his glory, the glory as of the only begotten of the Father,) full of grace and truth." 
God's dealings with man through text. In 1889 he wrote that "The character of Jesus" was "portrayed by no mortal hand" but rather by "God himself "who "wrote between the lines" and communicated to mankind through the "person of Christ."102 Consistent with other Unitarians in the nineteenth century, Furness goes on to praise Jesus's humanity, stating "It is in this perfection of his human nature that his divinity consists. [...] His true divineness can never be seen and felt so long as he is represented as a super-human, double-natured, anomalous being, having resources of life and power that we can never have." ${ }^{\prime 103}$ Furness was convinced that Christians did have access to life and power, in a way that would speak to "the manifold, appalling evils that still afflict our race"; but this power came through Jesus the man. ${ }^{104}$ Just as May had insisted on making Jesus "literally our pattern," Furness asked, "Why shall not our special symbol be Jesus of Nazareth — not as the second person of a divine Trinity, not as an Atoning Sacrifice, not as a superhuman being, but as a man, in whom, I repeat, the divine possibilities of our nature have been realized as never before nor since?"105 This Jesus of Nazareth would supply the "Life and Power of God" to believers, so they may "become like him" and share in his "heavenly Vision."

For Joseph May, Christ Incarnate was also the culmination of "written words [and]

102 William Henry Furness. “Jesus of Nazareth.” The Unitarian Review 32.1 (July 1889):47. 47.

103 Ibid.

104 Ibid. It was not that Furness and other Unitarians denied the divinity of Christ, but they chose to focus on his humanity as a way for believers to relate to (and be drawn to) the Savior. In chapter 1 I describe how Horace Bushnell and other leading Unitarians highlighted the humanity of Christ while also asserting the divinity of humankind, as men and women were made in the image of God. Similarly, about Furness, one writer for the Outlook said that, while Furness "is generally classed with the humanitarian wing of the Unitarian denomination... his humanitarianism is due, not to his denial of the divinity of Christ but his affirmation of the divinity in man" ("The Rev. William Henry Furness" 51). See "The Rev. William Henry Furness." Outlook 51.2 (12 Jan. 1895):51.

105 Ibid.

106 Ibid. Furness does use the phrase "life and power of God" twice in the essay. In its first use, "life" and "power" are not capitalized, but in the second reference both words are capitalized, as I've reproduced here. 
parchment scrolls" of ancient prophecies: the Word — the Unknowable made into flesh. ${ }^{107} \mathrm{He}$ writes that, while the bible provides "compositions wonderful, indeed... as the crude beginnings of a history and theology" they are still "pitiable as the report of actual intercourse between God and man."108 The most vivid and visible communication from God is through his Son, the one hailed as the Word made flesh. And still, because Unitarians prized the "word in its many forms," May circles back to the sacred text of scripture and asks of these books, "Can they reveal God?" ${ }^{109}$ His answer is resounding: "Yes, over and over-for he shall be there, there no matter how the childlike age interprets him. [...] And being there, if we go to find him, he shall come forth... to still us with the majesty and sweetness of his presence." ${ }^{110}$ With Jesus heralded as the Incarnate Word, surely believers should expect God to communicate to them through a variety of texts - scripture, nature, the "living epistles" of their fellow believers, and even literature, which could develop character and "forge social bonds" that would lead the reader to work for social and spiritual improvement. ${ }^{111}$

Aside from her poetry and fiction, Harper's clearest interpretation of the doctrine of the Incarnation came in a speech to the Brooklyn Literary Society in 1892:

We read that Christ left us as an example that we should tread in His footsteps; but does not the majority of the Christian world hold it as a sacred creed that the first print of His

107 May, “Address,” 374.

108 Ibid.

109 Peterson, Doers of the Word, 125. Peterson writes that "Unitarians looked to the spoken word in its many forms - preaching, prayer, hymn singing - as an important spoken instrument for evoking those emotions that would elevate moral conscience and bring about social transformation" (125); and May, "Address," 374.

110 Ibid and Peterson, Doers of the Word, 125.

111 Peterson, Doers of the Word, 125. Peterson talks briefly about Harper's writing in the context of "Unitarian literary theory" in the antebellum age. Unitarians believed that "religion should touch the heart," but that "faith must also be rationalized, assented to on the basis of intellectual reasoning." As a result, "rather than encourage the free flow of emotion, Unitarians argued that individual 'character' must be attended to in order to create moral beings whose duty it would be to work for social cohesion in a disordered world." Books, magazines, lectures, and voluntary associations all become instrumental in fashioning correct character-something in which Harper took part with her role as "poet-preacher" of the antebellum era. (125) 
feet in the flesh began in the days of his antenatal life; and is not the same spirit in the world now which was there when our Lord made His advent among us, bone of our bone and flesh of our flesh; and do we not need the incarnation of God's love and light in our hearts as much now as it was ever needed in any preceding generation? ${ }^{112}$

Like Furness, Harper affirms the "life and power" accessible through Christ's spirit, but she also is careful to mention the very real and tangible corporeal connection between Jesus and his followers - that he was made of bone and flesh, the very image of believers who follow "in His footsteps." Harper's “Jesus-as-example” is May's "Jesus-as-literal-pattern” and Furness's "Jesusas-special-symbol," as each return to God's purest expression of "love and light" to find a power capable of conquering the darkness around them. For Harper, this concept of the Unitarian Christ would motivate her to espouse a more liberal and decidedly black theology where the body not only reflected Jesus as the Word made flesh, but also, as a marked body whose text testified to Christ's suffering. But most importantly, the social implications of these theological tenets would motivate Harper to write her most celebrated work, Iola Leroy, in 1893. It is in the novel that her Unitarian theology meets with her lifelong commitment to African-American communities and where the Word not only becomes flesh, but black flesh.

\section{To Cast One's Lot With the Despised}

It is in Iola Leroy that Harper most clearly speaks to the dual identity of black believers and amends her otherwise Unitarian concept of Christ by insisting that, for black believers, Jesus was not just a "literal pattern" but also a fellow sufferer — an outsider from Nazareth who had cast his lot among the lowly and was despised and rejected by those in power. In other words,

112 Frances E.W. Harper, "Enlightened Motherhood." 1892. A Brighter Coming Day: A Frances Ellen Watkins Harper Reader. Ed. Frances Smith Foster. New York: City University of New York, 1990. 
Harper always and everywhere had to "traverse dual identities, one as [a] Christian, and the other as [a] descendent of Ham." ${ }^{\text {113 }}$ According to A. Nevell Owens, this duality—-this seeming contradiction, even —of being both chosen by God and an outsider set apart from the faithful, was one of the central theological concerns of A.M.E. congregants. ${ }^{114}$ And so, while it is difficult to assess the theological impact of the African Method Episcopal Church on Harper's theology, the denomination's focus on duality likely impacted her personal approach to the faith. Harper did not belong to a specific A.M.E. congregation in her adult life, nor did she significantly address denominational differences or doctrinal nuance. But Harper's primary discursive site for instruction was what Frances Smith Foster has aptly deemed the "Afro-Protestant press," and both Foster and Carla Peterson have written at length about Harper's hybrid fiction that incorporates the "African-American perspective" with "tutelary activity." 115 And just as A.M.E. believers asserted that their faith was indelibly marked by being descendants of Africa, by having marked bodies, and by being an unfavored race, so too did Harper incorporate these components of African-American theology into her writings. To do otherwise would almost be unthinkable because, while the entire United States lived in the shadow of slavery, black believers faced the reality of segregated churches (the reason the A.M.E. church was formed) and racist theologies. As a result, their view of Christ and the mission of His church was forever altered.

113 A. Nevell Owens, Formation of the African Methodist Episcopal Church in the Nineteenth Century. New York: Palgrave, 2014. xii.

114 Ibid, xii-xiii. Due to space, I regret that I am not able to provide a faithful depiction of Owens's useful history, as there are few such comprehensive examinations of the A.M.E. church and its evangelical, theological roots (including the history of the A.M.E. congregations in Philadelphia, where Harper lived). Of particular interest is Owen's chapter, "It Is Salvation We Want: The Path to Spiritual Redemption and Social Uplift."

115 See Foster, "Gender, Genre," 52; and Peterson, "Frances Harper, Charlotte Forten, and African-American Literary Reconstruction," 40-43. Frances Smith Foster, "Gender, Genre and Vulgar Secularism: The Case of Frances Ellen Watkins Harper and the AME Press." Recovered Writers/Recovered Texts. Ed. Dolan Hubbard. Knoxville, TN:University of Tennessee, 1997. 46-59.; and Carla L. Peterson, "Frances Harper, Charlotte Forten, and African-American Literary Reconstruction." Challenging Boundaries: Gender and Periodization. Eds. Joyce W. Warren and Margaret Dickie. Athens, GA:University of Georgia, 2000. 39-61. 
It is in Iola Leroy that we most clearly witness Harper traversing this dual identity. And while, as we have seen, her Christian doctrine clearly aligned with progressive Unitarianism in general, it was the imprint of race — of racial discourse, of blood discourse, of the concerns unique to the descendents of Ham - that produced a distinctly black theology in the text. Here, the marked bodies of African-American believers are not only transformed into "living epistles," but they also act as a sacred referent back to Christ, the Incarnate Sufferer whose bone and flesh unites black believers with his victory over sin and oppression. When Iola asks, "Is there a path which we have trodden in this country... into which Jesus Christ has not put His feet and left it luminous with the light of His steps?" the inquiry could have come from a white Unitarian referencing Christ's ministry on earth. ${ }^{116}$ But Iola is black, with "outcast blood in her veins," and this subjectivity, Harper reminds us, reframes the question: Is there an experience of oppression or suffering that black believers have endured, which the Person of Christ did not also endure? ${ }^{117}$ Here, Iola's status as a black Christian engenders a deeper relationship with Jesus the Man, one that white believers are not necessarily in a position to understand. ${ }^{118}$ Black bodies, Harper suggests, experientially come closer to Jesus through what the apostle Paul calls "the fellowship of suffering"- a closeness that also grants them participation in the "power of His resurrection." 119

In the novel. when mixed-race characters choose to "cast [their] lot with the despised," Harper signals an alignment between black believers and the Incarnate Christ. In fact, Harper's use of the term "despised" builds to a "rallying cry" in the novel, as the term appears five times in reference to the "hated negro," and then, finally, connects blacks explicitly to Christ in

116 Harper, Iola Leroy, 198.

117 Ibid, 163

118 Ibid.

119 Philippians 3:10-11. 
Chapter $30 .{ }^{120}$ More specifically, Harper uses two moments in the novel to portray Harry and Iola as Christ figures themselves, indicating that to be despised is to be chosen of and closer to God. The first comes soon after Harry and Iola learn of their mixed race heritage, when Harry makes the dramatic decision to sign up with a black regiment during the Civil War's final days. While he is "fair enough to pass unchallenged among the fairest in the land," he bravely tells the enlisting officer, "I am a colored man." ${ }^{121}$ Prior to this, Harper narrates Harry's process of grappling with his shifting racial status, as he is forced to confront his white supremacist culture head-on, for the first time in his life, and discovers he "knew nothing of colored people except as slaves." ${ }^{.122}$ Most importantly, Harry realizes that identifying as black would demand a great sacrifice, "turning his back upon every gilded hope and dazzling opportunity" he was afforded as a white man in nineteenth-century society. ${ }^{123}$ Ultimately, Harry sacrifices this privilege and identifies with what society saw as the "lowly," and Harper writes that this "test of his life" required him to acknowledge the profound "difference between looking on a man as an object of pity and protecting him as such, and being identified with him and forced to share his lot." ${ }^{124}$ In the end, "love was stronger than pride," and Harry identifies with other blacks in the flesh and, in doing so, also takes on their status, willingly, out of love. ${ }^{125}$

Harper is careful to indicate that Harry's sacrifice is an example of Christ's humility in the act of the Incarnation, and in this instance the black body—-marked and despised— becomes symbolic of the ultimate act of Love. This condescension, in other words, parallels Paul's own

120 In Chapter 30 Harper includes a poem titled "Rallying Cry," which comes during Iola's discussion at the "conversazione" where she speaks about Christ as "despised and rejected of men" $(195,198)$; and when Harry joins the "colored" regiment, he says he is siding with the "despised and hated negro" (105).

121 Harper, Iola Leroy, 104 and 105.

122 Ibid.

123 Ibid, 105.

124 Ibid, 104 (emphasis added).

125 Ibid. 
description of Jesus who "existed in the form of God [but] did not regard equality with God a thing to be grasped, but emptied Himself, taking the form of a bond-servant, and being made in the likeness of men." ${ }^{126}$ By taking on the tainted and corrupt "likeness of men" Christ identified with humankind, experiencing the suffering and travails of life on earth as one who is in the flesh—even as one with a marked body, as we shall see. For Christ to "share the lot" with the sinful human race, Paul writes he "humbled himself," condescending from on high and "sharing in flesh and blood."127 Finally, by writing that Harry has "cast[s] his lot" with the "despised," Harper summons a reference to the prophesied Messiah from Isaiah 53, who is "despised and forsaken of men, A man of sorrows and acquainted with grief." ${ }^{\prime 28}$ To be one of the despised, then, indicates that Harry is following more closely in the footsteps of Christ, taking on the tainted flesh and blood of an outcast race. This act also aligns Harry, finally, with the suffering and theology of fellow blacks, whose plight he could not understand as a white man. The "test of his life," then, leads Harry to discover what Aunt Kizzy lived and Uncle Daniel knew so long ago - that all the theology one needs is "at de foot ob de cross."129

In another scene, late in the novel, Harper's implied connection between the "despised" African-American race and the person of Jesus becomes explicit. The moment comes during the conversazione at Mr. Stillman's house, when Iola asks, "Is there a path which we have trodden in this country... into which Jesus Christ has not put His feet and left it luminous with the light of

126 Philippians 2:6-7.

127 Philippians 2:8 and Hebrews 2:14.

128 Harper, Iola Leroy, 105, and Isaiah 53:3.

129 Harper, Iola Leroy, 104 and 134. I regret that space does not allow for a fuller discussion of Uncle Daniel, as his character speaks to Harper's depiction of white Christianity and true religion. As Ernest writes, "As Aunt Linda, Uncle Daniel, Marie Leroy, and many others in the novel realize, there is a vast difference between institutional Christianity, which has been corrupted by the institution of slavery, and experiential Christianity" (507). This true Christianity is something Ernest goes on to describe as "the Christianity that fills the culture and spiritual space cleared by [the] rejection" of white religion, and here he cites Uncle Daniel who "larn'd my 'ology at de foot ob de cross" (508). 
His steps? ... Have we been despised and trodden under foot? Christ was despised and rejected of men." ${ }^{, 130}$ Here Harper is most clear about addressing her black readership, noting that, as "despised" people they share in Christ's suffering—not just Harry in particular, but the black race as a whole. Once again Harper echos Isaiah 53's Messianic prophesy; but in the context of the conversazione, where Iola proclaims her "hope for the future" and insists that the "pain and suffering" African Americans endure is really "the crucibles out of which come gold more fine than the pavements of heaven," the term "despised" has a larger context. It includes African Americans in a community of believers, from the New Testament church onward, who have suffered great injustice as believers of Christ in a sinful world. And these believers will be victorious over their suffering, just as Christ himself was victorious over death and $\sin .{ }^{131}$ Harper's rhetorical use of "despised," then, harkens back to Paul's first letter to the Corinthians, where the apostle exhorts oppressed believers: "God has chosen the weak things of the world to shame the things which are strong, and the base things of the world and the despised God has chosen." ${ }^{132}$ In other words, black Christians are "grafted in" to God's chosen people, sharing in the inheritance of all believers and included in the great "cloud of witnesses" who are redeemed as the "new Israel." 133

To further connect African-American believers to the suffering of Christ, Harper also incorporates other subtle yet significant rhetorical choices in Iola Leroy. One particularly striking

130 Harper, Iola Leroy, 198, with a cross-reference to Isaiah 53:3.

131 In a bit of foreshadowing, Harper wrote in an 1857 article, "There is hope; yes, blessed be God! For our downtrodden and despised race... that ere long we may present to the admiring gaze of those who wish us well, a people to whom knowledge has given power, and righteousness exaltation?" ("The Colored People of America," qtd. in Foster 100).

132 I Corinthians 1:27-28.

133 In an 1888 speech to the WCTU, Harper referred to the "cloud of witnesses" who share in Christ's suffering ("The Woman's Christian Temperance Union" in Foster, 285). This phrase is an allusion to Hebrews 12:1, which states, "Wherefore seeing we also are compassed about with so great a cloud of witnesses, let us lay aside every weight, and the sin which doth so easily beset us, and let us run with patience the race that is set before us." 
example is her use of the terms "cast" and "caste." First, Harper uses the verb "to cast" as an echo of Jesus's decision to "cast" his lot with sinners, condescending from his position on high to be with the lowly of this world. ${ }^{134}$ The phrase is used six times in the novel, each in relation to a mixed-race character's decision to identify as black: As the Civil War rages, Iola declares to her would-be-suitor Dr. Gresham, "I intend... to cast my lot with the freed people as a helper, teacher and friend. I have passed through a fiery ordeal, but this ministry of suffering will not be in vain." 135 Similarly, Harry tells the army officer he will "cast his lot with the despised and hated negro," and later in the same chapter we learn that, in a decisive battle of the war, "lots were cast" to determine which soldiers will go into the conflict; similar to the account of Jonahanother man chosen of God to perform a difficult mission-Harry is the "one on whom the lot fell."136 Later, Robert Johnson praises Harry, saying, "He has cast his lot with us," Dr. Gresham says Dr. Latimer "has cast his lot with them" (meaning the "negro race"), and Latimer remarks that while Iola has chosen to identify as black she "could have cast her lot with the favored race." ${ }^{137}$ Here, the concept of casting lots refers to the biblical practice mentioned seventy times in the Old Testament and seven in the New Testament - a practice similar to drawing straws, but a process in which participants believed God would insert his will into a given situation or

134 While not necessarily essential to this discussion, I would like to here acknowledge Peterson's use of the term "lowly" and its role in my own characterization of Harper's social mission. In her essay "Further Liftings of the Veil: Gender, Class, and Labor in Frances E. W. Harper's Iola Leroy,” Peterson discusses Harper's concern with class breakdown in black communities and examines the ways in which "the 'lowly' figure" into her speeches and letters. Peterson writes, "For Harper the question became whether fiction could perhaps serve as an enabling form that would promote the emergene of a black subultern subjectivity and allow this subaltern finally to speak" (104). See Carla L. Peterson, "Further Liftings of the Veil: Gender, Class, and Labor in Frances E. W. Harper's Iola Leroy." Listening (1994):97-112.

135 Harper, Iola Leroy, 95.

136 Ibid, 105. In the story of Jonah, when the storm arose and the sailors grew suspicious of its origin, they cast lots to see who may have provoked the unnaturally strong storm. In Jonah 1:7 we read, "they cast lots and the lot fell on Jonah." By equating Harry with Jonah, Harper is of course indicating Harry's "chosenness" for higher purposes.

137 Ibid, 170, 185, and 204. 
dilemma. ${ }^{138}$ Harry and Iola "cast their lots" with the black race, and in doing so, become "part of the Divine plan," indicating that the hand of Providence was at work in their lives even in these instances. ${ }^{139}$ And last, the rhetorical use of "casting lots" provides a connection to the Messiah himself, alluding to prophesies such as the one found in Psalms, which states, "They divide my garments among them, And for my clothing they cast lots." ${ }^{140}$

Finally, Harper juxtaposes her use of the verb "cast" with her extensive discussions of the noun "caste," referring to the rigid social divisions that persisted along racial lines after the Civil War. She condemns the "paralyzing power of caste," "spirit of caste," "caste prejudice," and even "the paganism of caste." ${ }^{141}$ Such an ungodly system, Eugene Leroy laments, is predicated on both "law and custom," separating slave from free, black from white, the powerless from the powerful. ${ }^{142}$ This stands in stark contrast to the Savior who would "cast his lot with the despised" and who was predicted in Isaiah to "proclaim liberty to the captives, and the opening of the prison to those who are bound." ${ }^{, 143}$ In other words, Harper sets up a clear distinction between "the paganism of caste" and the mandate for believers to "cast their lots" with the lowly. In an 1888 article, Harper phrases it this way: that the South must transition from "the spirit of caste to the spirit of Christ," which is a phrase Iola herself states when speaking to Uncle Daniel in Chapter 19 of the novel. ${ }^{144}$ At one point, Harper even unites the terms "cast" and "caste" in a question Robert poses to Harry: "Were you aware of the virulence of caste prejudice and the disabilities

138 Conversely, the Roman soldiers mocked this idea by casting lots for Jesus's garments after his crucifixion in Matthew 27:35.

139 Harper, Iola Leroy, 198. While Iola is not the one who uses the phrase "part of the Divine plan," Lucille Delany speaks the words over the entire black race.

140 See Psalms 22:18 and also Isaiah 53:3.

141 Harper, Iola Leroy, 79, 103, 158, and 201. There are others as well which use similar phrasing.

142 Ibid, 69.

143 Isaiah 61:1-2.

144 Harper, "The Woman's Christian Temperance Union and the Colored Woman," qtd. in Foster, 284; and Harper, Iola Leroy, 134. 
which surround the colored people when you cast your lot with them?"145 For Harry and Iola (and any mixed-race American), choosing to "cast one's lot" with the lowly also meant to wade into the turbulent and uncertain waters of "caste" - to be identified as the enemy like Jonah and to be despised like Christ himself. ${ }^{146}$ Further, the notion that anyone would even have a choice about their race destabilized the late nineteenth-century racial landscape, where white Americans preferred that race be "clearly defined and immediately recognized." ${ }^{\prime 47}$ Harper's cast/e discussion, then, reveals the absurdity of racial categories - how could one possibly "cast lots" to decide what race to be? - while pointing to the ways in which African Americans always and already existed within the confines of the caste system. Even if Iola and Harry wanted to pass as white, they were surrounded by a culture that insisted "separation was the key to whiteness.", And such separation was impossible when the "infusion" of identity was in their veins.

Once again, identity circles back to the discourse of blood and marked bodies. In all of these ways Harper rhetorically signals that her mixed-race characters follow in the steps of Jesus, who could have maintained his position in the heavens but chose to come to earth and identify with the lowly, the weak, the despised, the marked. On a deeper level, Harper signifies on the meaning of "blood ancestry" to unite racial embodiment with spiritual embodiment. It is as believers that African Americans are unified with Christ through his atoning blood; and it is as fellow sufferers of a despised race that African Americans are unified with Christ through the "outcast blood" in their veins. With this ever-present dual identity, Harper extended her vision for the black community beyond (white) Unitarian theology or mainstream Christological

145 Ibid, 158.

146 The term "cast" does have explicit links to the biblical account of Jonah. In Jonah 1:7 it reads, "Each man said to his mate, "Come, let us cast lots so we may learn on whose account this calamity has struck us." So they cast lots and the lot fell on Jonah." As the one held responsible for the storm, Jonah is then thrown overboard.

147 Gross, 78.

148 Ibid. 
doctrine. To understand her remarkable exhortation to her fellow members of the "black Nazareth," then, it is essential to examine carefully the climax of Iola Leroy: the conversazione of black leaders. Here, Iola's role in the black community expresses Harper's black, even womanist take on Unitarian Christology, and she ultimately insists that racial uplift must start with a practical Christianity built on a theology of the oppressed.

\section{Fashioning the Black Nazareth}

In the final pages of Iola Leroy, Iola laments that she would like to "do something of lasting service to the race," to which Dr. Latimer replies: "write a good, strong book" to "inspire [black] men and women with a deeper sense of justice and humanity."149 But Iola counters, "Who believes any good can come out of the black Nazareth?" ${ }^{150}$ Her phrasing alludes to a passage in the gospel of John, which tells of Jesus first calling together his disciples. After Philip is called by Jesus to join the ministry, he goes to tell Nathanael, "We have found him, of whom Moses in the law, and the prophets, did write, Jesus of Nazareth, the son of Joseph.” But Nathanael replies with skepticism: "Can any good thing come out of Nazareth?"151 A bit of biblical history is helpful here, as Jesus's status as a Nazarene effectively marks him as an undesirable, an outcast. In fact, one bible commentary from the mid-nineteenth century notes that, "There rested upon Nazareth a special disgrace, in addition to the general contempt in which the whole of Galilee stood," and, furthermore, while the term "Nazarene" was often used as an epithet, applied to Christ, it was also used to refer to early Christians "as a contemptuous

149 Harper, Iola Leroy, 203.

150 Ibid.

151 John 1:45-46. 
designation and a term of reproach." ${ }^{\text {.152 }}$ And while Jesus was called "a Nazarene" early in his life, that designation later changed to "Jesus the Nazarene," symbolizing that the term which once served as a geographical marker had now become an designation of disgrace. Nathanael's incredulous response to Philip expresses his disbelief that the long-anticipated and muchheralded Messiah would originate from such a place as Nazareth - that the one who would be crowned King of the Jews would come from such degradation. Or, as another contemporary commentator vividly expressed it: the term Nazarene "was the opprobrious symbol of his [Jesus's] obscure, original, and rustic training - the scornful stigma fastened on him in priestly conclaves - the ready sarcasm flung at him by the rabble of the capital — it was the superscription of the cross."

Indeed, Jesus's status as "Nazarene" had significant implications for African-American Christians who felt equally outcast and marked by their bloodline and heritage. Harper includes the reference to the gospel of John in her novel because she felt assured that black Christians shared in both the blood of Christ and the blood of contempt. They were "living epistles" whose lives referred back to Jesus's own life of suffering on earth, and their status as despised modernday Nazarenes connected them to the Incarnation. By invoking this passage from John's gospel, then, Iola's question — "Who believes any good can come out of the black Nazareth? — is meant to glance both backward and forward, identifying black believers with Jesus's status and establishing a distinctly black theological perspective on the Christian faith that is the culmination of the book's message.

Of course, Dr. Latimer's encouragement that Iola "write a good, strong book" is also

152 James Austin Bastow, A Bible Dictionary: Being a Contemporary Digest of the History and Antiquities of the Hebrews and Neighboring Nations. London: Longman Brown, 1859. 489.

153 Andrew Cameron, "The Return to Nazareth." The Family Treasury of Sunday Reading. London: Thomas Nelson \& Sons, 1860. 354. 
metacommentary on the uses and service of Harper's own novel and points us to the originally intended audience. In the Introduction to Iola Leroy, William Still remarks, "Doubtless the thousands of colored Sunday-schools in the South, in casting about for an interesting, moral story-book, full of practical lessons, will not be content to be without 'IOLA LEROY, OR SHADOWS UPLIFTED."'"154 Then, to bookend the story with directives, Harper writes a "Note" at the novel's conclusion, stating that the tale's "mission will not be in vain if it awaken in the hearts of our countrymen a stronger sense of justice and a more Christlike humanity." Most importantly, she hoped it would "inspire the children of those upon whose brows God has poured the chrism of that new era to determine that they will embrace every opportunity, develop every faculty, and use every power God has given them to rise in the scale of character and condition, and to add their quota of good citizenship to the best welfare of the nation." ${ }^{\text {"155 }}$ Harper's ideal audience, then, is the African-American community in general, and young black Christians, more specifically. As she remarked in a spirited article to black readers in an 1885 edition of African Methodist Episcopal Review: "What a field of usefulness lies before the educated young men and women of our race! What possibilities are in their hands!"156

Without a doubt, then, Harper's novel issues a sacred commission for the "black Nazareth" living in this "new era," and it is during the conversazione at Mr. Stillman's that Harper lays her vision bare. Here Iola convenes in a salon-type discussion with other "thinkers

154 William Still, "Introduction.” Iola Leroy, or, Shadows Uplifted. 1893. Mineola, N.Y.: Dover, 2010. 9. Capitalization is retained from the original text. Like Charles Sheldon's sermon stories (examined in chapter 2) were directed at his actual congregation in Kansas and, specifically, Endeavor Societies, Harper envisioned her work as Sunday School material. At the end of the nineteenth century there was a movement to publish and distribute Sunday School literature with a social justice message, but this process was more difficult for black authors. For more, see chapter 4, detailing the skirmish between white and black Baptists regarding denominational publishing houses.

155 Harper, "Note" in Iola Leroy, 219.

156 Harper, "A Factor in Human Progress," qtd. in Foster, 280 (emphasis added). 
and leaders of the race" to "consult on subjects of vital interest to our welfare." 157 The fictional characters who gather in Stillman's parlor are fairly transparent stand-ins for actual nineteenthcentury black leaders; Harper's reference to "Stillman," itself, is likely a nod to William Still, writer, speaker and reformer who served as her close friend and traveling companion during lecture tours in the South and who wrote the preface to Iola Leroy. As for the others, Harper assembles together several of the novel's main characters (Iola, her mother Marie, Dr. Latimer) with a variety of ministers (Revs. Carmicle, Cantnor, and Tunster), professors (Gradnor and Langhorne), and distinguished male and female community leaders (Mr. Forest, Hon. Dugdale, Mrs. Watson, and Miss Brown). ${ }^{158}$ What follows is a clever staging of the various conversations taking place across the country in the late nineteenth century, where black leaders (and others) debated controversial issues within their community: emigration, patriotism, (black) nation building, education, poverty, crime, generational divisions, home life, and the need for meaningful, practical religion. For her part, Iola delivers a paper on the "Education of Mothers," but, strangely, readers are not privy to her text, nor does Harper detail any specifics of Iola's argument. This is because Iola's (and Harper's) most passionate message to readers comes later, in Iola's homily to the group, which she gives in response to the Hon. Dugdale's paper, the "Moral Progress of the Race." This is not to say that Harper was unconcerned with the education of mothers - quite the contrary. Harper was a great proponent of reaching what her character Lucille Delany describes in this scene as the "field of Christian endeavor which lies between the schoolhouse and the pulpit."

157 Harper, Iola Leroy, 189.

158 With his adamant endorsement of emigration to Africa, Harper's Rev. Tunster certainly represents A.M.E.Bishop Henry McNeal Turner, a leading proponent of emigration in the late nineteenth-century. Regrettably, I have not been able to match the other characters with their real world counterparts, nor have I found other Harper scholars who have done so.

159 Harper, Iola Leroy, 197. 
gathered into homes, and a legally unmarried race to be taught the sacredness of the marriage relation." ${ }^{160}$ Many scholars have detailed Harper's views on "black republican motherhood" and the "embodiment of the mother" in her fiction. ${ }^{161}$ In her speeches and articles, too, Harper extolled the virtues of secure homes and moral, character instruction for children. However, in Iola Leroy these are preambles to Harper's more encompassing theology of the oppressed, which Iola heralds in her passionate address.

It is necessary, then, to examine Iola's words in their entirety, as they are the foundation of Harper's "black Nazareth" and even an expression of early black liberal theology. After stating that her "heart is full of hope for the future" and that "pain and suffering are the crucibles out of which come gold more fine than the pavements of heaven," Iola invokes a theology predicated on that suffering: ${ }^{162}$

And is there a path which we have trodden in this country, unless it be the path of sin, into which Jesus Christ has not put His feet and left it luminous with the light of His steps? Has the negro been poor and homeless? The birds of the air had nests and the foxes had holes, but the Son of man had not where to lay His head. Has our name been a synonym for contempt? 'He shall be called a Nazarene.' Have we been despised and trodden under foot? Christ was despised and rejected of men. Have we been ignorant and unlearned? It was said of Jesus Christ, 'How knoweth this man letters, never having learned?' Have we been beaten and bruised in the prison-house of bondage? 'They took

160 Ibid.

161 Michael Stancliff, Frances Ellen Watkins Harper: African American Reform Rhetoric and the Rise of a Modern Nation State. New York: Routledge, 2011. 140.; Geoffrey Sanborn, "Mother's Milk: Frances Harper and the Circulation of Blood." ELH 72.3 (Fall 2005):691-715. 710. See also: Boyd, "The Legacy of the Daughters of Ishmael: To Be Black and Female," Discarded Legacy, 113-146.; Alice Rutkowski, "Leaving the Good Mother: Frances E.W. Harper, Lydia Maria Child, and the Literary Politics of Reconstruction." Legacy 25.1 (2008):83-104.; Elizabeth Young, "Warring Fictions in Iola Leroy." American Literature 64.2 (June 1992):273-297.

162 Harper, Iola Leroy, 198. 
Jesus and scourged Him.' Have we been slaughtered, our bones scattered at the graves' mouth? He was spit upon by the mob, smitten and mocked by the rabble, and died as died Rome's meanest criminal slave. To-day that cross of shame is a throne of power. Those robes of scorn have changed to habiliments of light, and that crown of mockery to a diadem of glory. And never, while the agony of Gethsemane and the sufferings of Calvary have their hold upon my heart, will I recognize any religion as His which despises the least of His brethern. ${ }^{163}$

With a ministerial-like authority and careful explication of biblical text, Iola's speech leaves the group "spell-bound." 164 Dr. Latimer is "entranced," and Dugdale, who is overwhelmed, emits a "low" and "deep-drawn breath," stating, "She is angelic!"165 Her address invokes the style of call-and-response, through which she poses a question that relays the conditions African Americans suffered, and then responds with a scripture reference relating to the Savior's own experience in the flesh. Her progression is also chronological, according to the contents of the gospels - from Christ's first location in Nazareth to his crucifixion at Calvary. In other words, Harper maps the path of suffering trodden by Christ so that she might depict black Christians as following that very path. Here again is the language of the "Nazarene" and the "despised," to which Harper adds imagery of his physical oppression, homelessness, bondage, humiliation, and ultimate death at the hands of rulers who scorned him and his position as King. ${ }^{166}$ But Iola is careful to articulate, too, that this plight of suffering is also a path to victory. She declares, that

163 Ibid, 198-199.

164 Ibid, 199.

165 Ibid.

166 In 1888 Harper delivered a speech to the WCTU with language very similar to Iola's address in Iola Leroy. Harper also utilizes a call-and-response in paralleling Jesus's suffering with the hardship endured by black Americans, and concludes by encouraging her listeners to, "Learn to fight the battle for God and man as atheletes armed for a glorious strife, encompassed about with a cloud of witnesses who are in sympathy with the highest and holiest endeavors" (qtd. in Foster 285). 
"To-day that cross of shame is a throne of power," just as Harper had proclaimed, in an earlier speech, "What seemed to be a failure around the Cross of Calvary and in the garden, has been the grandest recorded success." ${ }^{\text {167 }}$

Harper clearly indicates with this scene that, while all attempts at cultural, economic, and educational rehabilitation are good and necessary for the black community, these efforts must be conducted with a sense of the "throne of power" to which African Americans have access as fellow sufferers with Christ—as the black Nazareth. This is, of course, an early version of black liberation theology, which, according to Anthony Pinn, requires black Christians to take on a "new posture toward the world." 168 Pinn continues: "In significant ways, [black] religious experience involves the placement of certain bodies in new contexts. . . through which the body becomes an interactive vessel promoting and contributing to God's plan for humanity." ${ }^{169}$ This encounter with the divine, he says, "involves looking both forward and backward" to what Cornel West calls the "tragic realism of the Old Testament" and the "proclamation of a coming kingdom by Jesus Christ." ${ }^{1170}$ But ultimately this liberation theology seeks a clear "goal of advancing a progressive future," which was at the heart of Harper's post-Reconstruction reform efforts. ${ }^{171}$ Just as Harper works diligently to portray racial injustice as a parallel to Christ's oppression, her vision asserts that, through the "throne of power" suffering is overcome - that while blacks continue to fight battle after battle for equality in the flesh, their spirits have already won eternal justice through the glory of Christ's resurrection. This assurance is, perhaps, what Dr. Gresham sees when "a glow of enthusiasm overspread[s]" Iola's face. ${ }^{172 ~ " T h e r e ~ w a s ~ a ~ r a p t ~}$

167 Harper, "The Great Problem to Be Solved," 222.

168 Pinn, 125.

169 Ibid.

170 West qtd. in Pinn, 125; and Pinn, 125.

171 Pinn, 125.

172 Harper, Iola Leroy, 171. 
and far-off look in her eye," he notices, "as if she were looking beyond the present pain to a brighter future for the race with which she was identified, and felt the grandeur of a divine commission to labor for its uplifting." ${ }^{173}$ Here, Iola acts as a "living epistle" like Aunt Kizzy, as she serves as a referent to the cause of Christ and lives out her own efforts at racial uplift.

If Harper wrote Iola Leroy as her own commission to young black Christians, her emphasis is on the role of black women, especially. The novel abounds with female heroines from Aunt Kizzy and Aunt Linda, to Lucille Delany, Iola, and Marie; and certainly Harper underscores that women's rightful place is in leadership roles in the community, starting with the home and working outward. Harper herself had an extensive resume on the part of women's organizations, something scholars have investigated at length, and Harper held leadership positions in the Woman's Christian Temperance Union, the National Association of Colored Women, the American Woman Suffrage Association, the Association for the Advancement of Women, the National Council of Women, the Women's International Temperance Society, and the National Women's Rights Convention. ${ }^{174}$ But while these associations appear, on the surface, to be concerned only with the public, legal, educational, and cultural spheres, Harper asserts in Iola Leroy that these efforts were sacred undertakings for black women. As Iola tells Dr. Gresham, she plans to "serve" her race and wishes "other Southern women felt as I do. I think they could do so much to help the colored people at their doors if they would look at their opportunities in the light of the face of Jesus Christ." 175

Harper's exhortation to black women also echoes a sense of their part in the Great

173 Ibid.

174 Harper served as Superintendent of the Colored Section of the Philadelphia Section of the WCTU, and later, as its Vice President; she also spoke at the 1866 National Women's Rights Convention and worked with Susan B. Anthony and Elizabeth C. Stanton to collaborate with various white northern women's societies. Also, see Foster, A Brighter Coming Day.

175 Harper, Iola Leroy, 182. 
Commission. For example, at the novel's end, Iola remarks, "I did not choose my lot in life, and the simplest thing I can do is to accept the situation and do the best I can."176 But her wording here should give any careful reader pause since, after all, Harper constructs the novel simultaneously to debunk racial categories and show that, when it comes to the social performance of identity, Iola did, in a sense, choose her "lot in life" when she "cast [her] lot with the freed people as a helper, teacher, and friend." ${ }^{, 177}$ But Iola insists she "did not choose her lot in life," once again harkening back to the idea of the "divine commission"; Iola believes her path in life is preordained and that she was guided by God to this "ministry of suffering" for the good of her (and his) people. ${ }^{178}$ As a woman following Christ's example, Iola also views community leadership and racial uplift as sacred duties, done unto God, and says she intends on building this "new era" around "a fuller comprehension of the claims of the Gospel of Jesus Christ, and their application to our national life."179

Harper's vision for the future is not merely mystical or spiritual; rather, it requires intensely practical service by "a people who have in their veins the blood of some of the strongest nations on earth" and who labor for God and their fellow men. ${ }^{180}$ In Iola Leroy and elsewhere Harper argues for improved education for children, literacy classes for adults, donations of money, food, and clothing, domestic instruction for husbands and wives, training in marketable skills, and an overall Du Bois-inspired infusion of black culture to inspire the next generation. A particularly useful example of Harper's vision for racial uplift is found in her 1878 speech to the Colored Women of America where, in the realm of educational improvement, she

176 Ibid, 182-183.

177 Ibid, 95.

178 Ibid, 171, 95. By saying she ministers to "her (and his) people" I mean to indicate that, through her liberatory theology Iola embraces the black community in order to help them, but this theology also indicates that the oppressed are closest to God and chosen by him for sacred purposes.

179 Ibid, 168.

180 Harper, "A Factor in Human Progress,” qtd. in Foster, 276. 
insists that "women as a class are quite equal to the men in energy and executive ability. In fact, I find by close observation, that the mothers are the levers which move education." ${ }^{, 181}$ Later, in an A.M.E. publication, she states that "the education of the intellect and the training of the morals should go hand-in-hand. The devising brain and the feeling heart should never be divorced."182 To accomplish this monumental task, Harper writes of the need for the "spirit of self-sacrifice and self-surrender," and once again returns to Christ's example for the template of such selflessness: "this same idea, ennobled and glorified, gathers around the cross of Calvary, and deepens around the garden grave, till it changes a symbol of horror and shame into a throne of power and an ensign of victory." ${ }^{, 183}$ Ultimately, just as Iola wanted fellow members of her race to view their opportunities at service through "the light of the face of Jesus Christ," Harper herself believed "self-sacrifice and self-surrender have been the golden cords that have lifted men nearer to God, and brought heaven closer to earth." 184

Finally, by proclaiming a "new era" of the "black Nazareth" through a woman, Harper follows a distinguished line of nineteenth-century black women writers who advocated for and practiced womanist theology. For this characterization I find Delores Williams's definition most helpful, as she writes, "Womanist theology emerged from [the] characteristics of black women's experiences of relation, loss, gain, faith, hope, celebration, and defiance. While its aim is discourse and work with black women in the churches, it also brings black women's experience into the discourse of all Christian theology, from which it has previously been excluded." 185 The goal of this approach is "to help black women see, affirm, and have confidence in the importance

181 Harper, "Colored Women of America," qtd. in Foster, 271.

182 Harper, "A Factor in Human Progress," qtd. in Foster, 276.

183 Harper, "A Factor in Human Progress," qtd. in Foster, 278-279.

184 Harper, Iola Leroy, 182, and "A Factor in Human Progress," qtd. in Foster, 279.

185 Delores S. Williams, Sisters in the Wilderness: The Challenge of Womanist God-Talk. Maryknoll, N.Y.: Orbis, 1993. xiv. 
of their experience and faith for determining the character of the Christian religion in the African-American community." Williams goes on to note that womanist "God-talk" as she calls it, "also branches off in its own direction, introducing new issues and constructing new analytical categories needed to interpret simultaneously black women's and the black community's experience in the context of theology." "186 It is dialogical and "a woman-centered tradition." 187 But while scholars have been willing to characterize Harper as a "black feminist" and write that her "portrayal of Iola [is] very much the portrayal of a nineteenth-century feminist," there has been very little discussion of Harper as a womanist theologian. ${ }^{188}$ Certainly, as Williams goes on to note, womanist theology is relatively new, and was first discussed as a field in the 1960s. But this characterization of female-centered theological empowerment does help to place Harper among women who brought their faith explicitly to bear on the cause of freedom. Further, Harper fashioned her novel to distill sacred texts to her readers in new, contemporary ways; she extolled the Person of Christ through a theology of the oppressed; and she asserted her power, as a woman, over God's sacred work on earth by exhorting black Christians to be involved in a modern-day "divine commission." This holy work, this ministry to and for the black Nazareth, is Harper's expression of lived theology — an experiential faith that places her in a long line of "black feminist theologians" who "found biblical precedent for leadership outside the church in charitable philanthropic work." 189

\section{Conclusion}

In building a sacred message for fellow African-American believers, Harper transforms

186 Ibid, xiv.

187 Ibid, xiv and 4.

188 Novak, 221 and Boyd, 221.

189 Evelyn Brooks Higginbotham, Righteous Discontent: The Woman's Movement in the Black Baptist Church, 1880-1920. Cambridge: Harvard, 1993. 131. 
her novel into a palimpsest, written over with sacred texts in a variety of forms - from the "living epistles" of individual believers, to Jesus as the Word made flesh, and the literal texts of Scripture. These texts and their living performances work to combat and reappropriate the discourse of racial discrimination by transforming their own "outcast blood" into a liberatory gospel through the blood of Christ. It is fitting, then, that Harper also chooses to include the text of a nineteenth-century blood hymn in the novel. Twice readers encounter a stanza from "Jesus Passing," an 1831 hymn by Dr. Thomas Hastings, which states, "Drooping souls no longer grieve, / Heaven is propitious; / If on Christ you do believe, / You will find Him precious." ${ }^{, 190}$ It would be difficult to assess whether Harper's readers would have known the song, but the work does appear throughout hymnal collections from the mid- to late-nineteenth century, and Hastings' hymns "were in common use more than by any other native writer." ${ }^{, 191}$ In the novel, Harper employs the text of the song — embodied through Iola's singing — to connect her characters through racial and familial bloodlines. When Robert hears Iola singing the song in one of the Civil War hospitals, he says it reminds him of his mother and, in the ensuing conversation, he learns he is connected (via bloodline) to Iola herself. Even in this seemingly minor aspect of the story Harper is at work, setting in motion her divinely-inspired plot and foreshadowing the essential role of Christian women as embodiments of the "precious" Christ. Ultimately the hymn is a microcosm of Harper's Christological message in Iola Leroy, promising atonement and hope for black believers who are intimately connected to the Incarnation through the blood of Christ. ${ }^{192}$ Indeed the hymn's final stanza praises the "Streaming mercy," of Christ's blood, stating

190 Harper, Iola Leroy, 114 and 154. In various sources the song title seems interchangeable, referred to as "Jesus Passing," "Heaven Is Propitious," and "Drooping Souls No Longer Mourn" (Julian 474).

191 Julian, 494.

192 Harper, Iola Leroy, 115. 
that, of its power, "Half has never yet been told / Yet I want to tell it."193 This final line could have come from Harper herself, as it celebrates and affirms what she called a "brighter day coming," and subsumes the racist blood discourse of the nineteenth century in Jesus's ultimate blood atonement for all people_-black and white alike: "Jesus' blood has healed my wound, / O the wondrous story! / I was lost, but now am found, / Glory! glory! Glory!"194

Throughout her life, Harper sought to reflect this story of Jesus, and to do so she risked her own safety and status. Harper attended white and black churches, spoken to white and black audiences, wrote for white and black-owned publications, and fashioned fiction, poetry, and essays for white and black audiences. In an era where racial violence erupted without provocation and the laws of the land sanctioned racism on a multitude of levels, her ability to traverse the color line and deliver a unifying message is a remarkable fact of history. Quite simply, Harper believed she was ordained by God with a holy message for the oppressed members of her race; and nothing would dissuade her from accomplishing her mission. But beyond her remarkable humanitarianism and social justice advocacy, Harper also leaves an indelible mark on American literary and theological history. Indeed, her eloquence, symbolism, theological expression, and progressive vision of a black Nazareth mark her as a "living epistle" all her own - a woman who testifies, even now, to "the incarnation of God's love and light."195

193 “Jesus Passing.” Hymnary. The Hymn Society of the United States and Canada. 2014. Web.

194 Ibid.

195 Harper, "Enlightened Motherhood," 288. 


\title{
Chapter 4: \\ To Follow the 'Suffering Savior': Sutton E. Griggs, God's Kingdom, and the Struggle of Race Reform
}

\author{
"New words are formed, \\ Bitter \\ With the past \\ And sweet \\ with the dream. \\ Tense, silent, \\ Without a sound, \\ They fall unuttered, \\ Yet heard everywhere." \\ —Langston Hughes, "A New Song",
}

As the National Baptist Convention convened in Nashville in 1899, its president

Reverend Elias Camp Morris addressed the assembly of black believers without equivocation, refusing to shoulder blame for the racial divisions that existed across the nation and within the Baptist church itself. He thundered: "The charge that this organization means to draw the color line, and thereby create prejudice in 'Negro' Christians against 'white' Christians, is without foundation."2 Instead, Morris rhetorically shifted responsibility to a white supremacist culture that had imposed a color line on blacks, even dictating "separate but equal" institutions and spaces: "We admit, however, that practically, and not constitutionally, the color line has been drawn by the establishment of churches and schools for the 'colored people' and the employment of missionaries, colporters, etc., to the colored people," a development that, Morris said, resulted "in the organization of associations and conventions by the Negroes in more than half of the

1 Excerpted from Langston Hughes, “A New Song.” The Collective Works of Langston Hughes: The Poems 19211940. Ed. Arnold Rampersad. Columbia, MO: University of Missouri, 2001. 144-145. The poem was originally published in 1933, the same year Sutton Griggs died. As a tribute to the fraught experience of black Americans, from slavery into freedom, the work ends with this call to resistance, through language - a method of assertion Griggs championed throughout his life and career.

2 Elias Camp Morris, "President's Annual Address at the National Baptist Convention, Nashville, Tennessee." Sept. 1899. Keynote Address. Sermons, Addresses and Reminiscences and Important Correspondence. National Baptist Publishing Board: Nashville, 1901. 93-94. Emphasis added. 
States in the Union." "Forced to make their own way, Morris insisted it was their "duty" as marginalized believers to "do everything in their power to build up the cause of Christ in and through these agencies."4

Morris's words are an apt reflection of the frustrations and efforts of black Baptist ministers, writers, and speakers who, at the turn of the century, were facing unprecedented divisions, even while witnessing what Morris called "unparalleled progress" in their denomination..$^{5}$ At the time of his address, the Baptist church was the largest denomination among American blacks, with more than one-and-a-half million members, more than ten thousand black ministers, millions of dollars in church property, and a growing sense of political and social clout in an increasingly volatile South. ${ }^{6}$ But such "progress" also testified to deepening racial divisions across the national and ecumenical landscapes - tensions that both separated and drew black believers together, and made them wary of "combinations" with whites, on any level. Just one year prior, Morris had addressed the Convention with a similar yet less strident focus on racial divisions, insisting, "What we need, and what we must have if we are ever to command the respect of our white brother, is unity." In fact, in 1898 Morris suggested "an all-wise Providence has the matter in hand, and... he is effectually using the other race to

3 Ibid, 94. It is likely that Morris refers here to the Supreme Court case of Plessy v. Ferguson, which had just been decided in 1896. The landmark ruling upheld the constitutionality of state laws requiring racial segregationconsidering such accommodations "separate but equal."

4 Ibid, 94.

5 Ibid, 93.

6 See Paul Harvey, Redeeming the South: Religious Cultures and Radical Identities Among Southern Baptists, 18651925. Chapel Hill, NC: University of North Carolina, 1997. 46-52. Harvey notes that by 1894 , " $54 \%$ of African American Christians were Baptists, numbering slightly over one million. The 1906 religious census listed about 2,250,000 black Baptists, comprising about $60 \%$ of churchgoers" (46). Also see Morris's 1898 keynote address to the National Baptist Convention, where he claims, "have 1,600,000 people who are as loyal to their Churches as any that ever lived; and if we can succeed in getting the 14,000 Baptist ministers united in the great work before us, no power on earth can prevent our carrying to success every object of this Convention" (86). Just one year later, in 1899, Morris asserts, "I have no doubt that the census of 1900 will show nearly two million Negro Baptists in census of 1900 will show nearly two million Negro Baptists in this country" (103).

7 Morris, "President's Annual Address," (1898) 86. 
drive ours together," so that "those who yesterday were the most bitter opponents of Negro enterprises-Negro Conventions, Negro Churches, Negro Associations, Negro papers, Negro magazines, Negro song books etc.—are to-day loudest in their claim for such organizations." 8 On the issue of "combinations" with white Baptists, Morris hedged, saying in 1898 he was "in favor of cooperation" but only "for that cooperation which indeed cooperates." 9 Such equivocation glimpses what would become a foundational dilemma for black Baptists entering the new century: would the Convention and, indeed, would black believers throughout the nation, best advance the cause of equality through separatism or cooperation, and which solution would come on their own terms? For Morris, the answer came, albeit veiled, in his fiery 1899 address, where he heralded black "agencies" of change and omitted any mention of cooperation with whites for national endeavors. ${ }^{10}$

In the audience for Morris's 1899 address was a young minister and novelist whose own father had served as Convention president and who had, himself, recently captured this dilemma of racial progress in his first work of fiction. ${ }^{11}$ Sutton Elbert Griggs, originally from Texas and

8 Ibid.

9 Ibid, 85.

10 It is important to note that Morris does discuss interracial work outside the U.S. border, stating that black believers must work with white believers in Cuba: "We are in duty bound to aid in carrying the Gospel to the Cuban people. Like the black troopers who went up El Caney and saved the lives of their white comrades from destruction, so must the Negro Baptists of this country join their white brethren in carrying the Gospel of the Son of God to that people." But regarding church work and, more specifically, the Baptist church in the United States, Morris is silent on the issue of "cooperation" or "combinations," both of which he supported in the 1898 . See Morris, "President's Annual Address" (1899), 97.

11 See Finnie D. Coleman, Sutton E. Griggs and the Struggle Against White Supremacy. Knoxville: University of Tennessee, 2007. 12. Unfortunately space does not allow me to recount the remarkable career of Sutton Griggs's father, Allen R. Griggs, which Coleman so wonderfully narrates in her work. Allen fought through a racist education system in Texas and went on to divinity school, spent decades as a traveling preacher (often holding pastorates at several churches simultaneously), advocated white and black cooperation on the part of race reform, helped to found four black colleges and one religious academy, was a writer and editor, established the Baptist Journal (the first black newspaper in Texas), published multiple serials on religious and race matters, was friends with Booker T. Washington, was present during the National Baptist Convention's founding, and served as the Convention president for three years when "the membership of the convention was larger than any other organization of blacks outside of continental Africa" (12). Indeed, as Coleman notes, "It is something of a shame and a wonder that Allen R. Griggs is not better known in African American cultural history" (13). 
recently installed as pastor at the First Baptist Church in Berkley Virginia, had just months before the Convention published and hand-peddled his first novel, Imperium in Imperio. The novel is a complex tale of race in the late nineteenth century-encapsulating the insidiousness of white supremacy in education, law, church, government, science, and even the individual psyches of black, white, and mixed-race Americans. As its title suggests, the novel examines the reality of black Americans who live every day as part of a "nation within a nation"; but the narrative also gestures toward the liberatory possibilities of existing apart from white society as an independent black nation. This approach allowed Griggs to reverberate both the cooperative and separatist arguments regarding race reform at the turn of the century-fractious debates Morris had identified in his Convention addresses to the largest gathering of black believers in America, and concerns that permeated Griggs's own thinking for decades.

But while Griggs was one of the most prolific black writers of his time, and while he traveled in the orbit of the other memorable race leaders, he and his work have been largely forgotten in the march of history. In recent years, several studies have sought to resurrect his voice and contributions — most notably a wonderful collection of essays titled, "Jim Crow, Literature, and the Legacy of Sutton E. Griggs," edited by Tess Chakkalakal and Kenneth W. Warren, and a meticulously researched biography by Finnie Coleman. And yet Griggs still suffers from a number of persistent and damaging misreadings, most often due to a scholarly insistence on charting turn-of-the-century race relations along two poles - the accommodationists, represented by Booker T. Washington, and separatists (or nationalists) as represented by W.E.B. DuBois. As I will later discuss, and as scholars such as Coleman and John Ernest have lamented, this insistence on the Washington-DuBois binary flattens the era by overlooking the vibrant debate and nuance that characterized race reform at the turn of the 
century. ${ }^{12}$ Simply put, the decades of tumultuous change from theological shifts to institutional schisms, from unprecedented literary profusion to impassioned political wrangling was too dynamic, too chaotic, to be explained with fixed categories or tidy narratives.

This chapter argues, then, that a scholarly turn to Griggs does not simply add dimension to a narrative we already know, but that by piercing the surface of Griggs's work as a novelist, pamphleteer, speaker, minister, and activist, we access a forgotten stratum of American literary history that challenges our concept of race reformers and provides a more flexible account of the era. Griggs's writing acts as an instructive testimony to this racial past while also linking to a complex web of black leaders who shaped sacred and secular policy. Such individuals include the aforementioned Elias Camp Morris, W.B. Johnson, Thomas Fuller, Richard H. Boyd, and Richard Abner, and women such as Charlotte Moon, Nannie Helen Burroughs, and Annie Armstrong. As leading figures in the Baptist church, these individuals left a rich textual map of African-American activism in an era that is often misunderstood and has yet to garner the study it deserves. By reclaiming Sutton Griggs, then, we gain access to a "nation within a nation" of thinkers, writers, religious leaders, and activists who were well known in their time and whose lives tell a variegated story of America we tend to forget.

More specifically, this chapter argues that it is in Imperium that Griggs builds a scaffold for activism in the next century, predicated on the doctrine of the "suffering Savior" and an absolute, undying loyalty to the African-American community through individual self-denial. Often these ideals translated into action in conflicting ways. For this reason I will focus in on the novel while simultaneously glancing forward at Griggs's other works of fiction and non-fiction,

12 See Coleman, Sutton E. Griggs, 33; and John Ernest, “Harnessing the Niagara: Sutton E. Griggs's The Hindered Hand. Ed. Tess Chakkalakal and Kenneth W. Warren. Jim Crow, Literature, and the Legacy of Sutton E. Griggs. Athens, Ga: University of Georgia, 2013. 186-213. 
as well as his activities within the Baptist community. As Griggs's first novel, Imperium is a starting point and a useful dialectic on the uncertainty of African-American progress at the dawn of a new century; the tale also encapsulates the "twoness" that characterized Griggs's thinking. The reality is that any effort to fix Griggs within one camp or another-militant or accommodationist — fails even as it begins, as the preacher-writer advocated a whole spectrum of approaches to race reform throughout his career (and sometimes even within the same few years). This is exactly the value of including Griggs in our conception of race relations at the turn of the century: in a chaotic environment, where prejudice was whitewashed through legal sanction, where intangible racial categories were fixed, and where churches preached the cause of Christ even while supporting horrific violence against black believers, nothing was certain. Griggs's policies on cooperation and separatism shifted and were unsettled because his culture and his church were unsettled.

Ultimately, the one constant for Griggs was his belief that Christ's example of self-denial should be central to every black Christian's struggle for equality. While glimpsed in Imperium, this doctrine of self-sacrifice took on a more noticeable presence in Griggs's later works of nonfiction, and in this way Imperium serves as a proving ground for Griggs's sacred endeavors. The novel's overt narrative of racial improvement is undergirded by a theological tension that both complicated Griggs's race work and compels us forward to chart the dynamic and sometimes contradictory ways black theology shaped racial activism at the turn of the century.

\section{A Man of His Time: Griggs in Context}

In many ways, Sutton Griggs represents a felt absence in American literary scholarship of the post-Civil War years. For decades, religious and black-owned presses churned out novels, 
pamphlets, Sunday School material, tracts, newspapers, and other serials with zeal, but most literary scholars today would be hard pressed to name even one of these published writers. As Paul Harvey notes, in the late nineteenth century "African American religious thinkers responded vigorously" to white supremacist policies by publishing works of religious edification and racial uplift. ${ }^{13}$ A large swath of African-American literature published in the late nineteenth century came from black-owned religious publishing houses (such as the National Baptist Publishing Board, a denominational press), or were self-published by black writers themselves. With the exception of Imperium in Imperio, Griggs published all of his fiction through a press he established and owned - the Orion Publishing Company; and later when he moved to Memphis, he founded the National Public Welfare League, which served as the press for his works of nonfiction, as well as other political tracts. ${ }^{14}$ Owning a press was a remarkable step for any black writer, as it guaranteed a voice and marshaled resistance to the rise of white supremacist print culture that was increasingly stoking tensions in the South. ${ }^{15}$ As Finnie Coleman notes, Griggs "developed Orion specifically to publish his fiction and the work of other black writers who wanted to avoid the editorial restrictions placed on black writers by white presses. ${ }^{.16}$ Even the most renowned black writers like Charles Chesnutt or Paul Laurence Dunbar faced uncertainty when it came to publication and often had to relinquish some control over their texts in order to get their works printed. For this reason, Griggs "felt that the freedom he enjoyed with Orion was a freedom that all black writers should experience," leading him to write, publish, and support

13 See Paul Harvey, Freedom's Coming: Religious Culture and the Shaping of the South from the Civil War through the Civil Rights Era. Chapel Hill: University of North Carolina, 2005. 45. Emphasis added.

14 For more on the National Baptist Publish Board, see Harvey, Redeeming the South, 70-72, 244-247; and see James Melvin Washington, Frustrated Fellowship: The Black Baptist Quest for Social Power. Macon, Ga: Mercer University, 1986. 190-196 For more discussion of Griggs's publishing companies, see Coleman, 24-27.

15 In his biography of Griggs, Walker devotes his first chapter to detailing what he calls "Anti-Black Propaganda," reminding readers that much of the printed word in the late nineteenth century "projected a bigoted image of the black man" (9).

16 Coleman, 24. 
other black writers for the majority of his adult life. ${ }^{17}$

Collectively, ministers produced texts that changed the racial landscape of their time, even while shaping the next generations of activists. Denied an equal voice in American politics and marginalized by a white supremacist "Christian" culture, these black theologians wrote as a way to process their community's fraught identity, to respond to persistent racial divisions and escalations in violence, and to envision a more promising future. Of these writers, Sutton Griggs was one of the most prolific, authoring five novels and at least thirty non-fiction texts all relating to the problem of race in America. Griggs knew and worked alongside other nationally known black leaders, and he traveled and spoke extensively, so that in addition to his self-published works, his name also appeared frequently in black-owned newspapers from Chicago to Richmond, New York to Nashville. By turning to Griggs, then, we are closer to understanding what Paul Harvey calls, "the saga of the sixty-year period after the Civil War," which "still lacks a narrative that interprets the black and white Baptist experience in the South within the central themes of American cultural history."

And yet Griggs's catalog is difficult to access, particularly because he self-published his works and most of them are no longer in print. Available to us now are his novels and a few pamphlets, as well as the preserved audio of several sermons, which Steven C. Tracy reintroduced to the scholarly world in $1986 .{ }^{19}$ Indeed there is a disconnect regarding Sutton Griggs as author, as the bulk of his writings have been lost or misplaced, even while some scholars

17 Ibid.

18 Harvey, Redeeming the South, 3. For figures regarding Griggs's publications, see Coleman, Sutton E. Griggs, ix. 19 See Steven C. Tracy, "Saving the Day: The Recordings of the Reverent Sutton E. Griggs." Phylon 47.2 (1986):159-166. The sermons were recorded in a Memphis studio on September 18 and 29, 1928. Most importantly, Tracy notes that the recordings are "the religious Griggs and not the novelist," which remarks upon an interesting perception of Griggs's careers as dichotomous: Griggs the minister was not necessarily Griggs the novelist, and Griggs the novelist was not necessary speaking from the same subject position of Griggs the minister. This is something I address later in this chapter. 
assert that his novels reached a wider audience than the works of Chesnutt or Dunbar. ${ }^{20}$ Tess Chakkalakal explains that this misconception surrounding Griggs's "popularity" stems from a bit of historical speculation by Hugh M. Gloster: In 1948, Gloster penned an oft-cited article that praised Griggs for his industriousness and publishing savvy, writing that though his novels were "virtually unknown to the white American reader" they were "probably more widely circulated among Negroes than the fiction of Chesnutt and Dunbar."21 Over time, Chakkalakal states, Gloster's "probably" became a certainty. ${ }^{22}$ But the reality is that Griggs struggled to find an audience for his novels and wrote in his 1914 autobiography The Story of My Struggles that he had abandoned fiction due to an anemic black readership. He wrote, "I... lifted the blame from myself and sorrowfully laid it at the door of my race. I came to the conclusion that adequate support was not to be secured for efforts along this line, however effectively one might state the Negro’s case.” ${ }^{23}$ Considering his novels "financial failures," Griggs said he "decided to abandon the field of literature and devote [his] time fully to my other labors," which resulted in decades of devotion to the Baptist denomination and his dual role as minister and race leader. ${ }^{24}$ Indeed, in self-publishing, marketing and selling his own works, Griggs had chosen a difficult road. He did not have access to the resources or backing of white publishing houses, nor did he benefit from powerful editors such as George Washington Cable or William Dean Howells who both championed the writings of contemporary black authors. In part, this is the reason much of

20 See Gabriel A. Briggs, "Imperium In Imperio: Sutton E. Griggs and the New Negro of the South." Southern Quarterly 45.3 (Spring 2008):153-176. 154.

21 For discussion of the staying power of Gloster's comment, see Tess Chakkalakal, "Reading in Sutton E. Griggs." Ed. Tess Chakkalakal and Kenneth W. Warren. Jim Crow, Literature, and the Legacy of Sutton E. Griggs. Athens, GA: University of Georgia, 2013. 143-166. For Gloster's original discussion of Griggs's readership, see Hugh Gloster, "The Negro in American Fiction." Phylon 4.4 (1943):335-345

22 Chakkalakal, "Reading," 143.

23 Sutton E. Griggs, The Story of My Struggles. Memphis, TN: The National Public Welfare League, 1914. 11.

24 Ibid. For additional discussion on Griggs's various publications and the lackluster response they received from black readers, see Coleman, Sutton E. Griggs, 20-28. 
Griggs's publications have been lost to time or are, more than likely, forgotten in the recesses of an archive or private home, just waiting to be discovered.

Those of us hoping to recover Griggs also have little access to the details of his life story, at least by way of any first-person accounts. Finnie Coleman explains: "With the exception of a family Bible held in the archives of the Dallas Historical Society, no private documents have been recovered that would disclose a more detailed private history of Sutton E. Griggs and his immediate family., 25 In fact, Coleman states, "There are no surviving letters, and his twothousand-volume library seems to have simply vanished."26 Such a dearth of primary materials is quite staggering for a figure as public, as prolific, and as well connected as Sutton Griggs. For this reason it was all the more remarkable in 2012 when Tess Chakkalakal found a letter from Griggs to African-American historian Carter G. Woodson, in the Woodson papers at University of North Carolina. Griggs wrote the letter in 1918 simply to request a copy of Woodson's Journal of Negro History; but, as he praises Woodson's efforts, we are afforded a glimpse into Griggs's philosophy of race reform — one that insists on raising the black race from within while simultaneously repairing the fractious relationship with whites, who deemed African Americans inferior. He wrote: "Permit me to congratulate you upon undertaking a matter of such vast importance to the Negro race. The facts which you have uncovered, and shall uncover in the future, will do much toward strengthening self respect in our race, and heightening the esteem in which we are held by other races." ${ }^{27}$ The letter is typed, but it does contain Griggs's signature and is printed on his own letterhead from the National Public Welfare League. This is the only known document that includes Griggs's signature, and as Chakkalakal states, the letter's contents

25 Coleman, Sutton E. Griggs, ix.

26 Ibid.

27 Tess Chakkalakal, "Who Was Sutton Griggs?” Humanities Writ Large. Ed. Laura Eastwood and Robert Zimmerman. Duke University. 26 March 2012. Web. 20 Feb. 2015. 
“reveal quite clearly Griggs's mindset about the purpose of scholarship, i.e., building racial selfrespect and burnishing the prestige of the race: pure vindicationalism." 28 It also provides a "trace of the living hand of an important author who was almost allowed to vanish." ${ }^{29}$ Griggs's letter reminds us, too, that as a writer and activist he maintained a DuBoisian twoness of vision, balancing how various developments or actions in the black community could improve the race itself, and then how those gains would be perceived by those outside the community (most often by white persons with political and financial power).

But there is an even more curious gap in Griggs scholarship relating to his theology. Scholars are careful to mention his occupation as a minister, but, other than Walker's partial biography of Griggs, there is no discussion of his theology or the ways in which Griggs-theminister informed and was held in tension by Griggs-the-reformer. And yet his vision of Christianity was central both to his writing and activism. Even in studies on Imperium, his most discussed novel, scholars have yet to examine how the text blends sacred with secular, Christian doctrine with racial improvement. This is despite the fact that scholars have examined Griggs's novel in a host of other contexts including citizenship, embodiment, nationalism, the borderland, utopia, masculinity, trauma, and homelessness. ${ }^{30}$ Walker aptly characterizes this dichotomized approach to discussing Griggs, arguing, "At best there have been attempts at simplifying a very complex social thinker who infused both Christian teachings and science in his ideas.

28 Ibid.

29 Ibid.

30 See Maria Karafilis, "Oratory, Embodiment, and U.S. Citizenship in Sutton E. Griggs's Imperium in Imperio “ African American Review 40.1 (2006): 125-143.; Stephen Knadler, "Sensationalizing Patriotism: Sutton Griggs and the Sentimental Nationalism of Citizen Tom." American Literature 79.4 (December 2007):673-699.; Caroline Levander, "Sutton Griggs and the Borderlands of Empire," American Literary History 22.1 (2009):5784.; Lynn R. Johnson, "A Return to the Black (W)hole: Mitigating the Trauma of Homelessness in Sutton E. Griggs's Imperium in Imperio. The Southern Literary Journal 42.2 (Spring 2010):12-33.; Pavla Veselá, "Neither Black Nor White: The Critical Utopias of Sutton E. Griggs and George S. Schuyler.” Science Fiction Studies 38 (2011):270-287.; and Robert Nowatzki, "'Sublime Patriots': Black Masculinity in Three African-American Novels." Journal of Men's Studies 8.1 (Fall 1999):59. 
Consequently, segmentation and partial investigations have resulted in only variegated confusion as to who Griggs was and what he meant to his era." 31 This "variegated confusion" led Robert A. Bone to judge that, "Griggs's blind impulse toward retaliation and revenge is striving for mastery with a more moderate, and more realistic approach. ${ }^{, 32}$ In contrast, Griggs himself argued for a much more sacred interpretation of these "strivings," stating that, "This is not a Negro problem, nor a white man's problem. It is a test of the ability of Christianity to handle that greatest of all human problems, the problem of adjusting race to race upon terms that are fair to both, and that will allow both to unfold all the good that God has wrapped up in their souls. ${ }^{33}$ In other words, while scholars such as Bone interpret Griggs's work as a manifestation of his personal rage and political cunning, Griggs actually regarded his work as sacred duty and as an effort to bring Christians — white and black — in line with God's vision for humanity. Elsewhere Wilson Moses critiques what he calls Griggs's "Victorian sentimental racialism" that is "exemplified" in "selfaccusatory tendencies." ${ }^{34}$ But rather than "self-accusatory," Griggs believed his works touted the Christian doctrine of "self-renunciation," stating, "The core of the Christian religion is selfrenunciation, and that is likewise the foundation of society."

Fortunately, there remains a cache of historical evidence that helps contextualize Griggs's theology and faith-centered activism, both of which can be traced to his position within the black Baptist church. Griggs was truly a product of (and a shaping influence on) this denomination, so

\footnotetext{
31 Randolph Meade Walker, The Metamorphosis of Sutton E. Griggs: The Transition from Black Radical to Conservative, 1913-1933. Memphis: Walker Publishing, 1991. 94. I am much indebted to Walker's careful archival research on Griggs and to his excerpts of Griggs's publications that are now out of print. I refer to Walker's work as a "limited biography," as it only explores a portion of Griggs's life, albeit the most productive and publicly active decades of his life.

32 Robert A. Bone, The Negro Novel in America. New Haven, CT: Yale University, 1965. 33.

33 Griggs, Paths of Progress; or, Co-operation Between the Races, A Series of Addresses, Articles, and Essays. Memphis: National Public Welfare League, 1925. 18.

34 Wilson Jeremiah Moses, The Golden Age of Black Nationalism, 1850-1925. New York: Oxford, 1978. 192-193.

35 Griggs, Cooperative Natures and Social Education, A Philosophy of Civic Life. Memphis: National Public Welfare League, 1929. 85.
} 
an examination of this inheritance lays a foundation for understanding his vision of the black community. Raised by his Baptist minister father, who himself went on to become president of the National Baptist Convention, Griggs was brought up and schooled in Baptist doctrine-from Sunday School at a variety of central Texas Baptist churches to Baptist High School (which his father founded), and from undergraduate study at (Baptist) Bishop College (another school his father founded) to a seminary degree from (Baptist) Richmond Theological Seminary (where his father also studied). Professionally, Griggs attended numerous gatherings of the National Baptist Convention, served as the secretary to that Convention's Educational Board, worked with a variety of local and regional Baptist organizations, and was pastor to multiple Baptist churches in Virginia, Tennessee, and Texas. ${ }^{36}$ In the last years of his life, Griggs worked with white Southern Baptists to establish the American Baptist Theological Seminary, and was unanimously elected as president of the Seminary in 1925. For all of these reasons, Griggs cannot be divorced from his Baptist theology, and truly his local activism and literary endeavors must be understood within the context of a national Baptist identity. ${ }^{37}$

As a man who greatly shaped black Baptist thinking, Allen R. Griggs perhaps had the most profound influence on his son Sutton. In ways practical and figurative, Sutton followed in his father's footsteps for much of his early career, and, even from an objective standpoint, Allen Griggs was an impressive and astonishingly productive leader in the black community. He had been born a slave in Georgia in 1852, but rose to be one of the most prominent black Baptist

36 For biographical information on Griggs, see Coleman, especially "Preface" and "Chapter 2: Death of the New Negro."

37 For more details on Sutton Grigg's early life, see especially Coleman, "King Cotton, the Griggs Family, and the Making of the 'New Negro,"' in Sutton E. Griggs, 1-28; also see Walker, 13-33. For a helpful timeline on Griggs's life, alongside important dates in national race reform movements and developments in the black Baptist church, see Chakkalakal (Ed.), Jim Crow, Literature, and the Legacy of Sutton E. Griggs, 282-288. And for a more broad discussion of the black Baptist church in the post-Civil War decades and into the twentieth century, see Harvey, Redeeming the South; and see Washington, Frustrated Fellowship. 
leaders in Texas and "one of the most revered black men in the Baptist circles of the South.",38 Allen Griggs exhibited a lifelong devotion to church, family, and education — three distinct areas he felt were essential to racial and religious improvement. In the span of his career, Allen founded five hundred churches in and around Texas, built the first black high school in Dallas, oversaw the establishment of four black colleges, and in addition to serving with the National Baptist Convention, he worked as an educational reformer, traveling minister, writer, and editor. ${ }^{39}$ For the elder Griggs, the church "not only represented salvation" but it enabled him to "dedicate a significant portion of his life to building an educational infrastructure in Texas that would support black academic endeavors from grade school to graduate studies. ${ }^{, 40}$ In an 1895 history of the Richmond Theological Seminary (from which Sutton graduated in 1894), Allen reflected that his time at the seminary had made him "see the importance of intelligence and long for it more and more. I feel that I have been able to serve my people better and more acceptably in the cause of Christ. My course of study has enabled me to reach my people in many ways that I knew not of before; therefore, I feel myself drawn closer to them."41 Sutton, too, was also drawn to "serve [his] people," and like his father, he looked to the future with a dual commitment to practical ministry and vigorous education "in the cause of Christ."

Ultimately the ecumenical activities and bold sentiments of Allen and Sutton Griggs help us chart the rising wave of black reformers who worked in and through the black Baptist church

\footnotetext{
38 Coleman, 13.

39 See Coleman, 11-13. Coleman also notes that, "diverse sources, including his obituary, substantiate his son's claim that he found and built more than 500 churches in and around Texas" (12). To understand the impact of these activities at the time, Coleman notes "that in 1860, there were only 286 Baptist churches, black and white, in all of Texas. While these numbers are stunning, Griggs's vita reveals a level of industry that is in keeping with such an accomplishment" (12).

40 Ibid, 11-12.

41 Qtd. in Charles H. Corey, A History of the Richmond Theological Seminary. Richmond, VA: J.W. Randolph Company, 1895. 166
} 
at the turn of the century. ${ }^{42}$ Black churches, collectively, took a more political and social role in the late decades of the nineteenth century, realizing they could not rely on the federal government to intervene on behalf of racial equality. Among other developments, an 1883 Supreme Court decision declared the Civil Rights Act of 1875 "unconstitutional," effectively upholding white supremacy and ushering in an era of even deeper racial divisions and continued legalized racial violence. ${ }^{43}$ But the ruling also galvanized black organizations, including churches, which redoubled their efforts for the cause of equality. As a denomination, black Baptists were the nation's largest, most powerful, and increasingly contentious body of black believers at the turn of the century, and as a contingent black Baptists were interested in furthering their work through both spiritual and social justice endeavors. The dilemma was how best to proceed. Should African Americans join in a spirit of cooperation and work with whites toward a common goal? Or should separatism prevail, so that blacks would have autonomy over their future in a way that was no longer dependent on whites? Indeed, at meetings of the National Baptist Convention, at state conventions, in church congregations, and even in the writings of individual leaders, black Baptists were facing a schism over how to move forward for AfricanAmerican rights. As Paul Harvey so clearly characterizes it: "Black religious leaders face the same questions that sparked controversies in many black organizations of the era. Did accepting white money inevitably mean bowing to white dominance of efforts toward education and independence? If whites donated money to black institutions on the condition of white

42 These particular dates correspond with the broader focus of my study, here, and underscore the fact that while "the separate religious life that enslaved blacks developed before the Civil War" this faith practice "took an institutional form after 1865, as African Americans believers withdrew from white congregations" (Harvey 12). By 1925, the southern religious landscape had changed due to northern migration of blacks and the rise of a distinct southern evangelicalism; these debates over separatism and cooperation were still very much alive and just as contentious, eventually fueling the Civil Rights movement of the mid-century.

43 See William E. Montgomery, Under Their Own Vine and Fig Tree: The African-American Church in the South, 1865-1900. Baton Rouge, LA: Louisiana State University, 1993. 193-197. Also see Daniel W. Stowell, Rebuilding Zion: The Religious Reconstruction of the South, 1863-1877. New York: Oxford, 1998. 
leadership, was this a sacrifice of the principle of black autonomy?",44

Regionally, delegates to Baptist conventions in Texas were "among the first to skirmish over ground that would soon witness numerous intraracial battles," and Allen and Sutton Griggs were at the nexus of these debates. ${ }^{45}$ Often at issue were the ways in which financial donations from whites impinged upon black agency. For example, when the black Baptist convention in Texas voted in 1888 to divide its financial support between two schools-Bishop College and Guadalupe College - the American Baptist Home Mission Society (ABHMS) intervened, arguing that Guadalupe should be a "lower-grade feeder school" and "higher educational resources" should be "concentrated on Bishop College."46 Not surprisingly, Guadalupe had been established by black Baptists and Bishop was founded by the ABHMS in cooperation with black Baptist leaders, including Allen Griggs. In this debate, Allen, of course, sided with the integrationists and became labeled as a "cooperationist" who "work[ed] for the white people.",47 He refuted the claim by condemning the "superstitiousness" that led "some of our people to believe that every dollar a white man turns loose on a colored man he see where he can make two out of it." ${ }^{48}$ But it was partially due to this schism that Sutton carved out his own space in the Baptist community by vehemently supporting the separatist movement. Along with Richard H. Boyd and Richard Abner, he established the General Missionary Baptist Convention of Texas as a separatist organization, taking as their rallying cry, "The Holy Spirit come to us and forbid the Negro taking a second place." 49 For his part, Griggs was especially critical of how white money was filtered through the Home Mission Society and stated, "We believe in letting all our

44 Harvey, 68.

45 Ibid, 69.

46 Ibid, 69.

47 Ibid, 69.

48 Qtd. in Harvey 69.

49 Qtd. in Harvey, 69. 
Baptist schools live.... [Whites] simply say let your field grow up in weeds and work my land for fifty years. Let your wife and children do without the home for fifty years, and work for me; but they forget when the fifty years are out the Negros is just where he was when he started. Not one whit higher, cornered and unprotected." ${ }^{" 50}$ It was these debates, primarily but not exclusively, that led to the establishment of the National Baptist Convention itself in $1895 .^{51}$

Such skirmishes were not always financial in nature, however, and in fact one of the largest schisms in the denomination involved black access to national Baptist publishing houses. As noted earlier in this chapter, black authors faced many barriers to publication, but black ministers were outraged that they also encountered racial prejudice from their own denominational press. An example of this injustice occurred in 1889, when Revs. William J. Simmons, Emmanuel K. Love, and William H. Brooks were first told by the Director of the American Baptist Publication Society, Benjamin Griffith, that the Society would print their doctrinal essays in the Baptist Teacher. ${ }^{52}$ But white southern Baptists mounted a fearsome resistance through the Southern Baptist Convention, and the offer was withdrawn, citing a desire to avoid the "wickedly ambitious, unprincipled elements" among African Americans and not encourage "a contempt for law and order [or]... deeds of violence and death." ${ }^{, 53}$ Eventually such discrimination led Emmanuel Love, a cooperationist, to change his position, believing black Baptists had "grown too largely to be parasites." ${ }^{, 54}$ Like Griggs, Love argued that "the color line is already drawn" and separate black publishing houses were "a question of race pride and of

50 Qtd. in Harvey, 69. For more on these divisions in other states, see Harvey, 70-71 and James Melvin Washington, Frustrated Fellowship, 65-70. Harvey notes that similar splits occurred between white and black Baptist financial support of schools in Georgia and Virginia, while debates surrounding funding for publication plagued the Baptist conventions in Georgia, Virginia, and the Carolinas.

51 Harvey, 70.

52 See Harvey, 70. Also see Jacqueine M. Moore, Leading the Race: The Transformation of the Black Elite in the Nation's Capital. Charlottesville, VA: University of Virginia, 1999. 71-73.

53 Southern Baptist Convention statement qtd. in Harvey 71.

54 Qtd. in Harvey, 72. 
race gain in dollars and cents. ${ }^{, 55}$ In 1896, just one year after the formation of the largest black Baptist convention in the nation, that Convention established the National Baptist Publishing Board, led by Griggs's fellow Texas separatist and sometime ally Richard H. Boyd; by the midtwentieth century it was the largest black-owned press in the country. ${ }^{56}$

In the midst of these tumultuous discussions of racial oppression and racial pride stood Griggs - a devout believer who believed in the liberatory power of Christ, who was loyal to the Baptist denomination, and who increasingly saw national Baptist leaders exhibit white supremacist thinking in their governance. He responded by speaking out against white Baptist paternalism in Texas, by countering racist allocations of resources, and by establishing his own press in order to inform other black believers and fan the flame of resistance. Imperium in Imperio, then, was his effort to characterize the multi-layered dilemma of racial improvement for his fellow black Americans, so they could chart a better path forward, so the New Negro could emerge in a spirit of resistance and empowerment through Christ's guidance.

Imperium in Imperio; or “A New Song” for a "New Negro",57

Twenty-six years before Alain Locke proclaimed the era of the New Negro in 1925 , Sutton E. Griggs declared that, "The cringing, fawning, sniffling, cowardly Negro which slavery left, has disappeared, and a new Negro, self-respecting, fearless, and determined in the assertion of his rights was at hand."58 This line, perhaps the most quoted from Griggs's Imperium in

55 Ibid.

56 Ibid. Harvey also dedicates part of chapter 8 of Redeeming the South to discussing Boyd and his separatist actions on the part of black Baptists, in the era of Jim Crow.

57 Inspiration for this section's title is taken from Langston Hughes's poem, "A New Song," also quoted in the epigraph to this chapter.

58 Sutton E. Griggs, Imperium in Imperio. 1899. New York: Modern Library, 2003. 46. Indeed Locke's opening to The New Negro parallels Griggs's own comments almost down to the structure and wording Griggs used in Imperium, as Locke draws a line from the passive and performative slave to the robust and self-assured "negro" 
Imperio reveals the novel to be a visionary text, well ahead of its time, but for this reason (and many others) the novel was not a run-away success. Griggs had chosen to print and peddle the book himself, focusing his efforts exclusively on reaching a black audience who he insisted "must rally around the printed page." ${ }^{, 59}$ Much to Griggs's dismay, black readers did not embrace the text, his publishing method did not allow for a wide distribution, and certainly its dramatic tale of political intrigue, racial violence, and black nationalism did not at all appeal to to white audiences. But just as its chapter 16 was titled "Unwritten History," so too was Griggs setting down a portrait of impassioned black strivings for equality at the turn of the century-efforts that combined the sacred and secular, the true spirit of Christianity with the decidedly un-Christian American racial system.

Truly, Griggs structures the novel in a way that identifies and lays bare the practice of racial injustice at nearly every strata of society. In its plot, Imperium in Imperio follows the darkskinned Belton Piedmont and his mulatto counterpart Bernard Belgrave from their early schoolhouse days through to adulthood and then into their turbulent public careers as activists for race reform. Belton and Bernard experience race in quite different ways throughout the course of the novel—sometimes due to covert, politicized schemes, but other times simply because Belton's skin is much darker than Bernard's. In the end, the two take leadership in a secret black

of the new era. Locke writes, "Uncle Tom and Sambo have passed on... the popular melodrama has about played itself out, and it is time to scrap the fictions, garret the bogeys, and settle down to a realistic facing of facts. [...] If ever it was warrantable to regard and treat the Negro en masse it is becoming with every day less possible, more unjust and more ridiculous" (5-6). See Alain L. Locke, The New Negro. New York: Touchstone, 1925. For his part, Charles Chesnutt also declared a similar sea-change in 1901, when he wrote, "Tradition... made the negro a slave, an underling, existing by favor and not by right, his place the lowest in the social scale. ... The old order has passed away, but these opinions, deeply implanted in the consciousness of two races, still persist" (5). See Charles Chesnutt, "Charles W. Chesnutt's Own View of His Story The Marrow of Tradition. Cleveland World. 20 Oct. 1901.

59 Griggs, Life's Demands; or, According to Law. Memphis, TN: National Public Welfare League, 1916. 33. In the introduction to Jim Crow, Literature, and Sutton E. Griggs, the editors also discuss other potential catalysts for Griggs's novel, including a pitched exchange he had with John Mitchell Jr., the editor of the Richmond Planet and the lynching of a black postmaster in South Carolina, Postmaster Frazier Baker (Chakkalakal and Warren, "Intro" 4-6). 
society in Texas - the Imperium — and, as with most tales of parallel heroes, only one person's vision can stand. Belton refuses to follow Bernard's radical, militant approach and, as a result, is executed as a traitor. Along the way, there is an attempted lynching, a suicide, numerous instances of public racial discrimination and violence, educational inequity, destruction of the black family, and religious indifference to racial injustice. It is a fast-moving, slim novel that refuses to rely on tidy distinctions between good and evil, nor does it culminate in a clear triumph of the revolutionary black separatist. In the end Griggs's tale resists a moralistic conclusion and succeeds in asking more questions about race reform than it answers-a historically appropriate approach for an issue that is still contentious and unsettled.

Most often it is the novel's ambivalent message and nearly cryptic ending that has frustrated scholars, leading them to demand something Griggs never promised: certainty. Literary critics have confidently labeled Imperium a "militant" novel, as a work of "black near futurist fiction," and even as an example of Griggs's "ideological contradictions" and "vacillation between one pole which is militant and fantastic and another pole which is realistic and accommodationist. ${ }^{, 60}$ But each of these readings cast Griggs as anomalous by decontextualizing his tale of racial tension. Rather, I submit that we do better to consider Griggs's novel on his own terms and in his own time, as do the scholars who have referred to him as a "novelist of the New Negro" and a "revolutionary" deeply imbued with the debates of his day. ${ }^{61}$ The truth is Griggs never promises a resolution, as indicated by his decision to frame

60 See Gloster, 337; and Kali Tal, “This Just Kills Me.” Social Text 20.2 (Summer 2002):65-91. 76.; Bone, 34. 61 See Gloster, 335; Roger Whitlow, "The Revolutionary Black Novels of Martin R. Delany and Sutton Griggs." MELUS 5.3 (Autumn 1978):26-36. Gloster's examination of Griggs places the minister-writer in context with other writers of his day who used the pen explicitly to respond to white supremacists like Thomas Nelson Page and Thomas Dixon, Jr. Further, while Gloster's language is, at times, dated, he rightly understands the value of Griggs's novels, including Imperium in Imperio, which he says, "exhibits the racial outlook that produced the National Association for the Advancement of Colored People and other organizations striving for the full participation of the Negro in American democracy" (338). 
the novel with an unreliable narrator. Much like the narrator in Twain's self-reflexive and evasive opening to Huckleberry Finn ("Mark Twain... told the truth, mainly") and Melville's enigmatic narrator in Moby Dick (“Call me Ishmael”), Griggs opens his novel by speaking through Bearl Trout whose first line is, "I am a traitor," and whose last line, closing the novel, is expressed in the form of a question: "When will all races and classes of men learn that men made in the image of God will not be the slaves of another image?" ${ }^{62}$ For Griggs, this uncertainty was the reality of his time, and chaos, violence, and betrayal threatened black Americans at every turn. When he read copies of the Baltimore Afro-American or the Richmond Times, Griggs saw accounts of recent lynchings and mob violence targeting black residents; at Baptist conventions he fought current restrictions on black authors, black ministers, black religious and educational organizations; and in his daily life he suffered the indignity of separate public transit accommodations for black and white citizens, observed discrimination in houses of worship, and witnessed the circumvention of voting rights for African Americans. ${ }^{63}$ In other words, social order as Griggs understood it through Jefferson and Jesus, was inverted in American society. So in this environment, when Bearl Trout declares, "I am a traitor" this label connotes something different entirely, as he goes on, in the very next page to say, "While I acknowledge that I am a traitor, I also pronounce myself a patriot... [and] the outstretched arms of God will receive my spirit as a token of approval for what I have done." ${ }^{64}$ In other words, to be traitorous in this environment is to be accepted by God, and to be a patriot means to go against the established order and its unjust and racist pronouncements. There is no satisfactory resolution, Griggs says,

62 Griggs, Imperium, 5 and 177.

63 Through his various works of fiction and non-fiction Griggs comments on each one of these forms of racial discrimination. For a brief note on Griggs's activism, see Harvey 234, and for a more extensive discussion, see Lester C. Lamon, Black Tennesseans, 1900-1930. Knoxville, TN: University of Tennessee, 1977. 12-14 and 2027.

64 Griggs, Imperium, 6. 
because in this setting such resolution is impossible.

The characters of Belton and Bernard, then, provide sharp insight into the twoness of Griggs's own thinking regarding racial activism, and it is important to note that this dualism existed in Griggs throughout his life. As Chakkalakal and Warren write, "Griggs was remarkably consistent in his political opinions. ${ }^{, 65}$ On one hand, Griggs resembled Bernard—a fiery opponent to white supremacist policies and an active social reformer. Not only did Griggs espouse separatist activity in the national black Baptist convention, he also organized a boycott of segregated streetcars in Nashville, gave public speeches and wrote newspaper columns condemning police brutality against blacks, and he spent decades organizing black "welfare leagues," institutional churches, and "social reconstruction associations." ${ }^{.66}$ But on the other hand, Griggs resembled Belton, who saw the value of blacks working in cooperation with whites. Griggs wrote of "combinations" and endorsed an individualized approach to working with progressively-minded whites in Imperium, and implored African Americans to cooperate with white reformers by living out the principles of "collective efficiency" or "social efficiency"terms he used interchangeably in the early twentieth century. Indeed, in his public career Griggs regularly called for both intraracial and interracial efforts on behalf of social progress and he was careful to distinguish between working with whites and accepting white supremacist policies. The two were not the same for Griggs, and from the beginning of his ministry, he insisted that African Americans needed the aid of white Americans, financially, politically, and spiritually to bring about a better society for all. These approaches, then, trace back to Imperium, with Griggs presenting the dilemma and the possibilities as represented by Bernard and Belton, not designing 
one grand solution.

If Griggs's novel is prescriptive in any way, it is the way in which his theology, centered on the person of Christ and expressed through Belton's spiritual development, provides a scaffold for race reform in Imperium and beyond. Belton learns early in the novel to insist on the chosenness of his race and to value the "suffering Savior" as a model, rejecting blind vengeance and violence alike. For this reason I reject the assertions prevalent among scholars that Imperium was written during Griggs's "militant" period or that he uses the novel to advocate a breakaway nation of black believers. ${ }^{67}$ Neither of these readings resonates with Griggs's activism, nor do they align with his lifelong opposition to emigration and northern migration. ${ }^{68}$ Instead the novel acts as a rallying cry for black Americans - to force them to confront, as Belton does, just "what kind of country [they] had entered" in the late nineteenth century, and to consider how best to bring forth the New Negro in a way that "the outstretched arms of God [would] receive" them and express "approval of what [they had] done. ${ }^{, 69}$ Readers were not meant to side with Bernard or Belton, exclusively. Instead, Griggs wanted to expose the horrors of American racial policies in a way that would spur other black Americans to action, even while cautioning them of what happens when a quest for justice turns into a pursuit of unchecked vengeance. Certainly Imperium is not the typical religious novel of its time: it resists sentimental accounts of spirituality, it contains few direct quotes from scripture, and its depictions of ministers and

67 As Coleman notes, Griggs "believed militant revolt was implausible," and he never espoused government takeover or a collective breakaway (107). And while there are valuable aspects of Caroline Levander's article, "Sutton Griggs and the Borderlands of Empire," I find that her argument ultimately rests on a faulty assumption - that the novel "helps Griggs to reformulate the terms in which an urgent national question is posed - the question of where free blacks should call home" (61). For Griggs there was never a doubt that black Americans should remain loyal to the United States and to reside in and reclaim the South, "put[ting] country first, race next, and self last" (Paths of Progress 27).

68 Coleman writes, "Griggs did not favor emigration as a response because he felt that the United States belonged to blacks as much as it did to anyone. Likewise, Griggs felt that the South was something of a natural home for blacks and that northern cities presented untold dangers. A mass migration to the North, in his opinion, was tantamount to moving the problems from one region to another" (107).

69 Griggs, Imperium, 99 and 6. 
African-American Christianity are often satirical. But by the novel's end Griggs hoped his "teaching had the desired effect upon the white man" and "would also be powerful enough to awaken the negro standing by his side., 70

To understand Belton's development into a Christ-like figure, we must first interrogate the ways that Griggs develops his image of "the suffering Savior." In the novel, Belton attends the fictional Stowe University, located in Nashville, and has a college career not unlike Griggs's own at a black Reconstruction-era institution in the South. Immediately Belton feels the enlarging possibilities of education, with a dedication toward his race and a frustration toward white southerners who "despised and fought the agencies that were training and inspiring the future leaders of the Negro race" and have yet to bring about the "New South." ${ }^{, 71}$ At Stowe, prejudice against the black instructors spurs Belton to lead a rebellion among the black students, and their protest in solidarity gains equal rights for the "colored teachers" who are finally permitted to each lunch with the white teachers. Griggs writes that this moment "was Belton's first taste of rebellion against the whites for the security of rights denied simply because of color." ${ }^{, 72}$ Already in this instance Belton is prophesied to be a kind of sacrifice, as the narrator looks to the future and cryptically states, "In after life he is the moving, controlling, guiding spirit in one [a rebellion] on a far larger scale; it need not come as a surprise. His teachers and school-mates predicted this of him." ${ }^{, 73}$ This foreshadows Belton's sacrificial death, of course, but Griggs's characterization of him as a "moving, controlling, guiding spirit" also echoes Jesus's own promise of the Holy Spirit, who would come following his death and lead his followers by 
"bring[ing] all things to [their] remembrance." 74

But Belton's most profound instruction on the social implications of Christianity comes through his interaction with Stowe University's (white) President Lovejoy. In two separate incidents, Belton is impressed by the self-renunciation required as a follower of Christ, such as in Dr. Lovejoy's Baccalaureate sermon, which Griggs is careful to note, "had much to do with Belton's subsequent career." ${ }^{, 75}$ Lovejoy states:

Young men, we shall soon push you forth into the midst of a turbulent world, to play such a part as the voice of God may assign you.... The part that you play, the character of your return journey... will depend largely upon how well you have learned the lesson of this text. Remember that the kingdom of God is within you. Do not go forth into the world to demand favors of the world, but go forth to give unto the world. Be strong in your own hearts. ${ }^{76}$

Lovejoy's sentiments could be read ironically, of course, as a reminder for the young black men not to expect too much from the world and to give of themselves, rather than working to take back rights denied them by a white supremacist culture. And certainly, Lovejoy goes on to emphasize this point by stating, "Think not of yourselves. Let your kingdom be within" and "take no thought to your own glory." ${ }^{, 77}$ Most strikingly he tells the men, "Be not a burrowing parasite, feasting off of the world's raw blood. Let the world draw life from you. ${ }^{, 78}$ But read correctly, in the broader context of Griggs's own actions and writings on social Christianity, this sermon actually underscores the novel's greatest argument to black believers: that the kingdom

74 Ibid, 47; and John 14.26, KJV.

75 Griggs, Imperium, 51.

76 Ibid, 49.

77 Ibid, 50.

78 Ibid. 
of God requires its followers to put aside individual gain, and the kingdom of God offers to followers the transformative power of Christ's indwelling. For a race relegated to the margins, then, membership in God's kingdom meant belonging and self-value. It is this concept of the kingdom that later empowers Belton to challenge Bernard's militant vision for the Imperium, and Belton aligns himself typologically with biblical leaders like David and Abraham in part because they are all equal parts of God's kingdom, striving to live faithfully "according to the little light that struggled through the clouds to reach" them. ${ }^{79}$

As Griggs wrote Imperium he was certainly concerned about the larger kingdom of Christianity—both wrestling with prejudice in the Baptist camp as well as legalized discrimination from Christians in South who believed a man's worth could be determined by the color of his skin. So it is not surprising that he wanted to speak directly to his fellow black Americans through he novel. Through Belton's discoveries, Griggs reminds fellow black Christians that, as Lovejoy told the students, they "are highly favored of God" and chosen members of his kingdom, who possessed within them all the power they needed to be the next "commanders" of their race ${ }^{80}$ From the earliest part of his career to the end, Griggs was very much concerned with the implications of the kingdom of God in a practical, earthly, and transformative sense. As late as 1921, Griggs argued with a typological view of sacred history, stating that "the need of the hour" is for "an Esther to plead the successfully the cause of millions. ${ }^{\prime 81}$ And he likened the cause of black equality to the building of Christ's kingdom, writing that, "In the end, the policy of appealing to the best that there is in men must win, if the

79 Griggs, Imperium, 154.

80 Ibid.

81 Sutton E. Griggs, Light on Racial Issues. Memphis, TN: National Public Welfare League, 1921. 37. 
teachings of Jesus are to be the hope of mankind." 82 Further, in his own ministry, this concept of God's kingdom led Griggs to transform Tabernacle Baptist Church in Memphis (as well as many other churches in the area) into an institutional church, and there he also held a "Kingdom Builders" class that met on Sunday afternoons. ${ }^{83}$

Finally, it is in another experience involving Lovejoy that Belton is acquainted with the notion of the "suffering Savior" on whom the "kingdom" is built. When Belton is the target of a cruel prank by his roommate — a gag that embarrasses him and taints his valedictory address— Belton seeks revenge and "vows to kill the rascal that played that trick on him." ${ }^{84}$ But Lovejoy finds Belton the next day and reminds him "what an unholy passion revenge was" and that "such a passion would mar any life that yielded to it." ${ }^{, 85}$ In his conversation, Lovejoy is said to figuratively draw "a picture of the suffering Savior, crying out between darting pains the words of the sentence, the most sublime ever uttered: 'Lord forgive them for they know not what they do. ${ }^{, 86}$ In response, Belton "was melted to tears of repentance for his unholy passion." ${ }^{87}$ And the reader is met with foreshadowing for Belton's career as a race leader: "It was a narrow escape for Belton, but he thanked God for the lesson, severe as it was, to the day of his death. The world will also see how much it owes to God for planting that lesson in Belton's heart." 88 As before, Lovejoy's words could be interpreted as placative and as a metaphor for a white culture that cajoled black Americans into submission, insisting they accept their fate as a mark of God's

82 Ibid, 42.

83 See Walker, 25-30. Griggs also penned and self-published a text titled Kingdom Builder's Manual, which he attempted to have the Sunday School Board of the National Baptist Convention accept as a textbook. The plans never materialized. See Sutton E. Griggs, Kingdom Builder's Manual, Companion Book to Guide to Racial Greatness. Memphis, TN: National Public Welfare League, 1924.

84 Ibid, 55.

85 Ibid, 56.

86 Ibid.

87 Ibid.

88 Ibid. 
chosen race. But for the progressive Griggs, this image of the "suffering Savior" certainly means something more - a source of empowerment, not an acceptance of second-class citizenship, and a sacred model through which to question the militant practices of race reformers who called for violence and retribution. "Our call here for the sake of the Negro race is not unto a field of blood," Griggs wrote in Life's Demands. "No one is asked to die for his race. But what is asked is that men shall live for their race, that they shall live that they can and will work together faithfully, successfully, forever, transmitting collective power from one generation to another." ${ }^{, 89}$ Neither is this image of the suffering Savior an anomaly for its time, as it adheres to a larger conception of black theology at the turn of the century. As discussed throughout this study, depictions of Jesus as "despised and rejected of men" often took on a liberatory message when applied to African Americans marginalization. Indeed, as I argue in chapter two, even bestselling author Charles Sheldon argued that to follow in Christ steps required self-sacrifice, and Sheldon's concept of “discipleship" seems to resemble Griggs's own position of "selfrenunciation," which he detailed in non-fiction works later in his career. But Griggs's specific discussion of the suffering Savior in Imperium in Imperio also bears a striking resemblance to an 1898 editorial column in the Baltimore Afro-American titled, "A Suffering Savior and a Suffering Race." In it the unnamed author connects Christ's suffering to contemporary injustices endured by black Americans and urges, "Surely the example of the Savior ought to be our inspiration! He can not, He will not forget his suffering people." 90 The writer goes on to connect suffering with "chosenness," stating, "Evidently, God has called us, as a race, to peculiarly share in His sufferings, that the endurance, fortitude, courage, and complete resignation to his blessed will... may fit us to illustrate in our own lives, the truest, deepest, and noblest spiritual 
expressions of the Gospel of Love indicated in the Sermon on the Mount."91 Certainly this aligns with Griggs's insistence that injustice should lead black Christians back to "the teachings of Jesus" as "the hope of mankind." 92

Yet while the downtrodden may find refinement through hardship, neither Griggs nor the author of "A Suffering Savior and a Suffering Race" suggest a placid acceptance of discrimination. Rather, the columnist goes on to cite various "sorrows" endured by African Americans, noting, "We do not receive anything like the treatment we have a right to expect," and naming "white men" as the source of this injustice that must be overturned. ${ }^{93}$ The writer then closes by quoting from I Peter 2, writing in part, "Christ also suffered for us, leaving us an Example, that ye should follow his steps: who did no sin, neither was guile found in his mouth; who when he was reviled, reviled not again: when he suffered, he threatened not; but committed himself to him that judgeth righteously." 94 This is the "suffering Savior" of which Lovejoy speaks, and the image has lasting implications for Belton's eventual role in the plot of Imperium, such as his refusal to fight discrimination with violence and his refusal to respond with "guile" or "threats" as he goes to his execution. And finally, as we will see later in this chapter, this image outlines Griggs's lifelong principle of self-renunciation, a doctrine that pervaded this fiction, non-fiction, and racial activism.

In many ways the entire novel sets the stage for the final show down at the Imperium, and in subtle and non-so-subtle ways Griggs describes the shaping influences on Belton's and Bernard's thinking. As I will demonstrate, it is the character of Belton-through his experiences and eventual stance against militant action — that more reflects Griggs's own perspective. For

91 Ibid.

92 Griggs, Light, 42.

93 "A Suffering Savior," 2.

94 Ibid and I Peter 2.21, KJV. 
Belton's part, he encounters white men who both help him and seek to harm him, and the experiences have lasting implications for his philosophy and later actions. In one instance, prior to going to Stowe, Belton befriends a newspaper editor named V. M. King who is described as "ultraliberal" and who writes scathing editorials "opposed to the practice, almost universal in the South, of cheating the negro out of his right to vote" believing it was "unjust to the negro and fatal to the morals of the whites. ${ }^{.95}$ King predicts that the younger generation of black Americans would not waste their time "looking back" like those who remembered the days of slavery and would instead demand the rights guaranteed them by God and the Constitution. ${ }^{96}$ To endorse a member of this new generation, he funds Belton's college expenses; in response, he only asks that Belton remember "there are two widely separated classes of us, and there is a good side to the character of the worst class. Always seek for and appeal to that side of their nature. ${ }^{997}$ Belton agrees, vowing "to never class all white men together... and to never regard any class as totally depraved." ${ }^{, 8}$ Again, the narrator reminds us of this scene's importance, remarking, "This is one of the keys to his future life. Remember it." ${ }^{.99}$

In another instance Belton becomes the victim of virulent racism and is nearly lynched by a mob seeking vengeance. The incident happens when Belton journeys by train to Louisiana to accept a position as president to an all-black college. Griggs carefully reminds the reader that, "separate coaches for colored and white people had not been enacted by any of the Southern States," but that "in some of them the whites had an unwritten but inexorable law, to the effect that no Negro should be allowed to ride in a first-class coach. Louisiana was one of those states,

95 Griggs, Imperium, 33.

96 Ibid, 33-34.

97 Ibid, 36-37.

98 Ibid.

99 Ibid. 
but Belton did not know this." ${ }^{100}$ Belton boards the first class car, and is soon met by a group of angry white men who order him to vacate the car, stating "we are our own authority." ${ }^{101}$ When he refuses they throw him from the moving train. Later, Belton is forcibly removed from a restaurant when the clerk refuses him a table, deeming him a "high-toned nigger" who wants to "sit down and eat like white people." 102 With each of these moments, Griggs sets paints stark and faithful images of the South as he knew it, underscoring the ways in which white supremacist rule polluted the nation and endangered its black citizens who were entitled to full rights by the Constitution. This is the chaos that surrounded Griggs - a South where black Americans were not offered federal protection, where vigilante violence was the law, and where even an educated, respectable, and God-fearing black man like Belton was despised.

It is fitting, coming from Griggs, that Belton is finally caught and (nearly) lynched for having "the gall to enter a white church" and taking a "seat down stairs with the white folks."103 As Belton is about to be hanged, he "felt somehow that God was at work to deliver him" and therefore "made no resistance, having unshaken faith in God." ${ }^{\text {"104 }} \mathrm{He}$ does survive, but in a disturbing twist he finds himself on an examination table at the village doctor's office, as Dr. Zackland had intervened with the mob and secured Belton as his next cadaver. ${ }^{105}$ Belton again escapes with his life, this time by killing Zackland. He is later arrested for the murder and, with this development, Griggs reunites the two schoolmates, as Belton now depends on both Bernard's position as a lawyer and his oratorical skill to secure an acquittal. The case goes all the

100 Ibid, 96-97.

101 Ibid, 97.

102 Ibid, 99.

103 Ibid, 104.

104 Ibid, 105.

105 Knadler helpfully points out that the name Dr. Zackland "symbolically... stands in for a typological imperial U.S. villainy, since the 'zack' element suggests an elision of Zachary Taylor, the military hero of an earlier U.S. expansion into Texas to create a separatist state" (689-690). 
way to the Supreme Court where Bernard "made the speech of his life" by heralding of Belton's "noble life, his unassuming ways, his pure Christianity."106 Belton is released and once again the narrator interprets the event for the reader: "Thus ended the tragic experience that burned all the remaining dross of Belton's nature and prepared him for the even more terrible ordeal to follow.",107

More than establishing the need for racial justice in southern society, Belton's ordeal affirms that he is a man chosen by God. When Griggs notes that the attempted lynching "burned all the remaining dross of Belton's nature," he echoes several Old Testament passages that speak of the "refining" process through which God brings about righteousness for his purposes. In Isaiah God tells Israel he will purge away thy dross" and that Zion will be "redeemed with judgment, and her converts with righteousness."108 Similar promises of judgment and subsequent redemption appear in Ezekiel and Jeremiah. ${ }^{109}$ Then, in Malachi 3 the Messiah is prophesied to be one who will "sit like a refiner of silver, burning away the dross" and sit in defense of those who are oppressed and turned aside as outcasts. ${ }^{110}$ In other words, to be used of God requires suffering, deliverance and, thereby, purification to redeem and bring the believer in line with God's will. For Belton, we are led to believe that his life is no longer his own after he has been spared from death, and the "dross" of which is purged is his own self-interest - an essential transformation for the New Negro to emerge. Indeed, this complements Finnie Coleman's estimation of Imperium when she writes, "Griggs's work went beyond merely heralding the coming of this new generation; he attempts to shape the character and direction of that group as

106 Griggs, Imperium, 109.

107 Ibid.

108 Isaiah 1.25 and $1.27, \mathrm{KJV}$.

109 Ezekiel 22.18-19 and 24.11; Jeremiah 6.29 and 23.29. Other similar passages appear in the "wisdom literature" sections of the Old Testament, including Psalms 119.119; Proverbs 25.4 and 26.23.

110 Malachi 3.3 and 3.5 
well" to draw "distinctions between the old ways of being and the new." "111 Or, as Griggs later wrote in Light on Racial Issues, "Men cannot have double natures. We cannot have one character in religious life and another in civil life. The essential character of the soul of a race will manifest itself in whatever it takes part."112 In the case of Belton, his "refined" character leads him to live for a purpose greater than his own life, and the next time we meet with him in the novel, he has established the Imperium for the development and improvement of his race.

Regarding Bernard's portion of the narrative, Griggs also characterizes him as one who attains great heights in his education and career, but due to racism suffers great hardship. In many ways he resembles one of DuBois's "Talented Tenth," as he is raised in an educated, wealthy home, is named valedictorian of his graduating class at Harvard, and goes on to study law and rise to political fame. But while members of the black community hail him as "the coming Moses," Griggs hints that Bernard will never succeed in such a sacred endeavor. ${ }^{113}$ Instead Griggs points out Bernard's motives for his career, stating that he "sacrifice[d] everything to the goddess of fame.... He decided to become the obedient servant of the people that he might thus make all the people his servants." 114 But at the "acme of his fame" when he "had succeeded in becoming the most noted negro of his day," Bernard's life, too, is marred by the pain of his fiancée's suicide. ${ }^{115}$ Viola had been led astray by contemporary theorists who argued "the intermingling of the races" would sap "the vitality of the Negro race" leading to their slow but sure extermination; so rather than "intermingle" with mulatto Bernard, she ends her life. ${ }^{116}$ Here, as elsewhere in Griggs's catalog, the mulatto character is punished essentially for

111 Coleman, 82.

112 Griggs, Light, 13.

113 Griggs, Imperium, 77.

114 Ibid, 68.

115 Ibid, 110.

116 Ibid, 118. 
not being black enough, and as Stephen Knadler reflects, the character of Viola "recalls the tragic mulatta of racial melodrama who commits suicide when she cannot pass as white. ${ }^{" 117} \mathrm{Her}$ tragic death spurs Bernard to action, a catalyst that eventually leads him to embrace a violent militancy in defense of African-American identity. Bernard vows, "These races, whose union has been fraught with every curse known to heaven and hell, must separate." ${ }^{118}$ That same day, he receives a letter from Belmont, requesting that he come to Waco, Texas, where Belton has founded the Imperium.

As its name suggests, the "Imperium in Imperio" is a state within a state, a literal manifestation of the African-American identity that is wholly within and yet wholly apart from the United States. Belton explains to Bernard that it is "another government, complete in every detail, exercising the sovereign right of life and death over its subjects... organized and maintained within the United States for many years." ${ }^{, 19}$ With seven million two hundred and fifty thousand, the separatist "state" possesses its own Constitution, Central Government, Congress, and court system, with a staggering $\$ 850,000,000$ at its disposal. Before revealing details about the Imperium, Belton tests Bernard's loyalty in a jarring scene where Bernard believes he will be executed, then falls through a trapped door-not to his death, but into the main chamber of the Imperium's Congress. Of course this moment mimics Belton's own "fall" and subsequent "rebirth" during the Louisiana lynching; and it foreshadows Belton's eventual execution as he maintains fidelity to his own principles.

Of course the Imperium is a failure, but what is important for Griggs's vision is not so much that it fails as why. The last few chapters of the novel, in fact, are retellings of Belton's and

117 Knadler, 692.

118 Griggs, Imperium, 120. Emphasis added.

119 Ibid, 129. 
Bernard's competing visions of history, offered in the form of public addresses to the Imperium's governing assembly. The "state within a state" has come to a moment of decision and must chart a path forward, either as separatists that violently challenge the U.S. government or as a group of determined and competent "New Negros" who exercise the right to the ballot and the power of the pen to "pull the veil from before the eyes of the Anglo-Saxon." ${ }^{120}$ The orations reveal dramatically different interpretations of how African-American history should be "read," and therefore submit competing images of how the "New Negro" should engage with these histories and chart a path forward. Here Griggs's principle of "collective efficiency" is on display through Belton. Griggs indicates that violent and permanent separation of the races (what Bernard advocates) is an untenable and, indeed, unchristian solution to racial injustice. In its place he submits Belton's vision of interracial cooperation, just as Griggs would later suggest in Light on Racial Issues that black Americans should "meet half-way all who are in any way seeking to make things better for our people." ${ }^{121}$ For such a nuanced reading of Imperium in Imperio's conclusion, then, it is necessary to break away from the novel and explore Griggs's Christian-inspired social theory of racial uplift that he called "collective efficiency." Not only does this philosophy interpret the ending of Imperium, but it also helps to restore wholeness to Griggs's vision for African-American improvement. "Collective efficiency" reveals the manner in which Griggs translated his idealism into a pragmatism he believed was best suited to the era. It was an approach to which he devoted all of his writings and most of his life.

\section{Griggs's “One Solution,” or; Racial Solidarity through Cooperation}

In his 1921 pamphlet Light on Racial Issues, Griggs devotes a section to "The Christian

120 Ibid, 163.

121 Griggs, Light, 19. 
Method of Discussing Racial Issues," in which he states, "It is not enough merely to have a burning zeal for a righteous outcome of things. Zeal must be accompanied by knowledge of the right methods to be employed to reach the desired ends." ${ }^{122}$ To illustrate this point as any good minister would, Griggs reminds readers of a zealous apostle from the New Testament: Peter was thoroughly convinced of the righteousness of his Master's cause, and was full of zeal. But when he cut off the ear of the servant of the high priest, his Master rebuked him. The Master had a far better way in which Peter could serve the cause. The pentecostal sermon which Peter preached was a far greater weapon of warfare than the sword which was ordered back into its scabbard. ${ }^{123}$

The anecdote provides remarkable insight into Griggs's philosophy of racial improvement: first, emotion and enthusiasm, while useful, had to be tempered with a balanced and pragmatic approach. Second, while humans often act out according to their own understanding, God is himself orchestrating history for a higher purpose (just as Griggs insisted that sacred history was the backdrop of black strivings). And finally, the just should fight the good fight by employing the immense power of language, rather than turning to violence and warfare. To Griggs's critics, these assertions amounted to an "accommodationist" approach, and some even sharply denounced him as "the apostle of the white race." ${ }^{124}$ But he believed his principle of "collective efficiency" provided a practical way of implementing the "zeal" of Peter in a way truly situated to the dawn of the twentieth century. The approach was a social expression of Christian principles, Griggs insisted, and would preserve the black race by finally

122 Ibid, 47.

123 Ibid.

124 Coleman, 27. 
lifting them to a place of respect and equality in American society. ${ }^{125}$

For this reason, his "collective efficiency" or "social efficiency" (used interchangeably) called for a tempering of the emotions through a denial of the self, it underscored a sense of divine history through cooperation and the greater good of Christ's teachings, and it promoted the power of the written and spoken word, through which the black cause could be articulated. It is crucial to note that Griggs's endorsement of these ideas was not confined to merely one or two obscure publications, nor was collective efficiency a footnote to his activism. Instead, to use his words, "the cooperative spirit" is an exhortation that pervades his writing — an undeniable and essential part of his thinking that guided his actions, public and private, throughout his career. ${ }^{126}$ For example, when Griggs skirmished with national Baptist leaders over educational funding for black colleges, as noted earlier, he did endorse a breakaway group that was separate from the main Texas convention. But as Paul Harvey notes, these "separatists" also cooperated with and accepted donations from white Baptists, the only stipulation being that use of funds "would not be contingent on specific policies." ${ }^{127}$ At this same time Griggs also debated publicly with John Mitchell Jr., editor of the Richmond Planet, defending the Baptist church and arguing that the denomination must not divide along racial lines. Mitchell, a member of the A.M.E. church, hailed his denomination as a purer "Negro religious organization," but Griggs protested, saying that the Baptist church was a fitting "forum for lively political debate" regarding black rights. ${ }^{128}$ In other words, as Chakkalakal and Warren state, "Griggs was remarkably consistent in his

125 Coleman, 27.

126 Griggs, Light, 58.

127 Harvey, 70.

128 See Chakkalakal and Warren, 6. This section of their "Introduction" describes this exchange between Griggs and Mitchell in detail, and the writers assert — unlike most Griggs scholars - that, "Though several critics have argued that a shift or 'metamorphosis' from 'Black Radical to Conservative,' to borrow from the title of Randolph Meade Walker's 1990 study... Griggs's early confrontation with Mitchell suggests the opposite" ("Introduction," 6). 
political opinions. Against the rising tide of antiblack sentiment during the period, Griggs believed that cooperation between the races remained the best and most effective policy." ${ }^{, 129}$ For this reason, Griggs's theory of racial uplift-“collective efficiency"- can be found throughout his oeuvre and serves as a lens through which to view all of his writing, including Imperium in Imperio.

Essentially, the principle of collective efficiency had one main teaching: that each member must privilege the welfare of the group over individual concerns, even to the point of self-denial. In Light on Racial Issues Griggs outlines this strategy for "racial success," condemning individualism and hailing cooperation for the good of the race. "Individualism," Griggs says, seeks "self-aggrandizement" and elevates "personal interest over the interests of the group," which can never bring about the "spirit of reform" American society needed. ${ }^{130}$ Elsewhere, in Life's Demands, Griggs writes that an "individual that has personal success and draws off from his race, content with what he has accomplished personally, sins against himself, for the suspicion will abide that he has not wholly escaped the taint regarded as belonging to his race. ${ }^{, 131}$ Instead, for black Americans on the margins of society, individual success must always be viewed in light of the community's welfare. "The great, the crying, the overwhelming need," Griggs wrote, is for "racial success." ${ }^{132}$ For this reason, he asserts without deviation, that, "each member of a race" must "be deeply concerned, not only about his own personal welfare, but about that of his race as well." 133 Such privileging of the good of the race may necessitate "selfrenunciation," which Griggs believed had divine sanction in the person of Christ; after all,

129 Ibid.

130 Griggs, Light, 58-59.

131 Griggs, Life's Demands, 30.

132 Ibid. Emphasis added.

133 Ibid. 
selflessness was the spirit of the "suffering Savior" he depicts in Imperium and "the core of the Christian religion... [which] is likewise the foundation of society."

Christ's teachings also emphasized the transformative power of self-denial—-for an individual believer and for the greater good. At a 1923 gathering of the National Baptist Convention, Griggs urged his fellow African Americans believers to "put country first, race next and self last, remembering that 'he that seeketh to save his life shall lose it, but he that loseth his life for my sake shall find it again.",135 This of course charts individual strivings against a broader sacred history and unites social transformation with spiritual renewal. In fact, it was Griggs's emphasis on "self-renunciation" and "racial success" that led to the establishment of multiple institutional churches in Tennessee and Missouri. In 1925 the American Woodmanone of the strongest black fraternal organizations in America—voted to "adopt the philosophy of racial advancement as worked out by Dr. Sutton E. Griggs in his books 'Guide to Racial Greatness' and 'Stepping Stones to Higher Things." "136 That same year, black clergy in St. Louis adopted Griggs's philosophy of collective efficiency "for the reconstruction of the race," and in the next few years Griggs was invited to congregations in Knoxville, Tennessee, and Springfield, Missouri, to share strategies for implementing collective efficiency. ${ }^{137}$

While Griggs denounced individualism and encouraged self-denial, he also heralded the controversial value of cooperation in both intraracial and interracial efforts. In fact, nowhere does he write about collective efficiency without mentioning cooperation by name, in the very same work. The reformer believed that "military, legislative, executive, and judicial departments

134 Griggs, Cooperative Natures and Social Education: A Philosophy of Civic Life. Memphis, TN: National Public Welfare League, 1929. 85.

135 Griggs qtd. in Walker, 63. Here Griggs paraphrases a sentiment found multiple places in the New Testament, including Matthew 16.25 and 10.39, Mark 8.35, Luke 9.24 and 17.33, and John 12.25.

136 Qtd. in Walker, 29-30.

137 Ibid. 
of the national government" had failed African Americans, so that blacks could no longer expect outside influences to establish and protect their equality. Instead, ever the pragmatist, Griggs argued, "the logic of the situation demands that the Negroes of America have as their policy the cultivation of a friendly relationship with their white neighbors." ${ }^{\prime 138}$ It was a teaching he lived himself, as he worked with white and black ecumenical organizations as well as white and black public reformers. This focus on cooperation also aligns Griggs with Belton Piedmont, with Booker T. Washington, and with many other writers, leaders, and thinkers who have been labeled "accommodationist." And yet, when one explores the nuance and historical context of Griggs's principles, it is clear that such a label is inadequate, at best. Nowhere did Griggs endorse the notion of second-class citizenship for black Americans, nor did he feel they should play the role of servant or minstrel to white superiors. Instead, Griggs faced the fact that white Americans still had majority political power, had greater financial resources, held the greatest influence over social and cultural mores, and therefore could be valuable allies for the cause of black equality if the right method of "cultivation" was employed. In other words, Griggs insisted leaders modeled on Nehemiah and Esther could do more good for the race than violent or militant leaders who, like Peter, drew swords when they were surrounded by the opposition. ${ }^{139}$ Finally, Griggs believed the teachings of collective or social efficiency depended on a strong, persuasive racial literature and that the power of language was essential to the improvement of the race. In his non-fiction he outlines this most clearly in Life's Demands, writing, "Negro literature should be developed as a racial voice, with the power to reach the hearts of the white people. ... Let the entire race rally around the page." ${ }^{140}$ And in The One Great Question, he

138 Griggs, Life's Demands, 64. 139 See Griggs, Life's Demands, 66-68 and Light on Racial Issues, 37. 140 Ibid, 82-83. 
endorses using the "exponents of public sentiment in the country at large, the pulpit, the press, the platforms of political parties" to "set forth" the black cause "in calm but forcible language." ${ }^{141}$ Utilizing such avenues of debate and persuasion would strengthen the black community, Griggs asserts, while also "educating public opinion" across the color lines (and, in particular, white southerners, who Griggs insisted could be transformed into allies). Here Griggs mentions white and black leaders capable of providing a literary articulation of race reform to the American public, naming Edgar Gardner Murphy and W.H. Fleming among the "whites," and none other than W.E.B. DuBois from the black community. The significance of this should not be overlooked, for Griggs believed his concept of racial improvement not only promoted racial solidarity and a denial of individualism through the persuasive articulation of rights, but that it could span the efforts of Washington and DuBois for the collective good of all African Americans. ${ }^{142}$

Of course Griggs's theories take vivid form in the conclusion of Imperium in Imperio, as Bernard and Belton square off as race reformers with conflicting visions of the future. In light of collective efficiency, the novel's ending is no longer ambiguous, but decisive. Bernard is clearly a Peter figure who has "zeal" but no "knowledge of the right methods," and Belton, conversely, exemplifies the teachings of self-denial and cooperation. Certainly Griggs hoped to communication a transformative message through their fictional oratory, and it should be noted

141 Griggs, The One Great Question, 55-56.

142 It is important to note that Griggs $\mathrm{did}$, at various points in his career, endorse the race reform efforts of both DuBois and Washington; similarly, he also questioned their efforts at other points in his career. But it is not, as some Griggs scholars have argued, as simple as charting Griggs's early thinking along DuBoisian theories and grouping Griggs's later thinking in with Washington. Even in the first years of his public career, Griggs believed that interracial cooperation was essential to racial improvement for black Americans and, at the same time of his life he worked with DuBois as part of the Niagara Movement. Ultimately, Griggs's theories were both/and approaches to reform and, as indicated in the opening of this chapter, his writings should challenge our oftenneat categorization of turn-of-the-century race reform efforts along the DuBois-Washington binary. For more on Griggs's work with DuBois and the Niagara Movement, see John Ernest, "Harnessing the Niagara." 
this is the only time in the novel that readers are given the entire "transcript" of their speeches. Throughout the book we are told the two are accomplished orators, such as when Bernard defends Belton before the Supreme Court, and they are described as "oratorical gladiators" when they give addresses to a mixed race audience in school. ${ }^{143}$ But to these events we, as readers, are mere secondhand witnesses; Griggs never provides texts of speeches until this final exchange. There, for multiple chapters, Griggs lays out their addresses before the Imperium's governing body.

The arguments Belton and Bernard present are too extensive to treat in exacting detail here, but it is important to understand the ways in which Belton exemplifies the principles of collective efficiency and Bernard violates such teachings. In a spirited and militant speech Bernard methodically implicates every aspect of American culture that has wronged the "Negro"- from inadequate education and a denial of political representation to hypocrisy regarding Christian churches, a racist justice system, and the nation's denial of Jeffersonian ideals to black citizens. Bernard also generalizes the character of all "Anglo-Saxons" by saying "they have apparently chosen our race as an empire," and he thereby closes the door to any consideration of interracial cooperation. ${ }^{144}$ In regard to Bernard's ethos, Griggs says, "The whole man was to speak that day. And he spoke. We can give you his words, but not his speech." ${ }^{145}$ It is no surprise, then, when readers learn that Bernard's oratory has such persuasive power over his audience, that another member of the Imperium rises and declares "I am for war!" to which others responds by chanting "War! War! War!"146 Once again this replicates Griggs's discussion of "zeal" absent "right methods," and sets the stage for Belton who opposes the rising tide of

143 Griggs, Imperium, 27.

144 Ibid, 147.

145 Ibid, 139.

146 Ibid, $151-152$. 
bloodthirsty separatism. Just as a vote is about to be taken, regarding Bernard's resolution of war, Belton objects that he is "not ready," and embarks on his own address to the Imperium. ${ }^{147}$ Griggs writes, "We are now about to record one of the most remarkable feats of oratory known to history." 148

Belton's speech, then, represents both the potential and the fraught positionality of Griggs's collective efficiency. He appeals to the "holy mission" of the Imperium to regain the "stolen rights, given to us by nature and nature's God," and in doing so, he insists on a more nuanced understanding of African-American history in the South. ${ }^{149}$ Belton argues that "in judging a people we must judge them according to the age in which they lived, and the influence that surrounded them"- an allusion to the promise he made to Mr. King many years earlier. ${ }^{150}$ Then he vowed to remember there are "two widely separated classes" of white Americans, something Bernard was not prepared or willing to admit in his "zeal" for action. ${ }^{151}$ In this way, Belton goes on to detail ways in which slavery had an enriching influence on blacks-a section of his speech that is surely perplexing, if not disturbing, to modern readers. Specifically, he cites how African Americans have benefited from "knowledge of the English language, and a conception of the one true God and his Christ." ${ }^{152}$ In regard to turn-of-the-century concerns, Belton acknowledges inequity and prejudice in employment opportunities, civil rights, law, the court system, and political representation. But in response to these injustices, Belton's argument is a near copy of Griggs's own, as he insists black Americans can once again secure the vote and, through legal means and persuasive articulation of their worth, they will be enabled "to correct

147 Ibid, 152.

148 Ibid, 153.

149 Ibid, 153.

150 Ibid, 154.

151 Ibid, 36-37.

152 Ibid, 155-156. 
the many grievous wrongs under which we suffer." ${ }^{, 153}$ Belton reminds the Imperium, as Griggs reminds his black readership, that while some (such as Bernard) appeal to the sword, the race must "devote [their] attention to that mightier weapon, the pen." ${ }^{.154}$ This, Belton insists, "is the storm center. Let us carry this point." ${ }^{, 155}$ Here is Griggs's endorsement of his own theories of race reform, with an insistence that rational, persuasive use of language will help bring about needed change, without the need to draw swords and indulge irrational passions.

It is exactly the concept of unchecked "passion" that Belton denounces in his speech, arguing that the Imperium must "leave out revenge" as "in His Holy Word our most high God has said: 'Vengeance is mine.' Great as is this Imperium, let it not mount God's throne and attempt by violence to rob Him of his prerogatives. In this battle we want Him on our side.,156 Here Griggs connects Belton's desire to imitate the "suffering Savior" of his youth with a rejection of violence. And Belton's outlook privileges a broader view of sacred history in which true Christians must submit, in an act of self-renunciation, to God's design. Further, Belton's rejection of violence echoes Dr. Lovejoy insistence that the "kingdom of God is within" and followers of Christ take "no thought to [their] own glory."

Finally, when Griggs titles the chapter of Belton's speech, "The Storm's Master," he signals a melding of the novel's Christ figure with his message of racial improvement through collective efficiency. When Belton concludes his speech, "the waves of the sea were now calm, the fierce winds had abated, there was a great rift in the dark clouds." ${ }^{158}$ Just as Christ spoke and calmed the turbulent waters, Belton is "at the helm" of his own righteous movement, his own

153 Ibid, 161.

154 Ibid, 164.

155 Ibid, 161.

156 Ibid, 161.

157 Ibid, 50.

158 Ibid, 165. 
historical and spiritual revolution. ${ }^{159}$ And like Christ, Belton must die for his revolutionary beliefs. In the novel's subsequent pages, then, Belton prepares for this sacrificial death-the death of a "traitor" to the Imperium, but as one who "loved the race to which [he] belonged and the flag that floated over [him]. ${ }^{, 160}$ In other words by maintaining loyalty to his people and his country, Belton was judged to be a traitor to the Imperium, much in the same way that Berl Trout is both a traitor and a patriot at the novel's opening. And Griggs asks readers just what kind of nation they, themselves, live in, when a man who followed the principles of self-denial, racial solidarity, and cooperation is executed as an enemy of the race. The cycle is complete: the chaos and instability of a white supremacist culture has permeated black citizens' efforts at race reform and those who should be unified have succeeded only in executing one of their own.

\section{Conclusion}

As we reach the end of Imperium Griggs unequivocally confronts us with the fact that just as there was no clear, tidy way for him to resolve the racial injustice of his time, there is no way for us to neatly resolve his portrayal of that racial injustice. He had grown up amid some of the sharpest controversies in the Baptist church and lived and moved in a society where racial divisions were deep and sanctioned by law and theology alike. In short, he is neither correctly labeled as a militant or accomodationist, and, instead, those of us who seek to understand him in context must press beyond such monikers to engage him as a nuanced thinker who saw the merit of strident social activism as well as practical, quieter means of reform. In the end, Griggs lived as a believer devoted to working out his own salvation and the salvation of his people through social Christianity. And at the core of his vision was a fidelity to the "printed page," which he 
believed could change the black community from the inside out.

In his role as minister-writer Griggs sought to distill Christological concepts of selfdenial and sacred history to his "congregation" of readers and he focused his efforts on the African-American community itself. Unlike the other writers in this study, Griggs did not continue to speak through fictional stories and anecdotes for his entire career-abandoning the novel form in favor of other, more direct genres. Many of his proposals of reform, which found root in Imperium, were ahead of his time, while as a man of his time some of the policies he endorsed seem to us apologetic and unprogressive. These identities we must hold in tension, much as he did in his own day. To that end perhaps we would do well, in our own study of this fraught period in American history, to submit to Griggs's instruction in Life's Demand's, where he reminds us: "While a man must have the courage to proclaim his own views, he must likewise keep an open mind, ready to accept the truth when it comes from another... We rarely know when we have reached the bottom of a thing."

161 Griggs, Life's Demands, 40. 


\section{Conclusion: Still Searching for the "Divine Spark"}

It seems fitting, and yet haunting, that as I composed this examination of late nineteenthcentury race reform, the nation's twenty-first-century racial tensions were garnering national headlines. Scenes of protests made their way into living rooms across the country, social media exploded with personal accounts of the demonstrations, and every news broadcast led with some discussion about or update on "Ferguson." What had begun as a local and personal tragedy in the St. Louis, Missouri, community — the shooting death of a young, black man by a young, white police officer - had erupted into a national conversation about persistent and systematic racial divisions, the criminal justice system, poverty, and the lack of opportunity in communities of color. The pitched debate and the marches continued, for weeks, then months - from Chicago to Oakland, and from Denver to Atlanta and Baltimore. Every few days tensions were reignited by news of yet another unarmed black citizen dying at the hands of police — an accumulation of violent deaths that included Eric Garner in New York City, Tamir Rice in Cleveland, Kaijeme Powell in St. Louis, Ezell Ford in Los Angeles, Rumain Brisbon in Phoenix, Freddie Gray in Baltimore, and on and on. There was a feeling of a cultural moment, a taking-of-account where systemic racial divisions could finally be confronted. But instead the discussion following Ferguson taught (and continues to teach) us that even in our twenty-first century American society, racial disparity is viewed as a series of ruptures - anomalies in an otherwise placid and democratic society. In short, race reform is still approached as "triage" rather than a sustained treatment of the historical and deeply engrained racial policies that have existed since black Americans were granted citizenship more than one hundred and fifty years ago.

In part, these existing racial tensions reveal a persistent reluctance to confront race with the nuance and care it deserves - primarily because, as a society, we are often incapable of 
discussing race beyond the bookend categories of slavery and Civil Rights. Just as instances of racial violence or inequity are treated as ruptures in the American landscape, race itself is viewed as an issue of concern only for marginalized individuals, a footnote to our larger historical narrative. To enlarge and correct this view, then, requires a careful historical examination of the ways in which race itself was made (and remade) in the public sphere, as a conscious effort to preserve white supremacist control in society.

For these reasons, a turn back to the literature of the late nineteenth-century, post-Civil War era is instructive-indeed crucial — in our current environment, as it lays bare the turbulent world African Americans entered in the early days of freedom, while simultaneously uncovering the systemic nature of racial inequality that is at the core of America's past. On the surface, slavery had been abolished at Appomattox, and the Reconstruction Amendments promised black citizens full protection and privileges under the Constitution. But the undercurrents of white supremacy were tenacious, insidious, and a few federal laws (even federal troops) were powerless to rid the nation of prejudice. By 1877 the federal government withdrew from the struggle, acknowledged Reconstruction as a failure, and the South was left in unprecedented chaos on a scale that is difficult for us, today, to comprehend. And yet the idea persists that America's racist transgressions ended with the Civil War - that the conflict atoned for a multitude of sins and prompted a new, glorious era of emancipation. In short, we still cling to the tidy categories of slavery and freedom, without acknowledging the chaos, mess, injustice, and conscious denial of rights, education, social space, employment, religious membership, and selfactualization imposed on African Americans in the era of "freedom."

Writers such as Twain, Sheldon, Harper, Griggs, and others like them wade into this turbulent past, and stand as a testament to those who strove to alter America's unjust and 
unchristian course. In many regards, their projects failed: American Christendom is still largely "segregated" on Sunday mornings and the "sham" of what Twain called "nominal" Christianity persists in a variety of social and legalistic restrictions touted by many Protestant denominations. A dramatic gulf persists between schools in communities of color and majority-white schools, violating Sheldon's educational vision and the racial uplift he hoped it would provide. Similarly, while Social Gospel reformers did adopt the institutional church model, the practice only lasted through the first few decades of the twentieth century and is all but invisible across Protestantism today. In other ways, however, Harper's and Griggs's aspirations for African-American social justice foreshadowed the efforts of the Civil Rights Movement, as Martin Luther King Jr.'s “beloved community" echoes Harper's powerful exhortations for the "black Nazareth." Indeed, King even referenced "Jesus of Nazareth" on several occasions, including his "I Have a Dream" speech when he remarked, "Let us be maladjusted as Jesus of Nazareth, who could look into the eyes of the men and women of his generation and cry out, 'Love your enemies. Bless them that curse you. Pray for them that spitefully use you."”' And of course, Griggs's cautionary depiction of black militancy — of vengeance unchecked — came to shocking fruition in the mid-twentieth century with violent, nationalist groups like the Black Panthers. Viewed in this continuum of American race relations, then, the writers of the late nineteenth century provide a missing but essential piece of America's racial past, to illustrate the efforts of reformers and to characterize the substantial and daunting challenges they faced at every turn.

The legacy of Christian Liberalist fiction also issues a challenge to common notions about America's literary past and how we teach American literature in our classrooms. Most American literature survey courses break at the 1865 mark, with the first "half" of the survey

1 Martin Luther King Jr., qtd. in Wolfgang Mieder, 192. Wolfgang Mieder, "Making a Way Out of No Way": Martin Luther King's Sermonic Proverbial Rhetoric. New York: Peter Lang Publishing, 2010. 
covering literature up to and including the Civil War, and with the second "half" focused on literature from 1865 to the present. But often the literature from 1865-1900 is passed over, and instructors begin with a gloss of Twain and move to discussions of W.E.B. DuBois and Booker T. Washington. A colleague once remarked that, in the second half of the survey, he likes to "skip to the good stuff," indicating that his survey started with twentieth-century fiction. In other words, in scholarship and in literary instruction, the late decades of the nineteenth century are regularly passed over, or characterized singularly as the start of beginning of American realism. But, as was illustrated in previous chapters, the decades from 1870-1900 were some of the most dramatic, chaotic, contested, and literarily productive years in America's past. These decades profoundly shaped the thinking and literary styles of the next century and yet, when I challenge students to name a writer from this time period, they are hard-pressed to name anyone other than Mark Twain. What I hope this study does is initiate considerations of other voices in the postbellum years - writers who were contesting white supremacist policy and practice, from a variety of backgrounds: Native American authors, Asian American authors, new immigrant writers, Jewish-American writers, Chicano American, Latino and Mexican American writers, Irish American authors. And I hope for a deeper and broader examination of the kinds of works we consider literature of the nineteenth century — from the burgeoning newspaper business in cities, to serial publications and popular literature, and to the vast publications of sermon texts and religious publications that reached a zenith in this era.

Finally, the writers in this study challenge our assumptions of a one-dimensional Protestant past, one in which antebellum, abolitionist Christian zeal was silenced with the guns at Appomattox, giving way to a placid landscape of postbellum secularism. Truthfully, after the War, "many of the Protestants who had once guided national life retreated from efforts at 
shaping society in order to cultivate private gardens of inward spiritual development.", And other Christians flocked toward the reunionist gospel that "denounced religious involvement in politics," and "accepted racial segregation."3 But there was also a brave and even radical cadre of believers who sought to transition Christianity into a practical, social message of racial inclusion and reform. They wrote in defense of African-American citizenship, they told the stark truth about racial violence even when no one wanted to listen, they interrogated the categorization of race, and they wrote as a sacred calling to insist that America live up to its ideals and the standards Christ set. It was frustrating and lonely labor at times, as evidenced by the private reflections of Twain, Harper, and Sheldon; and on the whole, their iteration of Christian theology did not revolutionize the American Church. Yet their work and faith practice laid an important foundation for twentieth century Civil Rights, and found new (if ironic) life in mid-twentieth century evangelicalism.

Today, Protestant writers have again gravitated toward this Christological message, and left-leaning congregations tout a gritty social gospel strikingly similar to Sheldon's "Christ for the common people." Progressive Christians on the margins are quietly fighting a battle for immigrant welfare, for African-American civil liberties, and for inclusion of gay and lesbian Christians, by folding in concepts of social justice with Jesus's practical message of love, discipleship, and self-sacrifice. Christian Liberalism has come full circle, then, as its focus on social injustice has found a new voice through writers like Brian McLaren, Rachel Held Evans, and Shane Claiborne, all of whom espouse an "emerging church" movement that takes root in an incarnational theology, questions traditional teachings of orthodoxy and Calvinism, and stresses the reformist principles of Jesus's gospel for the "least of these" in American society.

2 Noll, The Civil War as Theological Crisis, 53.

3 Blum, Reforging, 119. 
But while debates around Christianity and race continue in our time, the fictional renderings of social Christianity in the late nineteenth century have yet to find an equal. These works are flawed, conflicted, but still powerful attempts at communicating what Mark Twain eloquently called the "divine spark," of which he exclaimed, "How rich it makes us! It lifts us far above the other creatures \& confers upon us kinship with God... What a noble possession! The divine spark! ... Without it, we're poverty; with it, who can estimate our wealth?"4

4 Mark Twain qtd. in Bush, Mark Twain and the Spiritual Crisis of His Age, 269. 


\section{Bibliography:}

“1890 Kansas Federal Census,” Kansas State Historical Society. Topeka, KS. 2014.

Abbott, Lyman. "What Is Christianity?" The Arena 13 (Dec. 1890):36.

“A Practical Saviour.” Christian Index 65.52 (24 Dec. 1885). 8.

“Andover Theology.” Christian Union 34.18 (October 1886):28.

Andover Review. Vol. 18. Boston: Houghton, Mifflin \& Co., 1892. 649-650.

Andrews, Kenneth R. Nook Farm: Mark Twain's Hartford Circle. Cambridge: Harvard University Press, 1950.

Arner, Robert D. “Acts 17 and Huckleberry Finn: A Note on Silas Phelps' Sermon.” Mark Twain Journal 16.2(1972): 12.

“A Suffering Savior and a Suffering Race.” Baltimore Afro-American 10 Dec. 1898: 2.

Barnes, Howard A. Horace Bushnell and the Virtuous Republic. Metuchen, N.J.: Scarecrow, 1991.

Bastow, James Austin. "Nazareth" and "Nazarene." A Bible Dictionary: Being a Contemporary Digest of the History and Antiquities of the Hebrews and Neighboring Nations. London: Longman Brown, 1859.

Belmonte, Kevin. D.L. Moody. Nashville: Thomas Nelson, 2010.

Berkove, Lawrence I. “The Trickster God in Roughing It.” Thalia 18 (1998): 21-30.

------. and Joseph Csicsila. Heretical Fictions: Religion in the Literature of Mark Twain. Iowa City: University of Iowa, 2010.

Berends, Kurt. "'Thus Saith the Lord': The Use of the Bible by Southern Evangelicals in the Era of the American Civil War.” Dissertation. Oxford: Oxford UP, 1997.

Blum, Edward J. “'O God of a Godless Land': Northern African American Challenges to White 
Christian Nationhood, 1865-1906." Vale of Tears: New Essays on Religion and Reconstruction. Ed. Edward J. Blum and W. Scott Poole. Macon, GA: Mercer University, 2005.

------. Reforging the White Republic: Race, Religion, and American Nationalism, 1865-1898. Baton Rouge: Louisiana State UP, 2005.

Bone, Robert A. The Negro Novel in America. New Haven, CT: Yale University, 1965. Boyd, Melba Joyce. Discarded Legacy: Politics and Poetics in the Life of Frances E.W. Harper, 1825-1911. Detroit: Wayne State University, 1994.

Boyer, Paul. "In His Steps: A Reappraisal." American Quarterly 23.1 (Spring 1971):60-78.

Briggs, Charles A. "The One Flock of Christ.” Reformed Quarterly Review 3 (Jul 1896):302.

Briggs, Gabriel A. "Imperium In Imperio: Sutton E. Griggs and the New Negro of the South." Southern Quarterly 45.3 (Spring 2008):153-176.

Brodwin, Stanley. "Mark Twain's Theology: The Gods of a Brevet Presbyterian.” The Cambridge Companion to Mark Twain. Ed. Forrest G. Robinson. Cambridge: Cambridge UP, 1995. 220-48.

Brown, William Wells. "My Southern Home." 1880. From Fugitive Slave to Free Man: The Autobiographies of William Wells Brown. Columbia, MO: University of Missouri, 1993. Budd, Louis. Mark Twain: Social Philosopher. Bloomington: Indiana UP, 1962.

Burnidge, Cara L. "Charles M. Sheldon and the Heart of the Social Gospel Movement" (2009). Electronic Theses, Treatises and Dissertations. Paper 2731.

Bush, Harold. “'A Moralist in Disguise': Mark Twain and American Religion.” A Historical Guide to Mark Twain. Ed. Shelley Fisher Fishkin. Oxford: Oxford UP, 2002.

-----. Mark Twain and the Spiritual Crisis of His Age. Tuscaloosa: University of Alabama, 2007. 
Bushnell, Horace. Building Eras in Religion. New York: Charles Scribner's Sons, 1881.

God in Christ: Three Discourses. New York: Charles Scribner's Sons, 1876.

------. Pulpit Talent, Training for the Pulpit Manward, Building Eras in Religion, and Literary

Varieties. London: Folkard \& Sons, 1882.

Cameron, Andrew. "The Return to Nazareth." The Family Treasury of Sunday Reading. London: Thomas Nelson \& Sons, 1860.

Camfield, Gregg. "Mark Twain and Amiable Humor.” A Companion to Mark Twain. Ed. Peter Messent and Louis J. Budd. Malden, MA: Blackwell, 2005.

Cardwell, Guy. Twins of Genius. Michigan: Michigan State College Press, 1953.

Chakkalakal, Tess. "Reading in Sutton E. Griggs.” Ed. Tess Chakkalakal and Kenneth W. Warren. Jim Crow, Literature, and the Legacy of Sutton E. Griggs. Athens, GA: University of Georgia, 2013. 143-166.

-----. “Who Was Sutton Griggs?” Humanities Writ Large. Ed. Laura Eastwood and Robert Zimmerman. Duke University. 26 March 2012. Web. 20 Feb. 2015.

Chakkalakal, Tess and Kenneth W. Warren. "Introduction.” Ed. Tess Chakkalakal and Kenneth W. Warren. Jim Crow, Literature, and the Legacy of Sutton E. Griggs. Athens, GA: University of Georgia, 2013. 1-20.

Cheney, Howell. The List of Members of the Monday Evening Club, Together with the Record of Papers Read at Their Meetings, 1869-1954. Hartford: privately printed, 1954. Mark Twain Papers. University of California, Berkeley.

Chesnutt, Charles. “Charles W. Chesnutt's Own View of His Story The Marrow of Tradition. Cleveland World. 20 Oct. 1901.

Coleman, Finnie D. Sutton E. Griggs and the Struggle Against White Supremacy. Knoxville: 
University of Tennessee, 2007.

Corey, Charles H. A History of the Richmond Theological Seminary. Richmond, VA: J.W. Randolph Company, 1895.

Cox, Thomas C. Blacks in Topeka, 1865-1915. Baton Rouge: Louisiana State University, 1982.

Cummings, Sherwood. Mark Twain and Science: Adventures of a Mind. Baton Rouge: Louisiana State UP, 1988.

Curtis, Susan. A Consuming Faith: The Social Gospel and Modern American Culture. Columbia MO: University of Missouri, 2001.

Dawes, Anna L. “Jesus Christ's Method of Social Regeneration.” The Independent. 42.2187 (30. Oct. 1890):3

Dempsey, Terrell. Searching for Jim: Slavery in Sam Clemens's World. Columbia, MO: University of Missouri, 2003

DePalma, Michael-John, "Rhetorical Education for the Nineteenth Century Pulpit: Austin Phelps and the Influence of Christian Transcendentalism at Andover Theological Seminary." Rhetoric Review 31.1 (2012):1-20.

Devins, John Banoroft. "With the Author of 'In His Steps."” New York Observer and Chronicle. 77.29 (20 July 1899):69.

Dorrien, Gary. The Making of American Liberal Theology: Imagining Progressive Religion 1805-1900. Louisville: Westminster John Knox, 2001.

Douglass, Frederick. Narrative of the Life of Frederick Douglass, an American Slave. 1845. New York: Penguin, 1982.

Eberman, Clarence E. “A Sunday with Rev. Charles M. Sheldon.” Congregationalist and Christian World 87.6 (8 Feb. 1902):201. 
Elzey, Wayne. “'What Would Jesus Do?' In His Steps and The Moral Codes of the Middle Class.” Soundings 58.4 (Winter 1975): 463-489.

Ensor, Allison. “A Clergyman Recalls Hearing Mark Twain.” Mark Twain Journal 15.3 (197071): 6 .

------. Mark Twain and the Bible. Lexington: University of Kentucky, 1969.

Ernest, John. "From Mysteries to Histories: Cultural Pedagogies in Frances E. W. Harper's Iola Leroy." American Literature 64.3 (Sept. 1992):497-518.

------. “Harnessing the Niagara: Sutton E. Griggs's The Hindered Hand. Ed. Tess Chakkalakal and Kenneth W. Warren. Jim Crow, Literature, and the Legacy of Sutton E. Griggs. Athens, GA: University of Georgia, 2013. 186-213.

Eutsey, Dwayne. "Mark Twain's Attitudes toward Religion: Sympathy for the Devil, or Radical Christianity?" Religion and Literature 31 (1999): 45-64.

Ezell, Kaine. "Uncle Silas in Huck Finn: 'A Mighty Nice Old Man."' Mark Twain Annual (2011): 98-110.

Ferré, John P. A Social Gospel for Millions: The Religious Bestsellers of Charles Sheldon, Charles Gordon, and Harold Bell Wright. Bowling Green: Bowling Green State University, 1988

Fessenden, Tracy. Culture and Redemption: Religion, The Secular, and American Literature. Princeton: Princeton UP, 2007.

Finke, Roger and Rodney Stark. The Churching of America, 1776-1999: Winners and Losers in Our Religious Economy. New Brunswick, NJ: Rutgers UP, 1992.

Fischer, Victor and Lin Salamo. "Foreward." Adventures of Huckleberry Finn. Berkley: University of California, 2001. 
Fishkin, Shelley Fisher. Was Huck Black? Mark Twain and African-American Voices. New York: Oxford, 1993.

Fleming, Robert E. “Sutton E. Griggs: Militant Black Novelist.” Phylon 34.1 (1973): 73-77

Foster, Frances Smith, ed. A Brighter Coming Day: A Frances Ellen Watkins Harper Reader. Ed. Frances Smith Foster. New York: City University of New York, 1990.

-----. "Gender, Genre and Vulgar Secularism: The Case of Frances Ellen Watkins Harper and the AME Press.” Recovered Writers/Recovered Texts. Ed. Dolan Hubbard. Knoxville, TN:University of Tennessee, 1997. 46-59.

Fulton, Joe B. The Reverend Mark Twain: Theological Burlesque, Form, and Content. Columbus: The Ohio State University, 2006.

Furness, William Henry. A History of Jesus. Boston: Crosby, Nichols \& Company, 1853.

-----. “Jesus of Nazareth.” The Unitarian Review 32.1 (July 1889):47.

Geismar, Maxwell. Mark Twain: An American Prophet. Boston: Hougton Mifflin, 1970.

Geismar, Maxwell. Ed. Mark Twain and the Three Rs: Race, Religion, Revolution-and Related Matters. Indianapolis: Bobbs-Merrill, 1973.

Geffen, Elizabeth May. Philadelphia Unitarianism, 1796-1861. Philadelphia: University of Pennsylvania, 1961.

Goldberg, David Theo. Racist Culture: Philosophy and the Politics of Meaning. Cambridge: Blackwell, 1993.

Glaude, Eddie S. Exodus! Religion, Race, and Nation in Early Nineteenth-Century Black America. Chicago:University of Chicago, 2000.

Gloster, Hugh. "Sutton E. Griggs: Novelist of the New Negro.” Phylon 4.4 (1943):335-345.

Graham, William C. Half Finished Heaven: The Social Gospel in American Literature. Lanham, 
Maryland: University Press of America, 1995.

Griggs, Sutton E. Cooperative Natures and Social Education: A Philosophy of Civic Life.

Memphis, TN: National Public Welfare League, 1929.

-----. Imperium In Imperio. 1899. New York: Modern Library, 2003.

-----. Kingdom Builder's Manual, Companion Book to Guide to Racial Greatness. Memphis, TN:

National Public Welfare League, 1924.

-----. Life's Demands; or, According to Law. Memphis, TN: National Public Welfare League, 1916.

-----. Light on Racial Issues. Memphis, TN: National Public Welfare League, 1921.

-----. Paths of Progress; or, Co-operation Between the Races, A Series of Addresses, Articles, and Essays. Memphis: National Public Welfare League, 1925.

-----. The Story of My Struggles. Memphis, TN: The National Public Welfare League, 1914.

Gross, Ariela. What Blood Won't Tell: A History of Race On Trial in America. Cambridge, MA: Harvard, 2008.

Harnsberger, Caroline. Mark Twain's Views of Religion. Evanston, Ill: Schori, 1961.

Harper, Frances E. W. “A Factor in Human Progress.” 1885. A Brighter Coming Day: A Frances Ellen Watkins Harper Reader. Ed. Frances Smith Foster. New York: City University of New York, 1990.

-----. “Colored People of America." 1857. A Brighter Coming Day: A Frances Ellen Watkins Harper Reader. Ed. Frances Smith Foster. New York: City University of New York, 1990

-----. “Coloured Women of America.” 1878. A Brighter Coming Day: A Frances Ellen Watkins Harper Reader. Ed. Frances Smith Foster. New York: City University of New York, 
1990.

----. “Count on Me as a Subscriber." 1903(?). A Brighter Coming Day: A Frances Ellen Watkins Harper Reader. Ed. Frances Smith Foster. New York: City University of New York, 1990.

-----. "Enlightened Motherhood.” 1892. A Brighter Coming Day: A Frances Ellen Watkins Harper Reader. Ed. Frances Smith Foster. New York: City University of New York, 1990.

-----. "Here Is Ignorance to Be Instructed.”1870. A Brighter Coming Day: A Frances Ellen Watkins Harper Reader. Ed. Frances Smith Foster. New York: City University of New York, 1990.

-----. “The Great Problem to Be Solved.” 1875. A Brighter Coming Day: A Frances Ellen Watkins Harper Reader. Ed. Frances Smith Foster. New York: City University of New York, 1990.

-----. “Simon's Countryman.” 1893. A Brighter Coming Day: A Frances Ellen Watkins Harper Reader. Ed. Frances Smith Foster. New York: City University of New York, 1990.

-----. Iola Leroy, or, Shadows Uplifted. 1893. Mineola, N.Y.: Dover, 2010.

-----. “The Triumph of Freedom-A Dream.” 1860. A Brighter Coming Day: A Frances Ellen Watkins Harper Reader. Ed. Frances Smith Foster. New York: City University of New York, 1990.

-----. "Then and Now. 1895. A Brighter Coming Day: A Frances Ellen Watkins Harper Reader. Ed. Frances Smith Foster. New York: City University of New York, 1990.

-----. “To John Brown.” 1859. A Brighter Coming Day: A Frances Ellen Watkins Harper Reader. Ed. Frances Smith Foster. New York: City University of New York, 1990. 
----. "To Mary Brown.” 1859. A Brighter Coming Day: A Frances Ellen Watkins Harper Reader. Ed. Frances Smith Foster. New York: City University of New York, 1990.

-----. "True and False Politeness." 1898. A Brighter Coming Day: A Frances Ellen Watkins Harper Reader. Ed. Frances Smith Foster. New York: City University of New York, 1990.

----. "We Are All Bound up Together." 1866. A Brighter Coming Day: A Frances Ellen Watkins Harper Reader. Ed. Frances Smith Foster. New York: City University of New York, 1990.

----- "The Woman's Christian Temperance Union." 1888. A Brighter Coming Day: A Frances Ellen Watkins Harper Reader. Ed. Frances Smith Foster. New York: City University of New York, 1990.

Harris, George. The Rational and Spiritual Verification of Christian Doctrine. Andover: Warren F. Draper, 1883.

Harvey, Paul. Freedom's Coming: Religious Culture and the Shaping of the South from the Civil War through the Civil Rights Era. Chapel Hill: University of North Carolina, 2005.

-----. Redeeming the South: Religious Cultures and Radical Identities Among Southern Baptists, 1865-1925. Chapel Hill: University of North Carolina, 1997.

Hawn, C. Michael. "History of Hymns: 'I Love to Tell the Story,"” United Methodist Church Discipleship Ministries. Web. 2015.

Heidegger, Martin. Being and Time: A Translation of Sein und Zeit. Albany: State University of New York Press, 1996.

Herron, George. "The Great Oration.” Wealth Makers. 21 June 1894. 1-8.

Higginbotham, Evelyn Brooks. Rightteous Discontent: The Woman's Movement in the Black 
Baptist Church, 1880-1920. Cambridge: Harvard, 1993.

Hill, Hamlin Lewis. Mark Twain: God's Fool. New York: Harper \& Row, 1973.

Hill, Patty Smith. History and Theory of Early Childhood Education. Samuel J. Braun and Esther P. Edwards, Eds. Belmont, CA: Wadsworth, 1972.

Holifield, E. Brooks. Theology in American: Christian Thought from the Age of the Puritans to the Civil War. New Haven: Yale UP, 2003.

Hopkins, Charles Howard. The Rise of the Social Gospel in American Protestantism, 1865-1915. New Haven: Yale, 1940.

Hughes, Langston. “A New Song.” The Collective Works of Langston Hughes: The Poems 19211940. Ed. Arnold Rampersad. Columbia, MO: University of Missouri, 2001. 144-145.

Hurston, Zora Neale. "How It Feels to Be Colored Me." I Love Myself When I Am Laughing. Ed. Alice Walker. New York: City University of New York, 1979.

Jackson, Cassandra. 'II Will Gladly Share With Them My Richer Heritage': Schoolteachers in Frances E.W. Harper's Iola Leroy and Charles Chesnutt's Mandy Oxendine.” African American Review 37.4 (2003):553-568.

Jackson, Gregory S. The Word and Its Witness: The Spiritualization of American Realism. Chicago: University of Chicago, 2009.

Jenkins, Thomas E. The Character of God: Recovering the Lost Literary Power of American Protestantism. New York: Oxford UP, 1997.

“Jesus Passing.” Hymnary. The Hymn Society of the United States and Canada. 2014. Web. Johnson, Lynn R. "A Return to the Black (W)hole: Mitigating the Trauma of Homelessness in Sutton E. Griggs's Imperium in Imperio. The Southern Literary Journal 42.2 (Spring 2010):12-33. 
Julian, John. A Dictionary of Hymnology. London: John Murray, 1892.

Karafilis, Maria. “Oratory, Embodiment, and U.S. Citizenship in Sutton E. Griggs's Imperium in Imperio “ African American Review 40.1 (2006): 125-143.

Knadler, Stephen. "Sensationalizing Patriotism: Sutton Griggs and the Sentimental Nationalism of Citizen Tom.” American Literature 79.4 (December 2007):673-699.

Lamon, Lester C. Black Tennesseans, 1900-1930. Knoxville, TN: University of Tennessee, 1977.

Levander, Caroline. "Sutton Griggs and the Borderlands of Empire," American Literary History 22.1 (2009):57-84.

Lewis, C.S. "Footnote to All Prayers." The Cambridge Companion to C.S. Lewis. Ed. Robert MacSwain and Michael Ward. New York: Cambridge University Press, 2010.

Lewis, Leslie W. "Biracial Promise and the New South in Minnie's Sacrifice: A Protocol for Reading The Curse of Caste; or, The Slave Bride. African American Review 40.4 (2006):755-767.

Locke, Alain LeRoy. The New Negro. New York: Touchstone, 1925.

Lott, Eric. "Mr. Clemens and Jim Crow: Twain, Race, and Blackface.” The Cambridge Companion to Mark Twain, ed. Forrest G. Robinson, 129-152. Cambridge: Cambridge UP, 1995.

Lowance Jr., Mason I., ed. A House Divided: The Antebellum Slavery Debates in America, 17761865. Princeton, N.J.: Princeton UP, 2003.

Luker, Ralph E. The Social Gospel in Black and White: American Racial Reform 1885-1912. Chapel Hill: University of North Carolina, 1991.

May, Joseph. “Address By Dr. Joseph May.” Friends' Intelligencer 56.19 (13 May 1899):374. 
-----. "The Method of Revelation.” The Radical (Feb. 1869):107

Mathews, Shailer. "Social Gospel." A Dictionary of Religion and Ethics. Ed. Shailer Mathews and Gerald Birney Smith. New York: Macmillan, 1921.

McConnell, Judith. "Kindergarten in Kansas: A View From the Beginning." Journal of Education 177.3 (1995):9-22.

McLoughlin, William G. Revivals, Awakenings, and Reform: An Essay on Religion and Social Change in America, 1607-1977. Chicago: Univeristy of Chicago, 1978.

Messent, Peter. "Mark Twain, Joseph Twichell, and Religion.” Nineteenth-Century Literature 58.3 (Dec. 2003): 368-402.

Mieder, Wolfgang. "Making a Way Out of No Way": Martin Luther King's Sermonic Proverbial Rhetoric. New York: Peter Lang Publishing, 2010.

Miller, Timothy. Following in His Steps: A Biography of Charles M. Sheldon. Knoxville: University of Tennessee, 1987.

Mills, Charles. The Racial Contract. Ithaca: Cornell University, 1997.

Mizruchi, Susan L. The Science of Sacrifice: American Literature and Modern Social Theory. Princeton: Princeton University, 1998. 26.

Montgomery, William E. Under Their Own Vine and Fig Tree: The African-American Church in the South, 1865-1900. Baton Rouge, LA: Louisiana State University, 1993.

Moody, Dwight L. Glad Tidings: Comprising Sermons and Prayer-Meeting Talks Delivered at the N.Y. Hippodrome. New York: E.B. Treat, 1876.

Moore, Jacqueine M. Leading the Race: The Transformation of the Black Elite in the Nation's Capital. Charlottesville, VA: University of Virginia, 1999.

Morris, Elias Camp. "President's Annual Address at the National Baptist Convention, 
Kansas City, Missouri.” Sept. 1898. Keynote Address. Sermons, Addresses and Reminiscences and Important Correspondence. National Baptist Publishing Board: Nashville, 1901. 78-92.

-----. "President's Annual Address at the National Baptist Convention, Nashville, Tennessee." Sept. 1899. Keynote Address. Sermons, Addresses and Reminiscences and Important Correspondence. National Baptist Publishing Board: Nashville, 1901. 93-108.

Moses, Wilson Jeremiah. The Golden Age of Black Nationalism, 1850-1925. New York: Oxford, 1978.

“Mr. Sheldon’s Eight Months' Campaign.” Congregationalist 85.52 (29 Dec. 1900):967.

Munger, Theodore T. Horace Bushnell: Preacher and Theologian. Boston: Houghton, Mifflin \& Co., 1899.

Neider, Charles, ed. “Mark Twain: Reflections on Religion.” Hudson Review 16 (1963): 329-52.

Noll, Mark A. America's God: From Jonathan Edwards to Abraham Lincoln. Oxford: Oxford UP, 2002.

-----. The Civil War as Theological Crisis. Chapel Hill: University of North Carolina, 2006.

-----. God and Race in American Politics: A Short History. Princeton: Princeton UP, 2008.

-----. A History of Christianity in the United States and Canada. Grand Rapids: William B. Eerdmans, 1992.

-----. The Work We Have to Do: The History of Protestants in America. New York: Oxford University, 2000.

Novak, Terry D. "Frances Harper's Poverty Relief Mission in the African American Community." Our Sister's Keepers (2005):213-226.

Nowatzki, Robert C. "Miscegenation and the Rhetoric of Blood in Three Turn-of-the-Century 
African-American Novels." Journal of Contemporary Thought 6 (1996):41-50.

------. “'Sublime Patriots': Black Masculinity in Three African-American Novels." Journal of Men's Studies 8.1 (Fall 1999):59.

O'Connor, Flannery. The Correspondence of Flannery O'Connor and the Brainard Cheneys. Ed. C. Ralph Stephens. Jackson, MS, 1986.

“Our Legacy.” First Unitarian Church of Philadelphia. 2014. Web.

Paine, Albert Bigelow. Mark Twain: A Biography. Vol IV. New York: Harper Bros., 1912.

Peterson, Carla L. Doers of the Word: African-American Women Speakers and Writers in the North (1830-1880). New Brunswick: Rutgers, 1995.

-----. "Frances Harper, Charlotte Forten, and African-American Literary Reconstruction." Challenging Boundaries: Gender and Periodization. Eds. Joyce W. Warren and Margaret Dickie. Athens, GA:University of Georgia, 2000. 39-61.

-----. "Further Liftings of the Veil: Gender, Class, and Labor in Frances E. W. Harper's Iola Leroy." Listening (1994):97-112.

Pinn, Anthony B. Making the Gospel Plain: The Writings of Bishop Reverdy Ransom. Harrisburg, PA: Trinity Press International, 1999.

-----. Embodiment and the New Shape of Black Theological Thought. New York: New York University, 2010.

Rauschenbusch, Walter. "The New Apostolate.” The Social Gospel in America: 1870-1920. Ed. Robert T. Handy. Oxford: Oxford UP, 1966. 331-332. Rauschenbusch's Christianity and the Social Crisis was published in 1907.

Reid, Daniel G., Robert D. Linder, Bruce L. Shelley, and Harry S. Stout, eds. The Dictionary of Christianity in America. Downer's Grove, Ill: InterVarsity, 1990. 
“The Rev. C. C. Gillespie at Camp Chase," Army and Navy Messenger for the Trans-Mississippi Department. 2 March 1865, 1.

“Rev. Charles M. Sheldon.” James L. King, Ed. History is of Shawnee County, Kansas, and Representative Citizens. Chicago: Richmond \& Arnold, 1905

“The Rev. William Henry Furness.” Outlook 51.2 (12 Jan. 1895):51.

Reynolds, David S. "From Doctrine to Narrative: The Rise of Pulpit Storytelling in America." American Quarterly 32.5 (1980): 479-498.

Ripley, John W. "The Strange Story of Charles M. Sheldon's In His Steps.” The Kansas Historical Quarterly 34.3 (Autumn 1968):241-265.

Roberts, Wendy Miller. "In His Steps in the Context of Regionalist Fiction.” Rocky Mountain Review of Language and Literature 61.2 (2007):44-53.

Robinson, Forrest G. “The Silences in Huckleberry Finn.” Nineteenth-Century Fiction 37.1(1982): 50-74.

Robison, Lori. “An 'Imperceptible Infusion' of Blood: Iola Leroy, Racial Identity, and Sentimental Discourse." Genre 37 (Fall/Winter 2004): 433-460.

Rutkowski, Alice. "Leaving the Good Mother: Frances E.W. Harper, Lydia Maria Child, and the Literary Politics of Reconstruction.” Legacy 25.1 (2008):83-104.

Sanborn, Geoffrey. "Mother's Milk: Frances Harper and the Circulation of Blood." ELH 72.3 (Fall 2005):691-715.

San Francisco Evening Bulletin. 14 March 1885. University of Virginia. http://twain.lib. virginia.edu

Sheldon, Charles M. “A Local Negro Problem.” The Kingdom 8 (10 Apr. 1896): 828.

-----. “A Social Experiment.” New York Observer and Chronicle 75.38 (Aug. 1900): 260. 
----- In His Steps: What Would Jesus Do? 1896. Uhrichsville, OH: Barbour Publishing, 2005.

-----. "Introduction,” The Redemption of Freetown. 1898. Celebration, FL: Kincaid Books, 2014.

----. “The Law of Christian Discipleship.” Zion’s Herald 76.9 (2 March 1898):265.

----. "Practical Sociological Studies." The Andover Review 14.82 (Oct. 1890):369.

-----. The Redemption of Freetown. 1898. Celebration, FL: Kincaid Books, 2014.

Shepherd, Allen. "The Social Gospel According to Charles Sheldon: In His Steps." The Markham Review 10 (1980/81):1-4.

Smith, Gary Scott. The Search for Social Salvation: Social Christianity and America, 1880-1925. Lexington: Lexington Books, 2000.

Smith, Mark M. How Race is Made: Slavery, Segregation, and the Senses. Chapel Hill: University of North Carolina, 2006.

Stancliff, Michael. Frances Ellen Watkins Harper: African American Reform Rhetoric and the Rise of a Modern Nation State. New York: Routledge, 2011.

Still, William. "Introduction.” Iola Leroy, or, Shadows Uplifted. 1893. Mineola, N.Y.: Dover, 2010.

-----. The Underground Railroad. Philadelphia: Porter and Coates, 1872

Stokes, Claudia. "The Religious Novel," The Oxford History of the Novel in English: The American Novel, 1870-1940. Ed. Priscilla Wald and Michael A. Elliott. Vol. 6. Oxford: Oxford U.P., 2014. 168-184.

Stowe, Harriet Beecher. My Wife and I. 1871. New York: Riverside, 1967.

Tal, Kali. “This Just Kills Me.” Social Text 20.2 (Summer 2002):65-91.

Torbett, David. "Horace Bushnell and 'Distinctions of Color': Interpreting an Ambivalent Essay on Race." Prism 14.2 (1999): 3-24. 
Tracy, Steven C. "Saving the Day: The Recordings of the Reverent Sutton E. Griggs." Phylon 47.2 (1986):159-166.

Twain, Mark. Adventures of Huckleberry Finn. 1884. Berkley: University of California, 2001.

------. "The Indignity Put Upon the Remains of George Holland by the Rev. Mr. Sabine.” What is Man? And other Philosophical Writings. 1871. Berkley: University of California, 1963. 53,51 .

-----. Mark Twain's Notebooks and Journals, vol. 4. Ed. Frederick Anderson. Berkeley: University of California Press, 1979.

------. “Only a Nigger.” The Buffalo Express. 26 Aug. 1869.

------. Samuel Langhorn Clemens to Orion and Mary E. (Mollie) Clemens, 19 and 20 Oct 1865, San Francisco, Calif. (UCCL 00092). Mark Twain Project Online. Berkeley, University of California Press. 2014.

------. Samuel Langhorn Clemens to Olivia L. Langdon, 27 Dec 1868, Tecumseh, Mich. (UCCL 00211). Mark Twain Project Online. Berkeley, University of California Press. 2014.

-------. "Samuel Langhorn Clemens to OLC, 29 December 1884, Pittsburgh, Pa. (UCCL 03077)." Mark Twain Project Online. Berkeley, University of California Press. 2014.

U.S. Congress. House of Representatives. 16 June 1993. $100^{\text {th }}$ Anniversary of the First Black Kindergarten West of the Mississippi River. $103^{\text {rd }}$ United States Congress. H3694H3695.

Veselá, Pavla. "Neither Black Nor White: The Critical Utopias of Sutton E. Griggs and George S. Schuyler.” Science Fiction Studies 38 (2011):270-287.

“Was Mark Twain a Racist?” University of Virginia, last modified April 4, 1997. http://www.virginia.edu. 
Walker, Randolph Meade. The Metamorphosis of Sutton E. Griggs: The Transition from Black Radical to Conservative, 1913-1933. Memphis: Walker Publishing, 1991.

Walvoord, Jr., John F. and Roy B. Zuck, eds. The Bible Knowledge Commentary. Vol. 2. Colorado Springs: Dave Cook, 1983.

Washington, James Melvin. Frustrated Fellowship: The Black Baptist Quest for Social Power. Macon, GA: Mercer University, 1986.

Weber, A.S. “Jesus Christ, the Greatest Reformer.” Reformed Quarterly Review. 3 (July 1892):389.

White Jr., Ronald C. Liberty and Justice for All: Race Reform and the Social Gospel, 1877-1925. Louisville: Westminster John Knox, 1990.

White Jr., Ronald C. and C. Howard Hopkins. The Social Gospel: Religion and Reform in Changing America. Philadelphia: Temple University, 1976.

Whitlow, Roger. "The Revolutionary Black Novels of Martin R. Delany and Sutton Griggs." MELUS 5.3 (Autumn 1978):26-36.

Williams, Delores S. Sisters in the Wilderness: The Challenge of Womanist God-Talk. Maryknoll, N.Y.: Orbis, 1993.

Weisberger, Bernard A. They Gathered at the River: The Story of the Great Revivalists and Their Impact Upon Religion in America. Chicago: Quadrangle, 1958.

Wright, Robert Glenn. The Social Christian Novel. New York: Greenwood Press, 1989.

Young, Elizabeth. "Warring Fictions in Iola Leroy.” American Literature 64.2 (June 1992):273297. 